\title{
Terrains of Struggle
}

The Finnish Forest Industry Cluster and

Corporate Community Responsibility to Indigenous Peoples in Brazil
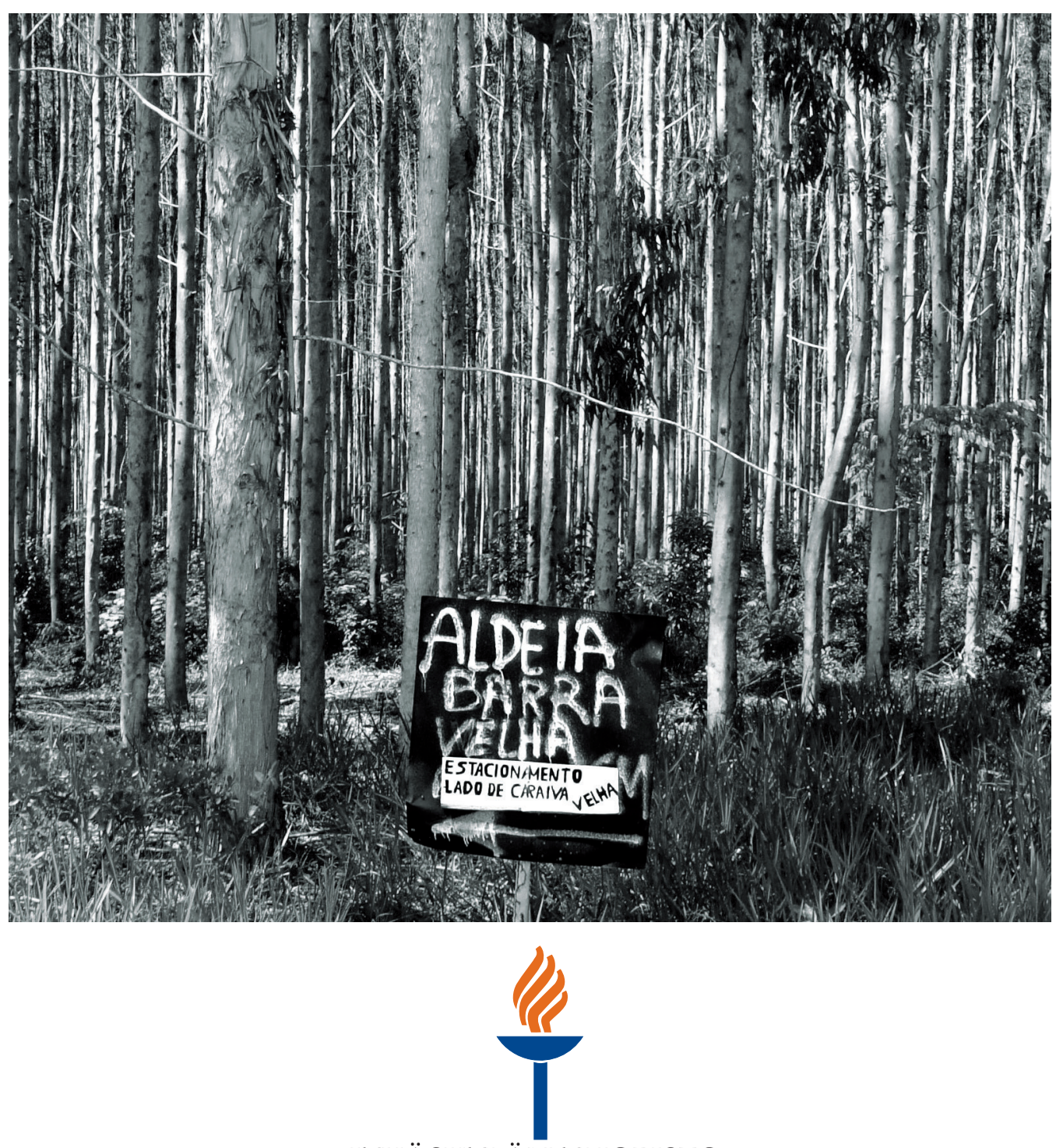


\section{Susanna Myllylä}

\section{Terrains of Struggle \\ The Finnish Forest Industry Cluster and Corporate Community Responsibility to Indigenous Peoples in Brazil}

Esitetään Jyväskylän yliopiston kauppakorkeakoulun suostumuksella julkisesti tarkastettavaksi yliopiston Agora-rakennuksen Gamma-salissa, elokuun 28. päivänä 2015 kello 12.

Academic dissertation to be publicly discussed, by permission of the Jyväskylä University School of Business and Economics, in building Agora, Gamma-hall on August 28, 2015 at 12 o' clock noon.

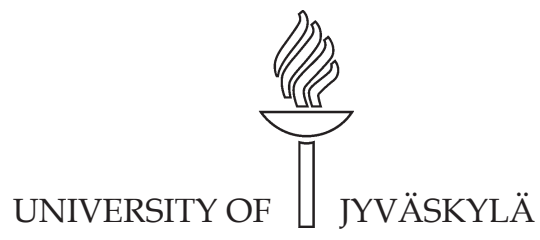

JYVÄSKYLÄ 2015 


\section{Terrains of Struggle}

The Finnish Forest Industry Cluster and Corporate Community Responsibility to Indigenous Peoples in Brazil 


\section{Susanna Myllylä}

\section{Terrains of Struggle}

The Finnish Forest Industry Cluster and Corporate Community Responsibility to Indigenous Peoples in Brazil

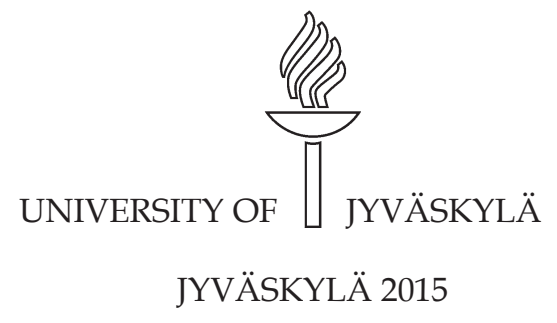


Editors

Tuomo Takala

Jyväskylä University School of Business and Economics

Pekka Olsbo, Sini Tuikka

Publishing Unit, University Library of Jyväskylä

Cover picture: In search of aldeia Barra Velha / Photo: Susanna Myllylä

(C) Photos Susanna Myllylä (except Images 3 and 5)

C Maps Susanna Myllylä and Aliisa Priha (except Map 2)

URN:ISBN:978-951-39-6266-1

ISBN 978-951-39-6266-1(PDF)

ISBN 978-951-39-6265-4 (nid.)

ISSN 1457-1986

Copyright (C 2015, by University of Jyväskylä

Jyväskylä University Printing House, Jyväskylä 2015 


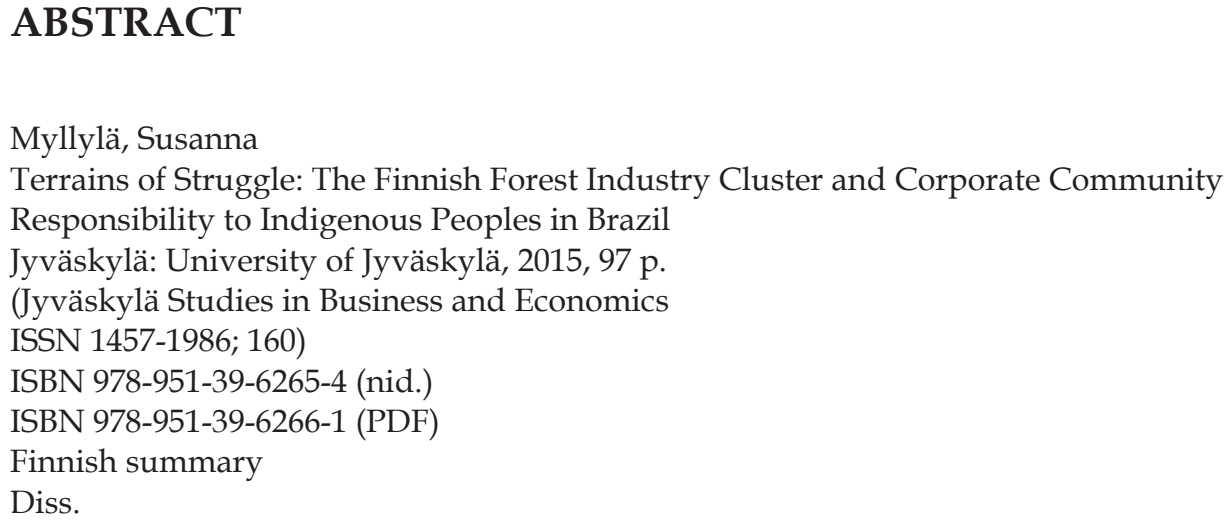

This multidisciplinary dissertation examines how the Finnish forest industry cluster has fulfilled its corporate community responsibility (CCR) on Brazil's Atlantic coast with regard to Indigenous stakeholders. Hence the objective is to study what local communities see as significant in CCR. The dissertation consists of an introduction and three articles published in peer-reviewed academic journals. The Finnish forest industry cluster is well established in Brazil: The Swedish-Finnish Stora Enso and the Brazilian Fibria Celulose (formerly Aracruz Celulose) each own 50 percent of their joint corporation, Veracel Celulose in Bahia state. In addition, consultants such as Pöyry, and Metso, which supplies machines and equipment, are involved. The Finnish firms operating in the pulp and paper industry have been entangled to various degrees in the land struggles of the Tupinikim, the Guaraní, and the Pataxó. The firms have taken advantage of delays in registration of Indigenous Territories in their entirety caused by the state's inefficiency. The research approach is based on knowledge derived from the grassroots rather than starting from the usual top-down perspective. A qualitative research methodology was used, combining case study with the Grounded Theory and field ethnography approaches. A long-term fieldwork was conducted in Brazil, including interviews with multiple actors. Collecting microhistories, "rays from the past," offers an alternative narrative not only on economic development in Brazil but also on the success stories of the Finnish firms in South America. The case studies were contextualized in Brazilian political economy and Indigenous rights frameworks. Through the prism of the national and international human rights system governing CCR, the performance of the Finnish companies was assessed. Based on the research findings, the study contends that the Finnish forest industry cluster has largely failed to recognize and perform in alignment with a regulatory framework extensively protecting Indigenous rights. The corporate community responsibility has focused on mere philanthropy, which has divided the Pataxó and hence weakened their territorial claims. In order to shift away from the Northern ethos in CCR discourses, the main result of the study is the generation of a "Concentric CCR Roadmap Model" for analyzing and guiding corporate community interaction in the South. Finally, the study introduces the contemporary Latin American development discourses and points the way toward finding other alternative conceptualizations for corporate stakeholder research in the global South contexts.

Keywords: Business ethics, corporate social responsibility, stakeholder, community, legitimacy, multinational corporation, Stora Enso, Veracel, Fibria, Indigenous Peoples, Brazil, Finland 
$\begin{array}{ll}\text { Author's address } & \begin{array}{l}\text { Susanna Myllylä } \\ \text { susanna.b.myllyla@jyu.fi }\end{array}\end{array}$

Supervisors Tuomo Takala

School of Business and Economics

University of Jyväskylä

Reviewers

Adjunct Professor Tarja Ketola

University of Turku

Docent Simo Laakkonen

University Consortium of Pori

Opponents Adjunct Professor Tarja Ketola

University of Turku 


\section{ACKNOWLEDGEMENTS}

As an academic nomad, I would like to thank my supervisor, Professor Tuomo Takala, for encouraging me to conduct this multidisciplinary research project, and for our discussions and co-operation in the corporate legitimation research. I am grateful to Adjunct Professor Tarja Ketola and Docent Simo Laakkonen for their thorough evaluation of this study. Thanks to their insightful and frank comments, I was able to strengthen the description of the research setting and to contextualize my case studies more tightly within Brazilian society.

My fieldwork was facilitated by Brazilian anthropologists, namely Professor Maria Rosário Carvalho and her team in the Research Program on the Indigenous Peoples in Northeast Brazil, PINEB (Programa de Pesquisas sobre Povos Indígenas do Nordeste Brasileiro), part of the Department of Anthropology and Ethnology of the Federal University of Bahia (UFBA). I am grateful to Professor Carvalho, Dr. José Augusto Sampaio, and the researchers for our in-depth discussions in Salvador. Moreover, meeting with the multidisciplinary research group in Vitória, especially Dr. Celeste Ciccarone and Dr. Sandro José da Silva of the Federal University of Espírito Santo (UFES), provided valuable viewpoints on the land struggles.

Dr. Clayton Lino of the Atlantic Forest Biosphere Reserve, São Paulo, has illuminated for me the value of this endangered forest and its conservation policies. Various Brazilian non-governmental organizations, especially SOS Mata Atlântica Foundation and FASE, have offered important background information along the way.

Above all, I am grateful to the people of the Tupinikim, the Guaraní, and the Pataxó who shared their lifeworlds in order to enhance my research. We in the North surely have a lot to learn from their knowledges of Bem Viver - the good life.

My interpreters - Leena Nori from Penedo, and geographer Ligia Sancio from UFES - provided me with invaluable assistance and good company during the fieldwork. I would also like to acknowledge the Finnish-Brazilian group of ornithologists with whom I roamed the mountainous landscapes in the Atlantic Forest region.

Cartographer Aliisa Priha prepared the geographical maps, and working with her went very smoothly. I am glad for my long-term collaboration with copyeditor Chris Springer, who has vigorously proofread my texts, often within busy timetables. In addition, I would like to thank all other persons in Brazil and Finland who have offered me assistance and interesting discussions throughout this long-term research process. Any flaws in the dissertation are entirely my own responsibility.

My family and friends have unconditionally supported me throughout this process: loving thanks to Jyrki, my parents, Anne Pylvänäinen, Hannetuuli Voutilainen, Mirja Airos, Kaisa Pennanen, and many others.

Finally, I would like to thank the funding institutions: the Jenny and Antti Wihuri Foundation, the Jyväskylä Kauppalaisseura Foundation, and the Jyväskylä University School of Business and Economics.

Tampere, August 2015

Susanna Myllylä 


\section{TABLES}

TABLE 1 The Chapter on Indigenous Rights in the Brazilian Constitution ......27

TABLE 2 Fundamental principles of Indigenous Peoples' rights according to UNDRIP and ILO Convention No. 169 29

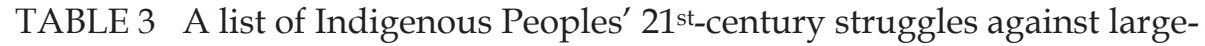
scale industrial and infrastructure projects in South America.

TABLE 4 The Ruggie Guiding Principles (GPs) for corporate-Indigenous relations

\section{IMAGES}

IMAGE 1 Jungle in the Paraíba do Sul river margins by Jean-Babtiste

Debret, 1834-1839

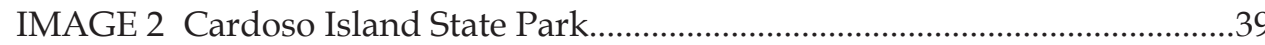

IMAGE 3 Veracel Biomaterials Business Area .........................................................43

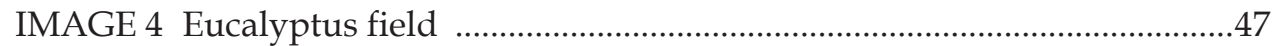

IMAGE 5 Veracel Biomaterials Business Area and a rainforest ..........................47

IMAGE 6 A young Pataxó introducing the aldeia .....................................................56

IMAGE 7 Landscape in Bahia ..............................................................................61

IMAGE 8 The roadsign by Veracel forbidding hunting and fishing ....................76

\section{MAPS}

MAP 1 Regions of Brazil .........................................................................19

MAP 2 A part of the large ethnic-historic map by Curt Nimuendajú,

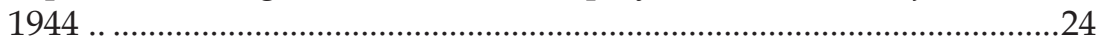

MAP 3 A map of Indigenous Peoples' 21st-century struggles against largescale industrial and infrastructure projects in South America ............33

MAP 4 Overlapping and competing functions in Ecuador's Yasuní Man and the Biosphere Reserve ..........................................................34

MAP 5 The original extent of the Atlantic Forest and the current remnants..... .37

MAP 6 Traces from the extractive industry: the Tupinikim village and the land structure in their territory .

MAP 7-8 The research sites in Bahia state and Espírito Santo state .....................52 


\title{
CONTENTS
}

\author{
ABSTRACT \\ ACKNOWLEDGEMENTS \\ TABLES, IMAGES, AND MAPS \\ CONTENTS \\ LIST OF ORIGINAL PUBLICATIONS
}

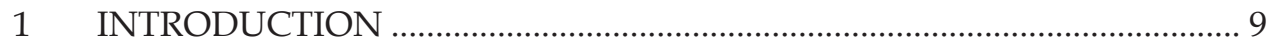

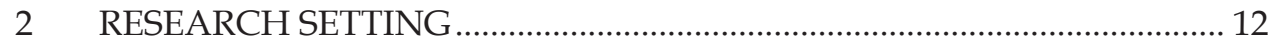

2.1 Theoretical foundations and gaps ................................................... 12

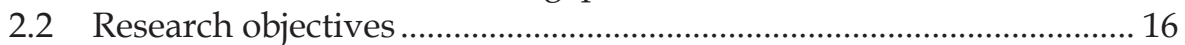

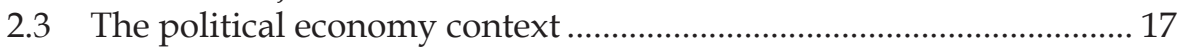

2.3.1 A route from colonialism to extractive capitalism ................... 17

2.3.2 The natives discovered ................................................................. 23

2.3.3 The contemporary human rights situation of the Indigenous

Peoples …….............................................................................. 25

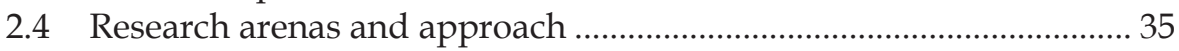

2.4.1 Pulp production in the Atlantic Forest domain.......................... 35

2.4.2 Getting in, getting on, getting out, and getting back ................ 48

3 THE RESEARCH ARTICLES AND THE MAIN FINDINGS ..................... 62

3.1 The rising collective and individual agency of the impacted

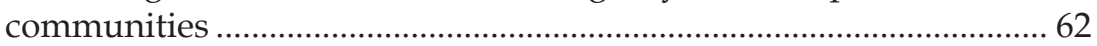

3.2 The subaltern communities resisting organizational hegemony...... 64

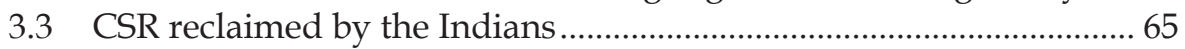

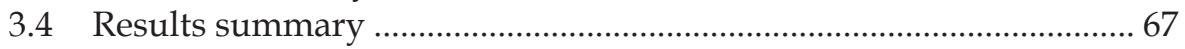

$4 \quad$ DISCUSSION AND CONCLUSIONS ........................................................... 71

4.1 The state, Indigenous rights, and corporations within the international regulatory framework ..................................................... 71

4.2 Latin American post-neoliberal alternatives to development............. 79

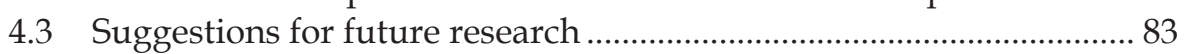

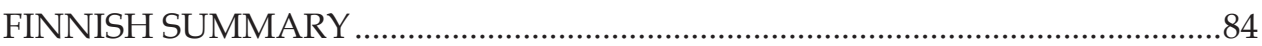

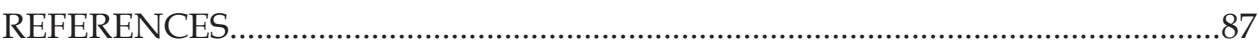

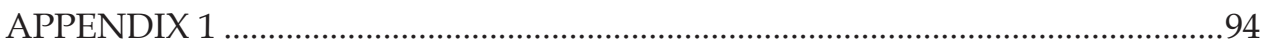

ORIGINAL PUBLICATIONS 


\section{LIST OF ORIGINAL PUBLICATIONS}

I Myllylä, S. 2010. Ethnoterritoriality confronting multinationals: Indigenous Peoples' Perceptions on Eucalyptus Plantation Industries in Atlantic Coastal Brazil. Arctic \& Antarctic: International Journal of Circumpolar Sociocultural Issues, Vol 4, No 4, 97-145.

II Myllylä, S. \& Takala, T. 2011. Leaking Legitimacies: The Finnish Forest Sector's Entanglement in the Land Conflicts of Atlantic Coastal Brazil. Social Responsibility Journal, Vol 7, No 1, 42-60

III* Myllylä, S. 2014. A Concentric CSR Roadmap Model for Host Community Relations in the Global South. EJBO-Electronic Journal of Business Ethics and Organization Studies, Vol 19, No 1, 27-51

* ERRATUM, EJBO Vol. 19, No. 1 (2014), p. 45, second paragraph:

ORIGINAL:

The Brazilian case study and the Indians' opinions, especially in territorial issues, reflect well on the Indigenous People's rights of ILO Convention No. 169 (see articles 25, 26, 29, and 40). This is also the case concerning the issue of self-determination, stated in the United Nations Declaration on the Rights of Indigenous Peoples (2008).

SHOULD READ:

The Brazilian case study and the Indians' opinions, especially in territorial issues, reflect well on the Indigenous People's rights of ILO Convention No. 169 (see articles 7, 13-19) and the United Nations Declaration on the Rights of Indigenous Peoples (see articles 25, 26, 29, and 40). This is also the case concerning the cross-cutting issue of self-determination. 


\section{INTRODUCTION}

Endless fields of gigantic eucalyptus plantations shadow both sides of Highway BR-101 alongside Brazil's Atlantic coast. BR-101 is a longitudinal highway, also called Translitorânea, crossing 12 Brazilian states and extending 4,800 kilometers. In 2004, Tupinikim and Guaraní Indians, accompanied by the members of the Landless Rural Workers Movement, Afro-Brazilian communities, and the Small Farmers' Movement, numbering 600 persons in all, blocked this highway in Espírito Santo state. Two years later, Pataxó Indians set up a road block in the neighboring northern state of Bahia. What has sparked these small-scale, hardly noticed social mobilizations, and moreover, why and how is Finland entangled with these distant incidents? Those questions came up during my travels along the Atlantic coast when doing fieldwork for my project on the governance of the Atlantic Forest Biosphere Reserve.

National and multinational corporations produce eucalyptus for their pulp and paper factories in coastal Brazil to be transported to the United States, Asia, and Europe, including to Stora Enso's factory in Oulu, Finland. The continuous growth logic of the Brazilian companies and multinational corporations (MNCs) on Brazil's Atlantic coast has faced a dual reception from various stakeholders or interest groups. The companies have been welcomed by the federal and state governments, municipalities, Brazilian firms, and wealthy landowners, and by skilled persons who could potentially have found employment in pulpwood production. On the other side, nature conservationists, landless rural peasants, Afro-Brazilian Quilombos, and a few municipalities consider eucalyptus monoculture a problematic phenomenon in the region. Last but not least, there are Indigenous Territories (ITs) of Brazilian Indians who are struggling for their ancestral lands. The cultures, lands, and livelihoods of the Brazilian Indians are broadly protected in national and international legislation; hence they possess specific and extensive land rights. However, the state has not fulfilled its obligations, and a large percentage of the ITs are still without official status. Hence the Indians have fought to defend their territorial land rights vis-á-vis local-, national-, and global-level actors, such as MNCs, all over the country, and especially in the frontier regions, namely Amazonia. Fur- 
thermore, even legal status does not guarantee full protection for the ITs, which are constantly invaded by the previous actors. This phenomenon is related to the wider societal picture: Brazil is a huge nation of over 200 million people and one of the world's leading economies. The country runs a strong developmentalist strategy based on extractive industries, urbanization, and massive infrastructure projects, many of which are situated in existing ITs, and nature reserves.

Translitorânea is no longer a mere transcoastal highway - it has become a locus of transcontinental and global processes. The Finnish firms regard Brazil as a country abundant in natural resources, including land, to be utilized. The environmental conditions are favorable, since eucalyptus can be harvested within just seven years. The Finnish forest industry cluster is well established in Brazil. The Swedish-Finnish Stora Enso and the Brazilian Fibria Celulose (formerly Aracruz Celulose) each own 50 percent of their joint corporation, Veracel Celulose in southernmost Bahia. In addition, consultants such as Pöyry, and Metso, which supplies machines and equipment, are involved. The investments are financed by public investment banks through export credits and other measures (see, e.g., Kröger, 2010, 129).

This study focuses on three Indigenous groups: the Tupinkim, the Guaraní, and the Pataxó, and their interaction with the Finnish forest industry cluster. The relationship between firms and local communities has become a growing field of research in business ethics and, concurrently, corporate social responsibility (CSR) discourses. Due in large part to pressure from civil society movements and international regimes promoting ethical business, corporations have had to take into account the external stakeholder aspect. Moreover, the Finnish forest industry cluster and its Brazilian business partner have acknowledged the stakeholder perspective when operating in an Atlantic coast region inhabited by traditional and other local communities. Stora Enso announced 1 :

Major stakeholder concerns in Brazil relate to land ownership and land use, landless and indigenous people's rights, the water use of plantations, and local social and development issues related to poverty. Our aim is to be an active member of local communities and help to address these challenges.

Besides claiming to be good corporate citizens at the local level, the companies, on their webpages, advocate commitment to sustainable development at the global level. Stora Enso's slogan is "Do Good for the People and the Planet," while Fibria has a green leaf in its logo and is committed "to the future and to the vitality of this earth of ours". Veracel "intends to become the worldwide benchmark in sustainability" and distinguish itself as "an environmentally correct, socially fair, and economically viable company". While Pöyry is "Engineering Balanced Sustainability," Metso locates sustainability at the company level: "Our knowledge, people and solutions help drive sustainable improvements in performance and profitability in our customers' businesses".

1 http:// biomaterials.storaenso.com/sustainability/veracel (retrieved July 11, 2015). 
The aim of this research project in management and leadership studies is to offer new theoretical instruments for analyzing and understanding complex and asymmetric corporate community relationships. Instead of using the term "CSR," I introduce a more specific concept, corporate community responsibility $(\mathrm{CCR})$, which enables a better delineation of the theoretical discussions. The objective is to study what so-called "external stakeholders" see as significant in CCR. Furthermore, this study is not just about examining how the pulp and paper industry contributes to the wealth of the Indians: it is fundamentally a question of how alternative knowledges could be taken advantage of when discussing local or global development.

This dissertation consists of an introduction and three articles published in peer-reviewed academic journals. The purpose of the introduction is not only to present the societal context of the work in time and space but also to look retrospectively at the research articles and the whole research process. 


\section{RESEARCH SETTING}

\subsection{Theoretical foundations and gaps}

The theoretical focus of the dissertation is on the position of "external stakeholders" - Indigenous Peoples - in the corporate community interaction in the global South. When considering the research field and the relevance and academic contribution of my research, I approach the issue by briefly introducing the pertinent literature and then pointing out several key research gaps. In spite of the mushrooming literature on business ethics and CSR, it is difficult to find a coherent theoretical framework for analyzing and understanding the CCR relationships in the global South. The situation is a reflection of the topic's multidisciplinary nature; examining it only through the lenses of business ethics and CSR literature would leave out some critical aspects. Hence, given my background in regional studies and development studies, it was natural for me to include literature that could enable me to better grasp the problematic related to global-local relations and community development. Thus the theoretical ground of this dissertation is based on multidisciplinary literature, for which I had to collect elements from a wide range of case studies. The extant literature is presented in more detail in the following three research articles, while the last article generates the main theoretical framework, including my own proposal for a CCR model.

Diverting attention from the company-centered "who qualifies as a stakeholder" (Wheeler, Fabig and Boele, 2002) in defining stakeholder groups, and deconstructing business-oriented terms such as "stakeholder mapping," "partnership," "dialogue," and "community engagement" in CSR discourses, my study places the corporate community interaction under critical scrutiny and puts some distance between itself and Eurocentric thinking representing "stakeholder colonialism" (Banerjee, 2008). If we do not take the top-downdetermined stakeholder thinking as the unquestioned truth, a different picture, narrative, and conclusions can be drawn. I would consider this type of a turnaround stakeholder approach quite typical of researchers who have a background in 
development studies. In addition, the community and the concept of community stake, not to mention the Indigenous stake, are rarely considered in business ethics research. While global corporations have become critical development actors affecting local people's livelihoods, cultures, and environment, surprisingly little effort has been made to connect business ethics with development studies and its subdiscipline, development ethics (see Clark, 2002; Sagebien and Whellams, 2010). Mitra (2011) points out that the mainstream CSR debate rarely engages with stakeholder participation's deeper ethics of accountability and grassroots organizing. He offers a culture-centered approach (CCA):

Moving beyond showcasing corporate dominance and unequal power relations, CCA-inspired CSR scholarship must also actively engage with grassroots meaningmaking with subaltern communities, to decipher and strengthen alternative systems of organizing, which re-define "corporate responsibility." The CCA perspective to organization studies differs from conventional frameworks in at least two major ways. First, situated at the intersections of postcolonial theory and subaltern studies, it recognizes collective and individual agency of impacted communities, shifting the locus of study to the affected other rather than the corporation or even its mediating non-governmental organizations. Second, it resists reified understandings of culture as stable and occurring at the macrolevel only, and examines instead how subaltern actors perform or "do" culture across the micro and macro in social interaction, given their structural and material constraints. CCA-guided CSR scholarship, as this article purports to be, then involves both re-construction and de-construction operating dialectically, in its critique of dominant ontologies and epistemologies. My concern here is not so much how companies may strategically frame their CSR policies by selecting what they see as "conducive" parts of local culture (Dirlik 1997), but how subaltern communities may resist organizational hegemony when it threatens their ways of life and thus re-claim CSR in meaningful ways. (Mitra, 2011.)

Thus it is important to search for new, grassroots angles to enrich CCR debates and to focus on the needs and ethical valuations of the society, i.e., the community. In-depth, primary data on the viewpoints of the corporate stakeholders in the global South is seldom collected by business ethics scholars. Concurrently, field research methodologies need to be developed within business ethics in order to take into account and understand Indigenous knowledges vis-à-vis corporations: how do Indigenous Peoples articulate issues related to CCR? Furthermore, CSR research usually seeks input only from corporate managers, nongovernmental organizations (NGOs), and (male) community leaders. It would be useful to interview community members of different backgrounds, such as women, youth, the elderly, and the disabled.

In global companies, CCR issues are often directed to "global communications" or "sustainability" units. For instance, the Finnish companies seem to rely on sustainability aspect when defining CSR (Mbare, Owusu, and Habiyakare, 2008). Ketola (2010) reminds us that the sustainability issue in business mainly implies to the survival in the rapidly changing markets, and promoting the products: "In this rat race environmental, socio-cultural and economic sustainability issues have been pushed aside. Both the already known and potential unsustainable impacts are hidden under the table. Yet there is a huge variety of sustainability lacks in the products and operations of these companies". Ketola has identified the environmental, socio-cultural and economic sustaina- 
bility lacks of three major European forest product companies, including Stora Enso.

The corporate CCR disclosures can be studied from a rhetorical viewpoint, but they are not a very reliable source by which to assess corporate performance, since they tend to present situations in the branch countries in a rosy light. Hence it is necessary to compare corporate words with corporate actions, which requires collecting empirical research data.

Kallio (2007) contends that many scholars avoid touching on the most sensitive and problematic issues related to CSR. The author has identified three "grand taboos" of CSR discourse: amoral business, limitless economic growth, and the political nature of CSR. Kallio states that the critical potential of the field remains underdeveloped as a consequence of the taboos, and in many cases "the CSR discourse merely produces alluring but empty rhetoric about sustainability and responsible business". To study CCR in very asymmetrical power settings and in a different culture is not the lightest or the most popular topic to choose, since the starting point hints that some of the research results may not comfort business circles.

Except for a very few critical studies (e.g., Eweje, 2007; Reed, 2002; Brønn and Vidaver-Cohen, 2009; Jenkins and Obara, 2008), corporate philanthropy is discussed rather unproblematically in the extant literature, as if it intrinsically implies positive performance (e.g. Carrol, 1991; Visser, 2008). This view fails to acknowledge the dynamics and consequences in the corporate community interaction: while a company offers some assets to the stakeholder, the situation is not finalized at that point, but the performance tends to influence the recipients' lives in various ways. Hamann and Kapelus (2004) found not only that philanthropic initiatives in communities had little impact on the root causes of prevailing social problems but that, in fact, many of these root causes were related to the core business practices. Furthermore, even when researchers and firms recognize the role of CSR as a development agent, the focus is usually on what companies do (e.g., philanthropic actions per se, or their outcomes), instead of how they approach development goals and means - in other words, how the companies handle development ethics. There are some academic attempts to offer guidance; for instance, Wheeler et al. (2002) have offered a set of postulates for stakeholder responsiveness.

Much of the global South-related research focuses on resource-extracting industries, but the agribusiness industry and its pulpwood plantations are studied much less. (See e.g. Kröger, 2010; Pakkasvirta, 2008; Lehtinen, 2002.) Although pulpwood production is usually treated within the agribusiness context, there is actually a thin line between the $\mathrm{two}^{2}$, since the entire production process of the eucalyptus plantations has elements that include extraction of natural resources. What is ultimately left is exhausted soil and water resources, diminished biodiversity, and in some cases, the loss of natural forests. In Brazil's

2 This issue came up during the workshop on extractive industries, in the 8th Conference of the Nordic Latin American Research Network (NOLAN), June 11 - 13, 2015, Helsinki, Finland. 
case, a multi-disciplinary study demonstrates the heavy toll that pulpwood plantations take on ecological systems (Ferreira, Gonçalves, Machado, Maracci, Mazzeto, Rocha, Sampaio, and Santos, 2010). Hence my argument is that pulp production represents extractive industries.

Next I discuss in more detail one much-referred-to theoretical formula, namely Carrol's (1991) CSR pyramid addressing organizational stakeholders. The model is based on four CSR component parts: economic, legal, ethical, and philanthropic. According to Carrol, legal responsibilities imply that "it is important to comply with various federal, state, and local regulations." Legal responsibilities "reflect a view of 'codified ethics' in the sense that they embody basic notions of fair operations as established by our lawmakers." Carrol's model is created within the Western ethos, and he does not specify the context of the model-hence it is supposed to be used in different cultural settings. In regard to ethical responsibilities, Carrol suggests that the firm should "perform in a manner with expectations of societal mores and ethical norms". However, I see a few problematic elements in Carrol's pyramid. His regulatory part is limited to the national level; hence it does not acknowledge the international human rights regime, which, especially in the Southern societies, constitutes an important source of principles guiding external stakeholder relations. In addition, since many Southern nations grapple with discriminating practices involving human rights violations by the state itself, which some multinational corporations also overlook or actively participate in, operating in line with these types of societal norms and customs is questionable. Furthermore, Carrol's categorization of the three stakeholder management perspectives offers a relevant list of indicators on the elements describing various management types. However, he does not go deeper into deficiencies and assets in management: what do they imply, and what are their mutual relations? Carrol sees philanthropy as unproblematic, while in practice the corporate community interaction situations are very complex. In addition to the above deficiencies, I consider his model too corporate-centered. I regard Carrol's pyramid model as of very limited value when attempting to interpret and understand the Southern CCR situations in depth. As a general conclusion, the theoretical modeling of CCR lacks more accurate and diversified criteria in the global South contexts.

Moreover, the multidisciplinary nexus between business ethics and public law is a little-studied area. In the case of the Indigenous Peoples, the notion of a rights-based approach raises the struggles and conflicts to a new level by pointing out the existence of the strong regulatory context protecting their rights, which cannot be overlooked.

Mitra (2011) notes that although contextualized, emerging economyspecific concerns have been articulated in a few studies, they are "mainly from a policy or strategic perspective, instead of examining how local/global sociopolitico-economic flows constitute and evolve CSR meanings". He also notes (referring to Iyer, 2008) that "few studies of business ethics delve into the historical development of State power, institutions, such as the media and judiciary, economic sectors, corporate groups, and whole industries". Mitra argues that in 
his country case, India, a strong neoliberal profit-centered agenda remains at the core, in which the "mainstream discourse frames a facade of nation-building, which systematically and strategically de-legitimizes subaltern voices opposed to this neoliberal agenda". This situation greatly resembles that of Brazil, which is discussed in Chapter 2.3.

\subsection{Research objectives}

The main research question of this study is: How has the Finnish forest industry cluster fulfilled its corporate community responsibility on Brazil's Atlantic coast with regard to Indigenous communities? The purpose of this dissertation is to increase knowledge of a wider CCR phenomenon taking place in Brazil, Latin America, and elsewhere in the global South, whenever there are territory-based, socio-environmental conflicts. The research approach is based on knowledge derived from the grassroots, rather than taking the usual top-down perspective.

The main research question can be divided into several sub-questions according to the actor groups studied and the assessment of the relationship:

Indigenous communities:

1. How do Indigenous communities perceive the influence of pulp production on their livelihoods, environment, culture, identity, and mutual community relations?

2. How do communities articulate and defend their rights and interests?

3. Do the communities expect certain CCR actions from the firms, and if so, what are these?

4. How do the communities perceive the influence of CCR initiatives on their lives? Have they benefited from social programs and other forms of corporate philanthropy?

5. How do they define what constitutes a "responsible" firm?

6. What does the land struggle - a luta pela terra-mean to the Indians?

\section{Corporations:}

1. In what ways are the Finnish companies involved in pulp production in the region?

2. How do the firms seek societal acceptability and legitimacy, both in Brazil and Finland? What kind of agendas and tactics have they implemented, locally and nationally?

3. How do the Finnish firms perceive Indigenous Peoples as stakeholders, and how have the firms reacted to their territorial claims and CCR expectations? How are the Indigenous Peoples presented in corporate communications, such as on the Internet and other media?

4. How do the firms define their CCR principles in theory, and what has the practical relevance of such principles been (comparing corporate actions with corporate words?): i) What kind of CCR initiatives have 
the firms introduced, and how have they carried out these initiatives?

ii) What kind of corporate disclosures do they present?

5. How ethically have the firms' Brazilian business partners and subcontractors acted towards Indigenous Peoples? How have the Finnish firms responded to various incidents related to the land disputes?

6. How do the firms set boundaries for their CCR?

At a more general level, the aim of this research is to consider the following CCR issues:

1. What kind of developmental role do the Finnish companies play in Brazilian society? What kind of interfaces take place between intended development interventions and actual development processes?

2. Are CCR initiatives always "doing good" in local communities?

3. Why and how has the legitimacy of the Finnish companies become questionable?

4. When comparing empirical material to basic corporate social responsibility concepts in business ethics literature (such as e.g. "stakeholder," "partnership," and "dialogue"), how relevant are they in interpreting the phenomenon in the global South? Furthermore, what kind of alternative indicators, concepts, and approaches are needed in order to analyze corporate community relations?

5. How can "socio-environmental conflict" be defined based on these findings?

6. How could the asymmetry between two actor groups be balanced (modeling the CCR principles)?

\subsection{The political economy context}

To better understand the historical roots of pulp production and corporate community case studies here, it is necessary to ground them in a political economy framework. Hence a brief overview of the selected critical turning points and key actors in Brazil's history is offered - these elements and names will also often appear in my research articles. First, the main changes in government regimes and trends in socioeconomic development are presented. Second, as a reflection on the previous developments, an overview of the situation of the Indigenous Peoples in Brazil is presented, also with the context of recent socioenvironmental conflicts in South America.

\subsubsection{A route from colonialism to extractive capitalism}

In Brazil's history, certain societal forces - politics, economics, land ownership, natural resources extraction, MNCs, and the position of Indigenous Peoples have been firmly interrelated. At this point in the research process, when the 
empirical material has been collected from the field, it is possible to trace certain characteristics and long-term trends, i.e., dominating factors in the Brazilian political economy affecting recent incidents in corporate community relations on Brazil's Atlantic coast. The following governmental eras can be addressed chronologically: i) Portuguese colonization from 1500 to 1815; ii) independence in 1822 and the monarchical regime, the Brazilian Empire; iii) president and dictator Getúlio Vargas (Liberal Alliance) 1930-1945 and 1951-1954; iv) President Juscelino Kubitschek (Social Democratic Party) 1956-1961; v) The civilianmilitary dictatorship (1964-1985); vi) President Fernando Henrique Cardoso (Brazilian Social Democracy Party) 1994-1998; vii) President Luiz Inácio "Lula" da Silva (Workers' Party) 2002-2006; and his successor, representing the same party and the 36th president of Brazil, viii) President Dilma Roussef (Workers' Party) 2010-2014 and 2014-present. Furthermore, I wish to consider the following seven interlinked features, which constitute the foundation for the contemporary pulp-based and other socio-environmental conflicts in Brazil:

1) Colonial economy. Brazil became a colony of Portugal, the first global empire, in the 16th century:

Thus was established the nexus of the Brazilian colonial economy: land-extensive single-crop agriculture based on slave labor, concentrated primarily in the Northeast. This plantation system generated the hierarchical society of the colonial era. It was, in turn, part of the South Atlantic economy, which the Portuguese controlled on both sides of the ocean - one side the source of slaves (West Africa), the other side the location of their work (Brazil). By the seventeenth century, the Brazilian Northeast was one of the richest regions in the Americas, surpassing New England or Virginia. At the same time, however, the intensive cultivation of sugar was to inflict deep ecological damage on the Brazilian Northeast. (Skidmore, 1999, 20.)

Aside from brazilwood and sugar cultivation, the rural economy of the colonists in the northeastern interior was based on raising cattle (ibid., 1999, 29.) In newly independent Brazil, the export economy was dominated by agriculture and mining. As the latter declined, sugar, tobacco, cotton, and coffee were the prime exports. By 1830, coffee appeared as a new product, one that fueled Brazil's export economy for the next 140 years. (See Laakkonen, 1996; Skidmore, 1999, 39, 40.)3 (Map 1.)

3 The history of plantation crop cycles in Brazil (and much of Latin America) is roughly the following: brazilwood 1500-1550; sugar 1550-1700; gold and diamond rush 17001775; rubber and coffee 1850-1930. Cattle ranching became dominant in the 1930s, and more recently, eucalyptus has replaced many of the previous crops. (Marchak, 1995, 269.) 


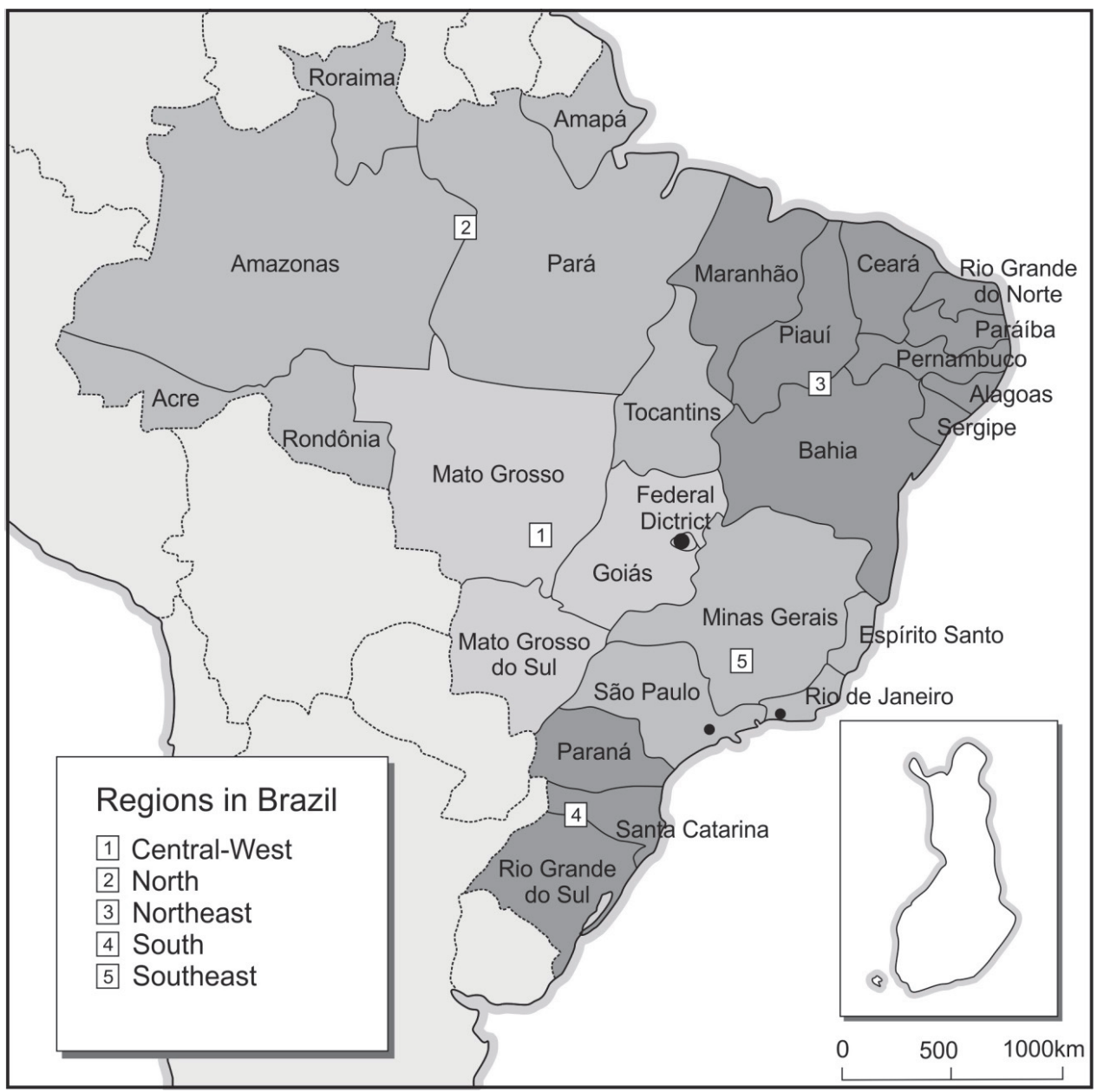

MAP 1 Regions of Brazil.

2) Concentration of land ownership. Land has always constituted a principal source of wealth in Brazil. During the colonial era, land ownership was based on a succession of royal land grants made by the monarch personally. This system, in turn, led to a pattern of ad hoc land claims that rested on physical possession rather than legal recognition. The growth of commercial export agriculture, particularly coffee, played a crucial role in the development of the land ownership system. In 1850, a new land law was intended to favor the holders with large plantations, especially in export agriculture. This can be considered the beginning of a path that has had major implications for socioeconomic inequality in contemporary Brazil. (Skidmore, 1999, 50-52.) The country's independence strengthened the lopsided land tenure structure, and eventually a small minority of the landholding elite controlled the nation-a phenomenon that was strongest in the northeast, Rio de Janeiro, Minas Gerais, and São Paulo. President Vargas, representing himself as a fazendeiro (Brazilian planter or cat- 
tleman) of Rio Grande do Sul, promoted domestic policy that did not threaten the existing land tenure system. (Frank, 1969, 8; Skidmore, 1999, 37-39, 131, 235; see also Bresser-Pereira, 2012).

Contemporary Brazil has one of the most unequal landholding structures in the world. Just 1.5 percent of rural landowners occupy 52.6 percent of all agricultural land in the country. (Clements and Fernandes 2012, citing DATALUTA 2011). Having roots in the colonial past, the agrarian question has long been contentious in Brazil. The present forms of foreign land occupation by transnational agribusiness have changed the conditions for the agrarian struggle. (Clements and Fernandes, 2012.) The foreign purchase of land has led to significant increases in land prices nationwide (ibid., citing Chiara 2011). Land acquisition for eucalyptus production has also increased land prices in the coastal areas, which in turn has complicated agrarian reform, since the government can no longer afford to purchase the land in these areas (Andersson and Barthholdson, 2004, 28-29).

3) National developmentalism. At the dawn of the 1950s, Brazil's economy was largely defined by the production and export of agricultural commodities. Due to a national policy of incentives for industrialization, the pulp and paper industry became prominent in the Brazilian economy between the 1940s and the 1960s (Miola, 2010). This was also a crucial period in Brazil's transition from an agrarian and export-oriented economy into an urbanized and industrial society (Ioris and Ioris, 2013):

Combining repression, persuasion and paternalism, the national state took a significantly political and economic responsibility in the social, material and symbolic modernization during the Vargas and Kubitschek administrations. However, internal disputes, foreign demands and a long legacy of socio-spatial inequalities prevented the achievement of more socially inclusive goals, leading a legacy of unanswered questions that still have currency today. (Ioris and Ioris, 2013.)

During Vargas's and Kubitschek's eras, Brazil was a dynamic, industrializing nationalist economy. It was based on strong state interventionist policies that involved subsidizing and protecting the growth of national public and private enterprises. The strong developmentalist strategy from the 1930s through the mid-1980s led to impressive growth. (Petras, 2013; see also Bresser-Pereira, 2012.) During Vargas's rule important state enterprises were created, such as the Brazilian Development Bank (BNDES), as well as Petrobras, a giant Brazilian petroleum monopoly (later privatized by Cardoso). Kubitschek's agenda was based on large-scale development schemes and its two key initiatives. First, to develop Brazil's interior, he started building the city of Brasília in 1957 so the capital could be moved there from Rio de Janeiro. To many Brazilians, the completion of this massive but extremely rapid project was an affirmation that Brazil was "a country of the future, somehow on a higher level than its South American neighbors". (Skidmore, 2010.) Second, the "Plano de Metas" (Plan of Goals) focused on the development of five key areas: energy, food, industry, education, and transport, which were aimed at modernizing and diversifying the Brazilian economy. (Ibid., 2010.) It has been argued that the ambitious eco- 
nomic development program led to a continuing balance-of-payments crisis and initially to a stabilization program (Skidmore 1999, 146).

4) Dependent developmentalism. The era can be described as an alliance between an authoritarian state and "big capital" (cf. Cho, 2000). The civilianmilitary dictatorship encouraged and attracted foreign investment and MNCs by lowering tariffs while strengthening industrialization in order to accelerate economic growth. Evans $(1979,32,368)$ has described Brazil's economic policy during the military regime as containing various sources of capital working at cross purposes: a "triple alliance" between state-owned enterprises, multinational corporations, and local private firms. He demonstrates how the industrialization-led economic growth benefited the narrow Brazilian elite and excluded the wider population. Both national and foreign investors in the pulp and paper industry benefited from the BNDES credit system, which thus played an important role in the development of the sector. (See also Kröger and Nylund, 2012; Oliveira, 2008).

Eucalyptus proved to be the main fast-growing wood in the country. Plantations and cellulose pulp mills were situated primarily in the neighboring northeastern and southeastern states of Bahia, Espírito Santo, and Minas Gerais. It is notable that, ever since the military government, different political regimes have continued to promote large-scale forest enterprises and plantations. The successful forest policies have entailed generous fiscal subsidies, large loans, and the removal of legal obstacles. (FASE, 2006, 1; Andersson \& Bartholdson, 2004,87 .) The contemporary plantation industry is not quite similar to its predecessors, since it is dominated by foreign companies (Marchak, 1995, 269).

5) Unequal welfare effects. Through various government regimes, the pyramid-structure of Brazil's society strengthened, and it is in a mutually reinforcing relationship with the unequal justice system. On the lowest rung of the ladder are the Indigenous Peoples. In addition, development has been urbanbiased, and industrial workers have earned more than workers in the agrarian or service sectors. Rural areas have suffered from urban migration toward the industrialized South. (See Skidmore, 1999, 39, 116, 143-152, 174-178). According to Skidmore (1999, 237-238), "The elite repeatedly showed indifference to the need to invest in human capital, except for their own children... Brazilians deserve a leadership that can come to understand why a viable capitalism requires genuine democracy. Only when the participation of all Brazilians becomes a reality can Brazil achieve the just society for which its citizens have long striven."

6) Struggles over resources and the legacy of violence. Since Brazil's democratization in 1985, race relations have continued to focus on Afro-Brazilians. The position of the Asian-Brazilians and Indians has gained remarkably less attention. There have been minor changes in race relations, discrimination, and the culture of violence since the abolition of slavery in 1888. Wealth-holders, that is, landowners and many industrialists, have always had close links to the police and the military, who have guaranteed their assets by intervening in conflict situations, such as land struggles. Moreover, although foreign companies de- 
nounced the political repression of the authoritarian regime, they did not stop supporting Brazil's economic policy. (Skidmore, 1999, 154, 174-178, 208.)

Instead of land redistribution and agrarian reform, the economy-highly dependent on coffee cultivation-underwent a large-scale diversification; the country became a major exporter of orange juice concentrate and soybeans in the 1980s. In the agricultural sector, the federal government's rural credit policy and the granting of export subsidies benefited primarily the large commercial farms and were accompanied by the opening of new lands. Hence the agricultural expansion occurred in the cerrado, a vast western territory previously lacking transportation facilities. The expansion also reached the western Amazon Basin and western Bahia. The inadequate financial state budgets for the environmental ministry, combined with ambiguous leadership in the capital, offered the (many illegal) loggers and the slash-and-burn settlers almost free rein. The expansion into new regions involved violence towards the Indians, relentless destruction of the rainforest (since the 1960s), and a growth in income differentials among regions and socioeconomic classes. (Skidmore 1999, 179-180, 231.)

7) Extractive capitalism and land grabbing. Brazil, like Latin America as a whole, has experienced two decades of neoliberalism. It has been mostly funded by transnational corporations running aggressive extractivism of the continent's rich natural resources. (Bury, 2007; Sullivan, 2014.) Lula has been criticized for intensifying the existing shift from his neoliberal predecessors towards extractive capitalism, or agro-mining capitalism: the country became dependent on commodity exports, aided by the massive entry by MNCs and financial flows from overseas banks. Overall, Lula's policies have led to an agribusinesscentered politics in Brazil (See Boito, 2007, 66-67; Borras, Franco, Gomez, Kay, and Spoor, 2012; Gomes, 2000, 231-232; Petras, 2013.)

According to Clements and Fernandes (2012), Brazil's modernization and state-led programs have enabled various forms of land grabbing and creating business spaces for foreign investments. Moreover, agribusiness has come under substantial foreign control, and investments by multinationals in the ethanol industry have grown substantially. This hegemonic development path has had enormous social and environmental impacts. (Ibid.) Land grabbing and massive ecological impacts have likewise resulted in the pulp and paper industry. On the other hand, Brazil has become one of the world's leading economies and hence a powerful global actor in agribusiness. While Brazil is subject to land grabs by foreign capital, the country, in turn, has become a promoter of land grabs in Africa, especially in Mozambique. (Ibid.; see also Marchak, 1995, 269-301.)

The next two chapters briefly introduce the historical and current human rights situation of Indigenous Peoples vis-à-vis Brazil's political economy. Various development schemes of the government and the expansion of foreign business investments, not only in Brazil but also in Latin America, have pushed the ex- 
tractive frontier deeper into Indigenous Territories, causing the phenomenon of Indigenous land grabbing.

\subsubsection{The natives discovered}

On April 21, 1500, a Portuguese expedition headed by Pedro Álvares Cabral approached the paradisal New World of Brazil's Atlantic coast. A mountain called Monte Pascoal rose from a lush rainforest. The next day Cabral landed in Porto Seguro and claimed "Terra da Vera Cruz" - now Brazil - for the crown of Portugal. (See Prezia, 2002; Filgueiras and Peixoto, 2002; Bueno, 2006, 29-32; Gomes, 2000, 28-56) The territory was named after the red-colored brazilwood trees found there.

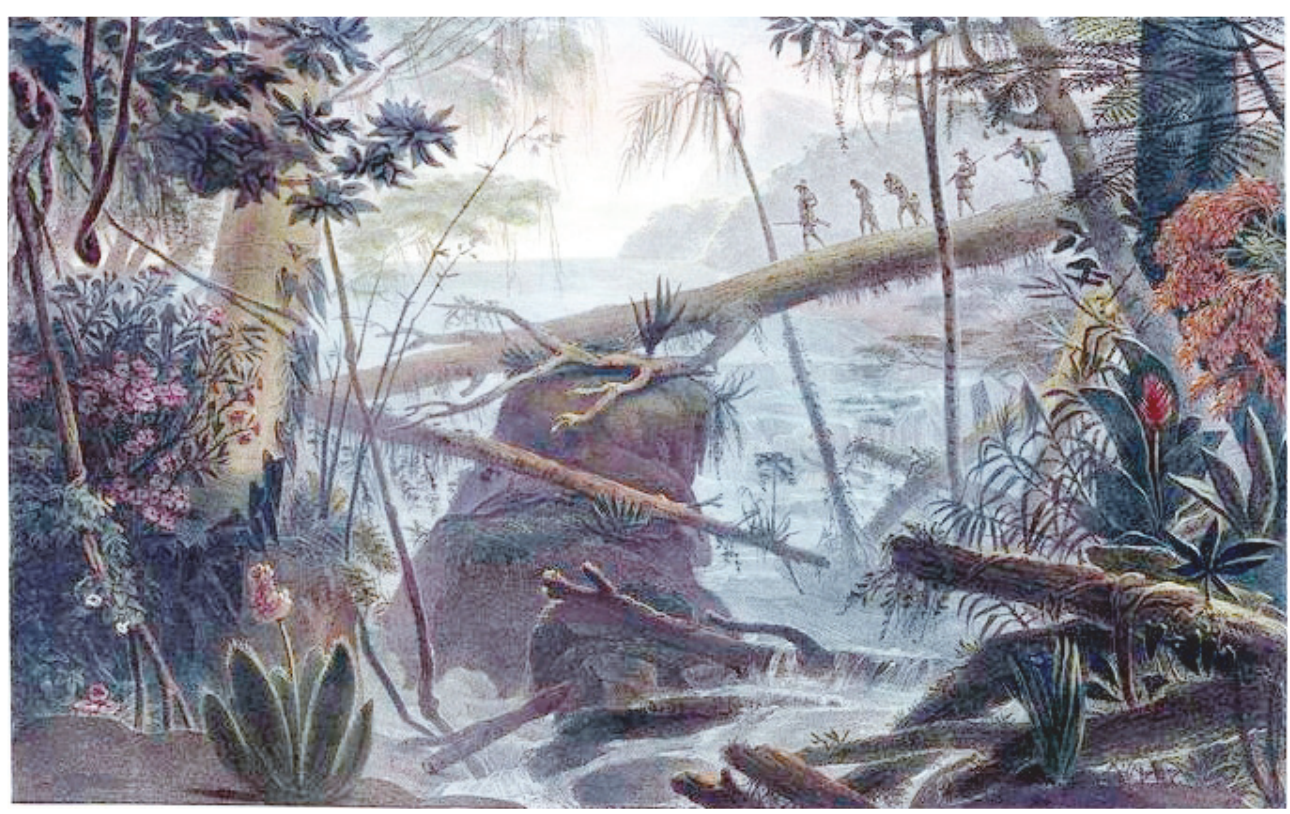

IMAGE 1 Jungle in the Paraíba do Sul river margins by Jean-Babtiste Debret, 1834-1839 (New York Public Library, Digital Gallery).

The stated intent of this expedition was the same as the earlier one: to head for the southern tip of Africa, sail around the Cape of Good Hope, and head north toward India through the Indian Ocean. Almost as soon as the fleet had set out to sea, however, disaster appeared to strike. The lead ship, commanded by Cabral, swung off course into the Atlantic, sailing due west. Cabral and his crew eventually reached the coast of what is now the Brazilian state of Bahia, arriving on April 23, 1500. They had stumbled on what turned out to be a vast continent. Or was it more than stumbling? There has been considerable speculation over the years that the Portuguese navigators knew exactly what they were doing, that they had in fact planned this "accident" to outflank the Spanish, who had already claimed so much of the new world, and that they were really following the route of previous secret voyages to Brazil. Historians have failed to uncover any evidence in the Portuguese archives or elsewhere to support this version of events. If there were, indeed, previous secret voyages to the new continent, they are still secret. Nor, of course, was the continent new to the sev- 
eral million indigenous Indian people who already lived there. There is no record of what the Indian residents thought as they were "discovered" by a band of strange sailors with odd clothes and a bad smell, but their reaction can well be imagined. The reaction of Cabral and his men is known: They were fascinated by what they saw. Their thoughts were captured in an official account written for King Manuel by Pero Vaz de Caminha, the fleet's scribe. His "Carta" (letter) demonstrated a typical lateRenaissance perception of the new land, naturally emphasizing what was exotic to European eyes. Vaz de Caminha depicted a realm where the resources - human and environmental - were there for the taking... The image of endless fertility was to capture the imagination of the Portuguese and later the Brazilians, a romanticization that has led to a variety of overoptimistic estimates of Brazil's potential. (Skidmore, 1999, 5-6.).

At the time of Brazil's "discovery" by the Portuguese, there were at least 1,400 native groups widely distributed along the coast and inland. This was shown in the detailed and ethnic-historical map by German-Brazilian ethnologist and anthropologist Curt Nimuendajú. (Map 2.). It also proves that the forefathers of the three Indigenous groups studied in my dissertation - the Tupinikim, the Guaraní, and the Pataxó-actually settled the region and hence are the traditional landholders. This fact has been contested in present times by pulp corporations and fazendeiros. Moreover, their native ancestors had lived on this land as many as 30,000 years ago.

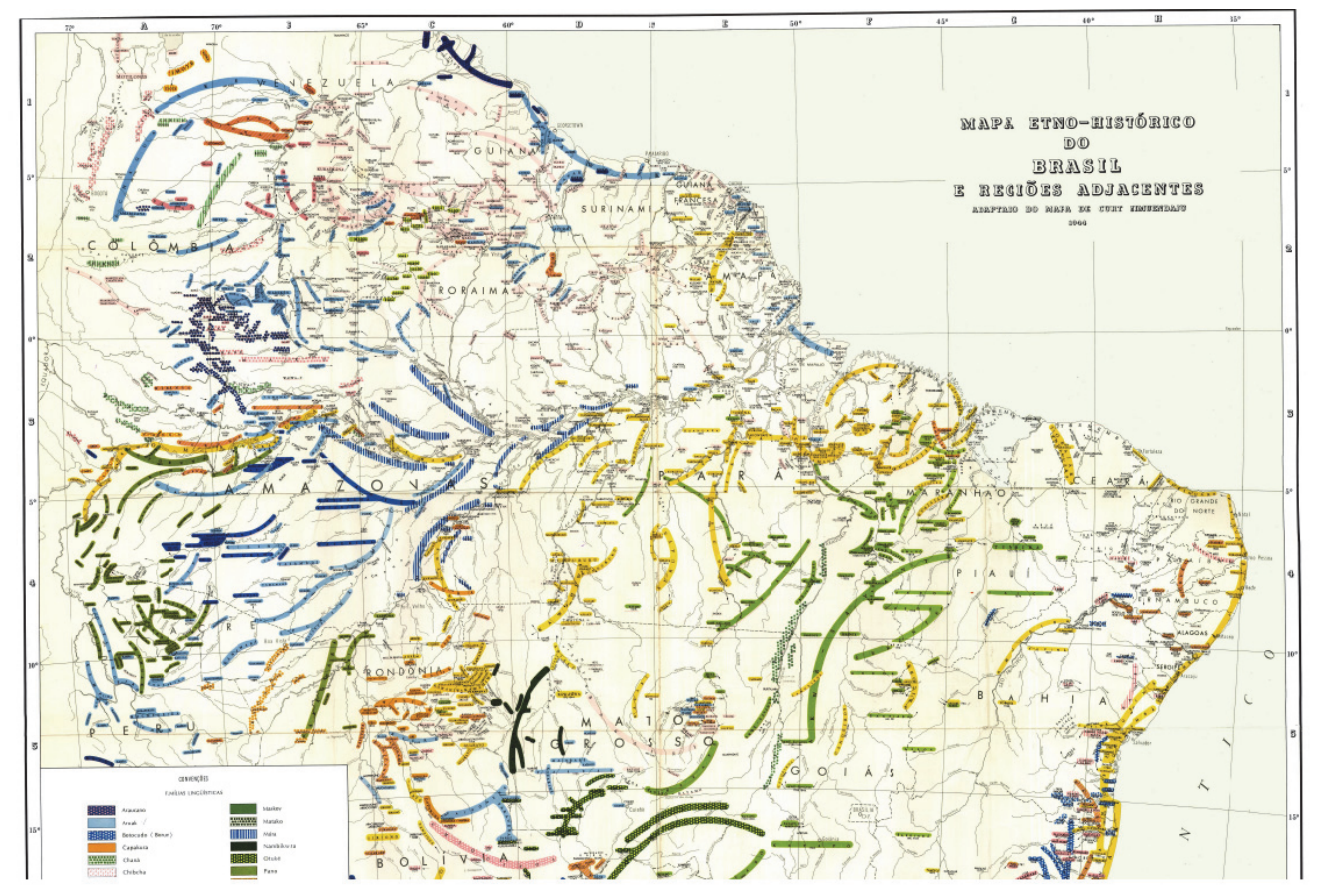

MAP 2 A part of the large ethnic-historic map by Curt Nimuendajú, 1944. The map has thousands of names, symbols, and colors representing 1,400 groups of Indians (IBGE, Brazilian Institute of Geography and Statistics. Ed. Facsimile. Rio de Janeiro: IBGE; [Brasilia, DF]: Ministry of Education. 2002. 94 p. il, color map. 
These native groups were divided into more than a hundred separate language groups. The total native population has been estimated at anywhere from 500,000 to 2 million, with one estimate as high as 8 million. Monteiro (1994) is cautious on these numbers, since the political interests and methods of authors may affect the result. Nevertheless, the Indian population number shrank drastically, largely due to epidemic diseases brought by the Europeans. Harsh treatment by the Portuguese further obliterated Indigenous populations; those who survived the Portuguese impact retreated to the temperate interior. The Portuguese, who settled mainly in small colonies along the coast, soon realized that the Indians could not provide sufficient labor for brazilwood harvesting and the cultivation of sugar cane. Hence they turned to West Africa, where Portuguese slave traders established stations until 1850. By the end of the 18th century, the northeastern "sugar society" had nearly erased Indians from the coastal region. (Skidmore, 1999, 10-19.) Thus the Indigenous Peoples' situation changed dramatically at the start of the 21st century, as the following chapter discusses.

\subsubsection{The contemporary human rights situation of the Indigenous Peoples}

The remnants of a vast number of Indian tribes that existed in 1500 are today confined to so-called Indian reservations or more or less assimilated into the dominant society. Indigenous Peoples live in communal territories in varying degrees of isolation ${ }^{4}$. These territories are geographically dispersed and possess diverse types of protection status. In Brazil there are 243 Indigenous ethnic groups or tribes 5,49 of which have part of their population living abroad. According to the latest IBGE (Brazilian Institute of Geography and Statistics) population census from 2010, 817,963 individuals in Brazil identify as Indigenous 0.42 percent of the country's total population of over 200 million. Despite the fact that some groups have decreased in number, or may even disappear entirely (seven groups have populations of between five and 40 individuals), the overall Indigenous population has been growing in the last 28 years. They speak 150 different languages and are located in thousands of Indigenous villages or aldeias within 700 Indigenous Territories (ITs). Brazil's total land area is $8,511,965 \mathrm{~km}^{2}$, of which Indigenous Territories constitute 1,135,993 $\mathrm{km}^{2}$. Hence approximately 13 percent of the country is reserved for the Indians. However, nearly all these Indigenous lands (98.5 percent) are situated in the Amazon. Moreover, although roughly half of all Brazilian Indians live outside the Amazon, these groups only occupy 1.5 percent of the total land reserved for Indians in the country. (IBGE, 2010; IBGE, 20156.)

\footnotetext{
http://www.funai.gov.br/ (retrieved June 6, 2015).

Although the term has some negative connotations (see, e.g., Virtanen, 2007, 3), the Indigenous Peoples I interviewed often used the word "tribe".

http://indigenas.ibge.gov.br/mapas-indigenas-2;

http://indigenas.ibge.gov.br/graficos-e-tabelas-2; Instituto Socioambiental

(http:/ / www.socioambiental.org/pt-br); and Survival International

(http://www.survivalinternational.org/) (retrieved June 2015).
} 
Out of the total number of Brazilian Indigenous Peoples, 502,783 live in rural areas and 315,180 in cities (IBGE, 2015). The IBGE 2015 statistical map shows that the concentration of Indigenous Peoples in urban areas between 1991 and 2010 has been explosive, especially in metropolises but also in secondary cities. Regionally the increase has been concentrated in the coastal region?. The reason for this, I believe, is not merely because the major cities (which are particularly attractive to youth) are located there; the phenomenon could also be influenced by growing pressure on coastal rural Indigenous communities. Urbanization, especially of Indigenous youth, is getting more attention among researchers (see, e.g., Virtanen, 2007).

Nowadays the largest tribe, albeit one with little land left, is the Guaraní $(51,000)$. The tribe's lands have been forcibly transformed into a vast production network of soya fields, sugar cane plantations, and cattle. The Guaraní are forced to settle in overcrowded reserves, while the rest try to manage in urban areas and roadside tents. ${ }^{8}$ Furthermore, since the Guaraní are (yet not nomadic) people, they pose a problem for the nature park authorities and IBAMA (the Brazilian Institute of Environment and Renewable Resources), as I observed during my field research. The director of the Cardoso Island State Park alleged that the Guaraní hunt the endangered jaguar for food. This situation was also typical of more sedentary Indigenous groups. One reason for the conflicts between IBAMA and the Indians was due to IBAMA's reluctance to grant permissions to use natural resources in conservation areas. Nevertheless, the Indians have a constitutional right ("original right") to extract various natural resources, including rare animal and plant species, from the nature parks as well. As one anonymous IBAMA (personal communication, 2004) representative stated:

If you have an Indigenous land and a Protected Area, sorry for the latter.

The Yanomami $(19,000)$ hold the largest territory in the northern Amazon, while the Tikuna $(40,000)$ are the largest Amazonian tribe in Brazil. The existential uncertainty the Indigenous Peoples face is alarming; many Amazonian tribes have fewer than 1,000 members. For example, the Awá consists of 450 people, while the Akuntsu tribe has only five people. ${ }^{9}$ According to the IBGE (2010), there were 433,363 people living in the Amazon. Indigenous Peoples are located in 24 of the country's 27 states, except Piauí, Rio Grande do Norte, and the Federal District ${ }^{10}$.

Concerning the national-level regulatory context, the 1988 Brazilian Constitution recognizes the inalienable right and hence the ownership of Indigenous Peoples to land areas they have traditionally occupied: the Indians are to be treated as the original and rightful owners of Brazilian lands. The Constitu-

\footnotetext{
7 http://indigenas.ibge.gov.br/images/indigenas/mapas/pop_indigena_URB_91.pdf (retrieved June 2015)

8 Instituto Socioambiental (http://www.socioambiental.org/pt-br) (retrieved May 2015).

9 Survival International (http:/ / www.survivalinternational.org/) (retrieved June 2015).

10 Conselho Indigenista Missionário (http:/ / cimi.org.br/site/pt-br/)(retrieved June 2015).
} 
tion established the juridical concept of "Indigenous Lands" that was also defined in specific legislation. However, some conflicting issues also exist in the regulatory framework, especially regarding relations between the Indians and society. Older legislation, the Indian Statute of 1973 (which is still in force), stipulated that the Indigenous population was to be fully integrated into society by the "tutelage" of an Indigenous organization - the National Indian Foudation (FUNAI), the Brazilian government body responsible for Indigenous land demarcations) ${ }^{11}$. Breaking the old paradigm that demanded the assimilation of Indians into the surrounding society and its culture, the Constitution declared the existence of different forms of society and thus affirmed a multiethnic identity in Brazil ${ }^{12}$. (See Table 1.)

TABLE 1 The Chapter on Indigenous Rights in the Brazilian Constitution ${ }^{13}$

\section{CHAPTER VIII - INDIANS}

Article 231. Indians shall have their social organization, customs, languages, creeds and traditions recognized, as well as their original rights to the lands they traditionally occupy, it being incumbent upon the Union to demarcate them, protect and ensure respect for all of their property.

Paragraph 1 - Lands traditionally occupied by Indians are those on which they live on a permanent basis, those used for their productive activities, those indispensable to the preservation of the environmental resources necessary for their well-being and for their physical and cultural reproduction, according to their uses, customs and traditions. Paragraph 2 - The lands traditionally occupied by Indians are intended for their permanent possession and they shall have the exclusive usufruct of the riches of the soil, the rivers and the lakes existing therein.

Paragraph 3 - Hydric resources, including energetic potentials, may only be exploited, and mineral riches in Indian land may only be prospected and mined with the authorization of the National Congress, after hearing the communities involved, and the participation in the results of such mining shall be ensured to them, as set forth by law. Paragraph 4 - The lands referred to in this article are inalienable and indisposable and the rights thereto are not subject to limitation.

Paragraph 5 - The removal of Indian groups from their lands is forbidden, except ad referendum of the National Congress, in case of a catastrophe or an epidemic which represents a risk to their population, or in the interest of the sovereignty of the country, after decision by the National Congress, it being guaranteed that, under any circumstances, the return shall be immediate as soon as the risk ceases.

Paragraph 6 - Acts with a view to occupation, domain and possession of the lands referred to in this article or to the exploitation of the natural riches of the soil, rivers and lakes existing therein, are null and void, producing no legal effects, except in case of relevant public interest of the Union, as provided by a supplementary law and such

11 Instituto Socioambiental (http:// pib.socioambiental.org/en/c/direitos/estatuto-doIndio/introducao) (retrieved June 2015).

12 http:// uanativenet.com/topicitem/Topics\%20In\%20Brief/234 (retrieved June 2015).

13 Quotation from: http://www.v-brazil.com/government/laws/titleVIII.html (retrieved June 2015). 
nullity and voidness shall not create a right to indemnity or to sue the Union, except in what concerns improvements derived from occupation in good faith, in the manner prescribed by law.

Paragraph 7 - The provisions of article 174, paragraphs 3 and 4, shall not apply to Indian lands.

Article 232. The Indians, their communities and organizations have standing under the law to sue to defend their rights and interests, the Public Prosecution intervening in all the procedural acts.

Brazil's 1988 constitution mandates the demarcation of Indian lands within five years. There are six stages in the official demarcation of Indigenous Territories $(\mathrm{ITs})^{14}$. First is identification: FUNAI appoints an established anthropologist whose study substantiates the research of a specialized multidisciplinary working group. It examines an area's ethno-historical, sociological, legal, cartographic, and environmental features and conducts a land survey. Second is approval: the final report from the identification studies must be approved by FUNAI. Third is disputes: a report summary should be published in the state newspaper so that anyone interested, including states and municipalities, can dispute the report within 90 days. FUNAI has 60 days to assess the complaints. Fourth is declaration: within 30 days, the minister of justice should issue a directive declaring the size and limits of the area, as well as to determine when its physical demarcation should start. Fifth is demarcation: Once the area limits are declared, FUNAI is expected to advance the area's physical demarcation. Alternately, if the declaration does not take place within the given time frame, judicial proceedings will follow within another 90 days; otherwise, the Ministry rejects the identification. Sixth, the approval: demarcation procedure must be submitted to the president of the republic, who approves and signs the demarcation, which is issued by decree. Seventh is registration: Within a maximum of 30 days after approval, the demarcated Indigenous Territory must be registered in the notary of the correspondent judicial district and at the Office of Patrimony of the Union. (Ibid.)

Hence the regulatory framework for registering ITs is theoretically clear. Nevertheless, numerous Indigenous groups continue to experience a long wait for IT finalization. The recent (July 2015) statistics on the legal status of Indigenous Lands in Brazil shows that there are a total of 700 ITs, of which 422 are officially registered, while the rest are still in process. ${ }^{15}$ Nine years ago the corresponding numbers were 851 ITs, of which 325 were registered ${ }^{16}$. The inefficiency of the Brazilian legal system has put the Indigenous communities in a vulnerable position. Corporations and other actors tend to step in and take ad-

14 See Conselho Indigenista Missionário (http:/ / cimi.org.br/site/pt-br/); Instituto Socioambiental (http://www.socioambiental.org/pt-br) (retrieved June 2015).

15 Instituto Socioambiental (http://www.socioambiental.org/pt-br) (retrieved June 2015).

16 Conselho Indigenista Missionário (http://cimi.org.br/site/pt-br/)(retrieved June 2015). 
vantage of the exceedingly slow legal procedures and the under-resourced and internally problematic (not to mention occasionally corrupt) FUNAI. That is not to say that a registered IT guarantees full protection for these communities, as the final section of this chapter demonstrates. The state's negligence and (subsequent) long-term conflicts with national and multinational corporations and other actors - small and large landowners, the hotel/tourist industry, and rural peasants/landless people-have led to protracted legal disputes for many decades, as my dissertation also demonstrates. (See, e.g., Bier, 2005.)

Bier (2005) points out that the protection of Indigenous rights is not exclusively an issue of the Brazilian government. A number of important legal frameworks exist, which the country has signed, such as International Labor Organization (ILO) Convention No. 169 (i.e., the Indigenous and Tribal Peoples Convention, 1989); the 1948 United Nations Declaration of Human Rights; the 1994 United Nations Declaration on the Rights of Indigenous Peoples (UNDRIP); the 1996 International Covenant on Civil and Political Rights; the 1966 International Covenant on Economic, Social, and Cultural Rights; and the 1972 Stockholm Declaration on the Human Environment. Of all these conventions, the most important international instruments are UNDRIP and ILO Convention No. 169, since these two are compatible and mutually reinforcing, and they define Indigenous Peoples' rights to lands, territories, and resources under international law. Furthermore, as Feiring (2013) clarifies, Indigenous Peoples' rights are not "special" rights, and UNDRIP and Convention No. 169 do not extend or invent any "new rights". On the contrary, the two instruments are articulations of universal human rights as they apply to Indigenous Peoples. (Feiring, 2013, 16; see also United Nations, 2013.) (See Table 2).

TABLE 2 Fundamental principles of Indigenous Peoples' rights according to UNDRIP and ILO Convention No. 169 (quoted from Feiring, 2013, 17-18, emphasis added).

The concept of territories

Indigenous peoples do not have rights only to the land they directly cultivate or inhabit, but to the broader territory, encompassing the total environments of the areas which they occupy or otherwise use, inclusive of natural resources, rivers, lakes, and coasts. Their rights to land and natural resources require special attention, as these are fundamental to securing the broader set of rights related to self-management and the right to determine their own priorities for development.

Collective rights

Indigenous peoples' land rights comprise both individual and collective aspects. Whereas most indigenous peoples have customary ways of recognizing land and resource rights of individual members or households, the collective aspects of their rights to lands, territories, and resources are intrinsically linked to their collective rights to self-determination, nondiscrimination, cultural integrity, and development as distinct peoples. 
Traditional occupation, ownership, or use

Indigenous peoples have rights to the lands, territories, and resources that they have traditionally occupied, owned, or used, meaning that it is "the traditional occupation and use which is the basis for establishing indigenous peoples' land rights, and not the eventual official recognition or registration of that ownership" (ILO, 2013, 21).

Natural resources pertaining to their lands

Indigenous peoples have rights to the natural resources of their territories, including the right to own, use, develop, and control these resources. As a basic principle, "these resources comprise both renewable and non-renewable resources such as timber, fish, water, sand and minerals" (ILO, 2009: 107). In cases where states retain ownership over mineral and sub-surface resources, Convention No. 169 (article 15.2) stipulates that indigenous peoples have rights regarding consultation, consent, and participation in the benefits of resource exploitation, as well as compensation for damages resulting from such exploitation.

Lands not exclusively occupied by indigenous peoples

Many indigenous peoples have traditionally had access to and used lands, territories, or resources that are also used by other communities or population groups. The ILO elaborates: "This is especially the case with grazing lands, hunting, fishing and gathering areas and forests, which may be used by nomadic pastoralists, hunters or shifting cultivators on a rotational or seasonal basis. In other cases, certain communities may have rights to certain types of resources within a shared territory, as they have developed complementary livelihood strategies. Also such nonexclusive land rights are established on the basis of traditional occupation" (ILO, 2009: 95).

Aside from national laws and the judiciary, and the international law of human rights, there is also a third legal system: the customary law(s) of Indigenous Peoples who have used it to organize their societies for millennia. Through the customary law, problems between community members have been solved, lands and natural resources managed, etc. It has been stated that Brazil faces a considerable challenge in redefining its legal system, incorporating customary law in its policies, and thus applying a new concept of the pluralism of society:

The contemporary concepts and values should pay attention to collective rights, autonomy, and responsibility of the states for protection of indigenous rights. ${ }^{17}$

The International Work Group for Indigenous Affairs (IWGIA, 2014, 180) has observed that the slow pace of Indigenous land registration is creating tensions between Indigenous Peoples and landowners (both small and large). The year

17 http://uanativenet.com/topicitem/Topics\%20In\%20Brief/234 (retrieved June 2015). 
2013 in particular was notable for growing Indigenous discontent, as the Indigenous leaders traveled twice to Brasília to protest the Proposed Constitutional Amendment (PEC 251). It is aimed at "transferring responsibility for the demarcation and approval of traditional lands from the executive to the legislature, in relation to Indigenous Peoples along with the creation of protected areas". (Ibid.) The IWGIA $(2014,180)$ claims that the small number of Indigenous lands (11) approved during Dilma Rousseff's (earlier) government reflects the growing strength of "anti-indigenist" policy compared to previous presidential administrations. The new amendment could pose a considerable threat for the Indigenous groups, since:

... most of the legislative seats are held by the Democratic Association of Ruralists, a party historically opposed to Indigenous Peoples. This manoeuvre could see Brazil regressing to colonial times or returning to an economy based on monoculture, with the extermination of the Indigenous population. In addition to PEC 251, other decrees are threatening the rights of the traditional peoples and communities ....In addition, there is Draft Additional Law 227, and other initiatives, on the part of both the executive and the legislature, that infringe the Federal Constitution and ILO Convention 169. This draft initiative aims to create an additional law related to Article 231 of the Federal Constitution - "on Indians" - highlighting exceptions to the Indigenous right of exclusive use of their traditional lands in cases of significant public interest on the part of the Union. Such exceptions include the exploitation of Indigenous lands by agribusiness, mining companies, and the construction of works linked to national, state and municipal interests. These exceptions could result in the extermination of a whole Indigenous people. A clear objective can be perceived behind these measures, namely the interests of the Ruralist Party combined with those of large mining companies, who are trying to circumvent Indigenous rights and lay hold of the power not to demarcate the country's Indigenous lands. (IWGIA, 2014, 181-183; emphasis original.)

President Dilma Rousseff's recent appointment of agribusiness advocate Kátia Abreu as the country's new agriculture minister has raised considerable criticism and concern among environmentalists and Indigenous Peoples ${ }^{18}$.

All things considered, the state itself can be considered the primary violator of Indigenous rights in Brazil. Failures to comply with the Federal Constitution and the ILO 169 aptly illustrate the government's position. In fact, the country's economic, environmental, and minority policies are highly contradictory. This is epitomized in the case of the "Growth Acceleration Plan," which aims at, for instance, harnessing the Amazon for national development by massive hydroelectric projects, like the Belo Monte dam complex.

Observed from a distance, the Amazon appears to be a huge, single forest unit. But when one zooms in on Google satellite images, the situation is alarming. Brown and gray patches can be observed; traces of human influence that are growing over time. Not only inland but also on the coast and throughout all South America, there is an accelerating decline in Indigenous Territories and natural parks, along with a spreading of extractive industries, highways, hy-

18 In his article, Watts (2014) contended that "Abreu is a leading figure in the 'ruralista' lobby, which prompted the government to weaken Brazil's forest code. In congressional debates and in her feisty newspaper column, she has called for more roads through the Amazon, congressional control over demarcation of indigenous reserves, more efficient monocultures, and the approval of genetically modified 'terminator seeds'." 
droelectric projects, and monocultures. As I compiled a socio-environmental conflict map ${ }^{19}$ with a list of Indigenous struggles (Map 3, Table 3), based on various web sources ${ }^{20}$, the picture started to evolve: throughout the continent, a plethora of Indigenous Peoples' current or recent struggles vis-á-vis multiple local, national, and global actors. Map 3 presents a sample of these most apparent conflicts in South America. It excludes numerous other conflicts related to cattle ranching, small scale logging, forest conservation areas, tourism, and drug trafficking, among others. What is also notable is that "green energy" may negatively impact Indigenous communities while the rural land is reorganized (e.g., Fernandes, Welch, and Gonçalves, 2010).

TABLE 3 A list of Indigenous Peoples' 21st-century struggles against large-scale industrial and infrastructure projects in South America.

\begin{tabular}{|l|l|l|l|}
\hline Country & Indigenous Peoples & Activity & $\begin{array}{l}\text { Company } \\
\text { /other actor }\end{array}$ \\
\hline Brazil & Kayapó and others & Belo Monte dam complex & Government \\
\hline Brazil & Guaraní-Kaiowa & Biofuel & Shell, Cosan \\
\hline Brazil & Truká and others & River transposition & Government \\
\hline Brazil & Awá & Logging & Logging gangs \\
\hline Brazil & Kayapo & Mining & Gold miners \\
\hline Brazil & Pataxó, Tupinambá & Pulp & Veracel \\
\hline Brazil & Tupinikim, Guaraní & Pulp & Aracruz \\
\hline Brazil & Karipuna and others & Hydroelectric dams & Government \\
\hline Brazil & Suruwaha and others & Oil/Gas & Petrobras \\
\hline Brazil & Arara and others & Hydroelectric dams & IBERDROLA \\
\hline Brazil & Xikrin & Mining & MinOnca Puma \\
\hline Brazil /Venezuela & Yanomami & Mining & Gold miners \\
\hline Bolivia/Brazil & Ayoreo and others & Oil pipeline & REPSOL \\
\hline Bolivia & Ava-Guaraní & Oil/gas & REPSOL \\
\hline Bolivia & Karitiana and others & Highway & Government \\
\hline Argentina & Wichí & Soy/cotton & Monsanto \\
\hline Argentina & Mapuche & Gas & REPSOL \\
\hline Chile & Mapuche & Hydroelectric dams & Endesa \\
\hline Chile & Mapuche & Hydroelectric dams & Endesa \\
\hline Chile & Mapuche & Pulp & Arauco \\
\hline Peru & Shawi and others & Oil & REPSOL \\
\hline & & & \\
\hline
\end{tabular}

(continues)

19 Cartographer Aliisa Priha made all the geographical maps, for which I provided background materials.

$20 \quad$ E.g., http://www.survivalinternational.org/;

http://amazonwatch.org/work/ defend-uwa-life-and-territory;

http://www.codpi.org/territorio-y-recursos-naturales/observatorio/mapeo; http:// www.atlanticrainforest.org/blog/?p=142; http://real-agenda.com/biofuelindustry-exterminating-guarani-kaiowa-people-in-south-brazil/;

https:/ / www.rainforest-rescue.org/petitions/769/brazil-violence-and-forcedeviction-for-biofuel; http:/ / www.ibtimes.co.uk/brazil-oil-giant-shell-gives-upcontroversial-352014; http://chevrontoxico.com/about/affectedcommunities/communities-mobilize-against-chevron; cf. Environmental Justice Organizations, Liabilities and Trade Atlas (http://www.ejolt.org/). (Retrieved June 13, 2015). 
TABLE 3 (cont.)

\begin{tabular}{|l|l|l|l|}
\hline Peru & Ashánika and others & Oil & REPSOL \\
\hline Peru & Nahua-Nanti & Gas & Int.consortium \\
\hline Peru & Murunahua and others & Logging & Logging gangs \\
\hline Peru & Quechua and others & Mining & Glencore X. \\
\hline Paraguay & Ayoreo-totobiegosode & Logging & Yaguarate Pora \\
\hline Colombia & U'wa & Oil & Occ. Petroleum \\
\hline Colombia & Wayuu & Mining & $\begin{array}{l}\text { Glencore,El } \\
\text { Cerrejón Mine }\end{array}$ \\
\hline Ecuador & Shuar and others & Oil pipeline & REPSOL \\
\hline Ecuador & Quechua and others & Oil & Petroamazonas \\
\hline Ecuador,Yasuní & Waorani and others & Oil & Multiple firms \\
\hline
\end{tabular}

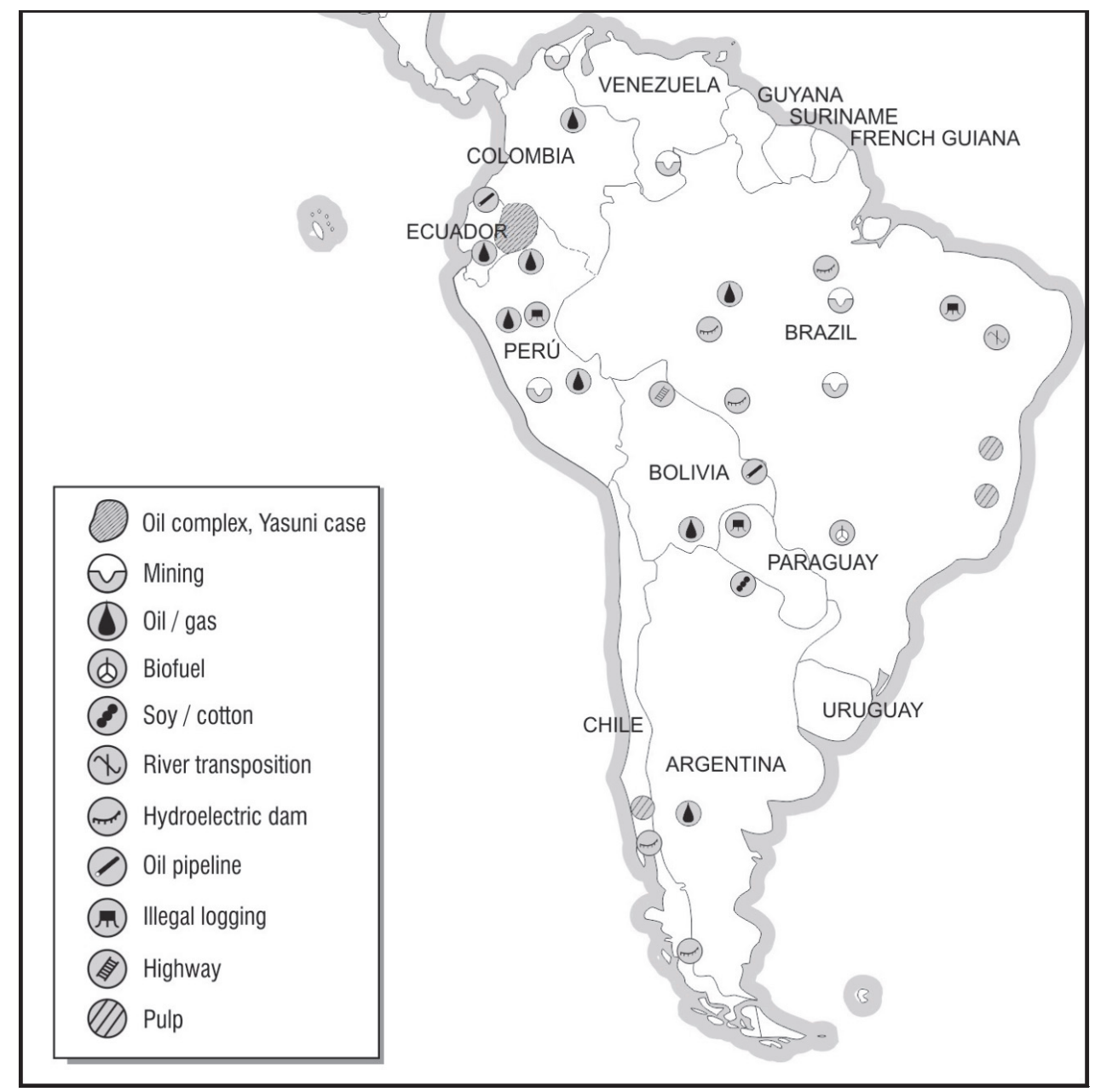

MAP 3 A map of Indigenous Peoples' 21 st-century struggles against large-scale industrial and infrastructure projects in South America. 
An ever-denser grid of land concessions and future reservations ultimately exposes the wretched situation: Indigenous and conservation areas, whether officially protected or not, are being commercially exploited by outsiders (see Map 4). The fate of the world's remaining tropical forests is intertwined with the fate of the Indigenous Territories (see Sutherland, 2003).
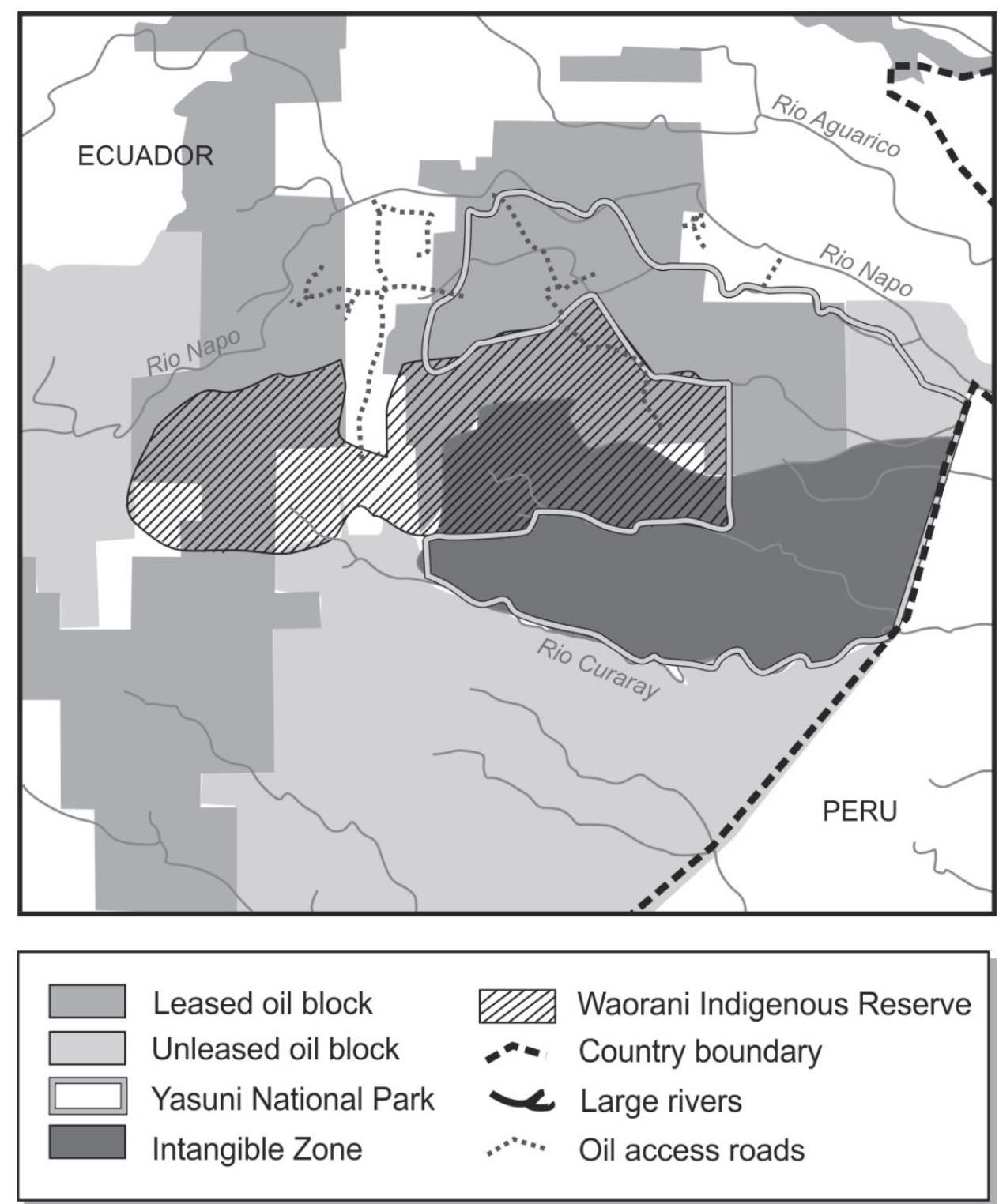

MAP 4

Overlapping and competing functions in Ecuador's Yasuní Man and the Biosphere Reserve (adapted from Finer, Vijay, Ponce, Jenkins, and Kahn, 2009) 
In 2013-2014, global social media was filled with news describing conflicts across Brazil. The latest Indigenous World report (IWGIA, 2014) confirms that 2013 was marked by tensions between Brazilian government policies and Indigenous rights. The most significant of these was the government's lack of commitment to demarcating the Indigenous territories, as well as the tensions created between the large landowners, small farmers, and Indigenous population. According to the report, the government's failures to comply with ILO Convention 169 are a clear example of the government's position with regard to Indigenous issues. In addition, the report states that there is a growing interest in mining companies and logging companies, and above all, in establishing hydroelectric power plants, as set out in the "Growth Acceleration Plan" that is being resisted by the Indians and environmentalists, among others.

Indigenous Peoples have not been passive in the face of external, global forces invading their lands; they have resisted by establishing social movements (see Gomes, 2000; Blaser, Feit, and McRae, 2004). We can assume that when an Indigenous Territory encounters diverse invasions simultaneously, this may weaken the land struggle, as the Indians must disperse their efforts. The invasions seem to proceed in such a way that not only do diverse actions occur at the same time, but some activities open the way to others.

A great deal of background - such as Indigenous political movements and organizations, the position of the religious institutions, the relationship between the Indians and the rest of the society, and the questions of Indigenous ethnicity and culture in Brazil and in South America - is outside the scope of this study (see also, e.g., Blaser, Feit and McRae, 2004; Gomes, 2000; Virtanen, 2007). Here I have offered a more general outlook on the political economy context, to show the environment in which modern land struggles arose. In my research articles I have attempted to describe some of the most important events in regard to the three Indigenous groups, also in relation to their cultures. I will next describe the fieldwork areas and actors, as well as my research methods and materials.

\subsection{Research arenas and approach}

\subsubsection{Pulp production in the Atlantic Forest domain}

Mata Atlântica and Amazonia have different conservation approaches: Amazonia is one of the remaining large forests while Mata Atlântica is among the most threatened forests in the globe. The Brazilian economy is depending on the Mata Atlântica for various reasons: for instance, if water resources are not sustained, the whole Brazilian economy will collapse. So it is important to protect this forest not only in ethical and economic terms, but also in social and cultural terms - at the national and global level. (Lino, personal communication, 2004.)

It is an alarming development, not only for Bahia or Brazil, but for the entire planet, that within only 30-40 years, the natural forests were destroyed here, so that we have only 3-5 percent left of Mata Atlântica. In the 1970s they started to build a bigger road from Ceará to Rio, and from Espírito Santo came the loggers who rapidly cleared the 
forests. Then the cattle ranchers arrived, and finally the cellulose companies. And now we are witnessing the same type of 'fishbone' 21 development in Amazonia. (Reed, personal communication, 2006.)

As the very foundation of Brazilian society-determined by the Europecentered world order-remained unchanged for long, so did the forces of deforestation. Today 120 million inhabitants -60 percent of Brazil's populationis concentrated on Brazil's Atlantic coast; the area includes the country's largest cities, such as São Paulo, Rio de Janeiro, Salvador, and Recife. The Atlantic Forest $^{22}$ domain stretches across 3,517 municipalities in 17 states. Before Portuguese colonization, the Atlantic Forest was 1.3 million $\mathrm{km}^{2}$ (15 percent of Brazil). As of today, over 95 percent of the Atlantic Forest cover has been lost due to intensive human activities, and the remainder is dwindling due to the cutting of timber, pulp and fuel production, illegal extraction of plants and animals, introduction of exotic species, aquaculture, uncontrolled urban expansion, industrialization, and immigration. Urban consumption and trade in particular have become the main driving forces for deforestation in this century. (Dean, 1995; Araujo et al. 1998; Galindo-Leal \& Camara, 2005; Laakkonen, 1992; Butler, 2014.) (See Map 5.)

Estimates of how much Atlantic Forest remains vary depending on the methods and indicators used. The overall situation is alarming. According to Ribeiro, Metzger, Martensen, Ponzoni, and Hirota (2009), more than 80 percent of the fragments are $<50 \mathrm{ha}$; almost half the remaining forest is $<100 \mathrm{~m}$ from its edges; and the average distance between fragments is large $(1,440 \mathrm{~m})$. Nature reserves protect only 9 percent of the remaining forest and just 1 percent of the original forest. However, the authors' estimates of existing Atlantic Forest cover were higher than previous ones, ranging from 11.4 to 16 percent. What is noticeable that the differences among estimates are mainly related to the inclusion of intermediate secondary forests and small fragments $(<100$ ha), which correspond to approximately $32-40$ percent of what remains. The authors propose that when planning biodiversity conservation, the clear differences in the amount remaining and its spatial distribution within each sub-region must be considered.

\footnotetext{
21 This refers to the formation of roads that open the way for cattle ranchers, loggers, corporations, and human settlements.

22 Previously it was called the "Atlantic Rainforest"; however, "Atlantic Forest" is a better name, since it refers to the whole biome of the region, including the associated ecosystems (Lino, personal communication, 2004).
} 


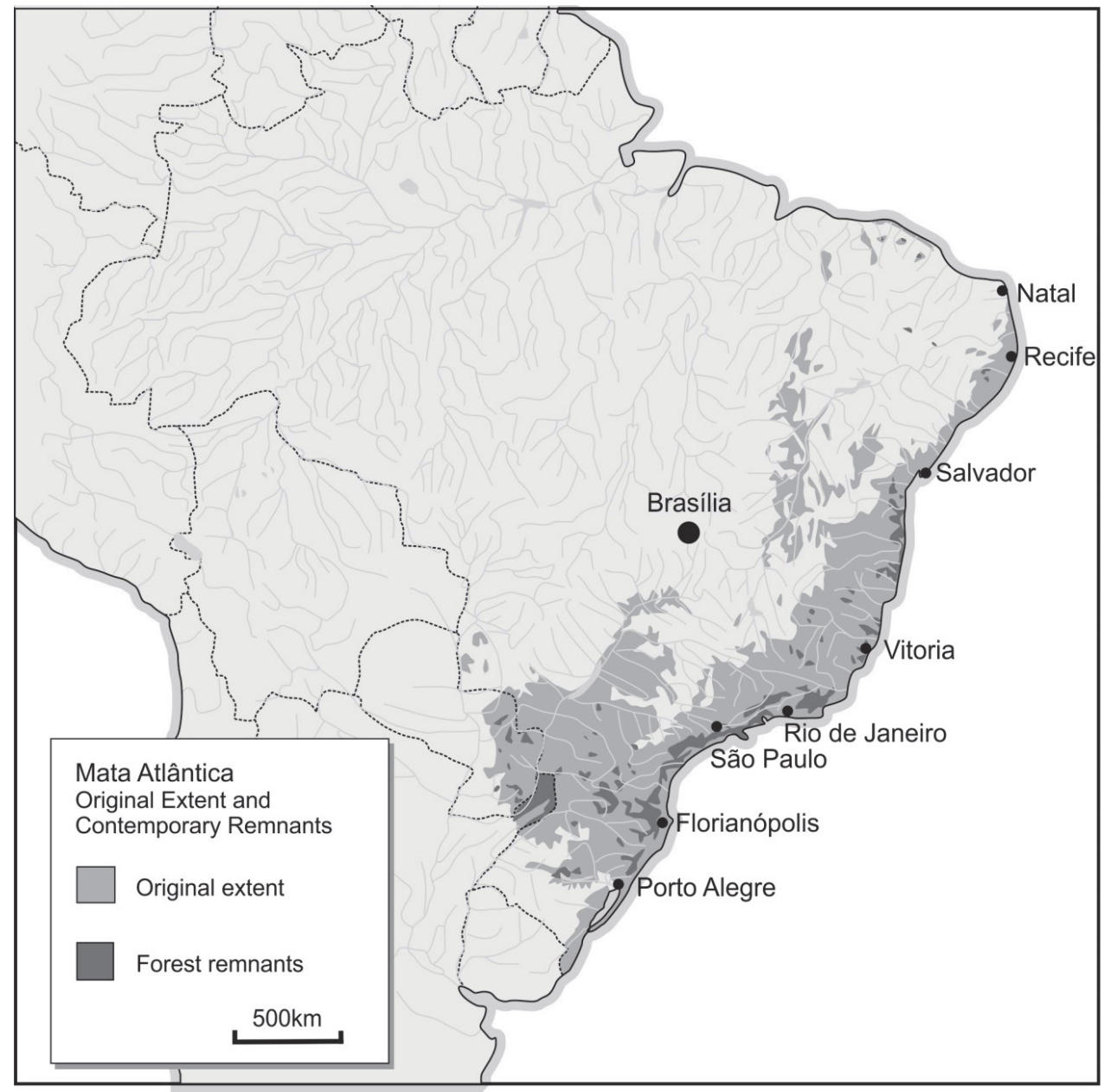

MAP 5 The original extent of the Atlantic Forest and the current remnants (adapted from SOS Mata Atlântica Foundation/INPE 2008).

Spanning over 4,000 $\mathrm{km}^{2}$ from the northeast to the south of coastal Brazil (and also reaching Paraguay and Argentina), the Atlantic Forest is isolated from other large forest formations - the Amazon Forest and Andean forests - by the dry vegetation of the Brazilian Planalto (Caatinga, Cerrado and Pantanal) and by the Chaco in the central depressions of South America (Silva and Casteleti, 2005). The Atlantic Forest is a typical neotropical forest, which has a multitude of different biomes (Diegues, 1994).

The pace of deforestation of the Atlantic Forest has been extremely rapid, given its history as Brazil's oldest forest formation: this vast biome has been forming for at least 70 million years (Leitão-Filho, 1987). What is left of the once-magnificent forest domain is a chain of small forest islands. The vast Amazon has attracted most of the public attention, leaving the Atlantic Forest all but forgotten. Nevertheless, the Atlantic Forest's historical geographic isolation 
has enabled the development of a unique mosaic of biota, with a high level of endemism (Rizzini, 1997). Even today, new animal and plant species are constantly being discovered in this UNESCO Biosphere Reserve. According to scientific estimates, today's Atlantic Forest possesses from 1 to 8 percent of global biodiversity. To cite some examples, it has 20,000 species of plants, of which 40 percent are endemic, i.e., cannot be found anywhere else. Indeed, 92 percent of its forest amphibians are not found anywhere else on earth ${ }^{23}$ (see Mittermeier et al., 2004). An extensive study of 94 Protected Areas (PAs) targeted for mammal conservation in the Atlantic Forest region found that one critical biodiversity concentration was located in Bahia state, which was named as an endangered ecoregion. The study recommended that policy-makers and conservationists identify the most critical areas in order to enhance the flux of biodiversity between diverse landscapes and to ensure the connectivity between PAs to increase biodiversity protection and conservation, especially concerning endangered species. (See Albuquerque, Assunção-Albuquerque, Gálvez-Bravo, Cayuela, Rueda, and Benayas, 2011.) Thus due to its high endemism on a global scale, the Atlantic Forest is one of the world's 34 global "biodiversity hotspots" - and this extraordinary, fragile position constitutes an important context for discussing pulp production within this eco-region, particularly within Bahia state.

My first encounter with the Atlantic Forest took place in 2004, when I traveled by boat and then foot to Cardoso Island State Park, at the southern peak of São Paulo state. The concurrence reminded me of the uniqueness of this ecological entity - a complex web of diversified ecosystems between varied natural forest types, the coast and the sea, like here in the restinga forest (see Image 2):

I visited Ilha do Cardoso State Park with a group of ornithologists - three Finns and one Brazilian - who were collecting data for their guidebook on birds. A local Caiçara Indian guided us as we departed by boat in the early morning darkness to search for a tree canopy where the blue-cheeked parrots, Amazona brasiliensis, had their sleepover in the wetland. There were only 3,000 individuals remaining of this endemic species. When we arrived, the birds started fleeing their big tree in pairs, loudly squawking and heading for breakfast on another forest island. The black eyes of tiny yellow frogs peeked from the miniature pools that the rain had left in the hearts of red bromeliads. The flower and the frog had a symbiotic relationship and formed a micro-ecosystem. (Field notes, 2004.)

Hence my research project on the role of the Finnish forest cluster in pulp production actually commenced from this border between the states of São Paulo and Paraná, when doing fieldwork for a postdoctoral research project, funded by the Academy of Finland, on the governance of the Atlantic Forest Biosphere Reserve. In all, the previous and the current field research involved roughly $9,220 \mathrm{~km}$ of intensive travel by bus and car back and forth along the coast in 2004 (twice), 2006, and 2011, between the Cardoso Island State Park (SP), and Salvador (BA).

23 http://wwf.panda.org/about_our_earth/ecoregions/atlantic_forests.cfm (retrieved June 2, 2015). 


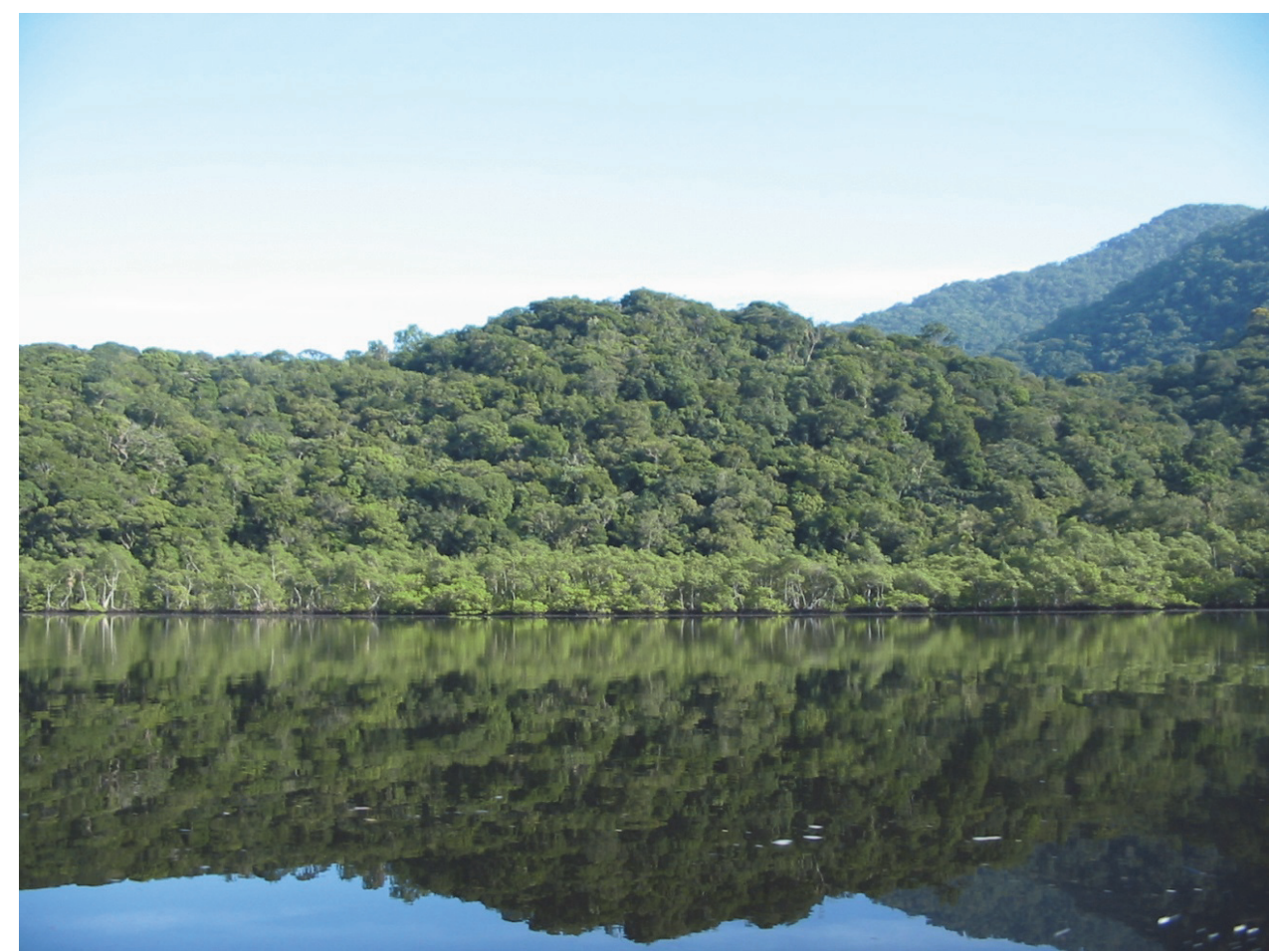

IMAGE 2 Cardoso Island State Park (Photo: Susanna Myllylä).

In my previous research project, I interviewed national and state-level park authorities, the management of the Atlantic Forest Biosphere Reserve and its regional co-ordinators, local environmental police, private firms running sustainable forestry practices, conservationists, environmental lawyers, civic organizations, social movements, and particularly diverse local communities that were affected not only by conservation areas, but also by corporations and development projects. I also flew to the interior of the country, to Brasília, to interview representatives of the Ministry of the Environment/IBAMA, FUNAI, and some international civic organizations. I was interested in how various traditional communities could live within official conservation units, and what kind of sustainability and livelihood issues existed. These travels to various conservation areas and villages also illuminated the scale of the growing human pressure on the Atlantic Forest. Among the interviewed local communities were the Caiçara Indians and the Guaraní Indians of Cardoso Island State Park (São Paulo); the Caiçara Indians of Pariquera-Açu (São Paulo); the Afro-Brazilian Quilombos of Ribeira Valley (São Paulo); favela ("slum") communities (Rio de Janeiro); and the most relevant groups regarding the study at hand, the Tupinikim and the Guaraní Indians (Espírito Santo) and the Pataxó Indians (southernmost Bahia). What I found was a large number of socio-environmental conflicts between national/state-level conservation units, corporations, development projects, and local people. Finally, when coming across vast eucalyptus fields in Espírito San- 
to and Bahia, and local communities encapsulated by monoculture plantations designed, owned, and equipped by the Finnish companies, I decided to focus further research solely on this topic and to figure out what was going on in this "remote" region, seen from the Northern viewpoint.

Meeting the IBAMA and FUNAI representatives first in the capital city provided me with some perspective, allowing me to juxtapose the authorities' views with the local experiences of the Tupinikim, the Guaraní, and the Pataxó. The latter group in particular had become a critical target for conservation authorities, since the villages of the Indigenous communities were partly located in Monte Pascoal National Park, or rather, the park itself was actually situated within the Indigenous Territory. The Pataxó have extracted much of the hardwood from the park for handicrafts, as one NGO staff member told me. However, they are paid only about three reals ( 0.81 euros) per item by the dealers coming from Rio, who sell the beautiful wooden pieces for ten to twenty times more money. It is not surprising that IBAMA has suggested a co-management of the park with the Pataxó since it is situated within the Indigenous Territory. The Indians have a full right to use its resources.

As a result, there has been a complex set of land disputes between diverse actors. And now there was a relatively new actor and a major landholder with its partners on the scene: Veracel Celulose and the Finnish forest cluster representatives. In addition, there are many other pulp companies, like Suzano or Bahia Pulp, operating in the region.

My primary fieldwork sites were in the two states where deforestation and other massive land shaping had taken the heaviest toll. Hence not surprisingly, pulp companies often argue that the region was already deforested prior to eucalyptus plantations, in other words, that they do not have a role in this development-an issue that will be analyzed in detail later in this chapter. Producing eucalyptus is a very profitable business in the region: trees reach their full height (35 meters) within just seven years and can be harvested, processed, and transported globally from the strategically located ports. The partner corporations are the world's largest producers of bleached eucalyptus pulp: the Brazilian Fibria Celulose S.A. - previously Aracruz Celulose S.A., which incorporated with its rival, Votorantim Celulose e Papel, in 2009-and the SwedishFinnish Stora Enso. In 2005, the partners opened Veracel Celulose S.A. in the southern part of the state of Bahia, in the municipality of Eunápolis. Valued at USD 1.25 billion, Veracel was the biggest investment project during the Lula administration: the Nordic Investment Bank (NIB), the European Investment Bank (EIB), and the Brazilian Social and National Development Bank (BNDES) financed USD 640 million for the pulp mill. NIB financed USD 70 million and EIB USD 80 million of this sum (Andersson \& Bartholdson, 2004, 5).

Before we take a closer look at Veracel, a brief introduction of the owners is in order. Fibria/Aracruz, with its four mills, has the capacity to produce 5.3 million tons of pulp annually. The company owns 969,000 ha of land, of which 343,000 ha are native forests, spread across six states: Bahia, Espírito Santo, Minas Gerais, São Paulo, Mato Grosso do Sul, and Rio de Janeiro. The company 
closed the year 2014 with EUR 47.32 million net income, which allowed a minimum of nearly EUR 11 million in shareholder dividends ${ }^{24}$. Regarding Fibria's partner, the annual production capacity of Stora Enso is 5.6 million tons of pulp, 7.1 million tons of paper, 3.8 million tons of board, 1.3 billion square meters of corrugated packaging, and 5.6 million cubic meters of sawn wood products. Stora Enso operates in 35 countries. The company sales in 2014 were EUR 10.2 billion, net income EUR 810 million, and dividends to shareholders were EUR 237 million. 25

Veracel Celulose is a 50/50 joint venture between Fibria/Aracruz and Stora Enso. Veracel's history started in 1991, when Veracruz Florestal (a subsidiary of Odebrecht ${ }^{26}$ ) acquired land in Bahia, and the first eucalyptus seedlings were planted. Industrial operations are concentrated at Veracel's mill, located between Eunápolis and Belmonte. Company administration and other functions are located in Eunápolis. The mill started with an annual production capacity of 900,000 tons of bleached eucalyptus kraft pulp, a raw material used in manufacturing tissues and paper products for printing and writing. Veracel has the capacity to produce 24 million eucalyptus cuttings a year, and according to the 2014 Stora Enso financial report, the annual production capacity of Veracel pulp mill is 1.1 million tons. Both owners are entitled to half of the mill's output. In addition, the company owns a sea terminal situated in Belmonte, from where all production output is first shipped to Espírito Santo's Portocel port, owned by Fibria/Aracruz, and from where pulp is loaded on ocean-going vessels and taken to Stora Enso's European factories. The majority goes to Oulu factory in Finland. Veracel owns a total of 234,676 ha of land, of which 92,744 ha are eucalyptus plantations, in addition to 23,000 ha of outsourced plantations through contracts with the local farmers. The Veracel Station Private Reserve of Natural Heritage covers 6,069 ha of preserved native forest.

The company operates in 10 municipalities: Eunápolis, Belmonte, Porto Seguro, Guaratinga, Itapebi, Canavieiras, Santa Cruz Cabrália, Mascote, Itabela, and Itagimirim. Veracel has sought to massively expand its plantations. In 2012 the company was granted an environmental permit (valid for four years) to double plantations and cellulose production capacity, with nominal production capacity of 1,500,000 tons per year, side by side with the company's current production line. The permit also allowed the forest base to cover not only the previous municipalities but also some new ones: Encruzilhada, Itapetinga, Itarantim, Maiquinique, Macarani, and Potiraguá.

Veracel is a combination of international divisions from Europe, China, North America, and Brazil. The Finnish consulting firm Jaakko Pöyry (currently Pöyry) has had contracts in many of the pulp and paper factories in Brazil27; it

\footnotetext{
24 http://www.fibria.com.br/web/en/midia/releases.htm (retrieved July 18, 2015).

25 http://www.storaenso.com/about;

http://www.storaenso.com/About-Site/Pages/Stora-Enso-in-brief.aspx;

http://assets.storaenso.com/se/com/DownloadCenterDocuments/Financial_Report 2014.pdf\#search=shareholder (retrieved August 2, 2015).

26 A Brazilian business conglomerate consisting of diversified sectors.

27 Marchak, 1995, 300.
} 
has been involved in various stages of planning and construction, both in Fibria/Aracruz and Veracel. Pöyry has prepared the feasibility and technical reports for the operations. ${ }^{28}$. In addition, Kvaerner Power, and Metso Automation of Tampere, Finland, produced equipment for the factory. Finnvera and its subsidiary, the Finnish Export Credit Ltd., have provided financing for these Finnish companies. According to Finnvera, it "provides financing for the start, growth and internationalization of enterprises and guarantees against risks arising from exports" 29 . Hence in addition to multiple financial institutions, the role of other companies within the Finnish forest cluster has been notable and highly profitable from the beginning. (Image 3.)

28 E.g., http://www.poyry.com/projects/veracel-celulose-sa-brazil (retrieved July 18, 2015). 29 https://www.finnvera.fi/eng/Finnvera/Finnvera-in-brief (retrieved July 18, 2015). 


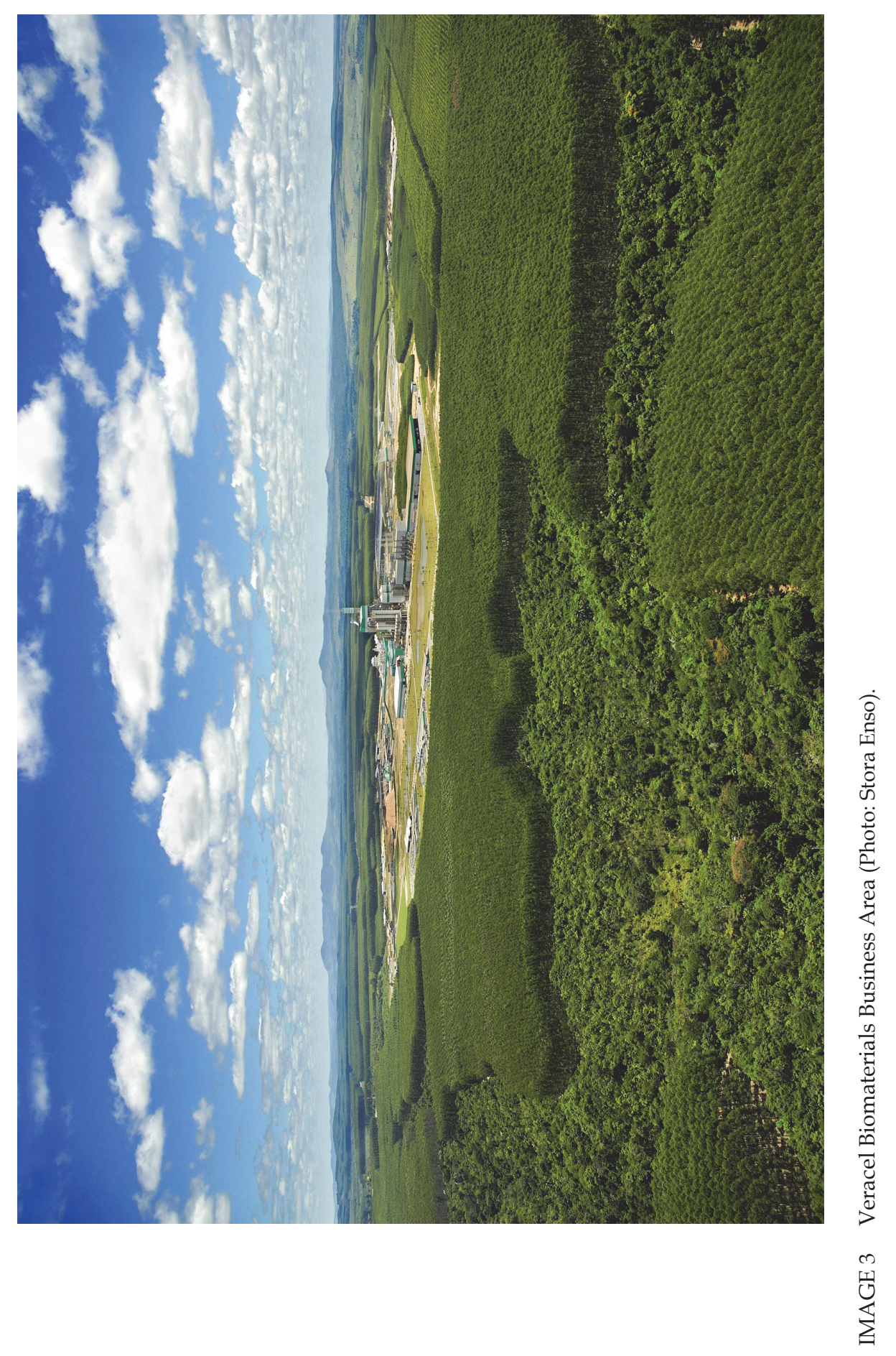


As part of the green or sustainable corporate image construction, there have been efforts to contribute to the conservation of the Atlantic Forest. For instance, the Veracel Station Private Reserve of Natural Heritage is an important forest island for biodiversity conservation. On the other hand, the authorities also demand a minimum of 20 percent natural forest coverage on the company's land, and the company must obey other environmental regulations (IBAMA, personal communication, 200430). According to Stora Enso (2014), Veracel had planted rainforest species on more than 5,100 hectares by 2013. The eucalyptus plantations are FSC-, Cerflor-, and PEFC-certified ${ }^{31}$, and therefore, according to Veracel's website, the company respects the environment and the nearby communities ${ }^{32}$. In addition, Fibria/Aracruz and Stora Enso are participants in "the New Generation Plantation," launched by the World Wildlife Fund. The program is aimed at supporting the restoration and connection of Atlantic Forest remnants ${ }^{33}$.

Despite the companies' efforts to become greener, the environmental, economic, and social sustainability of pulp production are constantly challenged by various civil society actors. For example, Veracel's FSC certificate has often been questioned, since there is evidence that the certification process was not conducted in accordance with the FCS rules. Nevertheless, this incident did not affect the company's certificate (see Lang, 2012).

Representing the most powerful landholders, pulp companies have an inherent tendency to cause or be intertwined with various land disputes in the region where Brazil's poorest residents live. Discrimination and violence, typical features of Brazil's development path, have also characterized the pulp history on Brazil's Atlantic coast and left an indelible mark on people's collective memories. In Espírito Santo state in the 1960s, Fibria/Aracruz, with the protection of the military government, felled native rainforests and evicted a majority of the Tupinikim Indians. All that is left now is thin patches of Atlantic Forest by the riversides. The remaining Tupinikim started to claim their ancestral lands with the support of the Guaranís. However, Fibria/Aracruz kept suppressing Indian uprisings throughout the 40-year land dispute, which accelerated in 2005-2006. In 2007 Brazil's minister of justice signed two decrees declaring 18,070 ha of land to belong to the Tupinikim and Guaraní Indigenous Territory. Fibria/Aracruz had to withdraw and pay the Indians compensation. The company ultimately harvested its eucalyptus within the IT, leaving behind a desert of stumps and a multitude of environmental, social, and economic problems (see Map 6).

30 If originally aligned with a natural forest, river and creek, the plantation should have natural forest buffer zones ranging from 30 to several hundred meters in width. A pulp company is allowed to cover a maximum 20 percent of each inland municipality, and a maximum 15 percent of coastal municipalities with plantations. (Andersson \& Bartholdson, 2004, 27.)

31 Forest Stewardship Council (FSC) and Programme for the Endorsement of Forest Certification schemes (PEFC).

32 http://testemu.insix.com.br/en/our-operations/industrial/pulp-production/ (retrieved July 18, 2015).

33 http://newgenerationplantations.org/multimedia/file/12b486cb-ea24-11e3-9f9e005056986313 (retrieved July 18, 2015). 


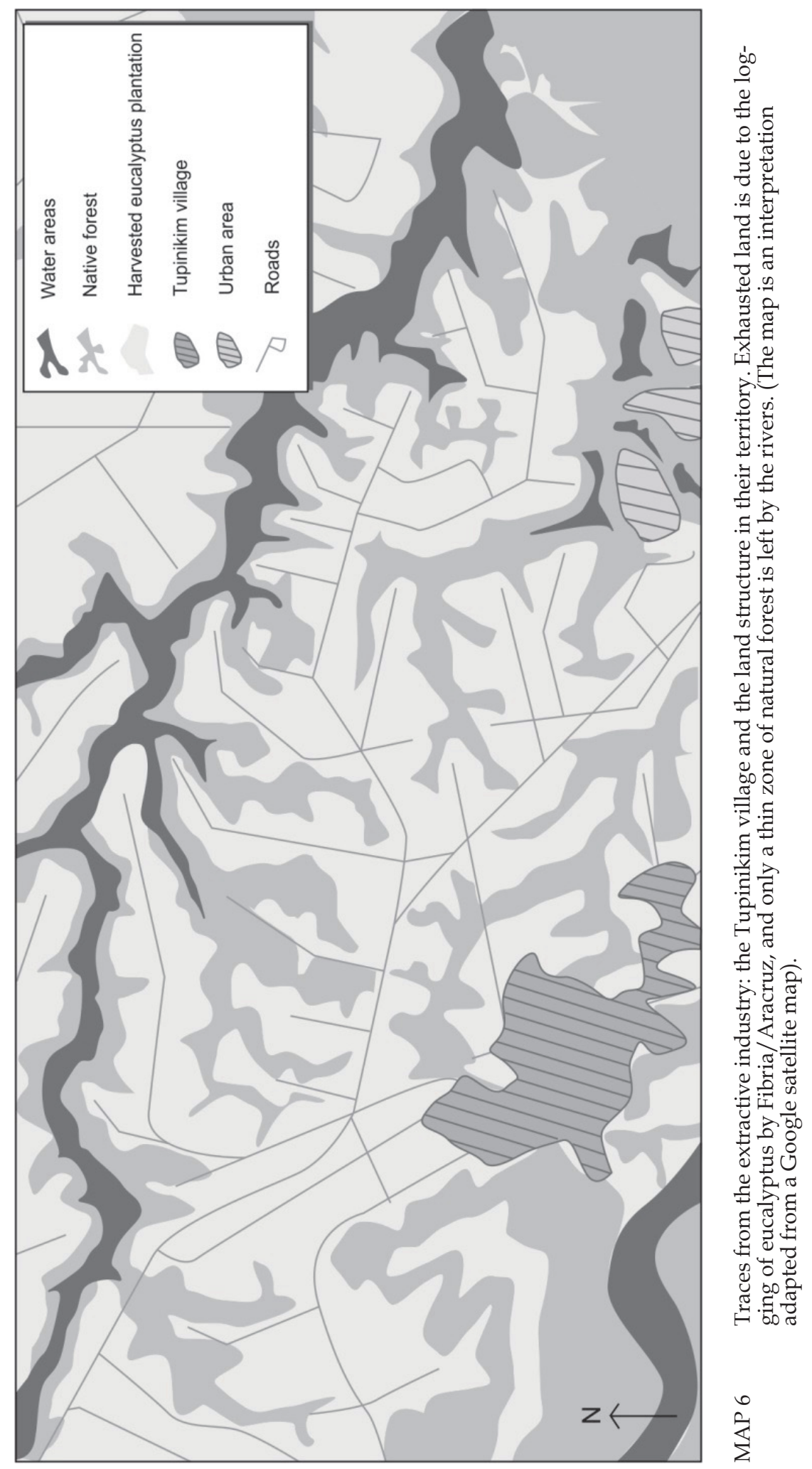


In the north, in Bahia state, the Pataxó people and Veracel have had different views on their territories and the environmental impact of the pulp factory and plantations. Since the construction of the pulp mill in Eunápolis city, this land dispute has been manifested in Indigenous protests and legal complaints against Veracel. The Pataxó Indigenous Territory is waiting for official registration at its total size, 52,000 ha. The land struggle also seems to have become a long-term phenomenon; it has now taken more than 10 years, while the IT registration procedure has lasted over 16 years (since 1999).

Veracel was also responsible for anti-environmental acts early in its history. In the early 1990s, when Odebrecht ${ }^{34}$-then called Veracruz Florestal Ltd was the owner - the company illegally logged some natural forests. The Brazilian environmental authorities stopped further geographical expansion of the company by 1993 (Andersson \& Bartholdson, 2004, 33). Hence the pulp industry has also inevitably contributed to the historical deforestation of the Atlantic Forest - all of which is entangled with the situation of the Indigenous Peoples.

Some of the environmental authorities believe that plantations are obstructing critical ecological corridors and thus regeneration of the Atlantic Forest, as they stated during my fieldwork interviews. Furthermore, a disconnect is visible between environmental policy and economic policy, not only in the coastal area but in the whole country. The political sensitivity in the pulp industry was demonstrated during an interview I was conducting at the Environmental Institute of Espírito Santo state in 2004. After a discussion of the Atlantic Forest ecological corridor project (which actually covers the entire state), I was suddenly asked by a staff member to switch off my voice recorder when the conversation turned to Fibria/Aracruz and its impact as a barrier on the ecological corridor's development. It thus became apparent that there was an unspoken but striking contradiction between economic and environmental policies and that the latter was subordinate to the former. Despite ineffective attempts to regulate Fibria/Aracruz, the state strongly supported the presence of a company that evaded mandatory environmental licenses; a proper land zoning, recovery of rivers, and establishment of forest conservation areas. Some of the local NGOs, in turn, washed their hands of this corridor project, since their emphasis was on the Indians' human rights. As one NGO staff member remarked critically:

They are conservation puritans, city people, using only biological criteria, and do not consider Indigenous Peoples who cannot take part in this debate. Corridors are not sufficient as such, since they are not based on social, but mere technological solutions. The conservationists should work with people who have historically lived in Mata Atlântica.

$34 \quad$ A Brazilian business conglomerate consisting of diversified sectors. 
Concerning the land struggles between companies and Indigenous Peoples, some Brazilian academics believe that the result of the Fibria/Aracruz case may serve as a precedent for Veracel's case in Bahia, after the registration of the Indigenous Territory is finalized. Bahia has a different background, since its natural forests have faced a drastic decline since the colonial era. However, to this day there are important forest conservation areas, such as the three national parks (Monte Pascoal, Descobrimento, and Pau Brasil), which brings up one more actor involved in land disputes: the government's environmental authority IBAMA. Bahia has numerous biologically significant forest islands, which are largely untouched due to their barely accessible location on steep slopes or mountainous areas, unsuitable for eucalyptus production. (Images 4 and 5.)

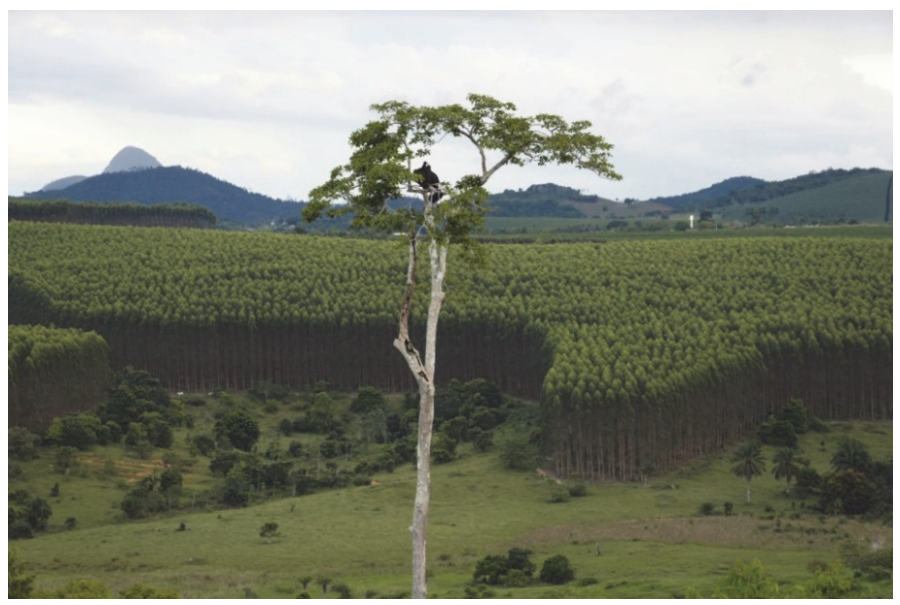

IMAGE 4 Eucalyptus field (Photo: Susanna Myllylä).

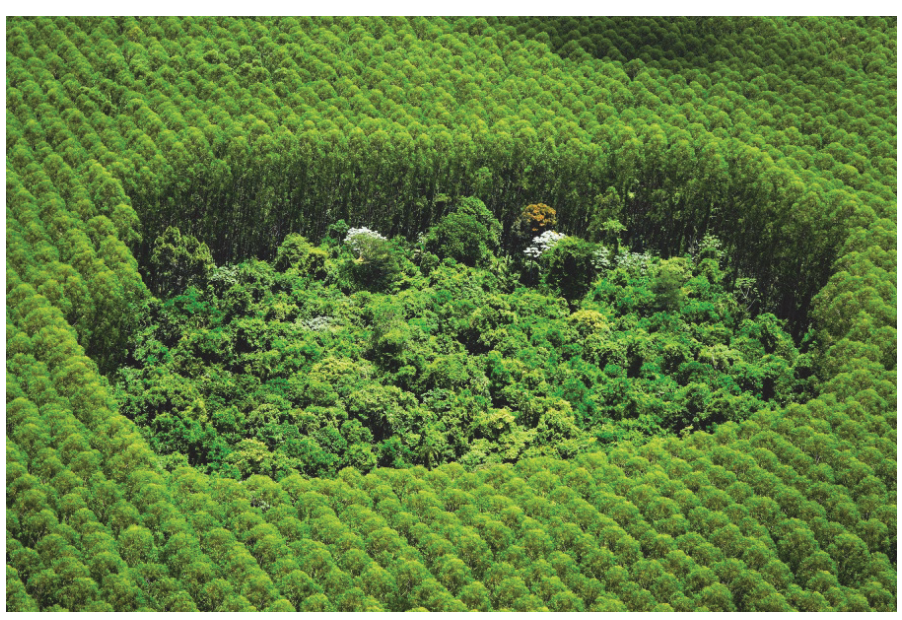

IMAGE 5 Veracel Biomaterials Business Area and a rainforest (Photo: Stora Enso). 


\title{
2.4.2 Getting in, getting on, getting out, and getting back ${ }^{35}$
}

What follows in this chapter is a critical self-reflection on the employed research methodology, materials, and the research field, with specific attention to the issues that may be useful for other researchers working on a similar topic.

Since my primary research objective was to learn what Indigenous Peoples see as significant in CCR, a multi-disciplinary qualitative research methodology was used, by combining case study (Yin, 2003) with the Grounded Theory (GT) and field ethnography approaches. To a minor extent, discourse analysis was used in interpreting the research data. The ethnographic field research material is based on individual and group interviews, including the collection of oral histories among the three recognized Indigenous groups. In regard to the wider context of the studied phenomenon, my task was to offer an interpretation of how micro-level phenomena are related to macro-level phenomena. That is, I wanted to explain what kind of understanding and long-term experiences the Indigenous communities have regarding corporations located in their neighborhoods and lands, and the attachments of those firms to Brazilian society. I have collected personal and communal memories and observations of the Indigenous persons since the beginning of the land struggles: the 1960s (Espírito Santo) and the beginning of 2000 (Bahia). Magnússon and Szijártó (2013) aptly define the objectives in microhistory:

\begin{abstract}
Microhistorians hold a microscope and not a telescope in their hands. Focusing on certain cases, persons and circumstances, microhistory allows an intensive historical study of the subject, giving a completely different picture of the past from the investigations about nations, states, or social groupings, stretching over decades, centuries, or whatever longue durée. Similarly to classical Greek plays, where we can find a threefold unity of place, time and action, the microhistorical approach creates a focal point, collecting the different rays coming from the past, and this lends it a real force. Microhistory, however - and this is the second and not any more evident element of its definition-has an objective that is much more far-reaching than that of a case study: microhistorians always look for the answers for "great historical questions" ... when studying small objects. ... And finally, the third main feature of microhistory ... is the stress put on agency. For microhistorians, people who lived in the past are not merely puppets on the hands of great underlying forces of history, but they are regarded as active individuals, conscious actors. (Magnússon and Szijártó, 2013, 4-5.)
\end{abstract}

Hence my research is also fundamentally about collecting microhistories, "rays from the past," offering a different narrative not only on economic development in Brazil but also on the success stories of Finnish firms in South America.

During the 2004 and 2006 fieldworks, I concentrated on the case study approach by collecting ethnographic material on Indigenous perceptions on pulp production and by analyzing land struggle tactics - the discourses and practical actions employed by both sides. The first and second research articles of the dissertation tackle these issues. In addition, the "entanglement" of the Finnish firms in the land struggles was introduced. The interviewees perceived the land struggle not merely as a question of the company community relations but

35 The phrase is from researching organizations by Buchanan, Boddy and McCalman (1988). 
more comprehensively: the relationships had penetrated to the identities, cosmologies, and nature relationship of the Indians. The long-term land struggles had emerged due to the lack of clear ethical rules guiding or regulating companies in their approach to new investment regions inhabited by a stakeholder group - and not an ordinary one, but with specific land rights: the Indigenous Peoples and their traditional territories. Realizing that there was a serious lack of understanding and knowledge on the dynamics between the two actors led me to seek a creative research methodology for generating a theoretical model and, concurrently, policy recommendations.

Hence, this time I ended up with a reverse research strategy by applying the Grounded Theory approach, which I tested when accomplishing the last fieldwork phase in 2011. I wanted to develop a theoretical conceptualization - a CSR model-grounded in case studies. The data-based inductive method and the formation of conceptual categories were the elements I adopted from the GT. Also, I dealt with the extant literature mainly after the empirical material, in later stages of the research process. The results from this research phase are presented in the third article of the dissertation. I would consider this approach relevant, since my research task was to examine a previously little-studied subject. Another advantage of the GT is that rather than relying on pre-existing conceptualizations, it allows the inductive construction of abstract categories developed from data. Additionally, it offers space to create a new theoretical framework or model, rather than simply verifying or disproving an existing theory. The expectation is that the majority of the literature review is conducted after the new theoretical framework starts to emerge, because the literature is expected to take a secondary role, and thus it is integrated into the study as data. In addition, certain benefits can be found in combining the GT method with the case study method. (See Fernández, 2004; Urquhart and Fernández, 2006; Strauss and Corbin, 1990, 49-50.)

According to the GT principles, my goal was to carry as few preconceptions about the theoretical elaborations as possible before collecting empirical material. Through the previous fieldwork, I obtained a basic knowledge of Brazilian society, the situation of the communities, and the basic CCR questions. However, when I processed the extant literature after collecting the empirical data, I realized that the GT approach entailed one structural dilemma. Although my approach was not to have an overly strict list of questions for the interviews, better knowledge of the international background cases before the fieldwork would have advanced my research questions. This finding also demonstrates that although I did not find a sufficient theoretical construction in the extant literature to analyze the CCR, the core elements (asymmetry and tactics of actors, corporate influence on livelihoods and environment, government's policies, etc.) emerged quite identically in the international case studies with diverse contexts. Thus we are basically looking at the same phenomenon of extractive industries or extractive capitalism, but from different angles. Despite my criticism, the GT approach as an adapted research methodology was ideal for the topic of this study, since there has been little exploration of the Indigenous experience with- 
in a wider context, i.e., the socio-environmental conflict with the corporations, and the dynamic relationships between the communities and corporations, manifested as a land struggle.

Furthermore, using a survey in this research would have resulted in missing a considerable part of the research results. In this work it was necessary to listen to what people had to say and to collect their narratives, most of which could not be captured from desk study or from pre-structured surveys. (The latter might even have meant using expressions that the respondents would find incomprehensible.) Hence although I usually presented a set of thematic questions, at times I turned on the minidisc recorder and asked a single question, such as: what do you know about Veracel and Stora Enso? It turned out that people had long stories to tell and a quite clear impression of what was going on. An example of an issue not usually attached to CSR discourses in the South, and that would have been passed by without an ethnographic approach, is the internal dynamics of the communities: how the corporations influence the relations between villages and even within individual family units. Deepening the latter topic - brought up by women in particular-would be one of the interesting issues for further research. In addition, Indigenous territories are usually considered communal lands, but my study did not include the examination of power issues related to land tenure and management question, within the community, or regarding gender.

During my 2004 and 2006 fieldwork in Espírito Santo state, in the municipality of Aracruz, 2,552 Tupinikim and 213 Guaraní, that is 2,765 Indigenous persons, were living in a total of seven villages. The Tupinikim aldeias were Caieira Velha, Comboios, Pau-Brasil, and Irajá, while Boa Esperança, Três Palmeiras, and Piraquê-açu belong to the Guaraní. Their communal territory, confirmed by the minister of justice, covered 7,061 ha at that time, while the land struggle was about the remaining 11,009 ha of the Indigenous Territory (18,070 ha) identified by the FUNAI researchers. At present, the official Tupinikim-Guaraní Indigenous Territory (or the Tupinikim IT) is 14,282 ha in size, and its total population is estimated at 2,464 people ${ }^{36}$, less than during my fieldwork. The Guaraní tribes are the Guaraní-Mbya and the Guaraní-Nandeva. In Bahia state, in the municipalities of Porto Seguro, Santa Cruz Cabrália, Itamarajú, and Prado, the Pataxó population in 2011 was roughly 5,600 people, who lived in 14 aldeias ${ }^{37}$ : Trevo do Parque, Guaxumá, Pé do Monte, Boca da Mata, Barra Velha, Meio da Mata, Aldeia Velha, Coroa Vermelha, Nova Coroa, Mata Medonha, Juerana, Jaqueira, Aroeira, and Jitai. The officially registered Indigenous Territory was 8,627 ha, while the entire Indigenous Territory was identified by FUNAI as be-

36 Some differences can be found in FUNAI's numbers. The most recent statistics indicate a steady increase in the Indigenous population, rather than a decline.

See, e.g., http:// pib.socioambiental.org/ (retrieved June 29, 2015).

37 According to Veracel, there were some 15,000 Indigenous persons and 17 villages within the area where the company operated -14 Pataxó and three Tupinamba aldeias. http:// testemu.insix.com.br/en/relationship-with-the-community/indiancommunity/ (retrieved June 2, 2015). 
ing as much as 52,000 ha. Unlike in Espírito Santo, the number of the Pataxó villages has steadily grown, since new, smaller villages have sprouted, so that currently there are 36 aldeias $^{38}$. In both cases, as the geographical maps show, like in other parts of Brazil and Latin America, there are overlapping and contested interests of various actors. (Map 7 and 8.)

38 http://pib.socioambiental.org/pt/povo/pataxo/2303 (retrieved June 2, 2015). 


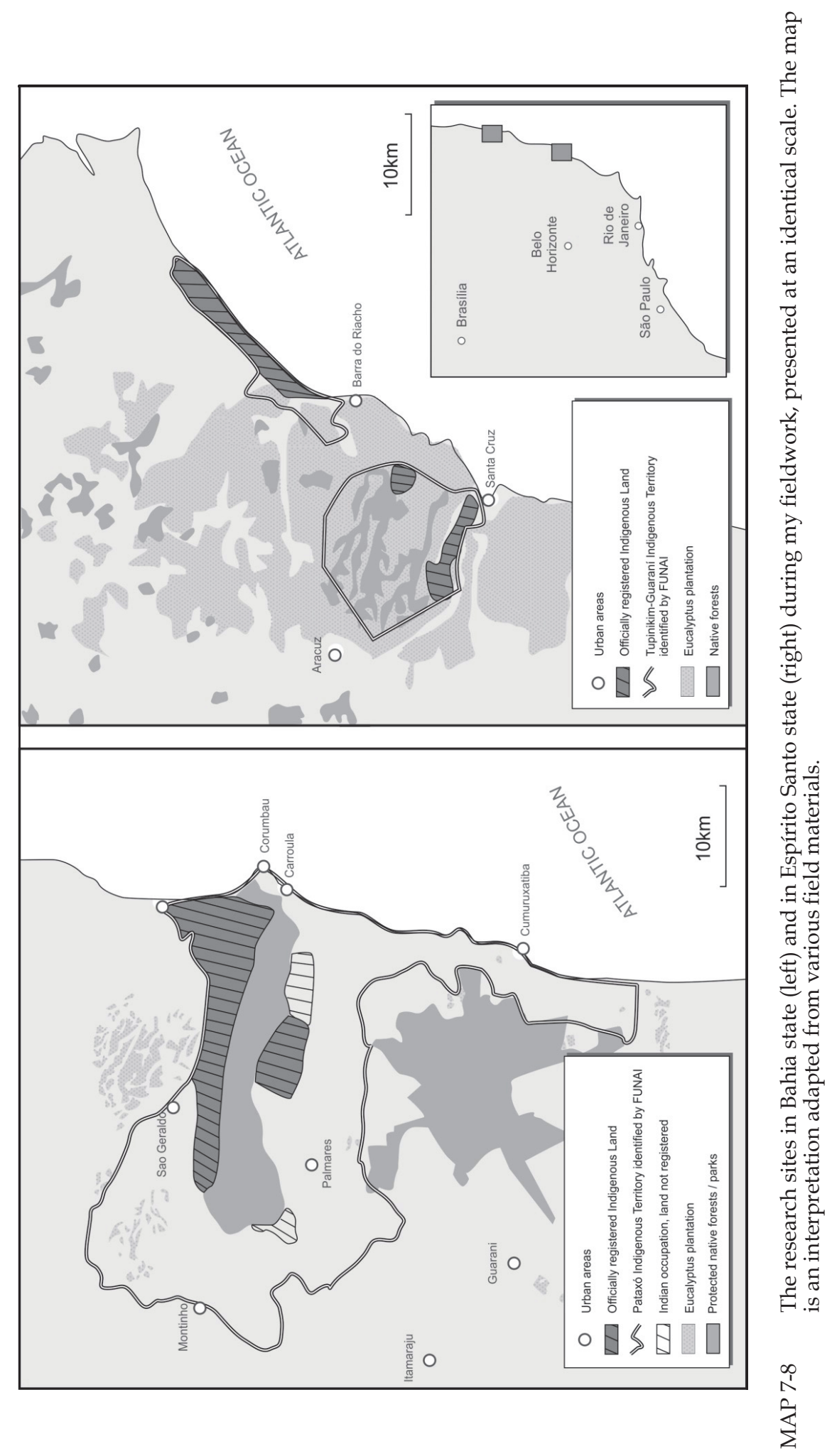


The personal and group interviews were made among the Indigenous leaders of the villages - the caciques of the Tupinikim, the Guaraní, and the Pataxó, and the (elder) shaman leaders of the Guaraní. There were also a few conversations with the other community members, such as teachers and youth. The interviews were carried out in homes, schools, and public spaces, where I also made personal observations. In 2004 and 2006, the main research focus was on the Tupinikim and the Guaraní land struggle, and in 2011 (and also to a lesser extent in 2006) on the Pataxó case. The total time for these three fieldwork phases was two months, including meetings with the researchers, public authorities, and NGOs. I interviewed 30 Indigenous persons in Espírito Santo and Bahia states (six Guarani, nine Tupinikim, and 15 Pataxo); some I interviewed two or three times to learn of any changes that had taken place since the last session. Hence my study has some longitudinal perspective on the land struggles and the conditions of the communities that are discussed in the articles of the dissertation. My aim was to select villages representing a wide range of positions towards the companies and their plantations. The names of the persons or villages are usually not provided in this research, except in a few cases where the leaders were interested in being visible or represented ("because I don't care and the company already knows me," or "we need attention from Europe"). Although the number of interviewees is relatively low, certain CCR issues started to re-emerge, so I made the decision on the saturation of research data. Concerning further research, it would be relevant to make more interviews of other community members to enrich the research material. Focusing merely on the political leaders, caciques $^{39}$ - most of whom were men - must also result in some limitations for the data. However, since the objective was to focus on land struggles and relations with the companies, the leaders were selected as a primary target group.

The visual research material consists of photographs, "documentary snapshots," rather than images taken with a careful consideration of the photo setting. Visual presentation of the Indigenous Peoples has always played a significant part of research, both South and North (see, e.g. Pyykkönen, 2007). It was not difficult to get permission to photograph, but I sometimes felt I was intruding on a person's privacy. Furthermore, as some of the men hurried to put on their tribal outfits, including the face painting that indicated, for example, marital status, I felt a bit like I was seeing them with the gaze of a Western tourist. Nevertheless, it was the way they wanted to be photographed, so I did not want to interfere. Furthermore, a lengthy interview session can create space for trust, and hence the interviewee her/himself can suggest a photo to be taken - often with the tribal outfit. The caciques liked to be portrayed with their feather headdress, indicating high status. Although I amassed a relatively large photo collection, I have considered certain issues carefully before publishing these images, especially those of youth and children: what the context is, i.e., how they are

39 The leaders are powerful members in communities. The term cacique has a colonial origin (Ciccarone, 2006, personal communication.) 
presented, and to what extent they are recognizable. As photography became a more integral part of my life, I developed a more critical eye.

"Ethnomapping" is used in the participatory management of natural forests, or sustainable tourism (e.g., in the Amazon). In my study, ethnomapping constitutes an additional, minor research material to support interviews, and villagers of various ages participated in it: by asking the people to draw their village, I organized an ethnomapping session among the Guaraní, whose houses were surrounded by natural forests and swamps. Some may criticize the whole mapping idea as a Western construction that is unsuitable for Indigenous studies. However, I was curious to see how (if at all) the Guaraní perceived eucalyptus plantations that were located further away (compared to the Tupinikim, who were in a totally different situation). Ethnomapping may also have some ethical problems if its aim is to present people's livelihoods. Like in any research on this topic, we are dealing with a very personal, sensitive sphere of life, especially when natural resources are controlled by environmental authorities. As is common in fieldwork, at times I was given contradictory stories (among the Pataxó); one source said that village members do not practice hunting, yet another source referred indirectly to hunting methods. The Guaraní categorized their hunting principles according to their cosmology. What was also interesting-compared to the socio-environmental conflict maps presented earlier - is that these personal Guaraní ethnomaps illustrated the overlapping and neighboring functions in the area: the villages, natural forests with biodiversity, public roads, Aracruz plantations, and the gas pipe of Petrobras. It would also have been interesting to organize a collective mapping session and to follow the social dynamics it involved between the villagers. In addition, ethnomapping in Bahia would also be relevant to indicate how the Pataxó perceive their territory and its borders, and which functions and interests are in conflict or overlapping.

Entering the field usually began with discussions with the Brazilian academics, such as anthropologists, geographers, and social scientists from the Federal University of Espírito Santo (UFES) and the Federal University of Bahia (UFBA). My Brazilian research partner institution was the Research Program on the Indigenous Peoples in Northeast Brazil (Programa de Pesquisas sobre Povos Indígenas do Nordeste Brasileiro, PINEB ${ }^{40}$ ), which is part of the Department of Anthropology and Ethnology, UFBA. The extant research (referred in my articles) focused mostly on anthropological and ethnological approaches on the livelihoods, cultures, and identities of the communities, or the management aspects of the companies. One day in 2006, I visited the Tupinikim and the Guaraní with two anthropologists. Celeste Ciccarone (UFES) had studied the Guaraní leadership, which was often based on elderly female shamans. According to the anthropologist Sandro José da Silva, who researched the Tupinikim identity, there were tensions between the two tribes: while the Guaraní had an imaginary of a sacred land, the Tupinikim supported the market economy and participated in

40 http://www.pineb.ffch.ufba.br/(retrieved August 1, 2015). 
the Fibria/Aracruz social forestry program. Monitoring the Brazilian and international research background was important for obvious reasons, in order to get access to all possible data related to the areas and actors, and also to avoid topics that overlapped too much. But after presenting my research design at the universities, I soon realized that despite the seriousness of this societal issue, there were no crowds of academics studying it. This impression was particularly confirmed when I inquired in the Pataxó villages; aside from supporting civil society groups, only some foreign journalists had visited them. Thus there were very few studies available on the CCR issues, and most were literature analyses. Since the Indian villages were closed to outsiders (except the villages with tourism), Professor Maria Rosário Carvalho (PINEB), a well-known anthropologist in the villages, wrote me a recommendation letter to show to the caciques in order to facilitate conducting interviews in the villages. In addition to the universities, the Brazilian civil society organizations were most helpful, especially by offering vital background information and literature: SOS Mata Atlântica Foundation in São Paulo, Cepedes and Flora Brasil in Bahia, and FASE and the Movement of Landless Rural Workers in Espírito Santo.

I would describe my intensity with the research field in terms of "vertical" and "horizontal" engagement: it was vertically a relatively long-term process, where I could observe changes taking place in the CCR relations as a dynamic formation of the land struggles. If I had had a possibility to return to Espírito Santo as well in 2011, the longitudinal picture would have been more complete. However, I made up for this by discussing with Dr. José Augusto Sampaio (UFBA) the situation in the area and his research team's final report, introduced in my third research article. In regard to the horizontal engagement, i.e., the intensity of contacts with the communities, I would consider my participation narrow or limited. I did not live with the communities and experience their everyday life practices, as some anthropologists do to get a deeper understanding of people's life worlds. On the contrary, I felt that I did not want to disturb people and their daily activities too much, especially when there was no guarantee that my research could benefit them. In addition, I got the impression-and the interpreter agreed - that the Pataxó in particular seemed uncomfortable about voicing their opinions of the companies, even though we stressed that my research was not connected either to the companies or to the government or NGOs. The Pataxó also appeared to be afraid of losing the small benefits from Veracel's corporate philanthropy. All of this made me consider the consequences of publishing my research results containing confidential data. However, my playing the "Finland card" (i.e., the presence in the region of companies from my home country) made people more interested in participating in the interviews. Hence this common denominator, a link between the researcher and the respondent, enhanced the research process. It was actually this link between two nations that I often (though not always) used when introducing my research: I also wanted to find out if they knew anything at all about the Finns. To justify my visits, in the case of the Tupinikim and the Guaraní, I brought paper copies of 
articles I had managed to publish in the mainstream press ${ }^{41}$. The interpreter translated the contents of these into Portuguese for the leaders and other community members. At that point, some of the people who had been photographed also saw their pictures in the articles. (Image 6.)

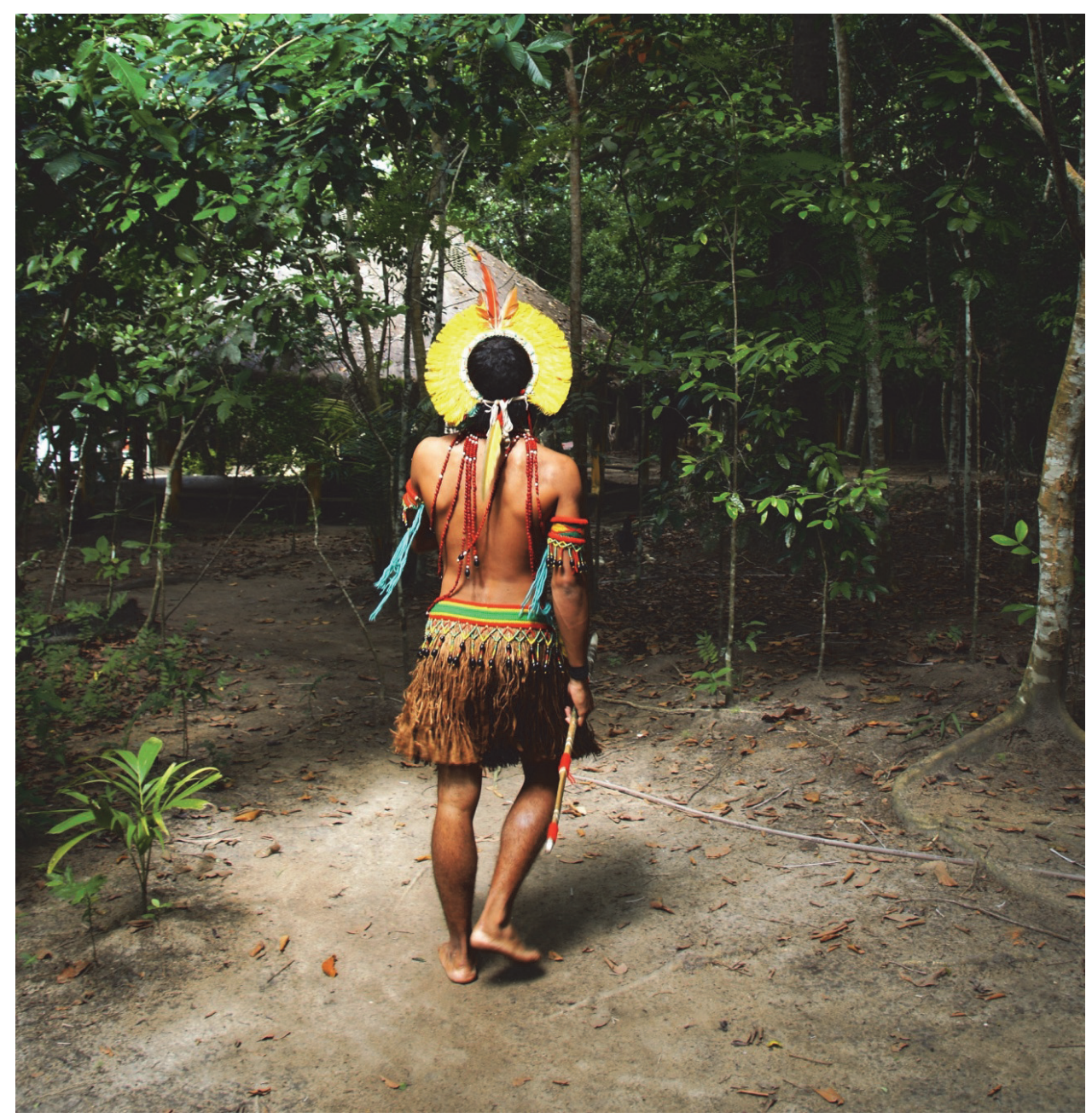

IMAGE 6 A young Pataxó introducing the aldeia (Photo: Susanna Myllylä).

All three Indian groups spoke Portuguese, and only the Guaraní had managed to sustain their traditional Tupí language skills. Since I speak Portuguese at only an intermediate level (though I read and listen well), I relied on three interpreters during interviews and other discussions - a student in geography, a non-academic Brazilian (with Finnish roots), and an NGO consultant (whom I used only twice). In some cases, specific Guaraní terms - for instance, those describing elements in nature or cosmology - required further explanations. I also

41 S. Myllylä, “Halpa sellu käy intiaaneille kalliiksi”, Helsingin Sanomat, March 13, 2005. 
attempted to understand the cultural backgrounds of the Indigenous groups by studying them beforehand. Using interpreters in different cultural contexts is an art in itself, especially in "developing nations" contexts (see, e.g., Devereux and Hoddinott, 1992), so I will point out just a few issues here. First, one has to accept that the information is more or less filtered through the interpreter. Yet I was able to follow and, to some extent, guide most of the conversations and to intervene when necessary. For instance, there were situations in which the interpreter did not allow sufficient breaks, or omitted some details, probably because she/he thought them less relevant. The involvement of local interpreters was useful overall, because they had insights on the society and on the Indians (especially on relations with the wider society), and if I was going to present a question too directly, they suggested another expression (finding a proper way to present questions was an issue we often planned together beforehand). I also wondered about my identity; whether I would be perceived as neutral when I was in the company of the third interpreter, the NGO consultant. When we planned a visit to the Pataxó villages, he said we could go only to those aldeias that collaborated with "his" NGO. Hence there were invisible borders, "NGO territories," as the organizations had "marked" certain Indian villages. Then I understood that the situation was not so harmonious from the side of the NGOs either. I concluded that despite the insightful information NGOs possess, I would prefer to travel with an interpreter without strong attachments, such as a student, researcher or professional interpreter. Nevertheless, a Western person is always an outsider to whom labels are attached. In previous experiences in the South, I found that a researcher, if not considered a tourist, can be taken for a NGO representative (and thus be asked for assistance), or a government "agent," a corporate consultant, or a land investor (and, in all the latter cases, thus be received aggressively or with suspicion). In Brazil I did not receive any direct references to either of the previous roles.

Furthermore, my interpreters often remarked on some nonverbal expressions that contrasted with the respondent's comment, so this helped me to pose further questions. Thus the two interpreters' role more closely resembled that of a research assistant, since I encouraged them to freely present their insights into the situations. In addition, the interpreters also helped in the logistics and in organizing meetings, which was often laborious. For instance, after numerous telephone calls, we got a representative of FUNAI to agree to an interview in Porto Seguro, but he never appeared at the meeting place, and we never heard from him again.

Concerning data gathering in interviews, I initially recorded discussions with a minidisc recorder. But just in case, I also wrote key points in my notebook. The advantage of the recorder was that it enabled me to collect considerable detail, which then allowed me to concentrate on the situation in the moment. When I asked people to tell about their personal history, I just let the device record with a minimum of questions and breaks; from these one could actually get the richest data. After the recordings were transcribed into Portuguese (and some of them were translated to Finnish), I could compare the mate- 
rial to my written notes and trace some interesting points that were not translated or otherwise noticed in the conversation. On the other hand, the whole process was time-consuming, as well as expensive. Also, people became more self-conscious when I picked up the recorder, and they did not seem to speak as openly. When the conversations went on for hours, taking notes by hand became quite arduous; later on at the hotel I used to continue the work and typed the notes into the computer, adding preliminary analyses. To save time in the field, I eventually decided to use a portable computer or tablet in the interview sessions, where I took breaks in between different interview topics. I wanted to proceed at a slower pace in order to ensure the accuracy of the information I received. However, for fieldwork "in the South," a traditional notebook is still a very valuable tool for data-gathering, since a) it enables the researcher to mindmap or otherwise jot down ideas and further questions during the interview; $b$ ) it is not always safe to carry computers (or other technical equipment) around, and in many instances, c) the interviews occur in spaces where there is no possibility to sit down or use a table.

Due to the viewpoint taken, research material on corporations plays a lesser role in this study. There were a few personal communications with company representatives, such as interviews and emails. In 2006 I asked for an audience from Veracel by email, but the meeting did not proceed because our schedules did not match. In 2004 I asked to visit Fibria/Aracruz, with the assistance of the local environmental consultant, but it did not succeed since we did not find the right person. The land struggle had already reached its peak due to previous violent corporate actions towards the Indians and a forthcoming Indigenous protest. Thus like the local anthropologists, some of whom stated that "in the situation where the trust is gone in communication," I did not see much sense in carrying out an interview. Moreover, the environmental consultant told me that "most likely they would just put the promotional video on, like they usually do when someone visits their office". At a 2011 appointment at Stora Enso, I expected to meet the new head of global responsibility, but instead I was received by two young managers. The meeting made me ponder the consequences of the rather frequent changes in management personnel of the business units dealing with stakeholder relations, since it seemed to be a quite common phenomenon both in Finland and Brazil. Concurrently, there is a chronic leakage in institutional memories. For instance, the managers I met told me they were not familiar with the land tenure questions, not to mention the history of human rights violations by Fibria/Aracruz as Stora Enso's partner company. The loss of institutional memory must also have some influence on policies and strategies when tackling the company's long-term relationships with local communities and their claims. In any case, the situation gave Stora Enso's business partner in Brazil quite a free hand. Since I was still processing my research data, I presented only a few findings for discussion. Later on (in the Discussion and Conclusions chapter), Stora Enso gave its response to some of my research results. The rest of the company material includes corporate reports, public 
statements and campaigns, and other available information, especially from the Internet. Stora Enso Global Communications Group helpfully allowed me to use their photographs in this dissertation.

Finally, as described in the previous chapter, my research strategy consisted of interviews among a large variety of diverse actors within a multi-sited framework (see Marcus, 1995) on the Atlantic Forest domain. The earliest field research, in 2004, lasted two months. Despite the challenges in reaching people in various positions, the total number of respondents from all four fieldwork periods is 135. Some of the interviewees are listed in the literature section at the end of this dissertation, however, since this study includes a sensitive data, I wanted to keep many respondents as anonymous.

In addition, local researchers advised me to be cautious, since fieldwork in the region was not without security risks. Traveling by road is probably the most serious of these, given the reckless driving culture, poor roads, heavy rains, and floods that cause landslides. When rain blocked some roads and made travel otherwise risky, it caused the loss of valuable working days and scheduled meetings. Moreover, Brazil has the world's highest level of criminality and violence. The risky situation already commences on arrival at the Rio de Janeiro airport, when the taxi driver locks the doors of a car with tinted windows and rushes to the hotel or bus station. The reason for this is the favelas between the airport and the city; someone planning an attack can wait for a foreigner or a group of tourists at the airport and inform an accomplice at a favela farther down the road. In some cases thieves have placed large rocks in the road, forcing tourist buses to stop so the passengers could be mugged. In 2006, a couple of hours after I had left Rio on a bus heading north, a road accident occurred on a Rio-Niterói bridge I had just passed, and the traffic was completely jammed. Then thieves suddenly appeared and robbed the people stuck in their cars and buses; the criminals fled as quickly as they had appeared. If an emergency occurs on a Brazilian highway, people are afraid to help, as they fear being set up for a robbery. Furthermore, fake or corrupt police who illegally demand "tolls" may pose a dilemma: to stop or not to stop. Traveling at night, even by bus, should be avoided. However, since the country's distances are so huge, and the bus timetables cannot always be coordinated, it was necessary to use night buses in the course of my research. It was rather common to see a car accident, or a truck flipped over on the road. Wandering cattle often created dangerous situations. One night I was jolted awake as the bus lurched from side to side while going fast, and it appeared we had hit a mule.

Since the narrow Brazilian roads are also busy at night, especially with fully loaded trucks, we were lucky that the bus driver was able to keep the vehicle in the right-hand lane. Traveling by road and through bus stations at night, I was constantly concerned with how best to protect and hide the research data in my clothing, particularly when there was no possibility to use the Internet (at that time, options such as cloud services were not available to save the digital photographs, which took up considerable data space). Thus not only was the collected research data critical for my work, but it also contained confidential 
material concerning people's lives, not to mention their opinions of the corporations. (Image 7.)

Furthermore, when traveling by rented car or taxi, one must ensure that the vehicle is reliable and can drive on rough roads, and that the tank is full, especially when going to remote regions. Yet often things do not go as planned; one needs to be constantly alert and anticipate all kinds of possible situations.

In 2011 I had based myself in Porto Seguro, Bahia, and was planning to continue interviews in a distant Pataxó village with an interpreter's help. A few days before, I had arranged for a local young man from the city (a "half-Pataxó," as he described himself) in his twenties to be our driver. We departed in the early morning, and after passing the last fuel station in a small town, we entered a wide landscape of cattle ranches, deforested areas, huge eucalyptus plantations, fruit fields, and small natural forests. With very few road signs, it was quite challenging to find the way to the aldeia. We drove slowly on rocky and damaged roads, which sometimes ended suddenly in a thick eucalyptus plantation, or brush. Halfway there, the car's motor started to give out, which made me worry about possibly having to spend the night by the road. There was a shorter route, but due to a damaged bridge, we had to approach the village from another direction, which was partly blocked by eucalyptus. (I wondered how the villagers themselves coped, especially in emergencies. Later, during the interview, I heard that some of the villagers' difficulties were actually due to the scarcity of vehicles, and broken roads.) However, an incident took place before our journey: just minutes before going further into the desolate area, I was shocked to notice that our fuel was already nearly gone, even though the tank had been full when we rented the car the previous evening. It turned out that the driver had gone cruising with his friends to the neighboring cities for the whole night. So we turned around to look for a fuel station, refilled the tank, and started our all-day journey. Since the young man was the relative of a local researcher who recommended him, I trusted him when he promised to take the car to his house rather than a public parking area. The situation was a good lesson for all of us, and perhaps most for the inexperienced young person, who did not have previous work experience, and who regretted being thoughtless. However, the incident was worthwhile for the interesting discussions we had with him.

Doing research in an environment where violence related to the research topic occurs regularly was a cause for concern. I must admit that compared to my previous field experiences in Africa, in Brazil I felt a bit uncomfortable when traveling to and staying in the research sites. Although the Indian Statute of 1973 forbids leasing land contracts to non-Indians, the governors in Bahia (1976-1980) illegally distributed land titles to the ranchers. Like the armed security agencies contracted by some pulp companies and other agribusiness actors in Bahia, the ranchers have continued to kill Indigenous people as well as AfroBrazilian Quilombos, while the police have evicted and imprisoned the Tupinambá people, keeping them from their ancestral lands. ${ }^{42}$

42 http://www.survivalinternational.org/news/6090; http://lab.org.uk/brazil-upsurgein-rural-violence; http://www.culturalsurvival.org/ourpublications/csq/article/thepataxo-bahia-persecution-and-discrimination-continue (retrieved August 1, 2015). 


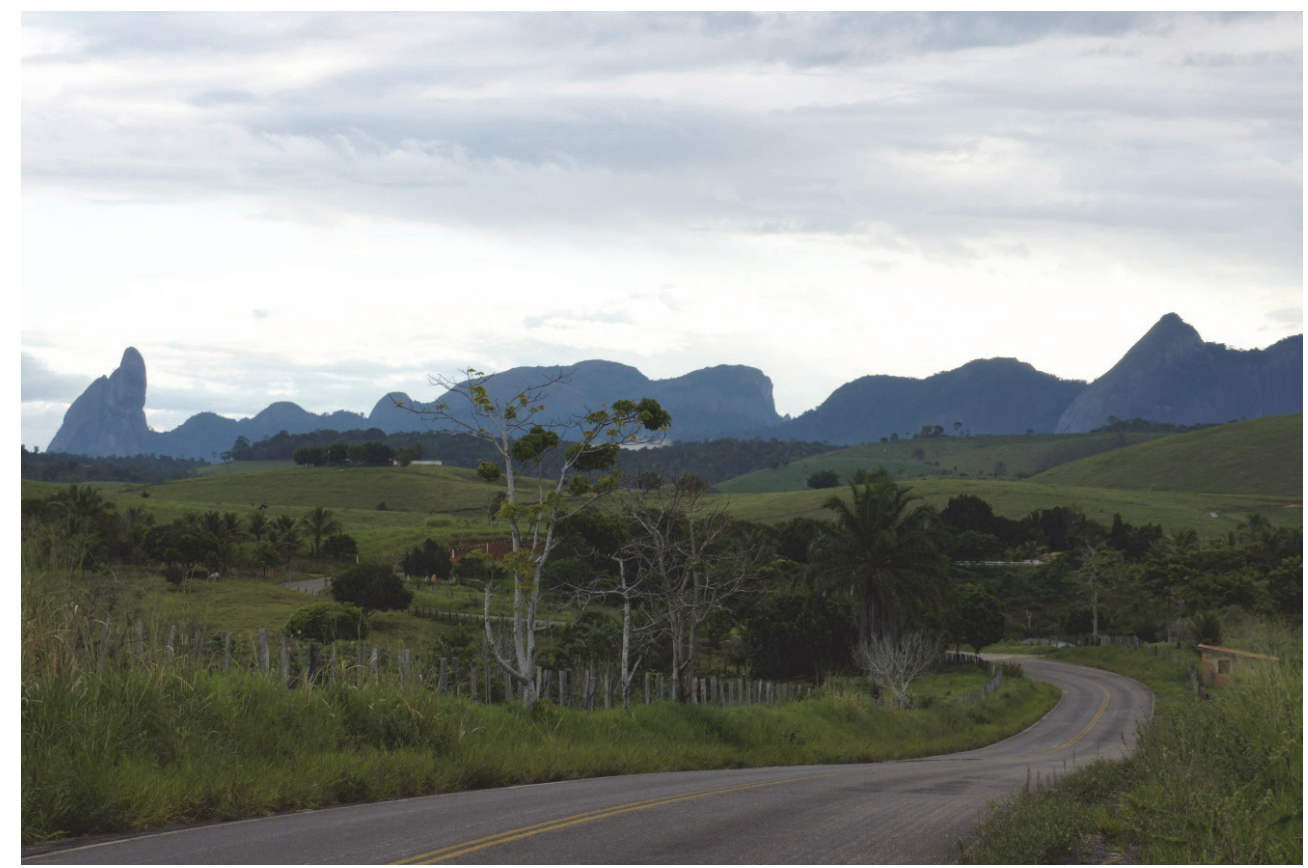

IMAGE 7 Landscape in Bahia (Photo: Susanna Myllylä). 


\section{THE RESEARCH ARTICLES AND THE MAIN FINDINGS}

The whole research process has basically been divided into two phases. First, the land struggles were deconstructed and their elements analyzed, as elaborated in all three research articles of the dissertation. Second, since both case studies were examples of asymmetrical corporate community relations, and there was a scarcity of analytical CCR tools in the extant literature, I considered it relevant to generate a theoretical framework for interpreting, assessing, and balancing the CCR situations. The result of this endeavor is presented in the third article. Next, the findings of the research articles are briefly introduced, with a summary of the main results.

\subsection{The rising collective and individual agency of the impacted communities}

Myllylä, S., 2010, "Ethnoterritoriality Confronting Multinationals: Indigenous Peoples' Perceptions on Eucalyptus Plantation Industries in Atlantic Coastal Brazil," Arctic \& Antarctic: International Journal of Circumpolar Sociocultural Issues, Vol. 4, No. 4, 97-145.

In the first article the focus is on the complex relationships between the Indigenous communities and the multinational corporations, especially scrutinizing: i) the changes the companies have caused in their livelihoods and cultures, and ii) the land dispute power struggles and the tactics of both actor groups. I look at the situations of three Indigenous groups: the Tupinikim, their allies the Guaraní, and the Pataxó. All of them share a common background concerning their territorial claims and experiences in the pulp production industry vis-à-vis the multinationals Fibria/Aracruz and Stora Enso and their joint company, Veracel. 
I have discerned various local situations in which the three Indigenous groups encounter global corporations in the form of land conflicts.

According to my fieldwork findings, eucalyptus plantations have had a multitude of negative impacts on the Tupinikim and Guaraní communities. These include a) cultural (weakening of community cohesion, language skills, and traditional customs), b) livelihood (unemployment, loss of subsistence agriculture), c) social (drug abuse, new diseases), and d) environmental (loss of natural forests, drying of land, loss of animal species, water pollution). They affect the Tupinikim in particular but also the more isolated Guaraní. Moreover, the Pataxó pointed out a number of negative social and environmental impacts following Veracel's arrival that were quite similar to those experienced by the Tupinikim and the Guaraní.

In these specific cases, the land struggles are inherently related to the communities' primary livelihood, the Atlantic Forest. The companies used tactics indicating that their adversary did not represent "pure Indians" originating from the place in question. I have scrutinized the pulp corporations' diverse tactics, from social programs to violent confrontations, and the devaluation of Indigenous identities in ways that seem imperialistic. Many of these tactics have been aimed at obtaining societal acceptance for corporate interests. Social programs by MNCs often serve as cases of governance and guided inclusion targeted at indigenous communities. The three Indian tribes, in turn, have defended their territories by collective action, such as New Social Movements, and via their own tactics, such as protests and land occupations, in order to achieve publicity and societal acceptance. When comparing the rhetoric and actions of the different parties in the land conflict situations, I found a great discrepancy between the global company and the Indigenous community in terms of how the reality and "justice" were perceived. Modern corporations using technological advances usually fail to recognize this, especially in regard to ecologically related issues.

In addition, the Tupinikim experienced a severe collective trauma in 1967 due to Fibria's / Aracruz's initial violent invasion of the area, which has been replicated through violent incidents by the company in recent decades. This phenomenon of traumatized communities - the feeling of losing control over one's life in the face of collective disaster-has been observed among various Indigenous communities that have lost their livelihoods, often due to an external factor. In the land conflicts with the MNCs, the Indigenous Peoples' territories, livelihoods, and identities are mutually recreated via the processes of ethnogenesis. I also introduce the concept of ethnoterritoriality, in which the land struggles against MNCs have profoundly affected the identities, social cohesion, and worldviews of the Indigenous communities. 


\title{
3.2 The subaltern communities resisting organizational hegemony
}

\author{
Myllylä, S., E Takala, T., 2011, "Leaking Legitimacies: The Finnish Forest Sector's \\ Entanglement in the Land Conflicts of Atlantic Coastal Brazil," Social Responsibility \\ Journal, Vol. 7, No. 1, 42-60. (The main author was Susanna Myllylä.)
}

The aim of this second article is to examine the legitimacy problems faced by the Finnish forest industry in the Brazilian context, specifically from the perspective of the region's three Indigenous communities: the Tupinikim, the Guaraní, and the Pataxó. The article scrutinizes the corporate tactics in gaining societal legitimacy, both in Brazil and in Finland; these were categorized into thematic groups. On the other hand, the Indigenous Peoples' resistance movements, tactics, and rhetoric when searching for legitimacy for their land claims were analyzed. Drawing from the Brazilian case study, the aim was also to pinpoint some theoretical gaps in CSR theory in regard to the global South.

The study indicates that the legitimacy of the Finnish companies is compromised by the unethical tactics of their Brazilian business partner, Fibria/Aracruz. The search for legitimacy requires the company to change its corporate knowledge production systems. It also requires the company to be open to different types of knowledge that are locally attached. The study offers new information about the relationship between multinational corporations and local communities in Brazil, especially from the perspective of Indigenous communities. In terms of social justice, the land rights of Indigenous Peoples are at the core of corporate ethics in its fullest sense. Brazil's Indians belong to the poorest and most ostracized strata of the population. Often lacking official land rights, they are the ones most affected by, and vulnerable to, large-scale pulp industries. Hence it is argued that large corporations have an even higher ethical responsibility in the societies of the global South.

The case studies exemplify the complicated situations Finnish firms have been involved in when doing business in the global South. Given that these firms were entering a new cultural environment, we made several conclusions. First of all, Brazil constitutes a societally complex "risk" target country for foreign investments, due to numerous local disputes over land resources. An MNC is a powerful political and economic actor, critically influencing regional development processes and land policies: the Finnish forest industry cluster (and the attached institutions, such as export credit agencies) has a clear and mainly negative role in this constantly expanding development model. Furthermore, the Brazilian discourse on the development impacts of pulp production has remained unknown in the North. In Finland it is difficult for the wider public to get (objective) information on the local and national situations. The Indigenous communities - like other "traditional communities" and landless rural peasants-are excluded from decision-making processes concerning the arrival and location of foreign companies. There are also severe weaknesses in environmen- 
tal impact assessment procedures, as well as in social impact assessments. However, the Indigenous communities are rather well organized, and they use various national and international networks to protect their rights - as a whole, the communities constitute a wide civil society action group that cannot be ignored. The pulp and paper corporations may employ various tactics to give their interests legitimacy, varying from social programs to violent confrontations and malevolent attempts to deconstruct the identities of Indigenous communities. Stora Enso and other Finnish companies have been passive in the face of their Brazilian partner's human rights violations. Corporate responsibility is mainly concerned with the skilled company employees, while the Indigenous groups do not have any economic importance as stakeholders. The voluntary nature of CSR and the related "hypocritical corporate ethics" are highly problematic: although the companies have outlined their social responsibility principles and policies, the situation is rather different in practice. In all, the legitimacy of the Finnish companies in Brazil is compromised by the i) unethical tactics of their Brazilian business partner, and ii) how the Finns have responded or failed to respond to Fibria's/Aracruz's actions.

This article is mainly based on my empirical research, while Professor Takala has contributed to the legitimacy discussion of the study.

\subsection{CSR reclaimed by the Indians}

Myllylä, S., 2014, "A Concentric CSR Roadmap Model for Host Community Relations in the Global South," EJBO-Electronic Journal of Business Ethics and Organization Studies, Vol. 19, No. 1, 27-51. ${ }^{43}$

The purpose of this third article was to find new, grassroots-based CSR approaches for corporate community relationships in the global South and hence to achieve some distance from the Northern ethos. In the Southern Hemisphere, companies face considerable challenges in identifying and managing the stakeholder arena and the heterogeneity within it. The article critically analyzes the term "stakeholder" and concludes that it has a corporate "top-down" or even Eurocentric ethos that has been challenged by the grassroots movements.

First, Veracel's production impacts on the Pataxós were examined. Second, Veracel's CSR policy and its subsequent impact were brought under closer scrutiny by juxtaposing corporate words with corporate actions. Third, the local community's own CSR expectations were presented: what constitutes responsible business practice, and what does a good relationship entail according to the Pataxó? Fourth, it was argued that bridges need to be built between business ethics and development studies. In addition, a number of research gaps were identified in the extant literature, which this paper attempts to fill.

43 http:/ / urn.fi/URN:NBN:fi:jyu-201404101501 
I concluded that firms can be considered responsible not only for their production impact but also for the CSR performance per se: philanthropic activities may have diverse and even counterproductive influence on local communities, in terms of ownership, equality, sustainability, and transparency. The lopsided business production impacts and corporate CSR activities can divide local communities - even at the micro- or family level-since people possess diverse interests and expectations vis-à-vis the company. In order to reduce local resistance, companies tend to increase philanthropic assistance, but without solving the underlying problems that spark social unrest and resistance to the company. The article stresses that if the most critical questions, such as land titles, are not resolved, companies appear simply to be buying local acceptability. Thus philanthropy runs a considerable risk of amounting to corporate social irresponsibility in the global South.

Furthermore, voluntary social projects among the local communities are rarely evaluated by independent parties; instead, the corporations police themselves. In addition, it appears that MNCs take on, and are expected to take on, various roles of the public sector. Thus firms have increasingly become gapfillers for the public sector in nations that struggle with governance crises or otherwise allocate too few resources to the sector. The gap-filler situation also creates dependency on corporations and allows local governments to continue to evade their responsibilities. The end result may be that CSR supports bad governance structures. In all, I allege that the CSR field and its practices constitute a vast gray, "informal" sector in Southern societies that deserves a much closer look.

One goal of this research has been to assess to what extent corporate words matched corporate actions concerning the CSR initiatives and the stakeholder relationships. There were signs that the companies were interested in improving their stakeholder relations. Nevertheless, the CSR actions and stakeholder relationships were portrayed as more active and trouble-free than they actually were. Overall, the reports exposed a tendency to either prettify or keep silent about the situations, so the presented facts were selective.

To summarize the research findings, my aim was to generate a CSR framework that reflects societal circumstances common to the emerging and developing economies, and consequently, to present relevant CSR principles. The purpose of the model was to deconstruct the ambiguous CSR concept and to help bridge the disciplines of business ethics and development studies, both theoretically and methodologically, by including the values of ordinary people. The "Concentric CSR Roadmap Model" outlines 22 principles, and 49 subprinciples, organized in three hierarchic CSR levels: binding, ethical, and philanthropic responsibilities. The model states that philanthropy should not be used as a CSR strategy when initially approaching local stakeholders. Firms should not have direct access to the "core" of the communities, that is, to their internal dynamics, culture, and development. Instead, judicial and other binding issues ought to be tackled first. In addition, the model indicates how to plan and execute philanthropic activities so that ethical aspects are also considered. And as the corporations start to operate as gap-fillers, this requires more fun- 
damental public-private debates, and clarification of roles and responsibilities. The model also calls for new "bottom-up" approaches and fieldwork in data collection in business ethics research concerning the global South (see Appendix).

Veracel's case epitomizes a business-as-usual approach, where the company has simultaneously operated in all three CSR levels, and in a very perfunctory manner. Before binding issues were tackled, the company started to offer modest financial and material support to certain Pataxó villages. The company has not been active in solving land-dispute cases in Indigenous territory. Veracel's stakeholder approach has targeted the host community in a biased, divisive manner, leading to social disintegration. Overall assistance to the Pataxó communities was minimal compared to the huge financial profits that Veracel produced in the region. The stakeholders were not involved in the business decision-making on the more equitable benefits, but they did not claim to be, except concerning the land issue. On the contrary, the Pataxó were afraid to lose even the small benefits. Veracel has violated many of the Indigenous Peoples' rights recognized in the Brazilian constitution and international conventions.

\subsection{Results summary}

In light of my research, a socio-environmental conflict sparked by pulp and paper companies can be formulated as follows, by adapting elements from Mitra's (2011) framework of the culture-centered approach:

The influence of pulp production, the unheard land claims, and asymmetrical physical and rhetorical confrontations comprise a pervasive life experience of the affected, in which the agency of the subaltern group is been established in the forms of both collective and individual resistance towards the organizational hegemony, and reclaiming of corporate social responsibility. The land struggle has both converged and divided the communities, in which the dynamic processes of ethnoterritoriality and ethnogenesis recreate Indigenous identities.

Hence these new Indigenous identities can be seen as hybrid formations between intertwined modern land struggles and traditional elements such as the perceptions of ancestral land.

The land struggles have been inherently related to the degradation of the Atlantic Forest, whose regeneration has been largely hindered due to the physical barriers created by the eucalyptus plantations. Although Veracel has established a nature reserve (as it was required to do), scientific research indicates that the conservation of the Atlantic Forest remnants and their connection would require larger land spaces. A correlation exists between the natural forests and the Indians: as the forests diminish, the environmental authorities exert more control over the livelihood practices of the Indians. This is in contrast with 
the constitutional rights of the Indians to use all the natural resources within their Indigenous Territories.

The territorial claims by the Indians have appeared quite differently. While the Tupinikim and the Guaraní increased pressure on Fibria/Aracruz to give up the whole Indigenous Territory, the movement of the Pataxó seems to have been less consistent and targets only certain parts of the Indian lands rather than the entire Indigenous Territory. The dispersion of the movement may be caused by Veracel's corporate philanthropy, which calms the critical local voices. It seems that whenever an Indigenous protest takes place, the company ombudsman rushes to organize a meeting with (some of) the caciques, and they are offered more philanthropic assets. Simultaneously, the Indians become more dependent on company-provided services that the municipality should be providing. The situation poses a conundrum for the Indians: since education is vital to their youth, it is also understandable that they are reluctant to criticize the company and thus risk losing the asset.

During the fieldwork I found that one could reasonably consider the firms responsible not only for the influence of their production on the Indigenous communities but also for the CCR performance per se, since philanthropic activities may treat the local communities unequally. Corporate philanthropy may entail questionable objectives, such as the "guided inclusion" of local communities. For instance, social programs have divided the Indian villages socioeconomically both in Espírito Santo and Bahia, causing some fractures in Indigenous resistance movements. In Espírito Santo, the participation of the Tupinikim in the company's social forestry program caused tensions with the Guaraní, who rely on their cosmology of the sacred land. In Bahia, Veracel's presence and selective philanthropy has divided the villages, even at the family and individual level. Like the Guaraní generally, some Pataxó villages prefer to not to have any contact with the pulp companies. I would argue that although Veracel is collaborating in social programs with the municipalities and other actors in the region, the lopsided situation is due to the absence of an independent body, or an effective government or Indigenous organization, to assess and govern what is actually going on in corporate philanthropy. The overall ambiguous "Wild West" situation among the Indians that is created by corporate philanthropy also opens up the supporting NGOs and their uncoordinated activities to criticism.

Throughout the field research the CCR was redefined implicitly and explicitly by the three Indigenous communities, while during the last fieldwork phase I focused on collecting various redefinitions of CCR by the Pataxó. Diverse views on the responsibility issue emerged among them, which may also reflect their Indigenous movement situation. My Indigenous respondents defined a responsible firm either as one that served as a gap-filler for the absent public services, or, conversely, as one that avoided any contact with the Indigenous Peoples. A view all respondents shared was that before all else, Veracel and its owners should respect the Indigenous Territory, withdraw immediately (prior to the official registration), and pay compensation for the environmental 
and economic impacts it has caused. This unanimous opinion among the villagers also indicates that there is potential for a coherent Indigenous movement, although it is not fully activated, for reasons referred to above.

In regard to the Finnish companies' involvement in pulp production in the region, they entered rapidly expanding but relatively risky business spaces when they located to Brazil. I cannot help but draw an analogy with the Portuguese colonizers who regarded Brazil romantically as a "new continent" with endless land resources to be exploited. This perception or discourse can still be traced not only in the pulp and paper business but also in Finnish business journalism. With very few exceptions, this reporting insists on portraying the firms within a success-story narrative, leaving out the local societal costs that have made possible the accumulation of huge business profits. The developmental role the Finnish companies play in Brazilian society is not small and undetectable. By participating in massive pulp and paper operations, Stora Enso and the associated Finnish firms and export credit agencies comprise a powerful political and economic entity, critically influencing regional development processes, such as land reform. The firms not only influence local people's everyday lives in multiple ways, but they also have become gap-fillers for the public sector in a nation that is struggling with governance crises and discriminating against its Indigenous Peoples. The gap-filler situation also creates dependency on corporations and allows local governments to evade their responsibilities. The end result may also be interpreted as meaning that the Finns help support bad governance structures. They should be doing just the opposite: assuming a higher standard of ethical responsibility in Brazil's poorest regions.

In the light of this research, it appears that the philanthropy, at least, has become a dominant CCR framework in the corporate stakeholder approach and hence a tactic to seek societal acceptability and legitimacy. Consequently, the corporate disclosures of the Finnish companies have centered around philanthropic activities and "harmonious partnerships" with the local communities. The land question has been mentioned only briefly, if at all. The meetings with the caciques are highlighted in the company news but in a "territorial vacuum": it addresses what kind of assistance the company is offering or increasing to the participants' villages, but there is no mention of the land issue, which runs sharply counter to my research results. To sum up, the fact that the companies prefer to remain silent about the land question is understandable, given their growth logic. In their stakeholder policies, the Finns have taken a mainly dual approach. On the one hand, Stora Enso has shown interest in improving their stakeholder relations with local communities by increasing corporate philanthropy. On the other hand, the firms in general have passively accepted their Brazilian partner company's leadership and business practices and have also become entangled in the incidents related to Indigenous land claims. Within the scope of this research, it is impossible to ascertain whether the Finnish firms' stakeholder policies have been conscious. Nevertheless, the Finns have not publicly distanced themselves, either in Brazil or Finland, from Fibria/Aracruz's human rights violations and other harsh responses to the Indigenous protests. 
Hence it would be worthwhile for future studies to examine how firms themselves set boundaries for their CCR. How is the responsibility being "territorialized"? Do they consider the incidents with the communities to belong only to the Brazilian business partner's CCR territory? Is it acceptable that the supplying companies, such as Pöyry and Metso, can evade their responsibility by being mere "secondary" actors in the picture? For instance, Pöyry has indirectly contributed to the violent history and collective trauma of the Tupinikim, all of which followed the feasibility study and planning of the factory facilities in Fibria/Aracruz.

My research and its CCR model raise the question of whether corporate philanthropy is always a "good thing" or an adequate value in itself if there is no scrutiny of how corporations are carrying out their activities and how these fit the regulatory framework. I argue that if the most critical questions, the Indigenous land titles, are not proactively resolved, then the companies are unequivocally evading their fundamental responsibility and appear simply to be buying local acceptability and legitimacy through philanthropy. With regard to the data gathering in this type of research topic, the starting point should be the grasping of basic developmental questions - and concurrently of various CSR discourses - followed by fieldwork in the South. 


\section{DISCUSSION AND CONCLUSIONS}

In this final chapter I will revise my research by considering two more recent theoretical contexts. I will first reflect the research results through the prism of the international human rights system governing CCR. Next I will present the contemporary Latin American development discourses, where the alternative approaches to extractive capitalism, with the related Indigenous rights and natural resources, are introduced. Hence my research topic and approach, by bridging business ethics and development studies is very relevant in regard to the Latin American discourses. At the end of the chapter, I suggest some new research fields for CCR.

\subsection{The state, Indigenous rights, and corporations within the in- ternational regulatory framework}

\footnotetext{
States' international human rights law obligations require that they respect, protect and fulfil the human rights of individuals within their territory and/or jurisdiction. This includes the duty to protect against human rights abuse by third parties, including business enterprises. (United Nations, 2011, 8.)
}

The emergence of the United Nations Declaration on the Rights of Indigenous Peoples (UNDRIP) in 2007 brought up the need to establish international standards applicable for corporations when their business operations could impact Indigenous territories. There are plenty of international laws, conventions, standards, guidelines, and policies, such as International Labor Organization Convention No. 169; the United Nations Global Compact; International Financial Corporation (IFC) Performance Standard PS-7; World Bank Operational Policy on Indigenous People (OP 4.10); the Convention on Biological Diversity Akwé: Kon Guidelines (2004); and the general normative instructions of the UNDRIP. These documents expect corporations to conduct due diligence in operations and respect Indigenous rights. The responsibilities require corporations, before starting operations impacting any Indigenous community, to en- 
sure adequate awareness and respect both domestic laws and all international Indigenous rights standards that are binding on the states. In other words, CSR involves more than just following the national law. 44

Though there are many guidelines and conventions, they are scattered into numerous, mutually uncoordinated regimes and documents. This makes the CSR system complex and ambiguous and thus does not sufficiently guarantee secure positions for Indigenous Peoples. Moreover, there is a severe lack of concrete, specific, and effective international instruments and sanctions guiding the responsibilities of corporations vis-à-vis the Indigenous populations. This is due to the fact that the legal frameworks of most international human rights address only state responsibilities ${ }^{45}$. Since the state itself does not adhere to domestic laws, much less international agreements, a power vacuum has opened up, allowing the MNCs to step in and benefit from the unclear situation. The land disputes caused by a company's invasion of an Indigenous territory are a good indicator of this twisted process.

My case studies aptly illustrate the consequences of the above situations regarding regulation. In the research articles I introduced the basic regulative framework and legal challenges regarding Indigenous Peoples, whose juridical position is very complex, delayed, and insecure in Brazil. ILO Convention No. 169 is the most important operative international law that is meant to guarantee the rights of Indigenous nations. The Convention is a legally binding international instrument that deals specifically with the rights of Indigenous and tribal peoples; Brazil ratified it in 2004. Brazil has also signed the Universal Declaration of Human Rights; the International Covenant on Civil and Political Rights; the International Covenant on Economic, Social and Cultural Rights; and the UN Declaration on the Rights of Indigenous Peoples (IWGIA, 2014, 177).

Regarding the recent regulatory framework, the United Nations "Protect, Respect and Remedy" framework, the so-called Ruggie Guiding Principles (GPs), include a three-pillar framework that consists of the following principles: 1) the state duty to protect human rights, 2) the corporate responsibility to respect human rights, and 3) the need for greater access to remedy for victims of business-related abuse. (United Nations, 2011; 2012, see Table 4.)

44 http:// www.uanativenet.com/topicitem/corporate-social-responsibility-and-
indigenous-peoples (retrieved May, 2015).

45 Ibid 
TABLE 4 The Ruggie Guiding Principles (GPs) for corporate-Indigenous relations.

- The United Nations Declaration on the Rights of Indigenous Peoples addresses both the human rights of indigenous individuals and the collective rights of indigenous peoples (United Nations 2012, 13).

- In practice, some rights will be more relevant or salient than others in particular industries and circumstances, and companies will pay more attention to them. For example, the human rights risks that are most salient for enterprises in the apparel sector with products made by workers in factories across several countries, will differ from those of enterprises in the extractive sector that have to relocate an indigenous community. But there is nothing in principle that precludes any enterprise from causing or contributing to adverse impact on any internationally recognized human right. It is therefore not possible to limit the application of the responsibility to respect human rights to a particular subset of rights for particular sectors. (Ibid., 14)

- An enterprise's operational context can also make a significant difference. If labor laws are poorly implemented and enforced by the state authorities, then working with suppliers from that region will carry a higher risk of becoming involved in labor rights abuses. If the area is affected by, or prone to, conflict, there may be particular risks with regard to security, the right to life and ethnic discrimination. If the region suffers from water scarcity, then the risk of adverse impact on the right to safe water will be high. If the affected communities include indigenous peoples, then their rights, including their cultural rights, may be at particular risk. These factors of sector and operational context are therefore especially relevant, or salient, in determining which human rights are at greatest risk from a particular enterprise's operations. As stressed above, this does not mean they should become its exclusive focus. But they will likely need to be the subject of the most systematized and regular attention. (Ibid., 21)

- Engagement with stakeholders plays a number of roles. It enables an enterprise to identify whether stakeholders have the same or different perspectives (than the enterprise and than each other) on what constitutes an impact on their human rights and on how significant an impact may be. For instance, damage to land that belongs to an indigenous community but is not farmed or otherwise used for economic purposes might seem to the enterprise to represent a low-level impact on the right to property that can easily be addressed through financial compensation or the provision of alternative land; whereas an indigenous community may consider that there is a far greater impact related to the role of that land in its culture, traditions and beliefs. (Ibid., 45)

- There may be one or more kinds of State-based mechanisms that are appropriate for providing remediation if the enterprise cannot or should not do so itself. These obviously include the courts and may also include State ombudsman or complaints offices (sometimes specific to an industry), a labor standards office, a National Contact Point (in States that have signed up to the Guidelines for Multinational Enterprises of the Organization for Economic Co-operation and Development), a national human rights institution, or any other State-administered or statutory body empowered to take on this kind of role. They may also include local, traditional mechanisms used by indigenous or other communities. (Ibid., 65-66)

- ... It is fairly usual to have separate grievance mechanisms for direct employees and for external affected stakeholders, though it is not always necessary to separate the two. It may also be important to have tailored grievance mechanisms for particular situations, such as community resettlement, or for particular groups, such as indigenous peoples. However, the more streamlined the mechanisms, the more easily their effectiveness 
can be monitored, and the more successful they can be at identifying generalized patterns and trends in how the enterprise is addressing its human rights impact. (Ibid., 70-71)

- Depending on the operational context, the most severe human rights impact may be faced by persons belonging to groups that are at higher risk of vulnerability or marginalization, such as children, women, indigenous peoples, or people belonging to ethnic or other minorities. If the enterprise decides it needs to prioritize its responses to human rights impacts, it should take into account the vulnerability of such groups and the risk that a delayed response to certain impacts could affect them disproportionately. (Ibid., 84)

When we interpret the Ruggie Guiding Principles in the firms' operational context, we can scrutinize the role of the Finnish firms in Brazil: not only Stora Enso but also Metso, Pöyry, Valmet, and other related Finnish companies became entangled in land disputes involving human rights abuses through the collaboration with their Brazilian business partner, both in Espírito and Bahia. The consultants' and the supplier's positions in the CCR questions in the pulp and paper and other extractive sectors have not been debated much. For instance, Metso has attempted to evade corporate responsibility questions not only on the Brazilian Atlantic coast but also in the case of Belo Monte in the Amazon ${ }^{46}$. Compared to other business sectors, firms operating in the resource extractive field carry a higher risk of human rights abuses, as the GPs acknowledge. Moreover, whether in Bahia or Amazon, the Indigenous communities' overall rights are especially at risk, particularly those of children and youth.

Despite the above positive developments in the regulatory context of CCR, in my opinion the situation still allows too many loose interpretations of CCR questions in practice. Deva's (2012) article critically examines the implications of the Ruggie GP principles. It concludes that although GPs do not offer any ready-made solutions for human rights violations by corporations, they offer some guidance to certain companies, especially those with "good intentions," on how to run their businesses responsibly. Checking my results against the GPs after my research, I see many concurrent and relevant issues. Here are some of them: 1) the GPs acknowledge the diversity of risky areas; 2) they distinguish between various business sectors, since some are more likely to affect human rights than others - however, it is difficult to limit or direct selected human rights responsibilities to certain sectors; 3) the principles acknowledge the diversity of stakeholders and their opinions; 4) corporations value land differently or more one-dimensionally than Indigenous Peoples: land that seems to be vacant for business may have values other than merely economic ones. However, I problematize some GPs and corporate actions on the basis of my research findings by arguing that 1) the ombudsman and grievance systems may entail problems for community development (some groups may receive

46 Metso has argued that it is related to the Belo Monte project only indirectly, and that the company started collaboration when the project was already ongoing (T. Laakso, Belo Monten patohankkeen kiemurat ulottuvat Suomeen asti. Maailma.net, April 10, 2013). http:/ / maailma.net/artikkelit/belo_monten_patohankkeen_kiemurat_ulottuvat_suo meen_asti (retrieved April 11, 2013) 
more assistance) and credibility (no matter what mechanisms were created, the Brazilian state and the corporations seem to ignore the most important local grievances, which are frequently brought up in local consultations); 2) the vulnerable position of the Indigenous Peoples is rather well-known, but this makes no difference, since firms seem to treat their local stakeholders homogeneously, and 3) the Indigenous Peoples' rights to their ancestral lands, as soon as it has been identified by FUNAI (i.e., the first stage in the IT demarcation process), is clearly stated in the national laws and international conventions. I would argue that the corporations tend to intentionally ignore the meaning of this initial stage. Instead, the official registration (which lags behind in all cases) is used as the only one stage to be respected. A good example of this arbitrary, if not autocratic, interpretation of Brazilian laws and international conventions is the stakeholder policy run by Fibria/Aracruz and Stora Enso in Veracel's case. They continue operations normally and use the final stage of the Pataxó IT demarcation as an excuse for being passive in the land dispute question, when all along, prior to the establishment of the factory, these companies should have respected the territory that the FUNAI researchers had already identified in the 1990s. When my research findings were published in a Finnish business journal ${ }^{47}$, Veracel announced on its webpage ${ }^{48}$ :

First of all, it is important to know that Veracel does not own plantations or buy eucalypts from tree farms with land in demarcated areas. Veracel fully complies with all legally recognized [sic] indigenous lands and indigenous communities in its area of operation.

What is highly disturbing, in my opinion, is that a photo of an Indian boy with a smiling face is attached to the above response. This reinforces the stakeholder approach by the companies, which is explicitly promoted by depicting the youth. I believe that this corporate communicating practice seeking public acceptability is questionable in the framework of the Ruggie Guiding Principles. My conclusion is that the CSR policy contains a great discrepancy: while Veracel is apparently benefiting from a situation in which the state is not fulfilling its legal responsibility to the IPs, it is in stark contrast with the corporate communication assuring the public that Veracel is operating according to the laws - the corporate communication never mentions those laws that relate specifically to the Indians. (Image 8.)

47 L. Manninen, 2014, Tutkija: Stora Enson tytäryhtiö rikkoo lakia Brasiliassa. Taloussanomat June 13, 2014. http://www.taloussanomat.fi/porssi/2014/06/13/tutkijastora-enson-tytaryhtio-rikkoo-lakia-brasiliassa/20148350/170 (retrieved June 13, 2014).

48 http:// biomaterials.storaenso.com/news/veracel-in-the-media-indigenouscommunity- relationships-and-land-ownership (retrieved August 5, 2014). 


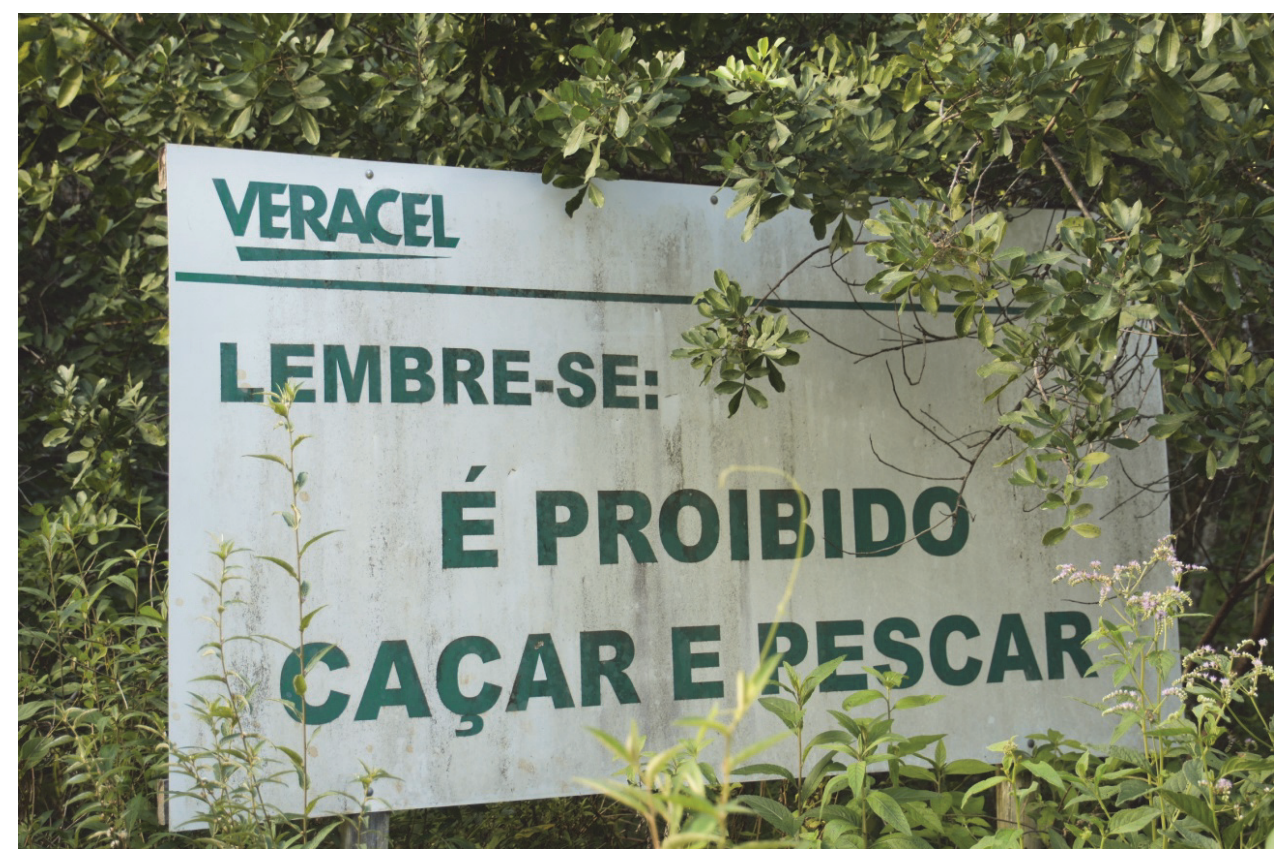

IMAGE 8 The roadsign by Veracel forbidding hunting and fishing (Photo: Susanna Myllylä). According to the definition of territory by UNDRIP and ILO Convention No. 169, Indigenous peoples have rights to "the broader territory, encompassing the total environments of the areas which they occupy or otherwise use, inclusive of natural resources, rivers, lakes, and coasts". However, these Indigenous territorial rights have not actualized in Bahia, since the movement and livelihoods of the Pataxó are restricted.

The ownership of natural resources and the protection of Indigenous Peoples' rights as a basis for the board representation of host communities is an interesting issue in solving CCR questions. Mujih (2012, 239-240) points out that the host community should be represented on the board of the company-an argument that is based on two grounds: 1) the host community can claim that they own the natural resources of their land, and 2) the community is affected by the operations performed by the company on their land. According to Mujih, this right can be found in two sources: first, in international legal instruments, and second, by the declarations of the host community itself. (Ibid.) Furthermore, the due diligence duty of corporations requires them to establish a benefit-sharing mechanism with the Indigenous community in accordance with international standards, especially regarding the Inter-American and Human Rights systems ${ }^{49}$ :

Corporations have a duty to seek every feasible and possible means to limit or mitigate adverse impacts of their activities on indigenous territory. But where due to some indispensable reasons the adverse effect is unavoidable, the indigenous people should be entitled to a just and fair compensation or redress ... The benefit-sharing

49 UANativeNet, http:/ / uanativenet.com/topicitem/Topics\%20In\%20Brief/381 (retrieved June 11, 2015). 
mechanism should be exclusive of just and fair compensation, and must be created in manner that follows indigenous priorities. These corporate responsibilities are now deemed a constituent part of the broad corporate duty to respect and comply fully with international human rights. For instance, many international financial institutions will seize project funding where corporations fail to obtain free prior and informed consultation with affected indigenous peoples. In addition, under the "duty of state to protect" principle of the Inter-American and European Human Rights systems, a state must ensure the peoples human rights are respected by corporations, otherwise the state will be held responsible for failing to prevent violations perpetrated by corporate entities. (Emphasis added.)

Along with the previously mentioned regulations and other responsibilities towards Indigenous communities, assessing and implementing the due diligence duty requirement in Veracel's case basically shifts it into a new level of responsibility. The national and international regulatory framework protecting Indian rights is strong but is not recognized in its entirety by the companies. On the contrary, the company uses this framework to present rather ambiguous statements, open to diverse interpretations:

Independent of the legal situation regarding the Indian land on the districts, where Veracel actuates, the company knows, respects and contributes as for the Indian causes ${ }^{50}$.

What do the abovementioned "knowing, respecting and contributing", or "Indian causes" actually mean in practice? This leads to a question first targeted at the corporate communication in stakeholder relations. Since the companies have unequivocally denied any human rights violations towards the Indians without detailed reference to the regulatory background-one may ask: on what ground are these claims based, and what is their juridical source? Could it even be said that the companies undervalue their shareholders and the wider public? These types of corporate disclosures advocating corporate actions may indicate the phenomenon in which multinational companies posit themselves as being above the national and international laws. Nevertheless, the overall situation in Bahia will ultimately be seen and assessed when the Pataxó IT is finally being officially registered, and the CCR process may contain elements similar to the reference case of Espírito Santo. To conclude, based on my research findings, I contend that the Finnish forest industry cluster has failed to recognize and hence to fulfill its CCR in terms of the regulatory framework guiding firms that operate in the regions inhabited by the Indigenous Peoples.

Both the theoretical and empirical contexts have naturally faced changes throughout this long research process. It has been challenging to keep up with the transformations taking place in the dynamics of corporate community relations. My aim has been to describe these changes; however, I cannot point out a specific occasion that profoundly affected my research setting. The twist that occurred in Espírito Santo when the land struggle came to an end could be con-

50 http://testemu.insix.com.br/en/relationship-with-the-community/indiancommunity/ (retrieved July 23, 2015). 
sidered the watershed, one that also affected the analysis of the reference case study.

To shift away from the Northern ethos, I have presented a Concentric CCR model for analyzing and guiding corporate community relations in the global South contexts. In other words, the theoretical implication of the model is to unfold the complexity in corporate community relations and hence advance our knowledge of these situations by adapting the elements of the model in the Southern societal contexts. The trustworthiness and the limitations of the methodological choices and the collection and analysis of data were discussed primarily in Chapter 2.4. With regard to the confirmability aspect, it should be noted that the model and other research results are based on a rather creative but logical and systematic methodology. Concerning the transferability of the Concentric CCR model, the meaning of the context (e.g., Halme, Roome, and Dobers, 2009), i.e., the generalizing aspect, can be raised. Although my research is rooted to the specific case studies and microhistories, I have endorsed my theoretical construction as a "model" to be used in other cases, based on the following arguments. First, by using the Grounded Theory method combined with the case study approach and ethnography, the empirical data extracted from local situations has been supplemented by the international background literature. Although many of the concepts I have used derive from the two Brazilian land-struggle case studies, I have complemented them with other relevant concepts from the background literature. The methodological challenge was to express people's views in more business-oriented language, even though the Indians themselves often used business rhetoric, which indicated encounters with the corporations. In addition, the observations on the local situations in Brazil helped me to enhance understanding of development dynamics related to the companies' societal roles. Hence I also regard the Brazilian case studies as illuminating a wider CCR phenomenon. Second, I am perplexed by the converse question: in spite of diversity in societal contexts, why are the encounters between the resource-extractive corporations and local communities so similar? This directs attention especially to the similarities in corporations' local influence, stakeholder tactics, and corporate disclosures they carry out. Hence certain patterns in corporate community interaction can be traced when reviewing the extant literature from the global South. The starting point is the typical situation of an asymmetrical relationship between the two actors. A good example is the phenomenon of community dependency created by corporate philanthropy, which, in turn, tends to weaken the communities' territorial claims-hence my model suggests the primacy of regulatory aspects. Regardless of how the listed subprinciples might vary in diverse contexts, I would argue that the most transferable element in my model is the concentric, hierarchical thinking. Third, my model is most applicable to cases where extractive industries face local territorial claims, or areas that seem to be a no-man's land in emerging or developing economies where regulations are weakly enforced and monitored. Fourth, concerning practical implications, the Concentric CCR model has a dual policy orientation: as a "road map" for corporations and a "shield" for the communities. 
The model's message to corporations is to "do more": instead of following the state actors in neglecting the rights of local communities, the companies should adhere to existing national and international regulatory frameworks.

\subsection{Latin American post-neoliberal alternatives to development}

Pluriverse is what needs to be sustained-a world where many worlds fit (Escobar, 2015).

The amount of CSR-oriented literature in Latin America is growing (see, e.g., Aguero, 2006). Durand (2006) scrutinizes business and CSR in the Peruvian case. Layton (2010) observes that Latin American corporate philanthropy is compatible with traditional Christian charity. However, although great wealth can be found in Latin America, philanthropy is relatively meager-Latin America is often cited as the most unequal region in the world. In Brazil, socioeconomic inequalities have constantly risen. Sanborn (2006) offers a historical outlook on philanthropy in Latin America. In order to make philanthropy more effective, she recommends that donors form alliances with public-sector partners, reflect on the root causes of social problems, and seek to strengthen civil-society groups among the poor. In the same vein, Macke and Carrion (2013; also Macke, Carrion, and Dilly, 2010) have looked at Brazilian companies that have gained a reputation as socially responsible by expanding the social capital in their communities. The authors argue that a CSR program can potentially contribute to local development if it includes the civic principles of the community and thus enhances the social capital in the local context. According to the authors, one of the central aspects related to CSR is the high expectation that companies will be able to solve the vast majority of social problems and social crises once they have management competence. (Ibid.) However, as studied in my third article, I argue that creating public-private partnerships is problematic, especially in the case of asymmetrical power situations between the company and community, since the company has a tendency a) to contribute to the social problems, and b) cause an institutional capture, undermining the neutrality of the state and its capacity to protect Indigenous communities. My research findings indicate that corporate philanthropy in the field of public services may lead to a situation in which the municipalities and the state withdraw from their responsibilities, leading to a local dependency on corporations. Social capital approaches are also problematic, since they tend to disregard the prevailing power structures within communities.

Argandoña (2011) reminds us of the deficiencies in the basic economic concept of "value" embedded in the CSR and stakeholder discourses. He contends that "so long as we confine ourselves to an exclusively economic concept of value (though it may be possible, at least in theory) to gain economic optima, sustainable, conflict-free management cannot be achieved because we will be omitting important aspects of reality". He proposes to broaden the concept of 
value, based on the core relationship between the company and its stakeholders, which allows the identification of a whole range of "values" that take stakeholder theory to a higher level. As the author points out, the company may transfer certain more or less explicit risks or costs to other stakeholders. Hence these and other problematic situations may affect other agents who are not directly related to the company's production process. For example, the company may assign part of the costs of pollution to other agents, and as a result, it will have earned a surplus that is not socially optimal. Argandoña notes that in a stakeholder model, the theory of value creation basically implies that any agent that suffers the impact of the firm's externalities or misinformation (e.g., local community, environment) must be considered stakeholders - at least for the purpose of value distribution. (Ibid.)

While the amount of CSR literature in the field of business economics is steadily increasing in the Latin American context, the development studies demonstrate a growing academic interest in the resource struggles simultaneously taking place in the region. I locate my research at the nexus of these two fields, where I attempt to bridge the two. At the end of this dissertation, I return to a point I made in the introduction: that this study is not just about examining how the pulp and paper industry contributes to the wealth of the Indians and their immediate environments in Brazil. It is fundamentally a question of how diverse lifeworlds encounter and coexist and how CCR is examined within a wider setting of development models and the attached worldviews.

In her critical study on the land struggle between transnational mining companies and local communities in Peru, Sullivan (2014) contends that many Latin American countries are currently coming out the "other side of the neoliberal tunnel exploring alternative economic models of development, with the rise of progressive governments sweeping the region". She criticizes Peru for its reliance on the neoliberal approach and notes "how extractive industry in that country embodies the essence of a stubborn and dangerous form of capitalism". Thus extractive industry has moved to the center of both economic and development debates. According to Gudynas (2011):

While a series of socialist, progressive or new left governments are found in the Global South (ranging from China and Vietnam, to Brazil and Venezuela), they present themselves as emerging economies that defend classical growth strategies, some exporting cheap goods, others trading natural resources.

Contemporary Latin American post-neoliberal development thinking rises from a quite surprising direction: from the Indigenous conceptions and belief systems, that is, the cosmovisions based on specific contexts and the related social movements: for example, the Aymara peoples of Bolivia, the Quichua of Ecuador, and the Mapuche of Chile and Argentina. Gudynas (2011) has looked at the main South American trends of the discourse around Buen vivir, a Spanish concept that means "living well" or "good living" and which describes alternative development in a broad sense. Behind the emergence of cosmovision can be found Latin American social movements that are reacting to the dominating development model's negative societal impacts: 
Early formulations of the Buen vivir emerged in reaction to classical development strategies, either due to its negative social or environmental impacts, or the debatable economic effects. Many critiques highlighted the shortcomings and negative impacts of development project implemented by governments and multilateral development banks in Latin America in the last decades. In the early 2000s, it was clear that instrumental fixes or economic compensation to balance the negative effects of current development strategies, were inadequate, and the classical development idea had to be abandoned... Although most of the early formulations of the Buen vivir were produced independently of those post-development questions, there are strong similarities, because they represent a radical deconstruction of the cultural base of development, its legitimating discourses, its applications and institutional frameworks. (Ibid.)

Quite interestingly, Gudynas points out that within several Indigenous cosmovisions in South America, a radical questioning has been possible: their cultures lacked concepts such as "development" or "progress." Thus he sees the contribution of Indigenous knowledge as a critical, continuous thread for the concept of Buen vivir. In addition, the term Buen vivir is actively used by social movements and by some government programs, like in Ecuador and Bolivia (ibid.). According to Gudynas, both translations of the term are located too close to Western notions of well-being or welfare:

These are not equivalents at all. With Buen vivir, the subject of wellbeing is not [about the] individual, but the individual in the social context of their community and in a unique environmental situation ..."[Buen vivir] is equally influenced by western critiques (of capitalism) over the last 30 years, especially from the field of feminist thought and environmentalism ... It certainly doesn't require a return to some sort of indigenous, pre-Colombian past. (See Balch, 2013.)

Gudynas (2011) looks at Buen vivir as a platform for different visions of alternatives to development. He argues that the paradox of development-that it can be declared as defunct and yet, in the next step, promoted as the only way forward - is deeply rooted in modern culture. Therefore "any alternative to development must open paths to move beyond the modern Western culture," for which Buen vivir offers an opportunity. Furthermore, he argues that the richness of Buen vivir makes it difficult to translate all of its aspects into English, such as the idea of well-being, which is only possible within a community, also including nature. The plural concept hence "embraces the broad notion of wellbeing and cohabitation with others and Nature." The concept has been interpreted differently in various cultural, historical, and ecological contexts in Latin America. Gomes (2000) suggests that the only long-term viable development option may be so-called "Indian mode of production," involving small-scale swidden agriculture with subsistence hunting/fishing/collecting.

Buen vivir (or in the Bolivian case, "Vivir bien") is referred to in the Andean region as Suma Qamaña. According to Gudynas, Buen vivir is also related to the cosmology of the Guaraní Indians, and their perceptions of "good life". The concept and its contemporary nature are supported by my research findings. While I was not yet aware of the Buen vivir discourses (which seem to have emerged during the end of my fieldwork), I notice that my approach has been similar in some ways: I asked about the cosmologies of the Indians, especially in 
regard to the Guaraní, who brought up the concept of yoy marãey, "the land without evil," in the context of the land struggle. But then what about Indigenous Peoples' knowledge and views of the CCR - could it be called Indigenous knowledge? This may not be an irrelevant question after all, since their responses and definitions of CCR contained hybrid elements from both the past and today (such as when the company has entered the old cosmovision). Hence my observation also confirms Gudynas's notion that Buen vivir is not about returning to the distant past: it is not a static concept but an idea that is continually being created. What, then, does Buen vivir have to offer when studying CCR in the global South? It implies at least two issues: first, by building an "ethnographical CCR miniature" (see Geertz, 1973, 21), which also requires a deep understanding of the Indigenous cultures and their languages: it is balancing between being open to individual and communal narratives, and finding and presenting the right questions in an understandable form. My research could be defined as an approximation of this approach.

Another interesting concept related to Buen vivir is pluriverse, introduced by Mignolo (2012). As he explains,

Western epistemology and hermeneutics managed universalize its own concept of universality dismissing the fact that all known civilizations are founded on the universality of his own cosmology ... The universalization of universality in the West was part of its imperial project. That is the universal can only be pluriversal, which also matched the Zapatista's idea of a world in which many worlds would coexist. We, in the planet, had arrived at the end of the era of abstract universals, that is of one universal universality... Pluriversality is not cultural relativism, but entanglement of several cosmologies connected today in a power differential. That power differential is the logic of coloniality covered up by the rhetorical narrative of modernity. Modernity is a fiction that carries in it the seed of Western pretense to universality... If a pluriverse is not a world of independent units (cultural relativism) but a world entangled through and by the colonial matrix of power, then, a way of thinking and understanding that dwells in the entanglement, in the borders, is needed. . $^{1}$

Escobar sees a movement from political ecology to political ontology in Latin American discourses. He has considered the pluriverse from the viewpoint of the political ontology of territorial struggles in Latin America. He has also explored possibilities for alternative visions for a post-development era by considering the design for transitions to the pluriverse. According to him socioenvironmental conflicts appear as ontological struggles, not only about economy but "fundamental struggles over what life is". Escobar states that many ethnoterritorial struggles can be seen as ontological struggles for the defense of other models of life, and they interrupt the globalizing project by fitting many worlds into one. Hence my research can also be positioned within the framework of ontological struggles. Escobar uses the Cauca movement in Colombia as an example, in terms of how they use "the language of the land " in which "territories are loved and not sold, but loved and defended". (See Escobar 2011.) Hence while the local communities may speak "the language of feeling", the dialogue does

51 http:// waltermignolo.com/on-pluriversality/ (retrieved June 30, 2015) 
not succeed since the corporations speak "the language of power" (see Isaacs, 1999, 208-211, citing Kantor and Lehr, 1975). However, there can be found mutual understanding:

When the Indians say that the headwaters of a great river is sacred, and when the government of Brazil says they must protect their watersheds, they are essentially speaking the same language (see Boyle, 2013).

But furthermore, the negotiations and struggles among diverse worlds are important encounters with economic and cultural transitions towards the pluriverse (Escobar, 2015). Hence we can also regard socio-environmental conflicts as a positive phenomenon: these struggles are the "avant-garde of the search for post-capitalist sustainable models of life" (ibid.).

In my research I have moved from merely presenting corporate dominance and asymmetrical power relations in the land struggles to "grassroots meaning-making with subaltern communities, to decipher and strengthen alternative systems of organizing, which re-define 'corporate responsibility'" (Mitra, 2011). To sum up, by presenting an alternative development vision for contemporary corporate dominance in CCR discourses, my research contributes to the idea of the pluriverse.

\subsection{Suggestions for future research}

As a main research result, I have proposed a CCR model for analyzing and understanding the complexities taking place in corporate community interaction, especially in situations where land resources are contested between global corporations and local communities. Next, the functionality and relevance of the model ought to be tested by adapting it to other case studies in the global South, especially in South America. Although the model offers a rather detailed and broad set of principles, it would be useful if the analysis is deepened and relevant indicators are created for the suggested principles. If possible, other principles could also be added.

With regard to the Finnish forest industry cluster, it would be worthwhile to examine the gray areas of CCR. What is the extent and the "frontier" of corporate social responsibility towards local communities? How do these boundaries manifest themselves, and what kinds of corporate decisions are they based on? In particular, the scarcely studied role of the firms "behind the scenes" (of the land struggle) -i.e., companies that carry out the planning and evaluation of pulpwood operations, and the machinery suppliers-deserve to be highlighted and hence to be incorporated more into the CCR debates. 


\section{YHTEENVETO (FINNISH SUMMARY)}

Tämän monitieteisen väitöskirjatutkimuksen tehtävänä on ollut selvittää miten Suomen metsäklusteriin kuuluvat yritykset ovat tulkinneet ja toteuttaneet yhteiskuntavastuuta suhteessa ulkoisiin sidosryhmiin Brasilian atlanttisella rannikolla. Espírito Santon ja eteläisen Bahian osavaltioihin on muodostunut laajoja, alati kasvavia selluntuotantoon muodostettuja eukalyptusplantaaseja alkuperäiskansojen territorioiden naapurustoon sekä osittain niiden alueille. Tutkimus syventää ymmärrystä kansainvälisten yritystemme paikallisista toimintaympäristöistä globaalissa Etelässä, kohdistaen samalla huomion yhteiskunnan heikoimmassa asemassa oleviin ryhmiin, ja näinollen korostuneeseen suomalaisyritysten sosio-ympäristölliseen vastuuseen. Tarkempi tieto Brasilian maakiistojen kompleksisista, paikallisista käänteistä, tai se yhteiskunnallinen hinta, jolla suomalaisia liikevoittoja saavutetaan, tavoittaa harvoin ellei ollenkaan suomalaisen talousjournalismin ja -diskurssit, jotka ovat keskittyneet yksipuolisesti käsittelemään Suomen metsäklusterin taloudellisia voittoja tai tappioita EteläAmerikassa.

Brasiliassa suomalaisyritysten investoinnit sijoittuvat monin paikoin seuduille, joilla on jo ennestään käynnissä maakiistoja eri toimijoiden kesken, ja joilla intiaanien perinteiset, identifioidut territoriot joutuvat odottamaan vuosikymmeniä virallistamistaan, johtuen Brasilian valtion tehottomuudesta. Tästä huolimatta Suomen metsäklusterin toimijat ovat ryhtyneet harjoittamaan liiketoimintaa näillä kiistanalaisilla alueilla, joilla köyhä väestö on lisäksi erityisen altis massiivisen teollisuustoiminnan vaikutuksille. Selluntuotanto on perinteisesti liitetty agribisneksen toimialaan. Tämän tutkimuksen valossa kyseessä on myös ilmiö, joka kuuluu intensiivisesti luonnonvaroja hyödyntävän sektorin piiriin.

Tämä väitöskirja muodostuu johdantoluvusta ja kolmesta artikkelista. Johdantoluvun tarkoituksena on ensinnäkin kiinnittää tutkittavat tapaukset yhteiskuntahistorialliseen, poliittis-taloudellliseen kontekstiinsa, minkä lisäksi tapauksia arvioidaan regulatiivisen viitekehyksen kautta. Taustoitukset auttavat osaltaan ymmärtämään syvällisemmin analysoitavia tapaustutkimuksia. Toiseksi, johdantoluvussa otetaan julkaistut artikkelit ja tutkimusprosessi kriittisen tarkastelun alle, samalla kun teoreettista viitekehystä päivitetään.

Tutkimuksessa on omaksuttu kahdenlainen käänteinen lähestymistapa, jossa ensinnäkin perinteisten ylhäältä-alas suuntautuvien, yrityskeskeisten teoreettisen määrittelyiden sijaan on lähdetty selvittämään kentälle Brasiliaan paikallisyhteisöjen antamia merkityksiä ns. vastuulliselle yritykselle. Tupinikim-, Guaraní- ja Pataxó-intiaanien kokemuksista muodostuu yritysten sidosryhmäsuhteiden ja -vastuun mikrohistoria, joka nostaa esiin toisenlaisen, harvemmin esiinnostetun kertomuksen Brasilian talouskehityksestä sekä Suomen metsäklusterin liiketoimintavastuun tavoista ja toteutumisesta. Toiseksi, tutkimusmetodologia muodostui yhdistämällä aineistolähtöinen lähestymistapa tapaustutkimuksiin. Brasilian kenttätyön tutkimusmateriaali kerättiin etnografisilla tutkimusmenetelmillä. 
Brasiliassa yritysten yhteiskuntavastuukysymykset suhteessa paikallisväestöön ilmenivät etenkin territoriaalisina kamppailuina; sekä retorisella että myös fyysisellä tasolla. Suomalaisyritysten koetinkivenä on ollut niiden operatiivinen ympäristö, brasilialaisen kumppanin epäeettinen toiminta, mihin suomalaisyritykset eivät ole tehneet selvää pesäeroa. Tutkimuksessa nostetaankin kysymys yritysten asettamien rajojen merkityksestä sen suhteen, mitkä asiat ne katsovat kuuluvan vastuunsa piiriin.

Tutkimuksen tulosten perustella voidaan todeta, että suomalaisyritykset eivät ole ottaneet toiminnassaan huomioon alkuperäiskansojen oikeuksia laajasti turvaavaa kansallista ja kansainvälistä lainsäädäntöä sekä ohjeistuksia. Esimerkiksi eukalyptusplantaasit muodostavat fyysisen esteen alkuperäisväestön elannonhankinnalle ja liikkumiselle, mikä puolestaan on ristiriidassa alkuperäisväestön oikeuksissa määritellyn ns. laajennetun territorion käsitteen kanssa.

Tutkimuksen keskeinen kontribuutio yritysten sidosryhmäsuhteiden tutkimukseen on siinä, että se pyrkii rakentamaan teoreettisesti ja metodisesti tiiviimpää yhteyttä yrityseettisen tutkimuksen ja kehitystutkimuksen välille, mikä on välttämätöntä globaalin Etelän tilanteiden ymmärtämiseksi. Työssä esitellään joukko uusia käsitteitä ( $\mathrm{mm}$. etnoterritoriaalisuus ja etnogenesis, kosmovisio, jne.), joilla yritys-yhteisösuhteita voidaan analysoida. Yritysten yhteiskuntavastuukeskustelun tarkentamiseksi tutkimuksessa esitetään yrityksen yhteisövastuun käsite.

Asymmetrisessä sidosryhmäsuhteessa yritys määrittelee ja päättää suhteen toimintamuodot, sekä tekee rajaukset, ketkä kuuluvat ns. kumppanuuden piiriin. Heikompi osapuoli on siten passiivisen vastaanottajan roolissa, ja vastarinta helposti heikkenee pienienkin etuisuuksien menetyksen pelon edessä. Tutkimuksen tavoitteena on tarjota teoreettisia ja metodisia välineitä näiden epäsymmetristen yritys-sidosryhmäsuhteiden dynamiikan analyysiin sekä myös ilmiön käytännön hallintaan. Tätä varten tutkimuksessa luotiin tiekartaksi yritysten yhteiskunta/yhteisövastuun kehämalli. Se on huomattavasti yksityiskohtaisempi, syvemmälle viety esitys verrattuna olemassaoleviin teoreettisiin viitekehyksiin. Mallin tavoitteena on vahvistaa sidosryhmän toimijuutta. Mallin hierarkia perustuu tutkimuksen johtopäätökseen, jonka mukaan yritysten tulisi lähestyä territoriaalisuuteen kiinnittyneitä paikallisyhteisöjä huomioimalla ensin yhteisön priorisoimat tekijät, kuten lainsäädännössä ja suosituksissakin viitatut territoriaalislähtöiset intressit, ja näinollen hyväntekeväisyyteen kuuluvien toimintojen tulee seurata vasta seuraavassa vaiheessa - ei ennen edellistä. Lisäksi malli kohdistaa kriittisyyttä niihin tapoihin, joilla hyväntekeväisyyttä yleensä harjoitetaan eli sen laadullisiin, yhteisöjen kehitykseen vaikuttaviin tekijöihin. Brasilian tapauksessa yhteiskunnallista hyväksyttävyyttä oli haettu nimenomaan hyväntekeväisyydestä käsin, millä puolestaan oli ollut yhteisöjä sekä niiden maaliikettä hajoittava vaikutus. Yritysten harjoittama hyväntekeväisyys ja sen laatu näyttäytyy tämän tutkimuksen valossa varsin epämääräiseltä, harmaalta alueelta, joka ansaitsee sekä lisätutkimusta että seurantaa. Jatkotutkimusaiheena ehdotetaan, että mallia sovellettaisiin ja testattaisiin etenkin sellaisten tapausten kohdalla, missä maakiistat ovat keskiössä. 
Tutkimus korostaa vaihtoehtoisten totuuksien ja näkemysten esillenostamista (pluriverse) länsimaisen, yhtä totuutta kantavan modernisaationarratiivin (universe) rinnalle, sillä nykyinen luonnonvarojen ylihyödyntämiseen perustuva kehitysmalli on kestämätön etenkin Etelä-Amerikassa. Brasiliassa Atlantin rannikolta Amazoniaan on tapahtumassa massiivinen ympäristöllinen ja sosiaalinen muutos. Sen ytimessä ovat uhanalaiset alkuperäiskansat ja viimeiset koskemattomat luontoalueet, joihin kohdistuvat lukuisat, samanaikaiset paineet etenkin kansainvälisten yhtiöiden taholta. Ketjureaktiot, jotka johtivat miltei koko Atlanttisen rannikkosademetsän katoamiseen, tapahtuvat nyt Amazoniassa - osin eri toimijoiden tahoilta, mutta sosio-ympäristöllisten vaikutusten ja konfliktien dynamiikka on perustaltaan samantyyppinen. Näinollen pohjimmiltaan tässä tutkimuksessa ei ole kysymys pelkästään suomalaisten selluntuotannon toimijoiden yhteiskuntavastuusta, vaan työn laajempi konteksti on vaihtoehtoisten talousmallien löytämisestä globaalissa Etelässä, missä olennaista on nimenomaan kehittää yritys-yhteisösuhteiden tutkimusta ja käytäntöjä. 


\section{REFERENCES}

Aguero, F. 2006. The Promotion of Corporate Social Responsibility in Latin America, in C. Sanborn and F. Portocarrero (Eds.). Philanthropy and Social Change in Latin America. Cambridge MA: Harvard University Press, $103-136$.

Albuquerque, F.S. de, Assunção-Albuquerque, M.J.T, Gálvez-Bravo, L., Cayuela, L., Rueda, M., and Benayas, J.M.R. 2011. Identification of Critical Areas for Mammal Conservation in the Brazilian Atlantic Forest Biosphere Reserve. Natureza \& Conservação, Vol. 9, No. 1, 73-78.

Andersson, M. and Barthholdson, Ö. 2004. Swedish Pulp in Brazil: The case of Veracel. Årsta, Sweden: Swedwatch.

Araujo M., Alger, K., Rocha, R., and Mesquita, C.A.B. 1998. Mata Atlântica do Sul da Bahia. Cadernos da Reserva da Biosfera da Mata Atlântica, No. 8.

Argandoña, A. 2011. Stakeholder Theory and Value Creation. IESE Business School Working Paper No. 922,

http:/ / papers.ssrn.com/sol3/ papers.cfm?abstract_id=1947317 (retrieved January 7, 2015).

Balch, O. 2013. Buen vivir: the social philosophy inspiring movements in South America, The Guardian, Feb. 4, 2013. Interview with Eduardo Gudynas. http://www.theguardian.com/sustainable-business/blog/buen-vivirphilosophy-south-america-eduardo-gudynas (retrieved August 2, 2015).

Banerjee, S. B. 2008. Corporate Social Responsibility: The Good, The Bad and The Ugly. Critical Sociology Vol. 34, No. 1, 51-79.

Bier, S. 2005. Conflict and Human Rights in the Amazon: The Yanomami. ICE Case studies, No. 19,

http://www1.american.edu/ted/ice/yanomami.htm (retrieved July 4, 2015).

Blaser, M., Feit, H.A., and McRae, G. (Eds.). 2004. In the Way of Development: Indigenous Peoples, Life Projects and Globalization. London, New York: Zed Books.

Boito, A. 2007. Class Relations in Brazil's New Neoliberal Phase. Latin American Perspectives, September 34, 115-131.

Borras, S.M., Franco, J.C., Gomez, S., Kay, C. and Spoor, M. 2012. Land grabbing in Latin America and the Caribbean. The Journal of Peasant Studies, Vol. 39, Nos. 3-4, 845-872.

Boyle, A. 2013. Amazon Indians go high-tech to map their land. NBC News, January 23, 2013.

http://www.nbcnews.com/id/3077244/ns/technology_and_sciencescience/t/amazon-indians-go-high-tech-map-their-land/\#.VbZjy_nsEdU (retrieved May 13, 2015).

Bresser-Pereira, L.C. 2012. Five models of capitalism. Brazilian Journal of Political Economy, Vol. 32, No. 1 (126), 21-32. 
Brønn, P. and Vidaver-Cohen, D. 2009. Corporate motives for social initiative: Legitimacy, sustainability, or the bottom line? Journal of Business Ethics. Vol. 87, 91-109.

Buchanan, D., Boddy, D., and McCalman, J. 1988. Getting in, getting on, getting out, and getting back, in A. Bryman (Ed.). Doing Research in Organizations. London: Routledge, 53-67.

Bueno, E. 2006. Náufragos, traficantes e degredados. As primeiras expedições ao Brasil. Coleção Terra Brasilis 2. Rio de Janeiro: Objetiva.

Bury, J. 2007. Mining Migrants: Transnational Mining and Migration Patterns in the Peruvian Andes. The Professional Geographer 59, 378-389.

Butler, R. 2014. Deforestation in the Amazon. July 9, 2014. http://www.mongabay.com/brazil.html (retrieved April 3, 2015).

Carroll, A.B. 1991. The pyramid of corporate social responsibility: Toward the moral management of organizational stakeholders. Business Horizons, July-August.

Cho, H.Y. 2000. Civic Action for Global Democracy: A Response to Neo-liberal Globalization. Inter-Asia Cultural Studies, Vol. 1, No 1.

Clark, D.A. 2002. Development ethics: a research agenda. International Journal of Social Economics, Vol 29, No.11, 830-848.

Clements, E.A. and Fernandes, B.M. 2012. Land Grabbing, Agribusiness and the Peasantry in Brazil and Mosambique. Paper presented at the international conference on Global Land Grabbing II, October 17-19, 2012. Land Deal Politics Initiative (LDPI). Ithaca, NY.

Dean, W. 1995. With Broadax and Firebrand: the Destruction of the Brazilian Atlantic Forest. Berkeley: University of California Press.

Deva, S. 2012. Guiding Principles on Business and Human Rights: Implications for Companies. European Company Law, Kluwer Law International, Special Issue on CSR and SRI. Vol. 9, Issue 2, University of Oslo Faculty of Law Research Paper No. 10, 101-109.

Devereux, S. and Hoddinott, J. (Eds.). 1992. Fieldwork in Developing Countries. New York: Harvester Wheatsheaf.

Diegues, A.C. 1994. The Mata Atlântica Biosphere Reserve (RBMA): An Overview. São Paulo: RBMA.

Durand, F. 2006. Business and Corporate Social Responsibility: The Peruvian Case, in C. Sanborn and F. Portocarrero (Eds.). Philanthropy and Social Change in Latin America. Cambridge MA: Harvard University Press, 191122.

Escobar, A. 2015. The Political Ontology of Territorial Struggles. Unpublished keynote speech at: 8th Conference of the Nordic Latin American Research Network (NOLAN), June 11 - 13, 2015, Helsinki, Finland.

Escobar, A. 2011. Sustainability: Design for the pluriverse. Development 54, $137-140$.

Evans, P.B. 1979. Dependent Development:The Alliance of Multinational, State, and Local Capital in Brazil. Princeton: Princeton University Press. 
Eweje, G. 2007. Multinational oil companies' CSR initiatives in Nigeria. The scepticism of stakeholders in host communities. Managerial Law, Vol. 49, No. 5/6, 218-235.

FASE. 2006. PAD International Seminar: Case Systematization, Eucalyptus/ Aracruz Celulose. Salvador.

Feiring, B. 2013. Indigenous Peoples' Rights to Lands, Territories and Resources. Rome: ILC Scoping Study.

Fernandes, B.M., Welch, C.A. and Gonçalves, E.C. 2010. Agrofuel policies in Brazil: paradigmatic and territorial disputes. Journal of Peasant Studies, Vol. 37, No. 4, 793 - 819.

Fernández, W.D. 2004. The grounded theory method and case study data in IS research: issues and design, Paper presented at the Information Systems Foundations Workshop: Constructing and Criticising, Canberra, Australia. http://epress.anu.edu.au/info_systems/part-ch05.pdf (retrieved January 2010).

Ferreira, S. R. B., Gonçalves, A. C., Machado S. L., Maracci, M. T., Mazzeto, C. E., Rocha, L. C., Sampaio, J. A. L., and Santos, M. L. F. 2010. Estudo etnoambiental Terra Indígena Tupiniquim e Terra Indígena Comboios, Anaí-BA, 3 volumes, Salvador, Brazil.

Fig, D. 2007. Questioning CSR in the Brazilian Atlantic Forest: the case of Aracruz Celulose SA. Third World Quarterly Vol. 28, No. 4, 831-849.

Filgueiras, T. S. and Peixoto, A.L. 2002. Flora e vegetação do Brasil na Carta de Caminha. Acta Bot. Bras. Vol. 16, No. 3, 263-272.

Finer, M., Vijay, V., Ponce, F., Jenkins, C. and Kahn, T. 2009. Ecuador's Yasuní Biosphere Reserve: a brief modern history and conservation challenges. Environmental Research Letters.Vol.4, No.3.

Frank, A.C. 1969. Latin America and Underdevelopment. New York: Monthly Review Press.

Galindo-Leal, C. \& Camara, I.G. 2005. Mata Atlântica: biodiversidade, ameaças e perspectivas. São Paulo: Fundaçao SOS Mata Atlântica, Belo Horizonte: Conservacão Internacional.

Geertz C. 1973. The Interpretation of Cultures. New York: Basic.

Gomes, M. P. 2000. The Indians and Brazil. Gainesville: University of Florida Press.

Gudynas, E. 2011. Buen vivir: Today's tomorrow. Development Vol. 54, No. 4, 441-447.

Halme, M., Roome, N., and Dobers, P. 2009. Corporate responsibility: Reflections on context and consequences. Scandinavian Journal of Management 25, 1-9.

Hamann, R. and Kapelus, P. 2004. Corporate social responsibility in mining in Southern Africa: Fair accountability or just greenwash? Development, Vol. 47, No. 3, 85-92.

IBGE. 2010. Atlas do censo demográfico 2010. http://loja.ibge.gov.br/atlas-do-censo-demografico-2010.html (retrieved July 1, 2015). 
Ioris, R.R. and Ioris, A. A. 2013. Assessing development and the idea of development in the 1950s in Brazil. Revista de Economia Política. Vol. 33, No. 3.

Isaacs, W., 1999, Dialogue and the art of thinking together. A pioneering approach to communicating in business and in life. New York: Doubleday.

IWGIA (The International Work Group for Indigenous Affairs). 2014. The Indigenous World. Copenhagen: Eks-Skolens Trykkeri.

Jenkins, H. and Obara, L. 2008. Corporate Social Responsibility (CSR) in the mining industry - the risk of community dependency. CRRC 2008 Conference 7-9 September 2008.

Kallio, T.J. 2007. Taboos in Corporate Social Responsibility Discourse. Journal of Business Ethics. Vol. 74, No 4., 165-175.

Ketola, T. 2010. European Forest Management Tracking Sustainability: Current Lacks. Knowledge Collaboration \& Learning for Sustainable Innovation ERSCP-EMSU conference, October 25-29, 2010, Delft, The Netherlands.

Kröger, M. 2010. The Politics of Pulp Investment and the Brazilian Landless Movement (MST). University of Helsinki, Faculty of Social Sciences, Department of Economic and Political Studies.

Kröger, M. and Nylund, J.-E. 2012. The conflict over Veracel pulpwood plantations in Brazil-application of ethical analysis. Forest Policy and Economics, Vol. 14, No. 1, 74-82.

Laakkonen, S. 1996. Roasted forests - Coffee and the history of deforestation in Brazil, in M. Palo and G. Mery (Eds.). Sustainable Forestry Challenges for Developing Countries. Dordrecht: Kluwer Academic Publishers, 229-247.

Laakkonen, S. 1992. Sivistyksen kipinä. Brasilian metsähistoriaa 1500-1992, in J. Pakkasvirta and T. Teivainen (Eds.) Kenen Amerikka?: 500 vuotta Latinalaisen Amerikan valloitusta. Helsinki: Gaudeamus, 201-218.

Lang, C. 2012. Veracel: "Sustainable on Paper" thanks to FSC. http://www.fscwatch.org/archives/2012/10/08/Veracel__Sustainabl (retrieved June 2, 2015).

Layton, M.D. 2010. Philanthropy in Latin America. International Encyclopedia of Civil Society, 1201-1209.

Lehtinen, A.A. 2002. Globalisation and the Finnish forest sector: on the internationalisation of forest-industrial operations. Fennia Vol. 180, No. 1-2, 237-250.

Leitão-Filho, H.F. 1987. Consideraçoes sobre a florística de florestas tropicais e subtropicais do Brasil. IPEF, n. 45, 41-46.

Macke, J. and Carrion, R. M. 2013. Do Corporative Social Programs Generate Social Capital? A Brazilian Case Study. EJBO - Electronic Journal of Business Ethics and Organization Studies, Vol. 18, No. 2, 30-37. http:/ / ejbo.jyu.fi/pdf/ejbo_vol18_no2.pdf (retrieved May 13, 2015).

Macke, J., Carrion, R., M., and Dilly, E.K. 2010. Programas sociais corporativos e capital social: proposta de qualificação. Vol.14, No. 5. http:/ / www.scielo.br/scielo.php?script=sci_arttext\&pid=S1415 65552010000500005\&lng=en\&nrm $=$ iso (retrieved March 3, 2015) 
Magnússon, S.G. and Szijártó, I.M. 2013. What Is Microhistory?: Theory and Practice. Abingdon, Oxfordshire: Routledge.

Marchak, P. 1995. Logging the Globe. Montreal: McGill-Queen's University Press.

Marcus, G.E. 1995, Ethnography in/of the World System: Multi-Sited Ethnography. Annual Review of Anthropology, Vol. 24, 95-117.

Mbare, O., Owusu, R. and Habiyakare, E. 2008. Implementing Corporate Social Responsibility in Africa: A Conceptualisation and Propositions' in Proceedings of the Leadership and Management Studies in Sub-Saharan Africa (LMSSSA) Conference.

Mignolo, W.D. 2012. Local Histories/Global Designs: Coloniality, Subaltern Knowledges, and Border Thinking. Princeton: Princeton University Press.

Miola, I.Z. 2010. Between Strictness and Flexibility: How Law Enables the Globalization of the Pulp and Paper Industry. El Norte - Finnish Journal of Latin American Studies. No. 5.

Mitra, R. 2011.“My Country's Future": A Culture-Centered Interrogation of Corporate Social Responsibility in India. Journal of Business Ethics, Vol. 106, No. 2, 131-147.

Mittermeier, R. A., Robles-Gil, P., Hoffmann, M., Pilgrim, J. D., Brooks, T. B., Mittermeier, C. G., Lamoreux, J. L., and Fonseca, G. A. B. 2004. Hotspots Revisited: Earth's Biologically Richest and Most Endangered Ecoregions. CEMEX, Mexico City, Mexico.

Monteiro, J. 1994. A Dança dos Números" in Tempo e Presença, São Paulo: CEDI, ano 16, n. 273.

Mujih, E.C. 2012. Regulating Multinationals in Developing Countries. Surrey: Gower.

Oliveira, K.L., 2008. O avanço do eucalipto no território de Extremo Sul da Bahía: recentes transformações na estrutura fundiária e o papel do crédito rural. MSc thesis, Economics, Univ. Federal da Bahía, Salvador.

Pakkasvirta, J. 2008. From Pulp to Fiction? Fray Bentos Pulp Investment Conflict through the Finnish Media. Cooperation \& Conflict, Vol. 43, No.4. Los Angeles: SAGE: 421-447.

Petras, J. 2013. Brazil: Extractive Capitalism and the Great Leap Backward, Global Research, July, 2013.

Prezia, B. 2002. Terra à vista: descobrimento ou invasão? São Paulo: Moderna.

Pyykkönen, M. 2007. Visual Construction of the Indigenousness. Finnish Lapland Travellers' Photographs of the Saami People and Culture. Arctic \& Antarctic Vol. 1, No 1, . 169-210.

Reed, D. 2002. Introduction. Journal of Business Ethics. Vol. 39, 199-226.

Ribeiro, M.C., Metzger, J.P., Martensen, A.C., Ponzoni, F.J., and Hirota, M.M. 2009. The Brazilian Atlantic Forest: how much is left, and how is the remaining forest distributed? Implications for conservation. Biological Conservation 142, 1141-1153.

Rizzini, C. T. 1997. Tratado de fitogeografia do Brasil. $2^{\mathrm{a}}$ Edição. Âmbito Cultural Edições Ltda, Rio de Janeiro. 
Sagebien, J. and Whellams, M. 2010. CSR and Development: Seeing the Forest for the Trees. Canadian Journal of Development Studies, Vol. 31, Nos 3-4, 483-510.

Sanborn, C. 2006. Philanthropy in Latin America: Historical Traditions and Current Trends, in C. Sanborn and F. Portocarrero (Eds.). Philanthropy and Social Change in Latin America. Cambridge MA: Harvard University Press, 3-30.

Sawyer, S. and Gomez, E.T. 2008. Transnational Governmentality and Resource Extraction. Indigenous Peoples, Multinational Corporations, Multilateral Institutions and the State. Identities, Conflict and Cohesion Programme Paper Number 13. United Nations Research Institute for Social Development.

Silva, J. M. C., and Casteleti, C. H. M. 2005. Estado da biodiversidade da Mata Atlântica brasileira, in C. Galindo-Leal and I.G. Câmara (Eds.). Mata Atlântica: biodiversidade, ameacas e perspectivas. São Paulo: Fundaçâo SOS Mata Atlântica, 43 - 59.

Skidmore, T. E. 1999. Brazil: Five Centuries of Change. Cary, NC, USA: Oxford University Press.

Skidmore, T. 2010. Brazil: Five Centuries of Change. Website to the 2010 second edition, published by Oxford University Press.

http://library.brown.edu/fivecenturiesofchange/(retrieved June 5, 2015).

Stora Enso. 2014. Stora Enso's Bulletin for Stakeholders, April 2014. http://assets.storaenso.com/se/com/DownloadCenterDocuments/Verac el_Bulletin_EN_16_April.pdf (retrieved June 18, 2015).

Strauss, A. and Corbin, J. 1990. Basics of qualitative research. Grounded theory procedures and techniques. London: SAGE.

Sullivan, L. 2014. Getting to the Bottom of Extractive Capitalism: A Case Study of Open Pit Mining in Cajamarca, Peru. Policy \& Practice: A Development Education Review. Vol. 19, Autumn, 124-143.

Sutherland, W.J. 2003. Parallel extinction risk and global distribution of languages and species. Nature 423, 276-279.

United Nations. 2011. Guiding Principles on Business and Human Rights. Implementing the United Nations "Protect, Respect, and Remedy" Framework. New Work, Geneva: United Nations.

United Nations. 2012. The Corporate Responsibility to Respect Human Rights. An interpretive guide. New York and Geneva: United Nations.

United Nations. 2013. Indigenous Peoples and Human Rights System. Fact sheet No. 9, Rev. 2. New York, Geneva: United Nations.

Urquhart, C. and Fernandez, W. 2006. Grounded Theory method: The researcher as blank slate and other myths, in D. Straub and S. Klein (Eds.). Proceedings of the Twenty Seventh International Conference on Information Systems, Milwaukee, USA, 457-464.

Virtanen, P. 2007. Changing Lived Worlds of Contemporary Amazonian Native Young People: Manchineri Youths in the Reserve and the City, BrazilAcre. Helsinki: University of Helsinki, Faculty of Arts. 
Watts, J. 2014. Brazil's Chainsaw Queen appointed a new minister, The Guardian. Dec. 24. http://www.theguardian.com/world/2014/dec/24/brazilagriculture - katia - abreu - climate - change (retrieved July 14, 2015).

Wheeler, D., Fabig, H. and Boele, R. 2002. Paradoxes and dilemmas for stakeholder responsive firms in the extractive sector: Lessons from the case of Shell and the Ogoni, Journal of Business Ethics, Vol. 39, No. 3, 297 318.

Yin, 2003. Case Study Research: Methods and Design. Thousand Oaks, Calif.: SAGE.

\section{Personal communication}

Azevedo de, T.R. , Director, Secretaria de Biodiversidade e Florestas Programa Nacional de Florestas, MMA/The Ministry of Environment, Brasília, September 2004.

Camargo, E., Lawyer, S.O.S. Mata Atlântica Foundation, São Paulo, September 2004.

Campolim, M., Director, Parque Estadual do Ilha do Cardoso, Cananeia, October 2004.

Ciccarone, C., Anthropologist, UFES, Vitória, December 2006.

Lino, C. S., CN - RBMA President, São Paulo, September 2004.

Maltez, H.M., Atlantic Forest Program Coordinator, WWF, Brasília, September 2004.

Mantovani, M., Director, S.O.S. Mata Atlântica Foundation, São Paulo, October 2004.

Neal, B., Executive Director, Atlantic Forest NGO Network, Brasília, September 2004.

Oliveira Costa da, J.P. , Secretário Nacional de Biodiversidade e Florestas do Ministério do Meio Ambiente, São Paulo, October 2004.

Ramos, A., Coordenadora de Politicas Públicas Socioambiental, Instituto Socioambiental, Brasília, September 2004.

Reed, P., Project Co-ordinator, Itamarajú, December 2006.

Schenkel, C.S., Coordenador de Ciencias e Meio Ambiente, UNESCO, Brasília, September 2004.

Simões, L.L., Ecoregião Serra do Mar, WWF, São Paulo, October 2004. 


\section{APPENDIX 1}

The Concentric CSR Roadmap model, which is presented in two stages: as a table, and as a concentric model. The outer circle, i.e., binding responsibilities, are described here by 'in which frames' questions, while the middle circle of ethical responsibilities refer to how something is done. In the inner circle, philanthropic responsibilities, it is basically a question of what is done, and it is primarily regarded as government's sphere of responsibility. Cultural context in the global South forms the model's 'meta-framework'.

\section{CULTURAL CONTEXT IN THE GLOBAL SOUTH}

\section{BINDING RESPONSIBILITIES}

'IN WHICH FRAMES' questions

(local, regional, national, and international laws, standards, regulations, certifications, constitutions, and conventions

\section{Territory}

-Investigate and respect officially registered host community's territory and its total environment.

-Investigate and respect traditional land and resource-related rights.

-Refrain from operating in areas where physical demarcation is in process.

-Avoid operations in disputed areas (e.g., with protracted legal battles).

-Avoid land grabbing or large-scale land acquisitions in regions with many small farms and wide-scale poverty.

-Avoid restricting people's traditional access to natural resources and their subsistence. Avoid destroying cultural sites and traditional pathways.

\section{Self-determination}

-Respect the self-determination right of the community in regard to all aspects (e.g., avoid interfering its cultural identity).

-People have right to participate to plans and decision-making, which may have impact on their lives and natural environment.

-No contact or interference at any level, whenever indicated or claimed by the community.

3. Dialogue

-Related to the community's self-determination right, pursue genuine negotiations with the community.

-Arrange meetings in the community's own terms.

4. Human rights

-Respect international human rights and Indigenous People's rights.

-Acknowledge the complexity of these rights, which may exist as natural rights or as legal rights, in local, regional, national, and international law.

-Use peaceful responses to local protests and resistance movements.

5. Working rights

-Respect national and international working rights (e.g., avoid racial and ethnic discrimination).

-Offer training and employment for the youth, if required by the community.

-Avoid using child and slave labor. 
6. Environmental and social impacts

-Respect environmental legislation, standards, and land zoning, despite their implementation and control systems have severe deficiencies in the host country.

-Respect healthy local living environments. Avoid causing land degradation, environmental pollution, overuse of resources, and loss of biodiversity. Do not disturb local food security and potable water resources

-Perform a high quality Environmental Impact Assessment (EIA).

-Perform a high quality Social Impact Assessment (SIA), whether or not it is mandatory.

Link it to the EIA.

7. Partners

-Acknowledge and investigate direct and indirect corporate impacts.

-'Know your partners': Avoid supporting or co-operating with repressive companies, local institutions and other actors, especially violence-prone security forces. Avoid business with land speculators inducing local conflicts.

8. Benefit-sharing

-Reasonable benefit-sharing with the community.

9. Compensation

-If corporate operations have already taken place in the community's lands, withdraw and prepare for reasonable financial compensation and restoration due to land degradation and other possible livelihood losses to the community, added to the land recovery costs (e.g., reforestation and purification of water resources).

II ETHICAL RESPONSIBILITIES

'HOW' questions

10. Equality and respect

-Respect people's livelihoods and homeland.

-Understand prevailing, difficult political, social, and economic contexts of the (often marginalized) community.

-Respect and learn from culturally different worldviews and knowledge systems.

-Realize genuine 'partnership'.

-Avoid patronizing approaches.

-Treat community leaders, subgroups, and members equally, in order to avoid a divisive impact on the community. Give special attention to youth and women.

\section{Trust}

-Make relations and agreements official; institutionalize.

-Keep promised responsibilities.

12. Diversity

-Support cultural, economic, and biological diversity among the community and its environment.

13. Sustainability

-Target sustainability of actions. Assist in ways other than offering material goods. Avoid community dependency and encourage local ownership.

-Maintain institutional knowledge on the community in spite of personnel changes in the firm.

14. Doing more

-Avoid making the host government's unfulfilled obligations to the community the scapegoat for adopting lower level business standards.

-Find alternative, innovative practices (e.g., to large-scale corporate farming).

15. Impact

-Assess community impact instead of listing mere actions and outcomes.

-Evaluate the impact of business practices, production, and CSR initiatives (e.g., in terms of project cycle) 
-Impact assessment is basically an overlapping element through which other ethical responsibilities can be viewed and analyzed.

16. Transparency

-Pursue transparency of actions and corporate reporting.

-Offer sufficient and understandable information for the community, as well as for the local, national and international audience.

-Openness concerning the impacts of business production, and CSR initiatives (e.g., social projects, benefit-sharing, local disputes, environmental or human rights violations, etc.). -Offer realistic and detailed information on local community relations and projects to the public.

-Indicate corporate learning from drawbacks and criticism.

-Use experts who are independent and whose fees are not disproportionate in comparison to the resources allocated to the community.

17. Credibility

-Transparency increases credibility.

-Seek collaboration with an independent, reliable third party.

18. Civil society

-Take the claims (norms) of the supporting civil society seriously. Respect the independence of research institutions, schools, and media.

III PHILANTROPIC RESPONSIBILITIES 'WHAT' questions

19. Basic services support, particularly in health care.

20. Support in employment and other forms of subsistence, particularly for youth.

21. Assistance to educational institutions and cultural activities.

22. Support in housing and infrastructure development. 


\section{Concentric CSR Roadmap Model}

\section{$\leadsto$ BINDING $\rightarrow$ ETHICAL $\rightarrow$ PHILANTHROPIC}

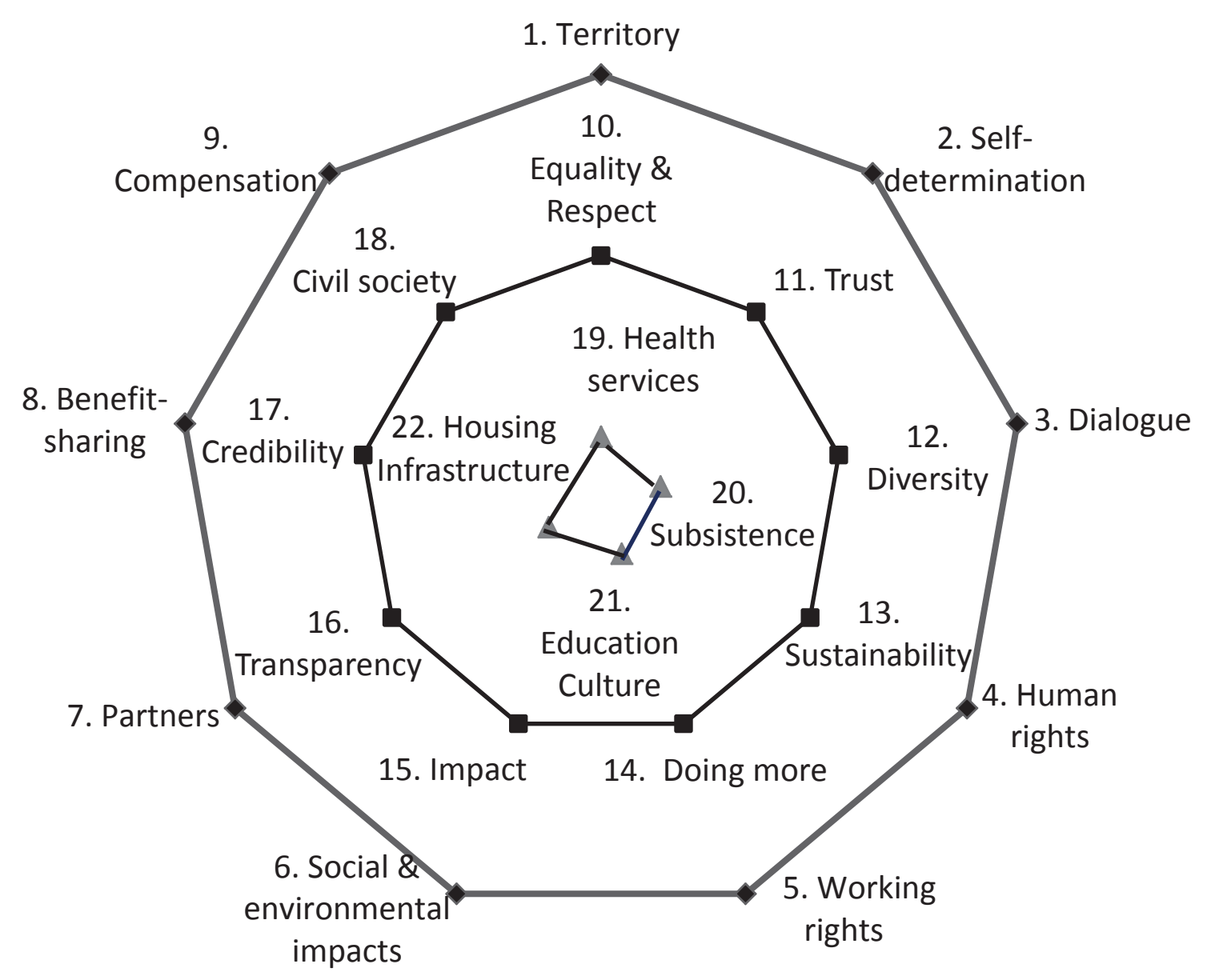

CULTURAL CONTEXT IN THE GLOBAL SOUTH 


\section{ORIGINAL PUBLICATIONS}

\section{I}

\section{ETHNOTERRITORIALITY CONFRONTING MULTINATION- ALS: INDIGENOUS PEOPLES' PERCEPTIONS ON EUCALYPTUS PLANTATION INDUSTRIES IN ATLANTIC \\ COASTAL BRAZIL}

by

Susanna Myllylä, 2010

Arctic \& Antarctic: International Journal of Circumpolar Sociocultural Issues Vol 4, No 4, 97-145 


\title{
Ethnoterritoriality confronting multinationals: Indigenous peoples' perceptions of eucalyptus plantation industries in Atlantic coastal Brazil
}

\author{
Susanna Myllylä \\ School of Business and Economics \\ University of Jyväskylä
}

\section{Introduction}

The areas of the indigenous peoples of Latin America have constantly diminished as multinational companies (MNCs) have entered to exploit their natural resources. Global companies often fail to take into account the prevailing poor socioeconomic conditions on the one hand, and the indigenous territories on the other, in countries where they set up branch operations. In Brazil, pulp production by multinational corporations is also linked to regional development and broader societal problems: the unequal division of land and natural resources, particularly where wealthy landowners and firms have taken over indigenous territories, and more recently, prepared them for sale to multinationals. Confronting these new powerful agents in their backyards, indigenous communities have had to create collective strategies to maintain their traditional territories and livelihoods. This also contributes to the creation of new identities and practices of reterritorialisation within their collective action.

In Brazil, what are now known as intensively managed planted forests ${ }^{2}$ (IMPFs) occupy six million hectares and are primarily eucalyptus for pulp. IMPFs occupy less than 0.65 per cent of the country's land base; however, the sector is predicted to expand in the near future. Brazil's pulp and paper sectors have grown rapidly: while in 2007 exports totalled 6.1 billion US dollars, the growth was then 18 percent, and another 12 percent increase was predicted by the end of 2008 . The expansion of the IMPF sector has primarily been concentrated in the Atlantic Forest region. (The Forests Dialogue 2008.) Agribusiness continues to occupy ever-greater land areas in Latin America, and particularly in the central and coastal regions of Brazil, which also fundamentally

\footnotetext{
${ }^{2}$ The critics argue that eucalyptus plantations are not forests, but large-scale plantations that have contributed to the destruction of Brazilian native forests.
} 
affects the region's economic, political, social and ecological development ${ }^{3}$.

Profound environmental change caused by intensive industrialisation has led to conflicting interpretations about the environment in Atlantic coastal Brazil. The fundamental problem is particularly within those indigenous territories that are not officially recognised and demarcated ${ }^{4}$, and this ambiguous status makes them especially vulnerable to the influence of MNCs. The Swedish-Finnish Stora Enso and Jaakko Pöyry Consulting, and to a lesser extent, some Finnish companies operating in the pulp sector have been entangled - through their Brazilian business partners, namely Aracruz Celulose S.A. - to the land conflicts in Atlantic coastal Brazil. The companies have exacerbated socio-economic injustice situations in the country's poorest rural eastern regions, which already have a very lopsided land ownership system, as well as severe human rights violations concerning the indigenous peoples (see United Nations 2005; Warren 2001).

This article is based on a qualitative research methodology using case study and discourse analysis approaches. Concerning the corporations, the data consists of written sources, business rhetoric and practical actions, such as public statements, corporate reports, public campaigns and personal communication. The main corporate tactics in gaining societal legitimacy, both in Brazil and in Finland, were identified and further categorised into thematic groups. Finally the tactics used in practice were compared to the companies' CSR principles, exhibited a great discrepancy between the two. (See also Myllylä and Takala 2011; Myllylä 2007.) In addition, the tactics from the other side were also analysed - the indigenous groups' various social or resistance movement strategies and their counter-arguments as they searched for legitimacy for their land claims. In other words, how they speak and act for themselves?

The empirical, primary data is based on three fieldwork periods in Brazil, during 2004 and 2006. I also include material from my previous research project when I studied the Atlantic Forest, its conservation systems ${ }^{5}$ and conflicts. Land dispute issues will be followed up with a new fieldwork phase in the near future. The field research material consists of interviews and personal

${ }^{3}$ Welch (2006) has studied Brazilian rural labour and agricultural history. He has analysed recent agrarian transformations associated with globalisation, including the organised response of workers and farmers to the loss of millions farm livelihoods. This development explains the rise of an autonomous peasant movement in the late twentieth century and the agricultural capitalist (or neoliberalist) model promoted by powerful agribusiness interests (see also Kröger 2008; CAPOMA 2009; Holden and Jacobson 2008).

${ }^{4}$ Out of Brazil's 988 indigenous lands, so far only 366 have been registered, also 665 are in various stages of official action and the rest, 323 are without any process (CIMI 2009).

${ }^{5}$ It is declared a global biodiversity hotspot by UNESCO: The Atlantic Forest Biosphere Reserve (Mata Atlântica BR). My research in Brazil has focused on the four eastern states: Bahia, Espírito Santo, Rio de Janeiro and São Paulo. The Atlantic Forest stretches from the northern state of Rio Grande do Norte, to Rio Grande do Sul in the south. 
observations among numerous parties or actors: the indigenous communities, various levels and sectors of authorities, civil society organisations and local researchers. Ethnographic research material was collected among the indigenous communities. Here I look at three indigenous groups: in the state of Espírito Santo (ES), the Tupinikim, who have become allied with the Guarani, and in the state of Bahia (BA), the Pataxó - all whom share a rather common background concerning their territorial claims, and experiences of pulp production by two multinationals, Aracruz Celulose S.A. and Stora Enso/Veracel Celulose. So far my research has mainly focused on the Tupinikim/Guarani issue; however, my aim is to also carry out further field research among the Pataxó. Instead of examining the internal power relations among and between these indigenous groups, my viewpoint focuses on the complex relationships between the indigenous communities and the multinationals, especially scrutinising: i) those changes the companies have caused in their livelihoods and cultures, and ii) the land dispute power struggles.

\section{The tactics of knowledge politics, new social movements and ethno- territoriality}

In spite of some internal problems among and between the Tupinikim and the Guarani in Espírito Santo state, both tribes have shown the capacity to operate as an alliance in the land dispute issue. Their resistance represents a New Social Movement (NSM), which commonly arises from a certain incident created by a social injustice situation. The structure of the NSM comprises actors from local, national and international levels, non-governmental organisations (NGOs) in particular ${ }^{6}$. Thus, indigenous peoples can also be transnational when they network with international actors. NSMs are "new" in the sense that they a) challenge dominant power structures; b) imply some radicalism; c) include an awareness of the past; d) involve new dimensions of identity, including personal aspects of human life; and e) represent alternative values (Doyle and McEachern 1998: 56-61). According to the Tupinikim leaders, "we have to keep up voice, also internationally, since if our issue is ceased, we are gone". In Bahia, the Pataxó Indians have used similar collective actions, although the land dispute issue there has not been as intensive as in the case of Espírito Santo.

Pramod Parajuli (1991) states that one of the major tasks of the NSM is to develop knowledge systems, which represent the experiences of the marginalised groups, such as indigenous peoples.

\footnotetext{
${ }^{6}$ In this case various levels of networks are, for example: Rede Alerta Contra o Deserto Verde, Movimento dos Trabalhadores Rurais Sem Terra (MST), Fórum em Defesa dos Direitos Indígenas (FDDI), Comissão Pastoral da Terra, Brigada Indigena, World Rainforest Movement (WRM) and NGOs from Europe, Robin Wood, among others.
} 
These systems use alternative ways to produce and justify knowledge, aiming at challenging the prevailing power structures and knowledge traditions, as in the case of Western scientific knowledge. It is not only a question of political and economic autonomy, but power to define the group and its needs, including the entire development process, such as survival, progress, identity, health, nutrition, time/space and the human-nature relationship (ibid.). In the long-term, the process of the land struggle, the revival of traditional cultural features and the resulting new ethos among the Tupinikim in particular has been illuminated in the campaign discussions and rhetoric. The Indians have claimed transparent public administration and equal treatment as citizens. Their tactics and alternative expertise are well representative of those typically used within the NSMs: protests, land/space occupations, "self-demarcations", use of civil society networks and improving the movement's discursive capacity (articulação, as they often refer to).

When comparing the rhetoric and actions of the different parties in the land conflict situations, there is a great discrepancy between the global company and the indigenous community in terms of how the reality and "justice" are perceived. The Indians' rhetoric based on their life-world experiences and cosmologies has been left without any attention. According to campaign statements by the Tupinikim, their collective trauma since 1967 (due to Aracruz's initial violent invasion in the area) has obviously been replicated in later violent incidents by the company. This phenomenon of traumatised communities - the feeling of losing control over one's life in the face of "collective disaster" - has been observed among various indigenous communities that have lost their livelihoods, often due to an external factor (see Erikson 1994: 230-231). Linda Tuhiwai Smith (1999) addresses corporations using technological advances and their failure to recognise indigenous belief systems and knowledges, especially in regard to ecologically related issues. James Carrier (2004) points out that situations, where local communities encounter powerful discourses arising from outside, they have to interpret the debates correctly and participate in them actively in order to be credible and protect their interests. Hence, with the help of supporting institutions and civil society organisations, the Indians could also have fine-tuned their argumentation or articulation to the "same level" as the global company in order to acquire more credibility and acceptability in the society; for instance, technical scientific reports proving the historical existence of the Tupinikim or the Pataxó on their traditional lands.

In the land conflicts with the MNCs, it could be argued that the indigenous peoples' territories, livelihoods and identities have been mutually recreated via the processes of ethnogenesis and ethnoterritoriality. By the latter, central theoretical concept, I refer to the indigenous communities' struggles for maintaining their traditional cultures and practices, which are profoundly attached to a 
certain locality: the identity and entire subsistence of a community is based on the land and its resources. Thus, it could be said that the claims and mobilisations of these communities have a geographical underpinning or spatial reference, which manifests especially in conflict situations, where land is contested (see also Moreno, 2000: 63). The land disputes with the MNCs have fundamentally affected the identities, social cohesion, and even worldviews of the indigenous communities as shown here. The Brazilian anthropologist, Sandro da Silva, whose research has focused on the Tupinikim community, argues that the Tupinikim are in the middle of an ethnogenesis, in which new identities are created in time and space, critically affected by the land dispute with Aracruz Celulose (Silva 2006, pers.comm.; see also Castro Ossami de Moura 2008). The ethnogenesis can be seen as a process of both a social and symbolic struggle (Barreto 1992, in Silva 2001). In a way, while the Tupinikim and the Guarani have fought to regain their territory and plan to even rejuvenate its natural resources, their ethnic identity is also being revived through the combination of traditional practices in response to contemporary elements.

\section{The changes in the Atlantic Forest as livelihood for indigenous peoples}

The indigenous peoples in the eastern coast of Brazil have derived their subsistence from the Atlantic Forest (Mata Atlântica), its land and water ecosystems long before the arrival of the Portuguese in the $16^{\text {th }}$ century. The principal indigenous groups along the coastline were then TupíGuaraní. The Atlantic Forest includes various types of interconnected ecosystems including tropical and subtropical rainforests, evergreen trees, araucarias, mangroves, and those known as restingas, which are low forests growing on stabilised coastal dunes.

The Atlantic Forest once covered 1.3 million $\mathrm{km}^{2}$ (15 per cent of Brazil), but due to intensive urbanisation and industrialisation in the coastal region, it has been reduced to a mere 7 percent of its original size, and now comprises tens of thousands of fragmented forest islands. Currently, this "biodiversity mosaic" is the second most endangered tropical forest in the world (after the Tropical Andes). It is characterised as one of the "global hotspots" since it has an exceptionally high diversity of endemic species that are found nowhere else on Earth. The Southern Bahia's rainforest fragments are regarded as the globe's richest in terms of the number of tree species per hectare: even 476 different tree species can be found on just a single hectare plot of forest. In addition, even today new primate species can be found in the heavily deforested, northern states such as Pernambuco. (Lino 2004, pers.comm.; Galindo and Gusmão 2003; Thomaz and Monteiro 1997). 
The northeastern forests have been drastically diminished to some 2-4 per cent, due to historical development comprising intensive logging, plantation and cattle economies (see Dean 1995).

Yet large continuums of forests still exist especially in the southern coastal states, where at the same time, the pulp companies seek to build new factories. In the conservation of the Atlantic Forest, a central idea is to protect the forest islands and connect them by using ecological corridors. Any type of monoculture plantation poses a threat for the recovery and conservation of the already fragmented forest. (Oberlaender 2006, pers.comm.) In addition, pulp industries cause complex socio-ecological chain reactions, in which the poor, landless farmers have to move to the fringes of the forest, leading to further deforestation of the Atlantic Forest. Strict conservationists are for a "zero logging" policy and run campaigns to reduce numerous illegal activities that constantly decrease the extremely vulnerable forest. It appears that civil society is somewhat divided into environmentally (e.g. Fundação SOS Mata Atlântica) and socially (e.g. FASE, ISA) oriented NGOs, in which the former often see that not even the indigenous communities should be allowed to live within the protected $\operatorname{areas}^{8}$ : not all indigenous communities use sustainable livelihood practices and the Atlantic Forest is critically endangered (Camargo 2004, pers.comm.). For the environmental authorities the situation is very tricky because the rights of the indigenous peoples have higher status compared to even strictest protected areas (Azevedo 2004, pers.comm.; Campolim 2004, pers.comm.). As the indigenous communities cannot be evicted from the parks, the state governments have attempted to direct and restrict the continuous regional movement of the Guarani. There are numerous Guarani communities living in the fringes of the cities like São Paulo.

Hence, pulp production - heavily supported by the Brazilian government with various incentives is both directly and indirectly causing deforestation in the Atlantic Forest, and this is critically affecting the livelihoods and cultures of the indigenous peoples. They have been forced into unproductive lands and poor living conditions. The communities depend on subsistence agriculture, fishing, crafts and other minor commercial activities. Unemployment and the lack of subsistence, especially among the Tupinikim, is high. Some of the Pataxó use endangered Atlantic Forest species of trees from the surrounding protected forests (national parks of Monte Pascoal, Descobrimento and Pau Brasil) for tourist crafts, while others prefer more sustainable forest use

\footnotetext{
${ }^{8}$ The NGO representatives interviewed in 2004 and 2006: E. Camargo and M. Mantovani (Fundação SOS Mata Atlântica, São Paulo); W. Overbeek and M. Cavalcantes Soares (Federaçao de Orgaos para Assistencia Social e Educacional / FASE, Vitória, ES); F. Zanirato (Instituto Socioambiental / ISA, São Paulo); H. Maltez and Luciana L. Simões (World Wide Fund For Nature, Brasília \& São Paulo); P. Reed from Flora Brasil (Itamarajú, BA), and B. Neal (Rede de ONGs da Mata Atlantica, Brasília).
} 
practices. Hence this is one example showing that the indigenous communities are not a single homogenous group, which merely uses sustainable livelihood methods.

My field research from 2004 to 2006 indicated that the eucalyptus plantations of Aracruz Celulose have had a multitude of negative impacts on Espírito Santo indigenous communities, such as a) cultural (weakening of community cohesion, language skills, and traditional customs etc.), b) economic (unemployment, loss of subsistence agriculture), c) social (drug abuse, new diseases) and d) environmental (loss of forest, drying of land, loss of animal species, water pollution), particularly for the Tupinikim, but also for the more isolated Guarani. During the 2006 fieldwork in Bahia, the Pataxó pointed out a number negative social and environmental impacts following Stora Enso/Veracel Celulose's arrival (see also Instituto Observatório Social, 2005), which are quite similar to those experienced by the Tupinikim and the Guarani. (Myllylä 2007.)

In various critical studies, both Brazilian and international, on the societal effects of pulp production it is argued that industrial tree plantations increase rural poverty and skew land ownership as pulp corporations become powerful landowners and thus also political forces. Pulp production units require gigantic land areas and also well-educated professionals who are often brought from outside the region. The pulp production sector creates poverty pockets out of rural communities, which cannot (or do not want to) become involved in this modern and highly mechanised production, particularly in the case of women in traditional communities, who have organised numerous resistance movements (see Barcellos and Ferreira, 2007; Santana 2004, pers.comm.). Community forests, farmlands and parts of the villagers' rotational agricultural systems are easily described as "degraded" by forestry experts and plantation proponents. When land is converted to tree plantations, local livelihoods are destroyed. (See e.g. Lang 2008; De'Nadai, Overbeek and Soares 2005; Carrere and Lohmann 1996.) Epitomising numerous social resistance movements against pulp industries in this coastal region, hundreds of rural women from the southern coastal area invaded a plantation belonging to Aracruz Celulose in 2006. The movement was organised to denounce these multinational companies, which in various parts of the country have displaced indigenous peoples and other traditional people, namely Afro-Brazilian Quilombos (communities descended from escaped-slave settlements) and other landless peasants. Pulp corporations have also caused severe environmental contamination with the intensive use of agro-toxins as well as the depletion of forest resources (Ribeiro 2008). In the following chapters I will examine more closely the various impacts of pulp production on indigenous peoples' lives. 
The multinational companies concerned here are the Brazilian Aracruz Celulose S.A. (previously of Brazilian-Norwegian ownership) and Veracel Celulose. The latter is a joint venture formed by Aracruz Celulose and the Swedish-Finnish Stora Enso, in which both own a 50 per cent stake. In September 2009, the ownership of both companies was changed: it was announced that Aracruz had merged with its Brazilian rival, Votorantim Celulose e Papel (VCP). Fibria, the new company, was a result of the acquisition of Aracruz Celulose by VCP, through its holding company, Votorantim Industrial. It holds a 29.3 per cent stake, while the Brazilian National Economic and Social Development Bank has 34.9 per cent, and 35.8 per cent is a free float. The new, larger company has a production capacity exceeding 6 million tonnes of pulp and paper annually, and about 90 per cent of the pulp is produced for export. (Fibria 2009.) In this paper, I will discuss the situation before this recent merging of the two companies.

Aracruz has been the world's leading producer of bleached eucalyptus kraft pulp, which is used by paper manufacturers to produce a wide range of products, such as tissue, printing and writing papers and specialty papers. Sales to customers outside Brazil, especially in North America, Western Europe and Asia, has accounted for 98 per cent of total sales volume. Aracruz's nominal bleached hardwood eucalyptus pulp production capacity, totalling 3.2 million tons a year, is distributed between three pulp making units: Barra do Riacho in Espírito Santo (2.3 million tons), Guíaba in Rio Grande do Sul (450,000 tons) and Veracel Celulose in Bahia (450,000 tons, or 50 per cent of the unit's total capacity). This corresponds to over 30 per cent or a third of the entire global supply (Aracruz Celulose 2009; International Finance Corporation 2009; Aracruz Celulose 2005.) In addition, the company has run a Forestry Partners Program that involves approximately 96,000 hectares contracted in partnership with more than 3,900 farmers in the states of Espírito Santo, Bahia, Minas Gerais, Rio de Janeiro and Rio Grande do Sul (Aracruz Celulose 2009).

In Bahia state, the Veracel (Aracruz-Stora Enso) project led to a series of contracts for European and Nordic companies. Jaakko Pöyry Consulting produced a range of feasibility studies and an environmental impact assessment. Metso Automation (a subsidiary of Finnish company Metso Corporation) won a US\$7 million order to supply valves and online analysers; Partek Forest (Finland) won a US\$25 million contract, its largest ever, to deliver harvesting equipment to Aracruz and Veracel. Pöyry’s Brazilian subsidiary Jaakko Pöyry Tecnologia Ltd subsequently won US\$16 million in engineering contracts on the construction of the Veracel pulp mill. (Lang 2008, 31-32.)

In 2005, Veracel's pulp mill started operations in the municipality of Eunápolis, south of Bahia. Veracel Celulose has an annual capacity of 900,000 tons of bleached eucalyptus pulp. (Aracruz 
2008.) The company's total land area of 164,600 ha is distributed in ten municipalities in the south of the state of Bahia. Plantations occupy 90,870 ha (Soikkeli 2009, pers.comm.). The rest is destined for environmental recovery and preservation, and a minor percent for infrastructure. Veracel's Forestry Partners Program has contracts with farmers to grow eucalyptus on an area covering a total of 10,000 hectares. (Veracel Celulose 2009a; 2009b.)

\section{The land struggle and attempts to make Indians better citizens}

In the $16^{\text {th }}$ century, the Tupinikim already occupied a large coastal territory, reaching from the southern part of Bahia and Paraná, including Espírito Santo, Rio de Janeiro, and São Paulo. The area between Espírito Santo and the south of Bahia supported 55,000 Tupinikim. In Espírito Santo State (Barra do Riacho area), the Tupinikim had settled their forefather's lands and lived in 44 indigenous areas - aldeias or villages - comprising 30,000 ha of the original Atlantic rainforest. (Executive Commission of the Tupinikim and Guarani 1996: 11, 39; see also Langfur 2006; Whitehead 2000.)

Land is usually the most central issue determining indigenous peoples lives, and this is also true for the indigenous peoples in Atlantic coastal Brazil. They consider that the land belongs to them since their forefathers have lived there for centuries. They still refer to the land document, which was given by the Portuguese crown in 1610. When the Portuguese colonialists first arrived, the Tupinikim had to accept the official program of mission villages organised by the Jesuits. They brought about a restriction of freedom for the Tupinikim: they were not able to express their culture, rites and traditions, and had limited access to the land they had traditionally occupied. In 1610 Father João Martins received a "sesmaria" on behalf of the Tupinikim. It was a piece of 'abandoned' land, which the Portuguese crown granted to the colonists to be cultivated. The sesmaria was granted to the Indians and covered a much wider area than has been contested between Aracruz and the Indians today. In 1760, the Portuguese crown demarcated the area inhabited by the Tupinikim, which was also confirmed by travellers such as Wied-Neuwied (1817) and Auguste de Saint-Hilaire (1818). (Executive Commission of the Tupinikim and Guarani 1996: 12-14.)

Prior to Aracruz Celulose in the 1940s, the local government in Espírito Santo State allowed an iron company, COFAVI (Cia Ferro e Aço de Vitória), to use an area of natural forest of 10,000 ha to produce coal. Aracruz Celulose arrived in the area in 1967 when it purchased this forest area from COFAVI and a larger area of 30,000 ha from the federal government. Aracruz's land purchase in an 
area that was already inhabited by two indigenous Indian groups - the Tupinikim and the Guarani was assisted by the military regime and some opportunist land speculators and politicians. Originally the company's name was Aracruz Florestal. (Executive Commission of the Tupinikim and Guarani 1996.) Just before the arrival of Aracruz in 1967, a group of Mbýa Guarani Indians from the south had settled close to the Tupinikim aldeia of Caieira Velha. They accepted the Guarani group as new neighbours due to a mutual solidarity among the Indians, and also because the Guarani considered that their ancestors had lived in the region.

In 1967, 60 per cent of the natural forests were still left in the Aracruz Municipality. The company immediately started massive operations to establish new eucalyptus plantations on what were considered indigenous lands by the Indians. First, the company's tactics, with the permission of the authorities, involved the use of violence and burning down the majority of the Tupinikim aldeias and evicting the population from the area. The remaining few decided to stay and survive in the remaining villages. The incident, still well remembered by the elders of both tribes, caused a critical dispersal of the Tupinikim community and ended their traditional hunter-gatherer and fishing activities.

One older Tupinikim woman remembered the moment when bulldozers came and they were connected by heavy iron chains, by which the rainforest was dragged down. Aracruz contracted the Finnish company Jaakko Pöyry Consulting to plan the pulp mill and its plantations. The next step in founding a plantation was also straightforward when the remaining flora and soil were erased by agrotoxins, which helped to make a flat and stable growing ground for eucalyptus seedlings. As the original thin layer of rich soil was left, more agrochemicals such as fertilizers were needed.

The Indian leaders travelled to the capital Brasília to denounce the invasion of their lands by the company to the former Indian Protection Service that is currently the Brazilian National Indian Foundation, FUNAI (Fundação Nacional do Índio), a protection agency for Indian interests and their cultures. Yet the reaction to the incident was quite the opposite of what the Indians expected: at the beginning of the 1970s, FUNAI started to transfer all the Guarani and some of the Tupinikim to the Indian Reserve in the Minas Gerais State, famous of slave work and prisons. Since the Tupinikim and the Guarani had always lived in the vicinity of the sea, they felt very uncomfortable in central Brazil. The Guarani chief (cacique) stated that they perceived a strange mixture of different Indian tribes and also, a punishment: "We were taken to fazenda guarani as if it was a jail". According to a Brazilian anthropologist Celeste Ciccarone, who has studied the Guarani community, it was a question of civilising the Indians, to make them "good citizens" (Ciccarone 
2006, pers.comm.; see also "domestication" [integration] of indigenous peoples, Saugestad 2001:103.). A few years later the Indians managed to leave the reserve and return to Aracruz Municipality, which had now been mostly deforested by Aracruz Celulose.

In addition, the Tupinikim said that FUNAI had also previously negotiated with Aracruz to move them to the Indian Reserve located as far away as Amazonia, including "a deal concerning some kind of land exchange". As the elders heard about it, they fled and hid in the remaining forests in order to avoid the possible forced migration. The Guarani cacique has criticised FUNAI's role and the overall land rights problems of the Brazilian indigenous peoples:

I have tried to ask as to why FUNAI let the company arrive here in the first place, but I have never received any answer. This is always the case wherever the Indian villages exist: they are given farewell from the area and nobody knows what happens next.

In 1978, Aracruz began to operate its first plant that was situated next to the one of neighbouring Tupinikim aldeias. A small group of the Tupinikim and Guarani resisted in an area of a mere 40 ha. Despite the fact that in 1979 FUNAI basically designated three areas totalling 6,500 ha for them, in 1980 the Indians started to demarcate the lands themselves due to delays on the part of FUNAI. The incident led to violence by the police. Aracruz demanded a new proposal by pressuring the state government, and this ended in an agreement with FUNAI. It implied that the designated areas were reduced to 4492 ha, demarcated in 1983, and officially registered in 1988. Thus, the Indians and Aracruz made an initial contract to settle the land dispute.

The process of land demarcation, including ambiguous legal procedures and decisions, has continued to be complex up today. Despite FUNAI's responsibility to organise administrative procedures for the demarcation of indigenous lands, we can notice that its role both in Espírito Santo and also Bahia has been rather contradictory. The registration of indigenous territories has been very slow, and also hindered by the pulp companies. Article 231 in the Federal Constitution recognises the native rights of the Indians to their traditionally occupied territories. (Executive Commission of the Tupinikim and Guarani 1996: 27). In the identification phase, the Working Group appointed by FUNAI collects the proof of traditional indigenous occupation through various multidisciplinary studies in the region. In the contestation phase, interested parties may present their contestation with proofs to FUNAI on the possession of the land. Declaration implies that the Minister of Justice will declare the boundaries of the indigenous area and establish its demarcation (also the identification may be rejected on the basis of noncompliance with the Federal 
Constitution). In the administrative phase, FUNAI demarcates the land boundaries by placing official landmarks on the boundaries, which have been indicated in the edict of the Minister of Justice. (Executive Commission of the Tupinikim and Guarani 1996: 27-28.)

During the 1990s, the Indians continued their land claims, supported by national and international campaigns, run by NGOs. FUNAI formed a new Working Group to re-examine the boundaries of the indigenous areas of the Tupinikim and Guarani, and as a result of the first study in 1994, their indigenous area was identified as 13579 ha. However, according to the Indians, FUNAI pressured the caciques to travel to Brasília, to the Ministry of Justice, in order to sign a new contract with Aracruz. The agreement included 10 million USD, implying that they would accept a considerable smaller area, only 2571 ha. The company was to pay the sum within 20 years, as well as to rejuvenate the polluted local river and carry out reforestation. As the caciques were still reluctant to value their land, they were pressured and mislead by the authorities, as they claimed. Afterwards the caciques have regretted that they agreed to sign the paper and its contents, which they did not fully understand. In order to make a stronger alliance in the "land fight" (luta pela terra), they established an organisation, Associação Indigena Tupiniquim e Guarani (AITG) and a Commission, which ever since have articulated their own interests when campaigning against the company.

FUNAI continued to carry out two more official studies up till 1998, and the indigenous area was identified as 18070 ha. It was recommended that it should be registered in order to guarantee the physical and cultural existence of the Indians. As the area was confirmed by FUNAI, but the land demarcation was delayed, the Indians decided to start a second self-demarcation in 1998, and this was ended once again by the Federal Police who suffocated the uprising with violence and temporarily isolated the aldeias. The Minister of Justice (at the time) acknowledged FUNAI's studies, but still confirmed only an area of 7,061 ha to be registered and the remaining 11,009 ha were left without recognition - this area was to become a major cause of future disputes with the company. (Photo 1.) 


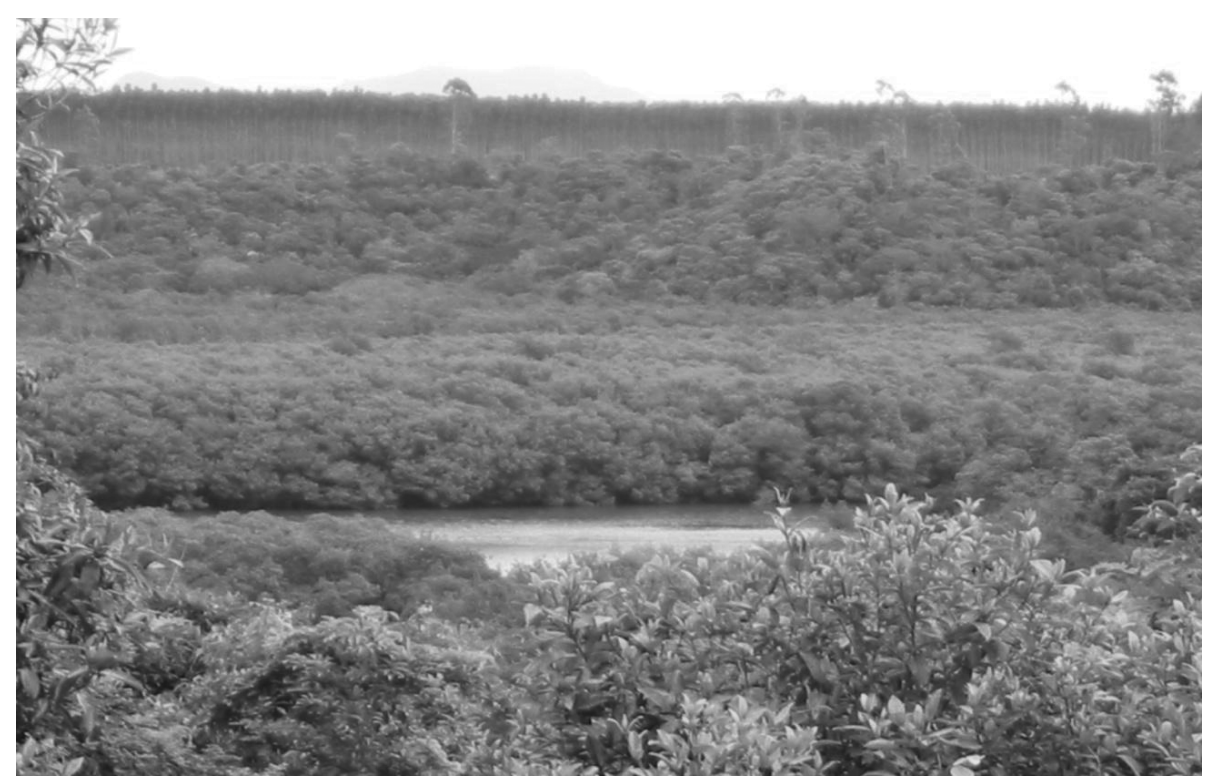

Photo 1. Eucalyptus plantation meets Atlantic Forest. Photo: Susanna Myllylä.

\section{The Tupinikim: a turn from subsistence farming to plantation economy ${ }^{9}$}

According to FUNAI's census, the Indian population was 2,765 in 2004: 2,552 Tupinikims and 213 Guaranis live in their aldeias in the Aracruz Municipality (Barcellos and Ferreira, 2007, $14^{10}$ ). The current Tupinikim aldeias are Caieira Velha, Comboios, Irajá and Pau-Brasil, which are not tightly bordering each other, but rather left in "pockets" between plantations. (Photo 2.).

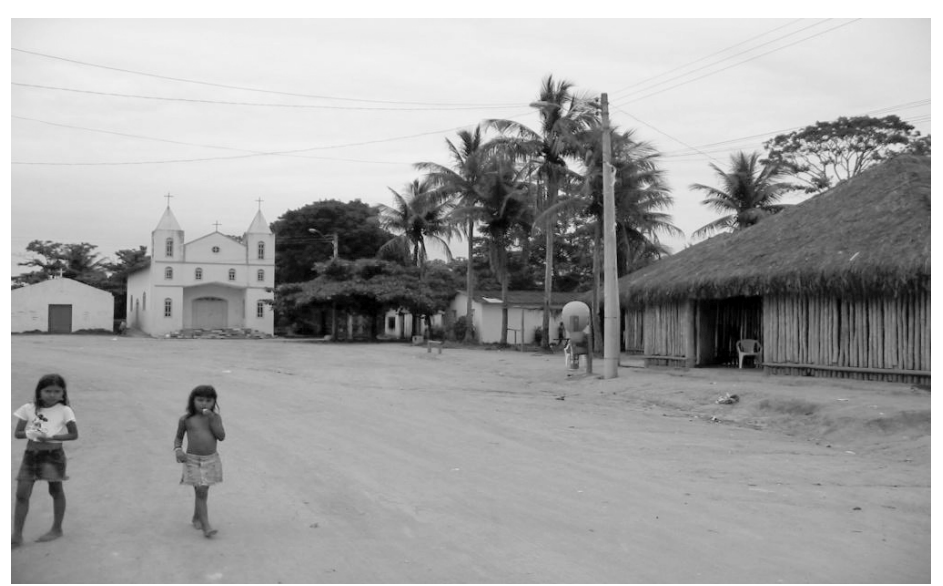

Photo 2: Tupinikim aldeia Caieira Velha, affected by Catholicism. The Catholic Church, according to the Tupinikim, was the only actor who supported them in the early years of the land dispute. Photo: Susanna Myllylä.

\footnotetext{
${ }^{9}$ This chapter is mainly based on the group discussions with the Tupinikim.

${ }^{10}$ In 2006, the Tupinikim population was 1.950 (Funasa, in Instituto Socioambietal 2009).
} 
The Aracruz's impact on the livelihoods of the Tupinikim has been fundamental and manifold. Most of the marshes and mangroves have gone because eucalyptus plantations have drained the land. Due to deforestation, as well as soil and water pollution, wildlife resources have also become depleted in the area. The Ibama environmental authority ${ }^{12}$ has prohibited the Tupinikim from collecting materials for their traditional activities or killing animals for food. Previously they used to live in abundance:

We did not have difficulties hunting wildlife, such as armadillos, antelopes, pigeons, and also sloths, which we would love to eat. Jaguar, which was also common here, we did not hunt for food, but because we were afraid of it. Our caciques used parrot and jacu feathers for headdresses, now they have to mainly use coloured chicken feathers instead.

Lianas and bark from trees (such as imbira) were used for women's wear, handcrafts and domestic utensils (like samburá baskets for fishing). Whenever Ibama has found the Tupinikim snaring fish, crabs and oysters in the nearby rivers during the breeding season, it has confiscated their catch and devices. The Tupinikim have observed that before hunting and fishing were not a problem, but after the arrival of Aracruz, the wildlife population has collapsed, and suddenly their traditional lifestyle has come under the scrutiny of Ibama. (Photo 3.)

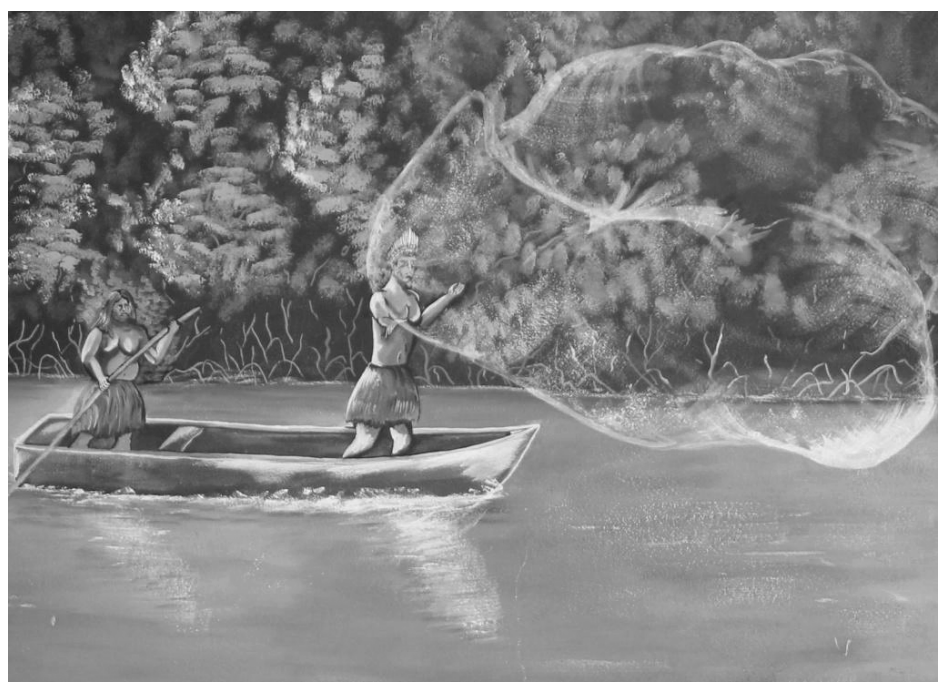

Photo 3: The livelihood of the Tupinikim in the past. Photo: Susanna Myllylä.

\footnotetext{
${ }^{12}$ Instituto Brasileiro do Meio Ambiente e dos Recursos Naturais Renováveis.
} 
The Tupinikim cultivate coffee, beans, coconut and cassava, but not every family possess their own fields. Coffee has been their main source of income: "if we do not have pire pire (money) we cannot purchase things". They would also like to plant corn, but the soil is too exhausted and polluted, so they should first purchase fertilizers - "for a place that was previously soil-rich rainforest".

From the 1990s, Aracruz Celulose started to approach the Tupinikim and the Guarani with social projects, offering some medical services and education, for instance. In this "socio-environmental game between the actors" (Andrade 2007; see also Aracruz Celulose 2006), modern commodities were given, such as mobile phones and bicycles. The critics have argued that the company just aims to use social control tactics over the indigenous groups, which, in the long term, will not suffice as long as the land dispute remains unsolved. (Myllylä 2007.) In addition, the critics also claim that in order to apply for the FSC certification label, the company's strategy has been to generate social projects.

The main income for the Tupinikim has come from selling coffee outside - but they also started to grow eucalyptus for Aracruz in 1999. How did they end up at this point in the first place? Due to ever decreasing options for daily subsistence, they decided to join the Aracruz's Social Forestry Program. Aracruz donated the seedlings and fertilizers to the community and they started to plant eucalyptus in their territory, to be later sold to the company. (Photo 4.)

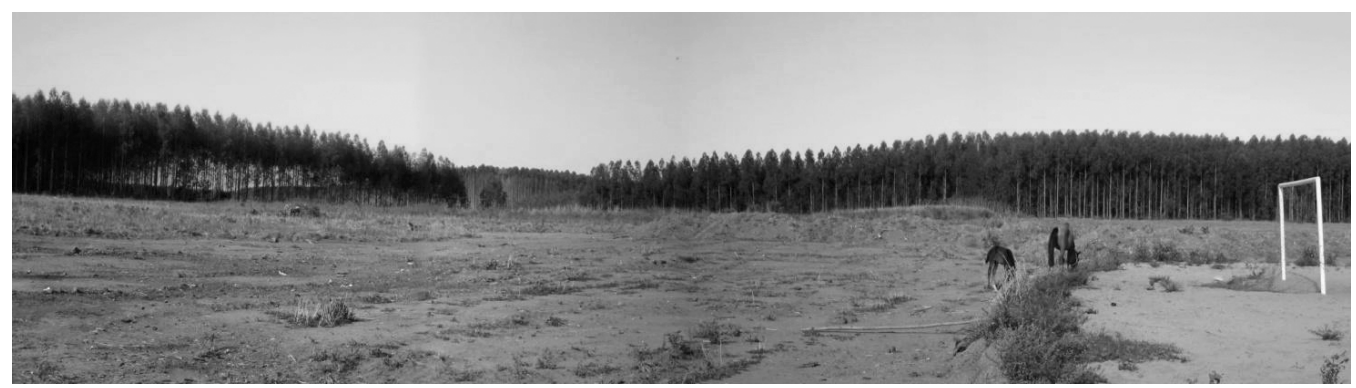

Photo 4. Aracruz's Social Forestry Program on Tupinikim land. Photo: Susanna Myllylä.

However, due to the seasonal nature of this new livelihood, the majority of the young adults were unemployed. Despite the fact that just few of them worked in the Aracruz's factory, the company was accused of saying they employed more Indians than they actually did. Also the company "banned them from speaking Tupí, as the early colonialists did their ancestors". The language gradually vanished among the tribe in the region. It was also said that in the beginning of this 
century, in the Espírito Santo community, there was only one person, a young man (currently one of the activists in their association with the Guarani), who "learned back the language, taught by a helpful university professor". The Tupinikim use both Portuguese and Tupí personal names. The company's social program serves an illuminating case of governance and guided inclusion in regard to indigenous communities.

By the end of 2004, the Indians had not given up their land claim and hence the "Aracruz management did not want to communicate with them anymore". The Tupinikim also stopped participating in the company's Social Forestry Program. Instead, they kept clinging to the hope of reforesting the Mata Atlântica, but said that they lacked a suitable partner to do it. It seemed that sustaining this positive, if not romantic, vision and already planning future operations - as much as it seemed to be an impossible endeavour, not only due to land dispute but also ecological constraints - was the whole basis behind the land struggle. The Tupinikim appeared to be very sure of getting back their territory as a whole and rebuilding their livelihood as well as identity.

\section{The Guarani and the quest for a Land Without Evil}

The Guarani $\left(\right.$ Mbyá $\left.^{13}\right)$ aldeias are Boa Esperança, Três Palmeiras and Piraquê-açu. The Guarani prefer to keep their own basic cultural traditions - religion (or worldview), subsistence farming, education, and language (Mbyá Guaraní) including names - isolated from the impact of Brazilian society. (Photo 5.) However, as elsewhere, they have accepted some modern amenities, like mobile phones.

\footnotetext{
${ }^{13}$ The Guarani in Brazil are divided into three groups: Kaiowá, Ñandeva and Mbyá.
} 


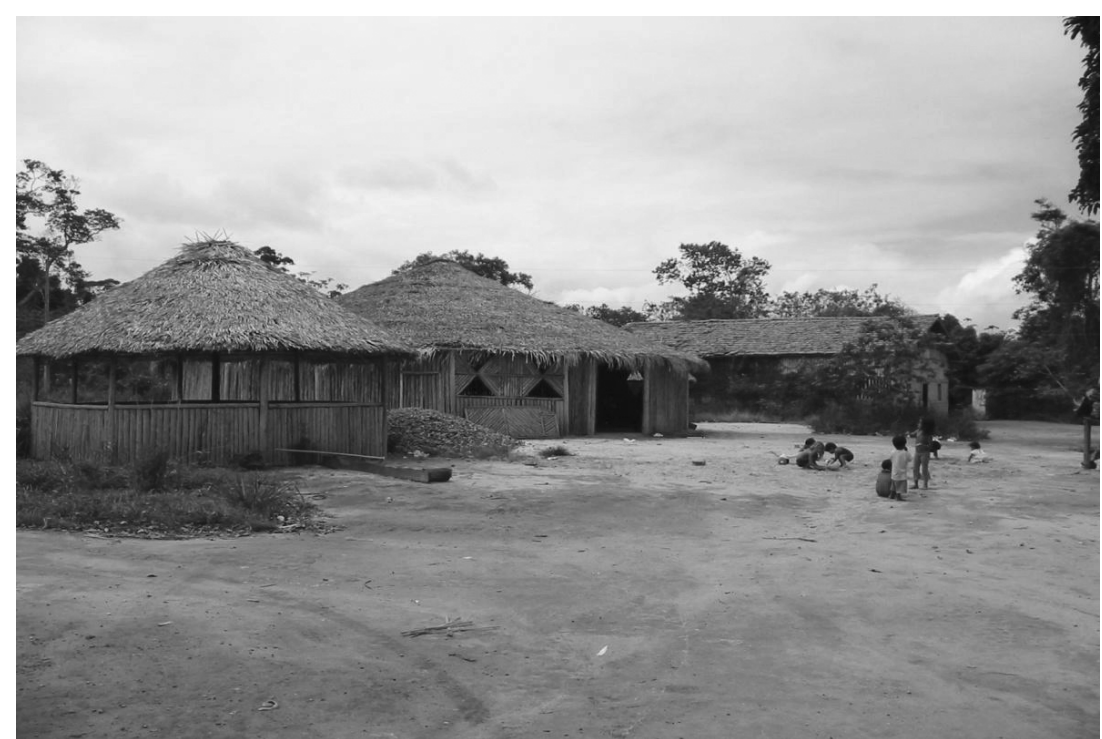

Photo 5: Guarani aldeia Boa Esperança in November 2004. In December 2006, only one of these houses remained. Photo: Susanna Myllylä.

The surroundings of the three aldeias include some natural forest. The Guarani consider themselves forest protectors and they did not want to become part of the Aracruz's Social Forestry Program like the Tupinikim. For the Guarani, the eucalyptus species are without any nutritional importance for the people, nor do they produce seeds for animals. Their livelihood is based on forest gardens. Between the trees are grown among others; cassava, coffee and banana, as well as medicinal plants, of which their healer knows over 70 different species. In order to get milk and other food products they do not have, they sell coffee and crafts for the tourist trade. The Guarani rarely consume meat as the animals they catch from the forest are strictly regulated by their religious practices.

Also, the elder Guarani remember the time before the company, as the area was covered by rainforests, mangroves and swamps, and it was common to see alligators in the nearby river. They claim that Aracruz plantations have dried up the soil and because of the lack of buffer zones and agrochemicals spill into rivers when it rains. However, the Indians take drinking water from these rivers. Like the Tupinikim, they have also found unusually high numbers of dead animals, such as birds, small antelopes and armadillos. According to the healer, after the "non-Indians" (Aracruz) arrived, and simultaneously contributed to the "rush of other Whites" onto indigenous land, air pollution has made respiratory illnesses and severe headaches common among the Indians, as well as "new diseases" like cancer. In addition, alcohol has become a new problem for the community. Previously, Aracruz's doctors visited the villages within the social program, but this was not 
enough to cure the people's diseases. (Photo 6.) The Guarani also criticise the State administration, which has given its full support to Aracruz.

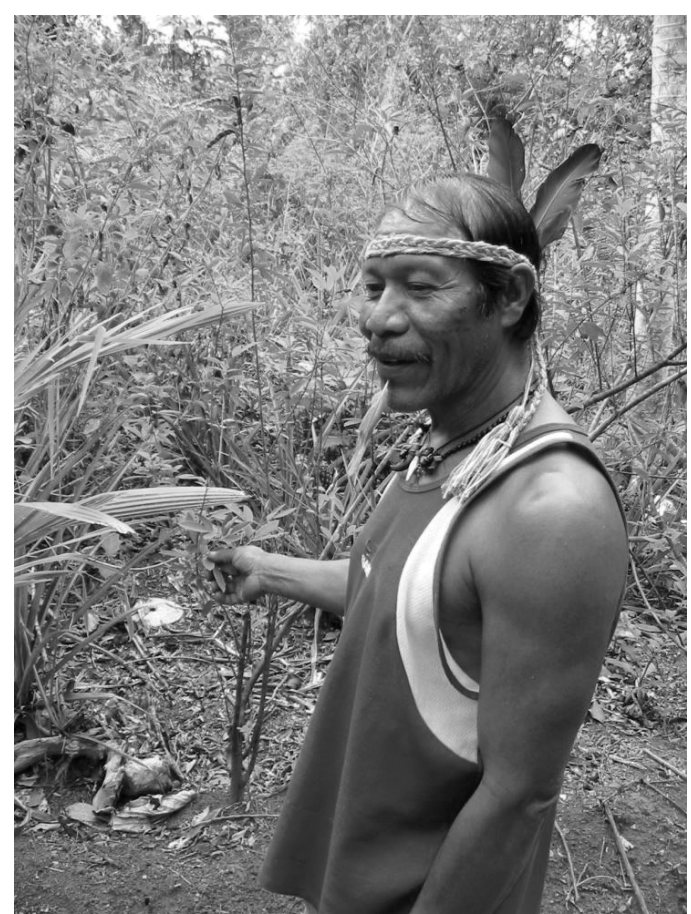

Photo 6. Guarani healer, vice cacique Tupã-Kwaraÿ knows how to use the feijão-guandu bean for food and tea, but also as a medicine to cure some respiratory illnesses. However, the tribe has problems coping with the new respiratory diseases caused by Aracruz, as the community members perceive the issue. Photo: Susanna Myllylä.

Compared to the official political and geographical definitions of regions ${ }^{15}$, the territorial perception of the Guarani is different or a much wider concept, as one cacique explained:

In Brazil, our territory reaches to Pará (in the North coast). Paraguay is our centre of the world.

The Guarani dominion over a large territory takes place through social, economic and political dynamics (see Ladeira 2001). It explains why numerous Guarani groups move between Brazil and Paraguay, from where they originated, and constantly construct and deconstruct their aldeias in various places. However, the Guarani are not nomads, as they are often called (Ciccarone 2006, pers.comm.; cf. Clastres 1995: xi). In this Atlantic coastal region, which has become the most

\footnotetext{
${ }^{15}$ The "obsession of modernity" can be discussed here concerning the concept of territory: it can be seen as a narrative or imagination, physically and materially constituted. The Guarani define their world according to both material and symbolical meanings (see Ladeira 2001: 13-14).
} 
industrialised and urbanised domain in the country since colonialism, the Guarani still "navigate" according to their cosmology, searching for suitable living places, and the ultimate aldeia; "The Land without Evil" (terra sem mal). This refers to a place that is located outside of the dominant society and its rules. According to Maria Inês Ladeira (2003; see also 2001, 2007; Ribeiro 1992): "...their mythical precepts that are at the foundation especially of their relation with the Atlantic Forest, on which, symbolically or practically, they condition their survival. Establishing villages in these 'chosen' places, including flora and fauna typical of the Atlantic Forest, means being closer to the celestial world, since it is from these places that access to yvy marãey, 'Land without Evil', is made easier."

According to Hélène Clastres (1995: 54), it is a question of the active denial of society and the search for the "Other" which forces the Guarani to remain isolated from the influences of Brazilian society. Their migration could also be interpreted as manifesting community empowerment (Ciccarone 2006, pers.comm.). The most powerful Guarani leaders are found among women, passing this position via the blood-line (see more in Ciccarone 2004). According to Kretsu Miri (deceased in 2005), a shaman's prophecy gives the wider Guarani community information about where to move to next. This usually happens every 6-8 years. She had already received a divine vision of a "holy mountain" situated in the north, to where part of the community should move to establish a new aldeia. As when the Guarani first arrived in the Aracruz Municipality, this place would also have been covered with Atlantic Forest, which seems an embedded feature in the visions. Furthermore, the Guarani healer defines the metaphor terra sem mal as follows:

It is a place without sorrow and bad things. There one can live in peace and outsiders do not disturb us. It is a place, where there is no violence, and no Aracruz.

Interestingly, Aracruz's presence and the land dispute had encroached here in an old cosmological definition. This may reflect a cultural change in their religious discourse as a response to the modernisation of society. As "traditional" or local knowledge constantly changes as an everevolving syncretistic process (see Pottier 2003: 1-2), due to competing definitions and external influences, also the arrival of modern industries in the neighbouring areas has affected the terminology of the Guarani. For instance, eucalyptus has been named as the "tree without a soul" (árvore sem alma) or a "poison tree" (árvore tóxico). Petrobras, the biggest Brazilian energy company, planned to build a gas pipeline across the indigenous territory in the $1980 \mathrm{~s}$ - which also would have had a positive result for Aracruz - when the land dispute would have ceased 
concurrently. The researchers at $\operatorname{UFES}^{17}$ made a study according to which the pipeline was relocated to the border of the indigenous territory. The Guarani started to call the pipeline a "fire road" (caminho de fogo), and fire is an apocalyptic metaphor for the Guarani. (Ciccarone 2006, pers.comm.; see also Ribeiro 1992). (Photos 7 and 8.)

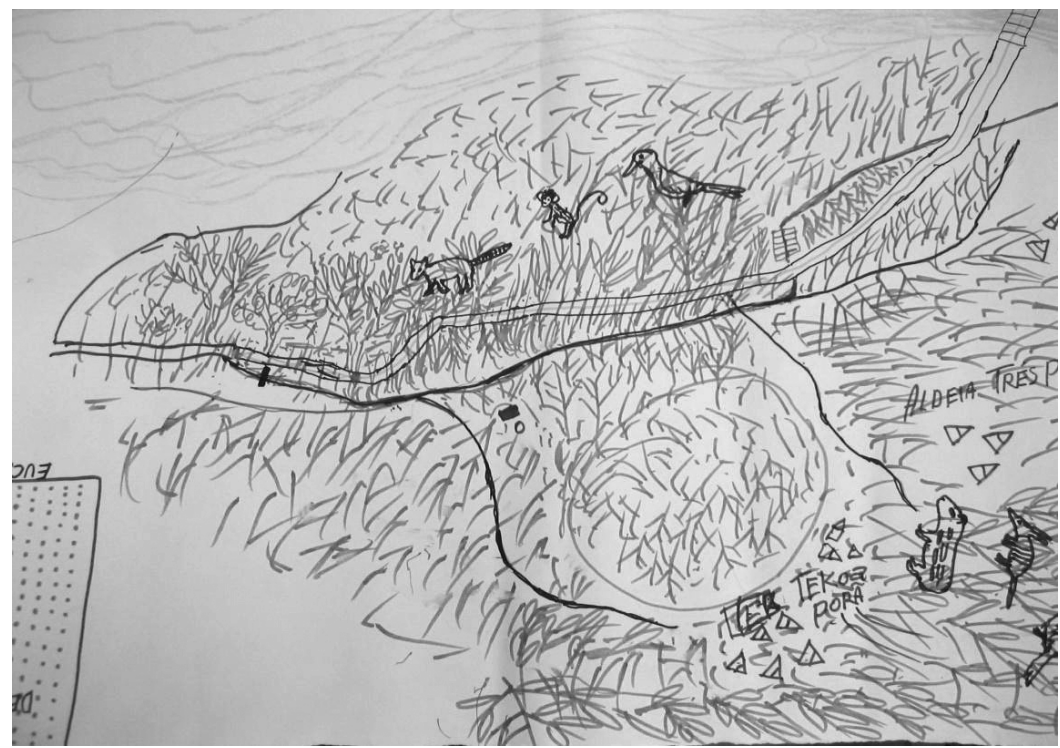

Photo 7. Environment of Tekoa porã (aldeia Boa Esperança) and the neighbouring two Guarani indigenous areas drawn by the healer Tupã-Kwarä̈. Aracruz plantations are located to the left corner. Photo: Susanna Myllylä.

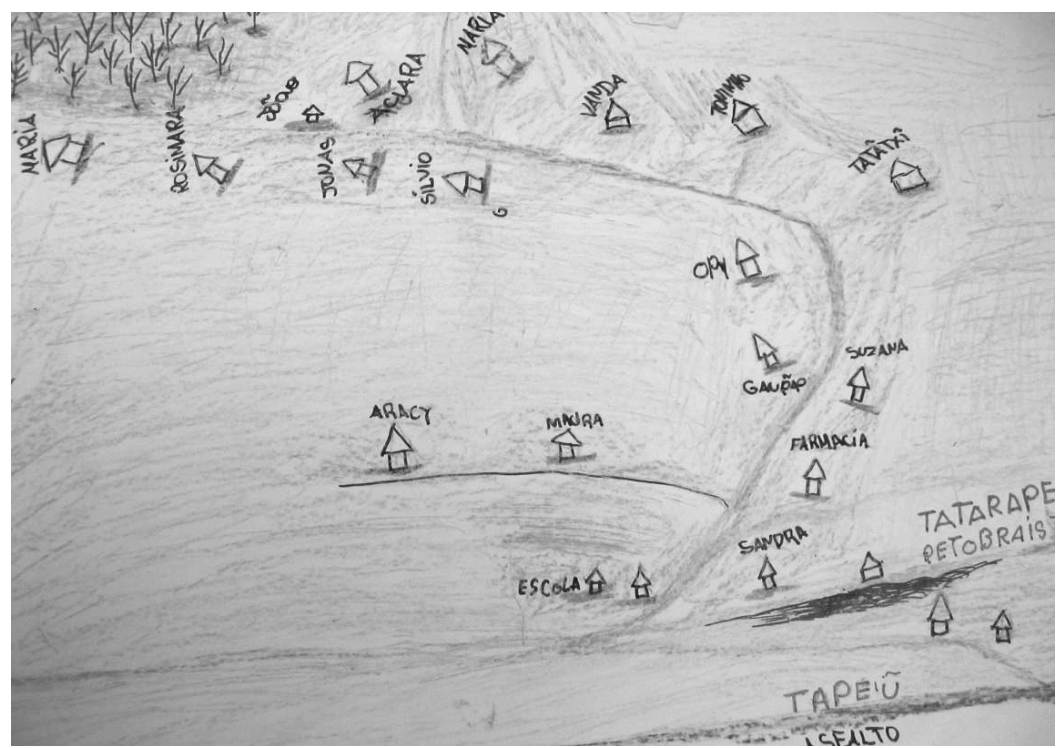

Photo 8. The village map of Tekoa porã (aldeia Boa Esperança) indicating the location of families and a few services (school, pharmacy) by Joana Tatãtxĩ Ywa Rete. Coffee plants begin the way to the gardens in the upper left. Local road (Tape'ũ) and Petrobras pipe (Tatarape) are also shown. Photo: Susanna Myllylä.

${ }^{17}$ Universidade Federal do Espirito Santo. 
Moreover, the Guarani knowledge system is heavily based on non-verbal expressions, like singing, which is a central element in sacred shamanic traditions ("the beautiful language" Ayvu porä, "common to gods and human beings", see Clastres 1995: 73-75). It has been questioned that language is a sufficient tool for accessing knowledge. The knowledge production of indigenous peoples often includes improvisation and creativity (Pottier, 2003: 7). In all, it would be interesting to study more, how modern industrial production affects the Guarani worldview and practices. The Guarani cacique described Aracruz's impact on their mobility:

Before Aracruz, all Indians were free to move along the coast. When the company arrived and started to destroy the Indian cultures, they left. Now if Indians try to return, the company calls it an

"invasion". These pulp companies conduct development towards the progression of death. There are many ways to kill a culture, like the company destroys our livelihood.

\section{The myth-oriented and malevolent corporate tactics}

Being not fully supported by the Ministry of Justice on several occasions, and receiving contradictory actions at the hands of FUNAI, it was not until in 2005 that the Indians' claims were taken into account. The Minister of the Interior proclaimed the contract between Aracruz and the Indians illegal, and recommended the new Minister of Justice announce the entire 18,070 ha as indigenous land, including the remaining 11,009, which had been left out of the deal in 1998 and was still in the hands of the multinational company.

In 2005, frustrated at waiting for the court decisions to be implemented, and disappointed at the inefficiency of FUNAI, the Indians decided to carry out a new demarcation of their own by cutting down eucalyptus to define the boundaries of their area. They also rebuilt two old Tupinikim villages, which was "also 'reconstructing' their way of life with traditional housing and traditional subsistence crops" (CIMI 2006). In early 2006, the situation escalated into outright conflict when Aracruz's interests were supported by the arrival of the Federal Police, who destroyed the two rebuilt villages and injured several Indians by shooting them with rubber bullets from helicopters. The company made a statement about this incident on its internet homepage, but with no mention of its own unethical actions. Furthermore, according to its corporate Code of Conduct, the company is committed to various good governance principles, including respecting human rights of the indigenous peoples.

The Indians reported that more than the physical damage; the emotional and spiritual injuries 
remained after the incident, evoking collective memories of the violence in 1967. In their campaign material the wounded leaders were photographed and under the photos were written: "Today we have been humiliated ... in the $21^{\text {st }}$ century, we are hunted like animals". Despite the fact that these clashes resembled a kind of a "David and Goliath" situation - from an outsider's viewpoint - the Indians continued their resistance movement and soon organised another demonstration, indicating their resilience in the land struggle (Photo 9.).

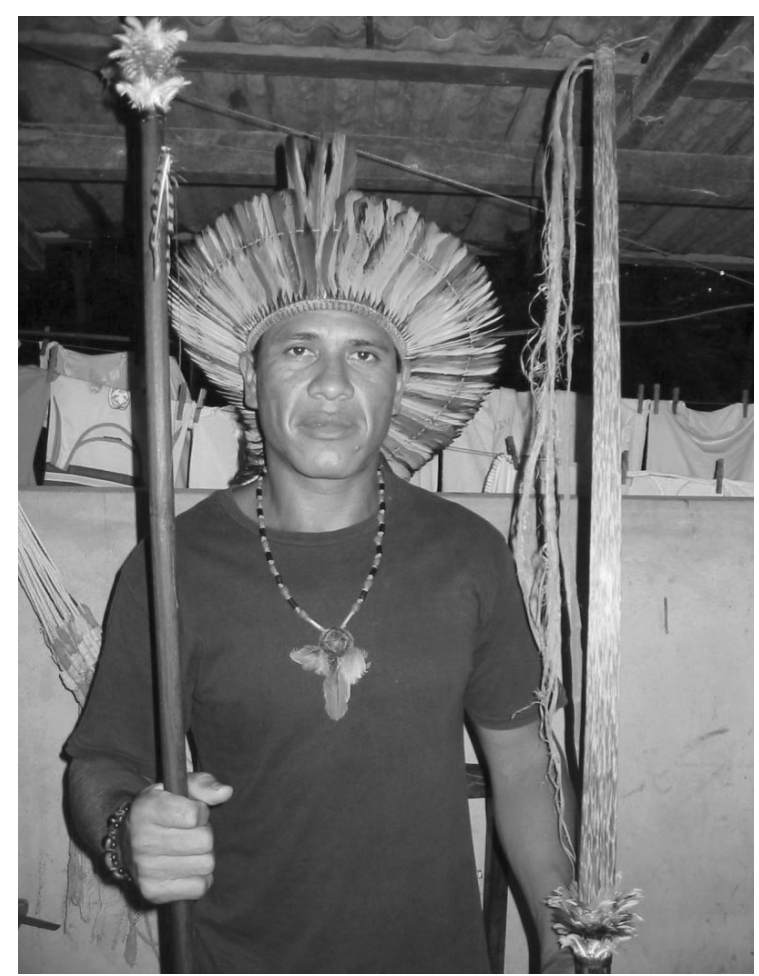

Photo 9. The young Tupinikim cacique Wilson Jaguaretê is going to be one of the leaders in the forthcoming resistance movement in December 2006, for which he is preparing at home some traditional wooden weaponry to confront again Aracruz security forces. Photo: Susanna Myllylä.

In September 2006, a wide-scale campaign started in Aracruz town, targeting the Indians in the land dispute issue. The campaign included wide media coverage, demonstrations, street signs, school materials, booklets, Aracruz web pages, PowerPoint presentations (targeted at the company's business partners) and other measures. However, this campaign was not in the company's own name, but it was considered obvious that Aracruz had financed this level of campaign. Large billboards, with the logos of Aracruz company partners, were situated along the roadsides. (Myllylä 2007.) The campaign presented the company as an important actor that has brought economic wealth to the inhabitants, whilst the Indians were insinuated as being less meaningful, if not even an obstacle to the region's development: 
Aracruz brought the progress, FUNAI the Indians (Aracruz trouxe o progresso, a Funai, os índios.)

Also, the campaign presented the idea that the company was the victim, and the Indians were blamed for harassing Aracruz workers:

Enough, Indians, bullying the workers (Basta de indios, ameaçando trabalhadores.)

This referred to situations where the Indians arranged various types of protests; occupying corporate spaces, street demonstrations, etc., and these included hundreds of participants. They also represented members from other Indian tribes and NGO activists. Other NSMs that resisted monocultures expressed solidarity with, for instance, was the Movement of Small Farmers. In the campaign rhetoric, the Indians addressed their peaceful aims despite the company campaign attempting to present the opposite message. The situation escalated to physical conflict as the company's security forces, workers and the Federal Police turned to violence to remove the protestors who had occupied sites owned by the company. To cite an example, the workers at Plantar, a partner firm of Aracruz, started to remove the Indians using heavy force, because they had occupied the Aracruz harbour.

According to the indigenous social movement rhetoric, particularly expressed by the supporting NGOs, as well as by some researchers, the company's campaign was based on a racist $t^{20}$ approach: the company used all possible means to win the land dispute and attempted to interfere with the cultural identities of the Tupinikim and the Guarani. The main campaign argument was that neither of the indigenous groups had title to the land as though they were only "alleged Indians", culturally degraded (the Tupinikim), or, originating from elsewhere (the Guarani). (Movimento 2006a, 2006b; UFES 2006 $6^{22}$; Myllylä, 2007.) Thus, the company decided to rely on another type of rough tactic by spreading disinformation about the indigenous groups, and targeting Brazilian society to achieve acceptance of their actions in the land dispute. While the company tried hard to deny the history and existence of indigenous communities in the region, the caciques from both tribes were astonished to hear this because the company had made various agreements with their Indigenous Commission per se. In the campaign material some satellite images were also used to indicate that indigenous villages did not originally exist in the area that was contested.

It is obvious that "quasi-scientific" research was used in the campaign, namely a report written by

\footnotetext{
${ }^{20}$ Concerning "ethno-racism" towards indigenous peoples in Aracruz Municipality and discrimination at the State level, see Lopes 2008; Cota 2008.

${ }^{22}$ Research group discussion, Universidade Federal do Espirito Santo, Vitória.
} 
a number of anthropologists hired by Aracruz for the company's appeal in response to the federal court decision to widen the area of indigenous land. The report was also distributed to Aracruz's partners in order to gain support for the company's interests. The purpose of the report was seemingly to devalue the contemporary Tupinikim community and culture as unauthentic by invoking the colonial impact, their caboclo (mixed Indian-white) background, and also referring to modern lifestyles, as many Tupinikim live in brick houses and some possess satellite dishes, which are typical of Brazilians in general. The cacique Wilson Jaguaretê, whose entire Tupinikim identity - from his name to his headdress and skin painting - was deconstructed: it was claimed that all his cultural features were false or copied from other tribes, in order to illustrate the assertion of "alleged Indians". The cacique challenged the report written by anonymous experts, and referred to the collective memories held by the elders as more valid knowledge:

Who were these 16 anthropologists and where have these studies been published since we have not seen them? The memories of our elders, what happened in the past, are more important.

Thus, the company's campaign arguments as to how the "real" Indians should not live and express themselves, represent an imaginary and myth-driven viewpoint that is discussed particularly in the postcolonial indigenous peoples' studies (cf. Tuhiwai Smith 1999²3). Sidsel Saugestad (2001: 64$65)$ points out that when contrasting various cultures, indigenous peoples have been defined through dominant negations and generalised characteristics; for example, in the case of the Bushmen, presenting them as the people of the past, or defining them by the absence of valued qualities from the dominant culture (lack of resources, living outside towns etc.). However, he also argues that indigenous peoples want to participate in development, but on their own terms, and not to reject development. A living culture's chance to survive and develop itself depends on its ability to control the introduction of modern elements, such as new technologies, and not to turn them down (p. 64). As Veli-Pekka Lehtola (1999) also analyses certain stereotypical images about the Saami people, he concludes that remaining in a static cultural state as "authentic Saami" would have led to cultural atrophy for the Saami people. On the contrary, an awareness of their own culture's vitality has enabled the open-minded assimilation of new influences, and thus a cultural upheaval. So according to Aracruz campaign rhetoric, representing a kind of museum approach, the Indian cultures should remain unchanged and without connections to Brazilian society. This is also related to the "ethnic purity" approach (Silva 2006, pers.comm).

\footnotetext{
${ }^{23}$ Linda Tuhiwai Smith rejects "post-colonialism" as she considers that colonialism continues to have comprehensive impact on indigenous peoples.
} 
The Guarani cacique described their view of the campaign, comparing it to the ostracized position of the indigenous peoples of Brazil:

We have already suffered that our reputation is spoiled in general. Now we are referred to as something that we are not: attempts are being made to take our identity away and simultaneously, the land struggle is twisted. The Aracruz president himself has claimed that the State area has never been inhabited by Indians, even though already at the beginning of the $18^{\text {th }}$ century, the Tupi-Guaranis lived here. By denying the existence of the Indians the company tries to close its eyes on our presence.

Aracruz's workers and over 300 partner companies - including the Finnish Metso Corporation, which supplies Aracruz and Veracel with pulping technology - became involved in the campaign because these company logos were included on the roadside signs. According to the Metso management, they did not know about the campaign and hence their logo was used illegally (Seppälä 2008, pers.comm.). Local researchers claimed that Aracruz employees were pressured into participating in the street campaigns in order to keep their jobs. Furthermore, according to several Brazilian civil society organisations, their staff and activists, who supported the Indians in various protests, were intimidated by the company in various ways. (Myllylä 2007.)

At the end of December 2006, the Federal Court condemned Aracruz Celulose for racism and discrimination against the Tupinikim and the Guarani as indigenous peoples, and Aracruz were taken to court. The company was obliged to withdraw its racist information. Later on in August 2007, Brazil's Minister of Justice signed an administrative ruling declaring the entire area claimed by the Indians as indigenous land (18 $070 \mathrm{ha}$ ). This resolution changed the direction of the longterm land dispute. It remains to be seen how the situation between the Indians and the company will develop in the near future.

\section{The Pataxó: divided due to social programs?}

In the state of Bahia, the Pataxó Indigenous Reservation was officially registered in 1861 as an Indian settlement, although the Pataxó have been living in the area long before the colonial period. The principal settlement of the reservation is aldeia Barra Velha, located on the coast of Porto Seguro. It is divided into several smaller recognised regional sub-units or sub-villages. According to the 2005 official census, Barra Velha's population was 1082 people (Sociedade Nordestina de Ecologia 2001: 58). As it is legally registered, some others, such as Guaxuma, still claim demarcation and legalisation. The relations between the Pataxó and Veracel Celulose are diverse 
since the company has only recognised three of the 16 Indian villages. Veracel has a rather good relationship with Barra Velha while there is no dialogue with the Guaxuma community.

According to the Instituto Observatório Social report (2005: 39-42) Barra Velha villagers have mentioned several positive initiatives and social programs by the company, namely the preservation of the environment, the prevention and control of (forest) fires, preservation and recuperation of rivers and some donations to the community. Among the negative aspects identified, a reduction in the number of jobs and the toxic contamination of environmental resources were mentioned. In my research in Guaxuma, water pollution and the death of fish were observed by the villagers.

Aldeia Guaxuma keeps claiming the right to demarcate the land, for which they have been waiting for around 10 years, living on insufficient land of 240 ha for 28 families (150 people). This area of land was degraded by the former occupant, the wealthier landowner (fazendeiro), and there is no natural forest left. The community's livelihood is precarious, coming from subsistence farming and crafts for tourism. (Photo 10.)

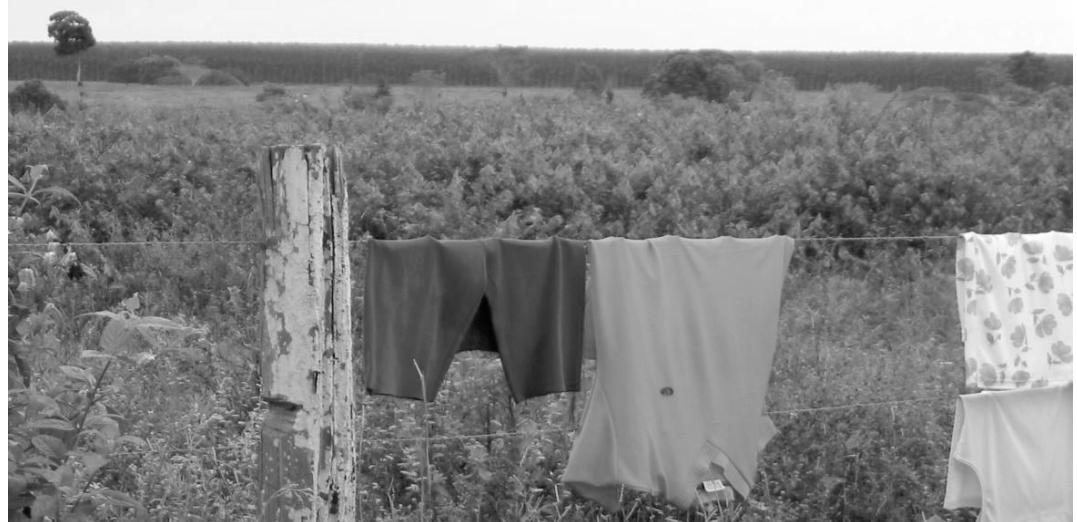

Photo 10: Guaxuma in a poverty pocket. It is a rather striking view that a eucalyptus field surrounds the village on every horizon - one member described it as an "approaching tsunami". Photo: Susanna Myllylä.

In 2004, in an attempt to grab the attention of the authorities regarding the Guaxuma community's land claim, they decided to organise a demonstration obstructing federal highway BR-101. They set fire to a lorry holding Veracel eucalyptus and kept some public officials captive. According to the Pataxó, Veracel was the demonstration's target because it had planted eucalyptus on a property it was aware within the boundaries of the area being claimed. The Indians stated they have no interest in a dialog with the company, and that all they want is recognition, legalisation and respect for their 
land. Veracel, in turn, argued it had only bought the properties after verifying there was no conflict or litigation between the 41 proprietors and Indians, and that until that moment the authorities had not concluded studies to define if such a tract is traditional Indian land. (Instituto Observatório Social 2005: 40-41.)

It seems that Veracel itself has not been explicitly involved in violent confrontations as in the case of Aracruz in Espírito Santo; rather the fazendeiros have forcefully evicted Indians from their villages to prepare land sales to Veracel. This is indicative of how complex the phenomenon of agribusiness is and that it entails numerous actors. Some Pataxó leaders argue that when the company tries to persuade them to support its production by offering money, it is just a corporate strategy to expand the area used for eucalyptus. The different relationships with the villages raise the question of possible negative impacts for internal cohesion among the Pataxó ${ }^{26}$. The cacique of the Guaxuma states:

When (the President) Lula came to inaugurate Veracel, the company attempted, as always, to present themselves as a friend of the Indians - as if it would have some kind of informal partnership with all the Pataxó. In Barra Velha the company has helped with tree nurseries and given cattle. We in Guaxuma try to keep voice that things are not quite what the media presents. So we took back the area where we started to cut down eucalyptus.

According to Veracel - already two years prior to the completion of the pulp mill in 2005 - the company trained a group of Barra Velha villagers on how to grow native Atlantic Forest tree species:

For three days, members of the tribe learned the techniques that will allow them to establish a nursery in their village for the production of native species. The idea is to produce trees destined for recovering degraded areas on their land, also ensuring the reproduction of species used in their production of handcrafts, the main economic activity of the Indians in the extreme south of Bahia ... Although they live in the Atlantic Forest, the participants in the training program revealed that one of the most important things they were taught was how to recognize the trees when they were still very little. "We only see big trees and never knew how to identify the seedlings. According to Cosme Brás dos Santos (Tixuí Pataxó), the knowledge of the production processes of these types of seedlings will help the Pataxó remain true to their cultural roots. (Veracel News 2003.)

\footnotetext{
${ }^{26}$ The study by Haller et al. (2007) shows that in many instances, the MNCs' strategy is to attempt to divide the indigenous groups: this applied to the majority of the cases they examined (14 out of 18).
} 
This social project would serve as a useful practice for the Pataxó in search of sustainable use of forests, considering that some families use illegally felled hardwood for making crafts to be sold for tourists. On the other hand, it bears some kind of irony when a global monoculture firm, which just started to plant gigantic areas of clone species in the area, teaches indigenous peoples how to sustain biodiversity of natural forests that have been mainly logged by numerous monoculture activities throughout Bahia's history. (Photo 11.)

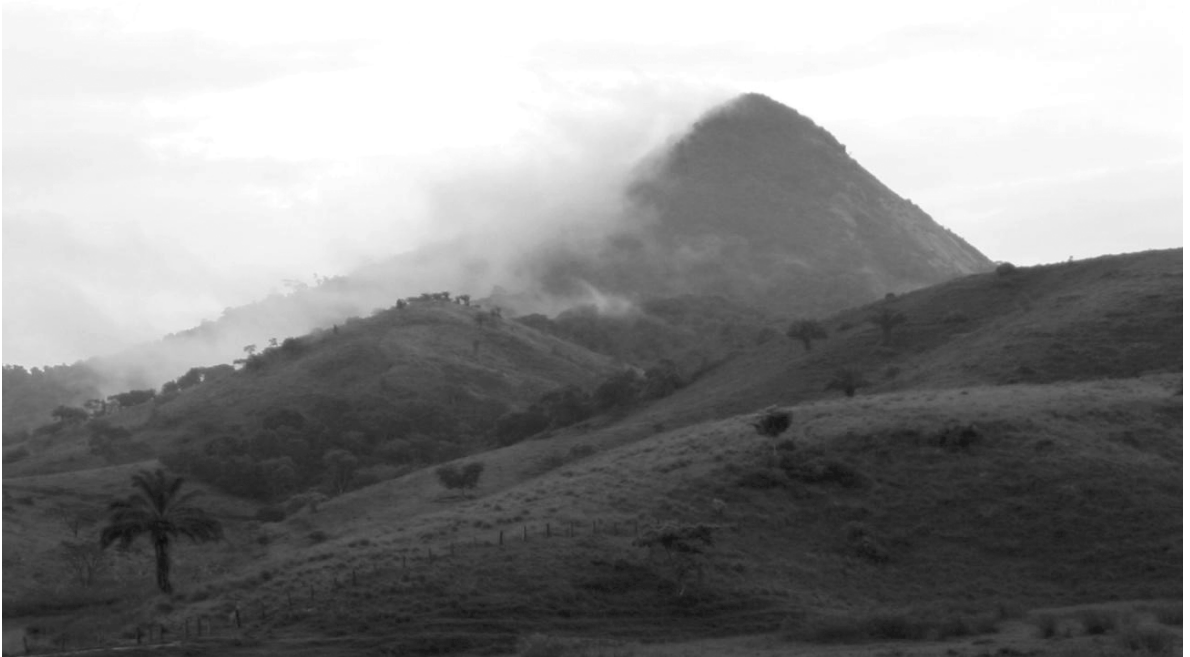

Photo 11. From the road to Monte Pascoal National Park. Colonisation and exploitation of the Atlantic Forest for more than 500 years have taken a heavy toll, and as everywhere along the Atlantic coast, the original forest can be mainly found in isolated patches and steep slopes, conserved due to the difficulty accessing them. Photo: Susanna Myllylä.

\section{Corporate tactics to deny historical facts}

The Pataxó have a minor relationship with Veracel in regard to employment opportunities. Their suggestion to collect plantation waste wood was rejected by the company, as it does not want outsiders to enter its area. Land use diversity in general has diminished in the region, as observed by one Pataxó:

The arrival of eucalyptus has created more poverty. It has not created jobs - nothing. Before, coffee, papaya, and also cattle used to be grown here, all of which created employment. Instead of improving the socioeconomic situation in the region, Veracel, on the contrary, has increased poverty.

Some Pataxós claim that Veracel has illegally planted their traditional lands, and not even the 
discovery of human bones in an area that appeared to be their old cemetery has stopped the company from planting eucalyptus there. Speculations arise as this disrespect or even denial of the historical existence of the Indians in the area represents purposeful strategy by the company:

It has happened at least in one case, but after the company had already bought the land. In front of Meio da Mata village, close to Monte Pascoal Park, was all our ancestral land, and there human bones were found according to my knowledge. Nevertheless, the company started to plant eucalyptus in the area. Then there was another case - a French journalist arrived in our village and saw the negative social impacts caused by Veracel. He travelled to a conference organized by the pulp producers in the United States and exposed what he had seen. Veracel tried to prevent the publishing of the news by announcing that this area did not have Indians when it arrived here.

In addition, the plantations have erased their ancient trails. The above examples resemble the claims by the Tupinikim in Espírito Santo where they accused Aracruz of intentionally purchasing land where their traditional cemetery is located. The Indians considered it part of corporate tactics to destroy existing historical evidence of their presence in the region prior to the arrival of the company.

Veracel aims to achieve national and international acceptance by emphasizing that it is not a rainforest logger, but rather a protector of the region's last natural forests. However, this typical corporate "rainforest protector argument" has been challenged due to several incidents connected to environmental violations, and problems concerning the reception of FSC certification, which also addresses respecting indigenous peoples’ rights. (See Myllylä and Takala 2011.)

In the 1980s, the government granted the Pataxó villages access to 21,000 acres of the national park and kept the remaining 36,000 acres under government control. Since then the federal officials have been talking with tribal leaders about giving the tribe more land, but only if the Pataxó move to another area and relinquish their claims to the park. (Rohter 1999.) More recently, co-management (a gestão compartilhada) of the park has been discussed and suggested by the environmental authorities and FUNAI, however, its contents have remained ambiguous for the Pataxó. Besides, co-management of protected areas is generally an uncommon phenomenon in Brazil. Hence, due to numerous interest parties - the Pataxó, Ibama, Veracel, fazendeiros - the land ownership question in Bahia is very complicated in terms of what may be expected to take place in the near future. According to FUNAI and its research (i.e. identification process) carried out by anthropologists, the entire Monte Pascoal National Park and adjacent areas - including large portions of Veracel's plantations - are to be demarcated as Pataxó territory, which is based on archaeological excavations 
in the study. This news will not be warmly welcomed by other actors, namely the protected areas administration of Ibama and conservationists, nor Veracel Celulose. (Myllylä 2007.)

\section{Conclusions}

It is obvious that in Brazil the government's various policies - that of economic growth, protecting biodiversity and demarking indigenous peoples' lands - collide in many instances. The everexpanding agribusiness of multinational pulp corporations occupy greater land areas, which are often inhabited by indigenous peoples and other rural communities. Their unresolved and ambiguous land ownership question due the bureaucratic, and even sometimes corrupted practices by official institutions lays the basis for land disputes.

In this analysis, I have attempted to discern those multifaceted local situations in which the three communities of indigenous peoples encounter global corporations in the form of land conflicts. The ultimate goal of the companies seems to be a strategy indicating that their adversary does not represent an indigenous group originating from the place in question. The pulp corporations have exerted diverse tactics, from social programs to violent confrontations and the devaluation of indigenous identities in ways that seem imperialistic. Much of these tactics have been aimed at obtaining societal acceptance for corporate interests. Social programs by MNCs often serve as cases of governance and guided inclusion targeted at indigenous communities. The three Indian tribes, in turn, have defended their territories by collective action, as New Social Movements and via their own tactics, such as protests and land occupations in order to achieve publicity and societal acceptance. The land struggles are inherently related to the communities' primary livelihood, the Atlantic Forest. The processes of ethnoterritoriality, due to confrontations with multinational companies, have profoundly affected the identities, social cohesion and even the worldviews of the indigenous communities.

\section{References}

Andrade, C. (2007): "The political-institutional dimension of socio-environmental strategies: the game of Aracruz Celulose SA versus Tupiniquim and Guarani Indians”. In Sharma, S. \& Starik, M. \& Husted, B. (eds.): Organizations and the Sustainability Mosaic: Crafting Long-term Ecological and Societal Solutions. Cheltenham, UK; Northampton, MA: Edward Elgar, pp. 216232.

Aracruz Celulose (2009): "Profile”, May 7, www.aracruz.com (accessed 15.5.2009).

Aracruz Celulose (2007): “Mission, vision and principles”, January 11, 2007, 
http://www.aracruz.com.br/show_arz.do?act=stcNews\&id=328\&lastRoot=106\&menu=false\&lang= 1 (accessed 13.3.2009).

Aracruz Celulose (2006): "Balance of Aracruz's Actions in Support of the Indian Communities", http://www.aracruz.com.br/show_arz.do?act=stcNews\&menu=true\&lastRoot=161\&id=310\&lang= 1 (accessed 11.11.2009)

Aracruz Celulose Annual Report (2005): http://www.aracruz.com/doc/pdf/20f_2005_eng.pdf (accessed 2.5.2009).

Azevedo, T.Z. de (2004): Director, Secretaria de Biodiversidade e Florestas Programa Nacional de Florestas, Ministério do Meio Ambiente. Personal communication, Brasília, Brazil, September 2004.

Barcellos, G.H \& Ferreira, S.B. (2007): Mulheres e eucalipto. Historias de vida e resistência. Impactos da monoculture de eucalipto sobre mulheres indígenas e Quilombolas no Espírito Santo. Movimento Mundial pelas Florestas Tropicais, Secretariado Internacional, Uruguay, http://www.wrm.org.uy/paises/Brasil/Libro_Mulheres_Brasil.pdf (accessed 2.10.2009).

Camargo, E.(2004): Lawyer, Fundação SOS Mata Atlântica. Personal communication, São Paulo, Brazil, November 2004.

Campolim, M. (2004): Director, Ilha do Cardoso State Park. Personal communication, Cananeia (SP), October 2004.

CAPOMA (2009): Soy and Agribusiness Expansion in Northwest Argentina - Legalized deforestation and community resistance: The cases of the Wichi communities of the Itiyuro River Basin and Mision Chaqueña, the Creole families of the Dorado River Basin and the Guarani communities of El Talar, http://bio-fuel-watch.blogspot.com/2009_11_01_archive.html (accessed 15.12.2009).

Carrere, R. and Lohmann, L. (1996): Pulping the South: Industrial Tree Plantations in the World Paper Economy. London: Zed Books.

Carrier, J. (2004): “Introduction”. In Carrier, J. G. (ed.) Confronting environments. Local understanding in a globalizing world. Walnut Creek: Altamira Press, pp. 1-30.

Castro Ossami de Moura, M. (2008): Etnogénesis de un grupo indígena del Brasil central. Mem. am., ene./jun. 2008, no.16-1, pp. 41-62.

Ciccarone, C. (2006): Professor of Anthropology, Ciências Sociais, UFES. Personal communication, Vitória \& Aracruz, Brazil, December 2006.

Ciccarone, C. (2004): "Drama e sensibilidade: migração, xamanismo e mulheres Mbyá". In Revista de Indias, Vol. 64, no. 230, pp. 81-96.

CIMI, Conselho Indigenista Missionário (2009): "Brasil - quadro-resumo das terras indígenas", http://www.cimi.org.br/?system=news\&eid=242 (accessed 1.12.2009)

CIMI, Conselho Indigenista Missionário (2006): "FUNAI publishes reports about Tupinkim and Guarani, Aracruz", Newsletter, February 2. 
Clastres, H. (1995): The Land-Without-Evil. Tupi-Guarani Prophetism. Urbana \& Chigaco: University of Illinois Press. (Original in French, 1975, Éditions du Seuil.)

Cota, G. (2008): O processo de escolarização dos Guarani no Espírito Santo. Vitória: UFES, Centro de Educação (Tese de Doutorado).

Dean, W. (1995): A ferro o fogo. A história e a devastação da Mata Atlântica brasileira. São Paulo: Companhia das Letras.

De'Nadai, A., Overbeek, W. and Soares, L.A. (2005): Promises of Jobs and Destruction of Work. The case of Aracruz Celulose in Brazil, World Rainforest Movement, http://www.wrm.org.uy/countries/Brazil/fase.html (accessed 24.4.2009).

Doyle, T. \& McEachern, D. (1998): Environment and Politics. London: Routledge.

Erikson, K. (1994): A New Species of Trouble. The Human Experience of Modern Disasters. New York: W.W. Norton \& Company.

Executive Commission of the Tupiniquim and Guarani \& Conselho Indigenista Missionário (CIMI) (1996): International Campaign for the Extension and Demarcation of the Indigenous Lands of the Tupiniquim and Guarani, Aracruz.

Fibria (2009): http://www.fibria.com.br/en/ (accessed 20 September 2009).

The Forests Dialogue (2008): "Dialogue on Intensively Managed Planted Forests in Brazil", 13-17 April 2008, Vitória (ES) and Mucuri (BA), Bahia,

http://environment.yale.edu/tfd/dialogues/intensively-managed-planted-forests/ (accessed 12.12.2009)

Galindo Leal, C. \& Gusmão C, I. de (eds)(2003): The Atlantic Forest of South America: Biodiversity Status, Threats, and Outlook (State of the Hotspots). Washington D.C.: Conservation International.

Haller, T., Blochlinger, A., \& John, M. (eds)(2007): Fossil Fuels, Oil Companies, and Indigenous Peoples: Strategies of multinational oil companies, states, and ethnic minorities. Berlin, Wien: LIT Verlag.

Holden, W.N. \& Jacobson, D.(2008): “Civil Society Opposition to Nonferrous Metals Mining in Guatemala", Voluntas 19, pp. 325-350.

Instituto Observatório Social (2005): Responsibilidade social na Veracel Celulose. Relatório do Projeto Veracel, firmando entre o Centro de Solidariedade Sindical da Finlândia e o Instituto Observatório Social. São Paulo: Instituto Observatório Social.

International Finance Corporation (2009): "Summary of project information" (Aracruz Celulose S.A.), available at: http://www.ifc.org/ifcext/spiwebsite1.nsf/1ca07340e47a35cd85256efb00700cee/6697586F9CB1C3 A185256EF3007CB5EE (accessed 1.5. 2009).

Kröger, M. (2008): "New Pulp Investments and Development: Lessons from Latin America and Finland". In El Norte - Finnish Journal of Latin American Studies. No. 3, April 2008, http://www.elnorte.fi/pdf/2008-3/2008_1_elnorte_kroger.pdf (accessed 12.12.2009). 
Ladeira, M.I. (2007): “O caminhar sob a luz”: o território Mbyá á beira do oceano. São Paulo: PUC, Editora UNESP.

Ladeira, M.I. (2003): “Guarani Mbya. Povos Indígenas no Brasil”, http://pib.socioambiental.org/en/povo/guarani-mbya/1292 (accessed 1.12.2009).

Ladeira, M.I. (2001): Espaço geográfico Guarani-Mbya: significado, constituição e uso. São Paulo: USP (Tese de Doutorado).

Lang, C. (2008): Europe's Role in the Expansion of the Pulp Industry in the South. World Rainforest Movement, Swedish Society for Nature Conservation, WRM (Oxfam Novib).

Langfur, H. (2006): The Forbidden Lands: Colonial Identity, Frontier Violence, and the Persistence of Brazil's Eastern Indians, 1750-1830. Stanford: Stanford University Press.

Lehtola, V.P. (1998): “Aito lappalainen ei syö haarukalla ja veitsellä. Stereotypiat ja saamelainen kulttuurintutkimus". In Tuominen, M. \& Tuulentie, S. \& Lehtola, V.P. \& Autti , M. (eds) Outamaalta tunturiin. Pohjoiset identiteetit ja mentaliteetit, Osa 1. Jyväskylä: Gummerus.

Lino, C.: 2004, CN-RBMA President, Reserva da Biosfera da Mata Atlãntica. Personal communication, São Paulo, September 2004.

Lopes, M.L.S. (2008): O que as crianças falam e quando elas se calam: o preconceito e a discriminação étnico-racial no espaço escolar (Dissertação mestrado), Vitória: UFES, Centro de Educação.

Moreno, L. (2000) Local and global: mesogovernments and territorial identities, in: In Safran, W. \& Maìz, R. (eds.): Identity and territorial autonomy in plural societies. London: Frank Cass, pp. 6175 .

Movimento de Apoio á Aracruz Celulose (2006a): “Questão indígena no ES” (PowerPoint presentation) (no date/place).

Movimento de apoio á Aracruz Celulose (2006b): “Questão indígena, Projeto básico”. Novembro 2006 (PowerPoint presentation) (no place).

Myllylä, S. (2007): “Alkuperäiskansojen kohtaaman katastrofin anatomiaa: Selluyhtiöiden yhteiskuntavastuu ja yritysetiikka Koillis-Brasiliassa”, Kosmopolis Vol. 37, no 4, pp. 27-61 [Indigenous peoples facing the anatomy of disaster: CSR and business ethics of pulp companies in the northeastern Brazil].

Myllylä, S. \& Takala, T. (2011): "Leaking legitimacies: the Finnish forest sector's entanglement in the land conflicts of Atlantic coastal Brazil”, Social Responsibility Journal (Vol 7, Issue 1).

Oberlaender, M.M. (2006): Director, Monte Pascoal National Park. Personal communication, Itamaraju (BA), Brazil, December 2006.

Parajuli, P. (1991): "Power and Knowledge in Development Discourse: New Social Movements and the State in India”. In International Social Science Journal. 127, pp. 173-190. 
Pottier, J. (2003): “Negotiating local knowledge: An introduction”. In Pottier, J. \& Bicker, A. \& Sillitoe, P. (eds): Negotiating Local Knowledge. Power and Identity in Development. London: Pluto Press, pp. 1-29.

Ribeiro, S. (2008): "Paper bullets". In ALAI, América Latina en Movimiento. 17.3.2008, http://alainet.org/active/22844\&lang=es (accessed 1.5.2009).

Ribeiro, R. (1992): “Messianic Movements in Brazil”. In Luso-Brazilian Review. Vol. 29, no. 1, pp. $71-81$

Rohter, L. (1999): “Porto Seguro Journal; Indian Tribe Wants Brazil's Plymouth Rock Back”. In The New York Times. 1.12.1999 (http://www.nytimes.com/1999/12/01/world/porto-seguro-journalindian-tribe-wants-brazil-s-plymouth-rock-back.html?pagewanted=2 (accessed 20.5.2009).

Santana, V. (2004): MST Management of Espírito Santo State, O Movimento dos Trabalhadores Rurais Sem Terra. Personal communication, Vitória, November 2004.

Saugestad, S. (2001): The Inconvenient Indigenous. Remote Area Development in Botswana, Donor Assistance, and the First People of the Kalahari. Uppsala: Nordic Africa Institute.

Seppälä, J. (2008): Vice President, Stakeholder Relations and Trade Policy, Metso Corporation. Personal communication, Finland, September 2008.

Silva, Sandro J. da (2006): Professor of Anthropology, Ciências Sociais, UFES. Personal communication, Vitória, Brazil, December 2006.

Silva, Sandro J. da (2001): "Tempo e espaço entre os Tupiniquim”. Conference presentation, Patrimônio, memória e saberes indígenas da IV Reunião de Antropologia do Mercosul, Universidade Federal do Paraná.

Sociedade Nordestina de Ecologia (2001): Dossiê Mata Atlântica 2001: projeto monitoramento participativo da Mata Atlantica. Salvador: RMA/Inst.Socioambiental/Sociedade Nordestina de Ecologia.

Soikkeli, P. (2009): Communications Director, Sustainability, Wood Supply, Stora Enso. Personal communication, Finland, May 2009.

Stora Enso (2004): “An Independent View on Veracel. Stora Enso Sustainability 2004”, http://search.storaenso.com/mini/2004/files/pdf/sr_veracel.pdf (accessed 20.4.2009).

Thomaz, L.D. and Monteiro, R. (1997): “Composição florística da Mata Atlântica de encosta da Estação Biológica de Santa Lúcia, município de Santa Teresa, ES”. In Bol. Mus. Biol. Mello Leitão. Vol. 7, pp. 3-48.

Tuhiwai Smith, Linda (1999): Decolonizing Methodologies: Research and Indigenous Peoples. London: Zed Books.

United Nations (2005): Racism, Racial Discrimination, Xenophobia and All Forms of Discrimination. Mission to Brazil. UN Economic and Social Council.

Veracel Celulose (2009a): "Forestry Operations, Forestry Partners Program", http://www.veracel.com.br/web/en/florestais/fomento.html (accessed 18.5.2009). 
Veracel Celulose (2009b): "Forestry operations, Land occupation", http://www.veracel.com.br/web/en/florestais/ (accessed 24.4.2009).

Veracel News (2003): "Pataxó Indians Learn to Grow Atlantic Forest Seedlings", October 4, 2003. http://www.veracel.com.br/web/en/outros/noticias0003.html (accessed 29.4.2009).

Warren, J.W. (2001): Racial Revolutions: Antiracism and Indian Resurgence in Brazil. Durham and London: Duke University Press.

Welch, C. (2006): "Globalization and the Transformation of Work in Rural Brazil: Agribusiness, Rural Labor Unions, and Peasant Mobilization". In International Labor and Working Class History. Vol. 70, no 1, pp. 35-60.

Whitehead, N. L. (2000): "Hans Staden and the Cultural Politics of Cannibalism". In Hispanic American Historical Review. Vol. 80, no 2, pp. 721-752. 
II

LEAKING LEGITIMACIES:

THE FINNISH FOREST SECTOR'S ENTANGLEMENT

IN THE LAND CONFLICTS OF ATLANTIC COASTAL BRAZIL

by

Susanna Myllylä \& Tuomo Takala, 2011

Social Responsibility Journal

Vol 7, No 1, 42-60 


\title{
A CONCENTRIC CSR ROADMAP MODEL FOR HOST
} COMMUNITY RELATIONSIN THE GLOBAL SOUTH

\author{
by
}

Susanna Myllylä, 2014

EJBO-Electronic Journal of Business Ethics and Organization Studies Vol 19, No 1, 27-51 


\section{A Concentric CSR Roadmap Model for Host Community Relations in the Global South}

Susanna Myllylä

\section{Abstract}

The purpose of this article is to find new Corporate Social Responsibility (CSR) approaches for corporatecommunity relationships in the global South and hence to achieve some distance from the Northern ethos. The article is based on a case study from the Brazilian pulp and paper sector. Veracel Celulose, a multinational corporation, is a joint venture between the Brazilian Fibria Celulose (formerly Aracruz Celulose) and the Swedish-Finnish Stora Enso. First, Veracel's production impacts on the Indigenous community, the Pataxó Indians, are examined. Second, Veracel's CSR policy and its subsequent impact are brought under closer scrutiny by juxtaposing corporate words with corporate actions. The findings demonstrate the many problematic dimensions of corporate philanthropy in the global South contexts: philanthropy runs a considerable risk of engaging in corporate social irresponsibility (CSI) actions in the global South. Third, the local community's own CSR expectations are presented: What constitutes responsible business practice, and what does a good relationship entail according to the Pataxó? Fourth, it would be necessary to build bridges between business ethics and development studies. In the same vein, experiences from international development can offer useful tools for communitycorporate relationship analyses. The qualitative research material of the study consists of ethnographic fieldwork data and the supporting extant literature. By combining a case study with the Grounded Theory approach, a new CSR model was created for local community stakeholder relations. This Concentric CSR Roadmap Model outlines 22 principles, and 49 sub-principles, organized in three hierarchic CSR levels: binding, ethical, and philanthropic responsibilities. Hence this article opens up a new agenda for work on CSR with Southern societies and their local communities.

\section{Keywords:}

Brazil, corporate social responsibility model, development studies, local communities, multinational corporation, pulp, stakeholder relations, Stora Enso, Fibria, Veracel

\section{Introduction}

Existing research gaps and suggestions for new paths

The new global economy has accelerated a development in which Indigenous Peoples' communities and their native territories in emerging and developing economies encounter diverse pressures from external forces. Natural resources located in Indigenous lands have become 'national and transnational resources' (Hyndman, 1988, p. 281). Multinationa corporations (MNCs) conceive Indigenous territories as open business spaces with potentially cheap or free land and infrastructure, ideal climatic conditions, low taxes, and weak environmental and labor standards. The underlying problem is that the Indigenous communities often lack legal titles to their traditiona lands, because national governments' registration of Indigenous 'reserves' is a slow process, or the governments force the heavy industrialization of these lands in the name of national progress. As a result, global corporations have had access even to most remote areas. Local needs have then been overshadowed by national governments' primary goal, that of attracting international investments by offering substantial incentives. Land conflicts and land grabbing reflect the sharp socioeconomic inequalities prevailing in Southern societies. The Indigenous Peoples and other rural communities are living on the margins of society; they are experiencing poverty, severe human rights violations, and clashes with other local actors due to unclear land ownership and overuse of natural resources. To maintain their lands, communities must generate collective responses, and concurrently, people's struggles for their territories have gained increasing global attention due to rapidly spreading social media campaigns and the subsequent public scrutiny and pressure on corporations to address social and environmental concerns. So as Kapelus (2002) remarks, when firms increasingly shift production to the global South, they also find they are not the only ones who are going global. But in spite of greater risks of harming corporate brand reputation, and substantial financial compensations to communities for economic and environmental impacts, multinationals are continuing to explore new terrains, from the Antarctic to the Arctic.

Corporate Social Responsibility (CSR) has become a powerful development agent. CSR discourses have not only entered the global South but also brought up the need to find approaches more suitable than the Northern ethos. The term 'global South' encompasses countries with rapid economic growth. These include the 'emerging economies' - the BRICSAM (Brazil, Russia, India, China, South Africa, Mexico), the ASEAN-4 (Indonesia, Malaysia, Philippines, Thailand), and the 'less developed countries'. According to Reuveny and Thompson (2007), the North-South division represents one of the main 'structural fixations' of the twenty-first century, and this division involves questions of morality and justice between the two: "what responsibilities do the well-off have toward the less well-off?" (ibid.) Hence the NorthSouth division as a wider political and economic context is closely connected to the CSR topic of this article. In addition, the notions of 'progress', 'development' and 'modernization' have led to a conception of a hierarchy of States delineated as the "Three Worlds"', and Fourth World 
theory is addressing the position of the Indigenous Peoples (Seton, 1999). Concerning primary and secondary industries, there is a growing public expectation for improved ethical performance, and companies are increasingly required to interact with Indigenous and other local communities as 'stakeholders' (Crawley and Sinclair, 2003; Lertzman and Vredenburg, 2005). Here I would like to detail six interrelated research gaps concerning local community-corporate relationships and present the contribution of my study:

1) In the last decade, the community-corporate relationship issue has attracted more interest in the field of business ethics (e.g., Rajak, 2011; Lertzman and Vredenburg, 2005; Kapelus, 2002; Crawley and Sinclair, 2003). To achieve a better understanding, this relationship can be examined by using approaches from development studies, and focusing on the needs and ethical valuations of the society, that is, the community. The community is not often considered a stakeholder group by researchers in business economics (cf. Walton, 2007). Despite emerging new, Southern contexts in CSR discourses, little research has been done to connect business ethics with development studies - and its subdiscipline, development ethics - from a stakeholder perspective. Furthermore, I argue that besides building bridges with development studies, experiences from international development (particularly in the fields of community development and project/program evaluation processes) can offer useful tools for community-corporate relationship analyses.

2) Connected closely to the previous observation, the vast majority of business ethics studies rely on secondary research and corporate reports. In-depth, primary data on the viewpoints of the corporate stakeholders at a grassroots level is rarely collected. Hence, in regard to business ethics literature, as well as researchers' training, there is a methodological lack of fieldwork practice in the global South. How can we otherwise obtain relevant knowledge in order to assess the extent to which corporate words match corporate actions at the local level? Firsthand empirical research material is also vital to better comprehend the societal circumstances and local expectations. Development studies and experiences from international development work can offer valuable theoretical insights and methodological tools (e.g., Clark, 2002; Crocker, 1998, 2008; Escobar, 1995; community participatory approach by Chambers, 1997) when assessing CSR in Southern societies. Empirical evidence is needed for theorizing and for developing practical guidelines and policy recommendations. An even bigger gap in the literature lies in the grassroots, bottom-up approaches that are based on locally defined CSR conceptualizations. Usually research seeks input only from corporate managers, NGOs, and (male) community leaders. Yet it would be essential to interview other community members of different backgrounds, such as women and youth. The question is basically who can speak for the community, since the presence of an MNC may be perceived in diverse ways among the - inherently heterogeneous - communities. Likewise, it is time to revise the position of a community as a corporate 'stakeholder', and develop new approaches and concepts that also derive from the communities' self-identification and self-determination.

3) Philanthropy is discussed rather unproblematically in the extant literature (see e.g., Vintró and Comajuncosa, 2010; Yakovleva and Vazquez-Brust, 2012). Even when researchers and firms recognize the role of CSR as a development agent, the focus is still usually on what companies do (e.g., philanthropic actions per se, or their outcomes), instead of how they approach development goals and means - in other words, how the companies handle development etbics. Additionally, the related CSR mantras, including 'partnership', 'dialogue' and 'community engagement' are often taken for granted. (See critical views, e.g. by Rajak, 2011; Jenkins and Obara, 2008; Yaacob and Wong, 2007; Hamann and Kapelus, 2004.) Again, development studies and experiences from international development work can provide valuable viewpoints here. My study found that not only business production but also CSR practices are inclined to bring about wide-ranging and unseen, problematic societal impacts, which could be avoided by adopting more accurate and binding codes of conduct.

4) CSR reports are not always a reliable source by which to assess corporate performance, since they tend to present situations in the branch countries in a rosy light. Hence the sustainability and responsibility reports deserve closer scrutiny, so it is necessary to compare corporate words with business actions. Moreover, corporate reporting needs further development.

5) A large part of the global South -related research focuses on resource-extracting industries (REIs), but the agribusiness industry and its pulpwood plantations are a much less studied subject (see Sawyer and Gomez, 2008; Kröger and Nylund, 2011). Nevertheless, MNCs' community impacts and the related business ethics questions in these sectors are similar: both depend on access to natural resources (particularly land and water) and have massive impacts on local communities' cultures, livelihoods, landscapes, and ecological systems. In addition, litthe has been written on Finnish companies' activities abroad.

6) The theoretical modeling of CSR lacks more accurate and diversified criteria in the global South contexts. My empirical research findings from the Brazilian case study demonstrate that more specified, practical, and legally binding CSR standards are needed for MNCs, as well as for the protection of local communities. I thereby introduce a Concentric CSR Roadmap Model that outlines 22 principles, and 49 sub-principles, organized in three hierarchic levels: binding, ethical, and philanthropic responsibilities. This local stakeholder-relations model is based on lessons from the case of Veracel Celulose and the Pataxó Indians in northeastern Brazil. The purpose of my model is to further deconstruct the ambiguous CSR concept, and to contribute to the disciplinary bridge-building both theoretically and methodologically between business ethics and development studies, by offering the values of ordinary people. The model is also targeted for other primary and secondary industries dealing with natural resources and local stakeholder relations.

\section{Revising the position of a 'stakeholder' - bridging the disciplines}

In business ethics Indigenous-corporate interfaces are discussed as corporations and 'fringe stakeholders' or 'external stakeholders', implying their marginal position in business decision-making and performance hierarchy. In Freeman's (1984) traditional stakeholderism, local communities are hardly discussed. As societal pressures have compelled corporations to take communities into account, they have become the most recent addition to a corporate conception of stakeholders - there is no denying that stakeholder theory has evolved (Yaacob and Wong, 2007). This new discourse also indicates that it is no longer socially acceptable to consider only shareholders when making decisions, since others also have 'stakes' in business decisions (ibid.).

Kapelus (2002) reminds us that identifying a community is a complex and contested task, and any definition of a community is always a construct (see also Walton, 2007). History, territory, kinship, religion, and culture are important determinants of Indigenous Peoples' communities - who actually define themselves. The International Labor Organization (ILO) Convention No. 169 states that self-identification is crucial for Indig- 
enous Peoples, who stress the need to recognize their collective rights. According to the United Nations' Declaration on the Rights of Indigenous Peoples (2008, and concerning its status in international law, see the United Nations General Assembly report, 2012, paragraphs 57-80):

Indigenous Peoples have the right to self-determination. By virtue of that right they freely determine their political status and freely pursue their economic, social, and cultural development

... Indigenous peoples have the right to maintain and strengthen their distinct political, legal, economic, social and cultural institutions, while retaining their right to participate fully, if they so choose, in the political, economic, social and cultural life of the State. (Articles 3 and 5 of the Declaration.)

Hence, CSR initiatives by firms - if desired at all - should also be selected by the communities themselves rather than imposed by business, national governments, or NGOs (Murphy \& Arenas, 2010). Recognizing the need to define or identify a 'community' (and some other social-science terms used in business ethics), stakeholder theory could also have benefited from the findings and debates of development studies and anthropology in particular - there is no need to reinvent the wheel. In general, 'community' has a very ambiguous position as stakeholder group in business ethics literature. Dunham, et al. (2006) discuss the stakeholder identity and 'the Problem of Community':

In other words, while we may agree that 'community' represents a legitimate and, perhaps, high priority stakeholder group, we are left with no real guidance as to the specific ethical stance the corporation should take toward any particular community constituency.

In my study, this 'ethical stance' is constructed from below, from the views of the citizens - despite the fact that many Indigenous Peoples are still excluded from society and deprived of their rights as equal citizens of a state (see International Work Group for Indigenous Affairs). On the other hand, traditional leaders have lost much of their decision-making power, while their moral legitimacy is also increasingly under attack (Kapelus, 2002).

Stakeholder management literature invariably advocates or describes processes of 'stakeholder mapping' and 'inclusion in dialogue', which represent a managerialist approach toward stakeholders (Wheeler et al., 2002). Local communities are considered merely recipient and stagnant actors. Hence this approach casts Indigenous communities as passive objects, whose lives and realities are perceived as subaltern to a global corporation's actions and who only become visible through corporate identification. Yaacob and Wong (2007) state that despite communities' legitimate role and stake in the processes concerning their lives and livelihoods, companies often fail to be proactive and responsible, particularly in involving them in the most important business processes, namely decision-making, and recognizing their cultural ties to the land. By marginalizing and neglecting their inputs and claims, corporations render a significant and legitimate stakeholder powerless and compromised. (Ibid.) Banerjee (2008) also observes that discourses of CSR and sustainable development are often defined by narrow business interests and serve to curtail those of external stakeholders. According to him, the traditional stakeholder theory basically represents a form of 'stakeholder colonialism', which merely serves to regulate stakeholders' behavior. Moreover, the traditional stakeholder theory does not significantly problema- tize who actually defines, and who qualifies as, a stakeholder. It recognizes neither the self-declaring stakeholders nor the multiplicity, complexity, ambiguity, and dynamics within the stakeholder group (see Wheeler et al., 2002). Overall, the concept of a stakeholder has been accepted uncritically in the CSR literature (Banerjee, 2008).

The position of a 'stakeholder' - the local (Indigenous) community - in the context of the global South is also reflected at the disciplinary level. While business ethics focuses on the corporate viewpoint or performance, development studies and development ethics approach the phenomenon from a different angle, by emphasizing the position of local, often marginalized communities: How do external forces - global corporations affect the local level development processes, in regard to basic needs, human rights and social justice? What kind of interfaces take place between intended development interventions and actual development processes? What are people's collective responses and claims to the firm? What are the obligations, if any, of rich societies (and their citizens) to poor societies? How can moral guidelines influence decisions of those who hold power? It can be argued that since in development studies emphasis is directed on the agency and power dynamics - namely the power distance between actors, also within a community itself as community dynamics - the 'stakeholder' concept inherently raises critical notions. Furthermore, development studies is also interested in constructions of reality, people's control over their destiny, and diverse knowledge systems. (See e.g., Crocker, 1998, 2008; Escobar, 1995; Chambers, 1997; Goulet, 1996, 1997; Astroulakis, 2013). To sum up, the stakeholder - the community - has a very different locus in business ethics and in development studies. Building more bridges between these disciplinary fields allows us to better understand the realities and claims of diverse actors and thus to see complex situations more holistically in the Indigenous-corporate interfaces. Nevertheless, it is nearly impossible to find studies in the business ethics field where authors have explicitly acknowledged the connections between business ethics and development studies or international development practices. Very few studies in business ethics have focused on the community level and personal fieldwork (cf. Bruijn and Whiteman, 2010; Reed, 2002; Lertzman and Vredenburg, 2005).

Bruijn and Whiteman (2010) found that the stakeholder position is affected by Indigenous self-identity processes, as Indigenous identity can be both threatened and strengthened in response to the corporation's actions. They also regard this as having broader implications for management ethics, and they discuss how Indigenous self-identity processes create a significant challenge for the stakeholder theory. Acting as counterweights to the company-centric stakeholder definitions, social movements can challenge a firm when they self-declare as its stakeholders (Wheeler, et al., 2002). However, few Indigenous groups actually regard themselves as 'stakeholders'; instead they discuss 'relatives of the land', 'keepers of the land', or 'rightsholders' (Bruijn and Whiteman, 2010; Whiteman, 2009).

Indigenous communities differ from other communities in terms of culture, and have particularly marginalized relationships with the state. Indigenous Peoples position natural resource management as part of an interconnected web of life that focuses on harmony and reciprocity ... Disputes over natural resources are thus embedded within concrete local ecologies and complex relations across people, flora and fauna, and the spiritual world. This ecologically embedded relational approach (Whiteman and Cooper, 2000) differs from the typical firmcen- 
tric view of stakeholder theory. (Whiteman, 2009.)

Bruijn and Whiteman found in their mining case study representing a typical situation of inequitable power relations - that communities did not self-identify with this system but instead sought to resist an externally driven identification process. Imbun (2007) points out that mainly in anthropological discourse, the host Indigenous communities appear to have become the 'significant other' in the profitable operation of mining projects.

A growing body of research has documented hostile interactions between Indigenous Peoples and MNCs. In development studies in particular, research has focused on collective action, namely analyzing new social movements staking their claims. Indigenous Peoples use multiple tactics, such as contesting the state's or the company's hegemonic discourse, building road blockades, bringing infractions against their lands to court, collaborating with non-governmental organizations, and negotiating with the companies (Yaacob and Wong, 2007). In some instances, local civil society groups have managed to shut down business operations or prevent them from starting. In addition, historical sites and events can be seen as a definer or identifier, mobilizing Indigenous Peoples' political and community responses. (Ibid.; Reed, 2002.) In recent years new social movements supporting Indigenous groups have not only been a new factor in the greening of companies, but they have also affected the power balances in Indigenous-corporate relations. At first glance, local communities may be perceived as powerless stakeholders compared to large corporations. However, the Internet and related social media have exposed conflicts in even the most geographically remote areas under worldwide online scrutiny. Hence globalization has enabled the Indigenous Peoples and their supporting groups to present themselves as legitimate and prominent stakeholders (Yaacob and Wong, 2007).

If the company fails to publicly acknowledge a social movement as a legitimate stakeholder, it can easily spark conflicts and brand reputation problems (Wheeler et al., 2002). The famous case of Shell and the Ogoni people in Nigeria provides an example of a typical company-centric stakeholder definition process, where Shell preferred certain groups even though they did not represent the majority of the Ogoni (ibid.). The inconvenient citizens' groups were ignored in the hope that they would eventually lose their influence. In case of the latter ones, recognition also required third-party legitimation through internationalization of the Ogoni issue with the assistance of Amnesty International, among other influential actors. Thus the Movement for the Survival of the Ogoni People (MOSOP) was not a single stakeholder but represented a diverse set of overlapping interests. This posed a significant challenge for Shell in managing complexity, particularly when MOSOP split and new divisions emerged. Employing divisive rhetoric, the company still attempted to define legitimate stakeholders by denying legitimacy to those Ogoni groups that could claim status as separate stakeholders. In conclusion, the company wanted MOSOP to speak as one voice for the entire Ogoni people. (Ibid.) Furthermore, Wheeler et al. (2002) conclude that "a truly stakeholder-responsive approach demands the acceptance of multiple stakeholders and requires the company to develop a tolerance for ambiguity together with the sensitivities and capabilities needed to inspire trust with diverse and sometimes competing interests". On the other hand, the authors point out that an MNC is not a homogeneous entity either: there may be great differences among its branch firms, as well as between managers. The authors rightly ask: since the corporation can exhibit contradictions and incon- sistencies in its behavior and rhetoric, how can a stakeholder group relate effectively to it? (Ibid.). Thus heterogeneity within both actors creates complex situations, and identifying the other actor requires careful assessments.

\section{Development or dependency? Problematizing philanthropy}

A corporate social initiative can be defined as a program, practice, or policy undertaken by a business firm to benefit society. These not only include the traditional practice of corporate philanthropy but can also encompass a variety of forms and points of focus, ranging from corporate support for training and educating adults and youth in local communities, to nationwide programs helping welfare recipients get jobs, to globally focused efforts providing aid to developing countries. (Hess, et al, 2002; Brønn and Vidaver-Cohen, 2009.) Local investments by MNCs have traditionally included either donations to charities, which then assumes responsibility for delivering social outcomes, or direct management of social investment in-house (Reed, 2002). When comparing various MNC industries - e.g., pulp and paper, REIs, mining, and oil - and their community relations, the impacts, corporate responsibility questions, and responses are very similar. Positive effects may include community health initiatives, infrastructure improvements, local business support, income from export revenues and royalties, technology transfer, skilled employment, and training for local populations (see Jenkins and Obara, 2008). Many MNCs have also committed themselves to more open reporting, and multi-stakeholder committees have been established to involve civil society actors. REIs in particular have actively sought more responsible business practices, although they also have a mixed record. Companies have been forced to take into account the wealth of local communities and their environments, and thus large corporations have spent millions of dollars to fund diverse sociocultural activities. (See Reed, 2002; Kapelus, 2002; Vintró and Comajuncosa, 2010.)

Companies have responded to social demands, such as stakeholder activism, and sought to widen the traditional stakeholder approach by introducing 'community engagement' in their businesses. Firms have thus realized that they need to deal with local communities as part of the wider agenda of CSR and sustainable development in order to win societal legitimacy. Some businesses aim to partner straightforwardly with Indigenous populations, via established CSR programs in terms of the stakeholder management, or by funding infrastructure and economic development projects. Firms often attempt to gain Indigenous consent by providing social works and services, such as schools and medical clinics. (Murphy and Arenas, 2011.) REIs are increasingly willing to consult with local communities, take their concerns into consideration, and possibly modify their plans (Reed, 2002). In addition to the more positive effects of employment generation and spin-off activities, which firms tend to highlight, there are also a range of potential negative economic impacts associated with these industries, such as dis possession of local inhabitants from their land and the degradation of lands and related resources that reduce their productive capacity (Reed, 2002). The critics argue that rather than providing 'compelling examples of collaboration', these efforts often serve primarily to neutralize and depoliticize Indigenous resistance, while ensuring that firms maintain licenses to operate in Indigenous territories (Hamann and Kapelus, 2004; see also Sawyer and Gomez, 2008; Seton, 1999).

It could be stated that since corporate impacts are felt most deeply at the local level, focusing on the community initiatives is also relevant (Jenkins and Obara, 2008). However, with a few 
exceptions, philanthropy in the global South cases is discussed rather unproblematically in business ethics research, i.e., it is taken for granted as a 'doing good' CSR approach. The presence of industries in the global South merits further examination, particularly those (like REIs) that possess a relatively long history of such involvement: Have the industries' CSR approaches effectively addressed the development concerns of local communities, and how have the firms contributed to local sustainable development (Kapelus, 2002; Reed, 2002; Jenkins and Obara, 2008)? Sagebien and Whellams (2010) have examined the role of CSR in the development agenda, whether CSR is 'good or bad development', and what its role is in sustainable development debates. A causal relationship has been found between CSR and 'corporate social irresponsibility' (CSI): when companies do more 'harm' they also do more 'good' (Kotchen and Moon, 2011). Mounting evidence indicates a gap between the companies' stated intentions and their actual behavior and impact in the real world (Frynas, 2005). The proposed bi-polar, dualistic model by Jones, Bowd and Tench (2009) is aimed at analyzing CSR business practice in terms of a sliding scale of 'doing good' (CSR) as well as 'doing bad' (CSI). The authors charge that CSR is often wrongly equated with irresponsible corporate actions. Also corporate communication varies accordingly, e.g. "from minimal community consultation and involvement" (CSI) vs. "maximize opportunities for community consultation and involvement" (CSR). (Ibid.) Although community initiatives may represent welcome development contributors, they have little impact on the root causes of socioeconomic problems deriving from the colonial and apartheid histories of Southern countries. Furthermore, these historical legacies usually pose obstacles to socioeconomic change. Often industries generate informal settlements, squatter camps in their neighborhoods, creating deteriorating social conditions, such as unemployment and crime. In fact, the topics of employment and housing have generally been ignored in companies' sustainability reports. (Hamann and Kapelus, 2004.) A number of authors conclude that businesses have engaged with Indigenous communities primarily as a means to their own ends, and implementation of community projects has created even deeper poverty (see Murphy and Arenas, 2010).

Kapelus (2002) notes that the CSR literature is permeated with references to how corporations can portray themselves as being 'part of the community'. Guidelines provide practical instructions for managers on how to establish good relations with the communities. He reminds us that not only do corporations themselves "provide the community a place of prominence in the CSR agenda", but international financial organizations also highlight the importance of creating relationships with local communities. Corporations' increasing knowledge about the local population through philanthropy poses an even larger threat to the population. (Ibid.) In this sense, 'community engagement' is a double-edged sword. Yaacob and Wong (2007) state that in regard to the logging and plantation industries in the Indonesian Sarawak case, government and local companies seldom include the local communities in the decision-making process, even when their social-cultural mores and practices are adversely affected. Due to the lack of consultation, enforcement at the local level, or proper monitoring, these industries cause many problems for both the natural environment and Indigenous Peoples. (Ibid.) Environmental damage caused by agribusiness often results in the loss of land for livelihood, which leads to greater dependency on the industry (see e.g. Velame, 2010).

Through a multi-sited ethnography Rajak (2011) tracks trans-local dimensions by studying a transnational mining corporation in South Africa. She uses an anthropological approach to transnational processes of corporate capitalism. Rajak presents a critical example of how CSR enables a corporation to accumulate and exercise power over poor communities, resulting in a dependency situation. She illuminates "how old regimes of corporate paternalism are reinvented within a modern morality of social responsibility" (ibid., pp. 10-13). Furthermore, she argues that "the moral economy of CSR represents, not an opposition to the contemporary world of corporate capitalism, nor a limit to it, but the very mechanism through which corporate power is replenished, extended and fortified" (ibid., p. 239).

Frynas (2005) identifies a dependency mentality whereby communities expect a company to provide them with resources as a compensation for social and environmental damages. Jenkins and Obara (2008), studying multinational mining companies in Ghana, have examined how corporate community initiatives may actually create community dependency at the national, regional, and local level. They point out that, intentionally or unintentionally, this can have serious consequences for the dependent community, particularly after the industry closes. Moreover, corporate 'consultation' is often considered the key to ensuring an equitable distribution of benefits. However, many communities lack the capacity to negotiate in the consultation process, because they are not organized enough and are even weaker negotiating smaller units. Furthermore, MNCs have more access to information and the relevant skills both to bargain for their benefits and to decide what benefits may be distributed to the communities. Some companies then exploit the situation, which results in a raw deal. (Ibid.) According to Jenkins and Obara, there are other capacity limitations that exacerbate problems in the consultation process, such as inadequate or nonexistent objective baseline data that can serve as benchmarks in enforcing standards. The absence and the enforcement of a legal framework providing adequate rights for communities is also a limitation. The authors conclude that there is a fine line between dependency and development by CSR. (Ibid.). Banerjee (2008) acknowledges that although stakeholder empowerment is a noble goal, the situation in which stakeholders and the firm have opposing agendas is problematic in regard to the firm's economic performance and its 'empowering' role towards local communities. The theoreti$\mathrm{cal}$ principles of CSR can be seamlessly integrated into corporate policy statements, and glossy corporate social reports often hide grim realities (ibid.). The 'local consultation process' with MNCs can be seen as representing a top-down corporate practice, occurring in unbalanced power conditions, primarily serving the corporate interest, and offering no zero option for local people i.e. the company withdraws from the investment.

\section{On CSR criteria in local stakeholder context}

Pressured by financial institutions, multilateral bodies, and civil society groups, industries have attempted to establish and adopt a number CSR indicators, 'best practices', 'independent' standards or codes of conduct, most of which attempt to guide firms in environmental issues. The OECD Guidelines for Multinational Enterprises are recommendations and voluntary principles addressed by governments to multinational enterprises, in areas such as human rights, environment and employment. Concerning corporate stakeholder relations, the ISO (International Organization for Standardization) 26000 provides guidance on how businesses and organizations can operate in a socially responsible way. A network-based non-gov- 
ernmental organization, the Global Reporting Initiative (GRI), aims to drive sustainability, and it produces the world's most widely used sustainability-reporting framework. Environmental, Social, and Corporate Governance (ESG) has three central factors in measuring the sustainability and ethical impact of an investment in a company or business. ESG encompasses the criteria used in socially responsible investing. There are also guidelines in order to relate the Social Responsibility (SR) guidance in ISO 26000 to reporting guidance provided by GRI. The United Nations Global Compact is "is a strategic policy initiative for businesses that are committed to aligning their operations and strategies with ten universally accepted principles in the areas of human rights, labor, environment and anti-corruption" (United Nations Global Compact). Given the recent international case studies, and the voluntary nature of CSR, it is obvious that various guidelines and standardization systems have remained toothless concerning the corporate-community stakeholder issue.

The theoretical modeling of CSR also lacks more accurate and diversified criteria in the global South contexts. There is also a great demand for more practical-level, specified standards. In the field of research, Lertzman and Vredenburg (2005) want to expand the discussion of relations between Indigenous Peoples and resource extraction companies by referring to concepts of sustainable development, traditional ecological knowledge, and cross-cultural bridging or dialogue. Crawley and Sinclair (2003) argue that only initiatives that aim at power sharing with Indigenous groups, and strategies for broadening the organizational interface with them, will contribute to more ethical practices. The authors suggest an ethical model for human resource practices between Indigenous Peoples and mining sector. They emphasize the importance of Indigenous cultures, the need for power-sharing and two-way learning between the actors, and relationship-building as the basis for long-term engagement. They offer four ethical criteria for Indigenous-corporate relations and a model for locating company practices. The authors also consider the reasons as to "what causes one company to be resistant and minimalist in its approach, while another pursues a more innovative and visionary path". Furthermore, they argue that the chief executive officers' stance and level of commitment is probably the most important influence on a company's relations with Indigenous Peoples. (Ibid.) In the same vein, Bruijin and Whiteman (2010) state that without effective institutional power-sharing, firms may not be able to adequately balance ethical concerns with their vested interests. The authors suggest that firms can develop an ethical relationship through extended intercultural dialogue and shared institution-building. The authors are also aware of the distinct power imbalances as a hindrance to more ethical relationships, since many Indigenous Peoples lack land rights. Thus institutionalization of the collaboration, high-quality and frequent communication, and high levels of trust are essential elements in collaboration (ibid.).

Murphy and Arenas (2010) propose a theoretical framework of six principles for cross-cultural partnership creation between businesses and fringe stakeholders; a Cross-Sector Collaboration Matrix. It presents a wide range of possibilities to move from "collaborations focused on conflict resolution to those based on integrative relationships requiring the capabilities of organizations across sectors [e.g., civil society organizations] and cultures to achieve innovative solutions to social problems". $\mathrm{Xu}$ and Yang (2009) identify China's indigenous conceptual dimensions of CSR and seek to address the knowledge and comprehension of CSR in a specific context. They note that CSR got off to a late start in China and has yet to establish a good conceptual system. Since the existing conceptual scope and research of CSR are all based on Western research and findings, they see it as urgent to build a CSR conceptual framework tailored to China's unique circumstances. Based on inductive analysis, they derive nine dimensions of China's CSR and define the meaning and key elements of China's CSR. Vintró and Comajuncosa (2010; see also Carneiro, 2008) introduce a rough set of criteria, a 'CSR performance chart' for mining industry, in terms of sustainability, ethics, and human capital. The ethics section contains the "promotion of local community economy and social work". In addition, environmental safety and human rights are included. From local communities' viewpoint, the problem with the CSR chart may be that it focuses only on those actions and results that can be assessed primarily in monetary terms. Yakovleva and Vazquez-Brust (2012) use the concept of 'Corporate Social Responsibility Orientation' to contrast the perceptions of major stakeholders and examine adaptation of mining companies' CSR orientation to local context in Argentina. It is useful to monitor CSR within a wider array of actors in order to gain a more integrated perception of the situation. However, their field research data included only the upper strata of civil society, namely the academics and NGOs, and very few grassroots movement representatives.

Lertzman and Vredenburg (2005) state that unless mutual benefits and common ground can be identified, there can be no ethical basis for stakeholder relations. Kapelus (2002) suggests that the relationship between the firm and the community has to be businesslike rather than philanthropic. Bruijn and Whiteman (2010) remind us of the nature of local communities, which are usually more or less heterogeneous actors, hence a greater nuance in looking at them is needed. To cite an example, individuals may simultaneously accept temporary employment and yet at the community level strongly resist business and its impact. In regard to Indigenous Peoples in particular, community engagement can be rather problematic. (Ibid.) Thus issues such as human rights and activism should be included in stakeholder discourses (Yaacob and Wong, 2007). Jenkins and Obara (2008) argue that currently there is no assessment of the success or failure of community initiatives: independent benchmarks for what constitutes a successful program are lacking. At this point, I see that community development questions in the contexts of international development work and development studies can offer guidance in assessing community initiatives. But the key question remains: given their negative impacts, can corporations be accepted as proper actors to intervene in communities' quality of life in other spheres as well? Does philanthropy function, then, as a immoral way to buy off communities? According to Yaacob and Wong (2007):

...(e)ven if organizations are indeed engaging people, this may be a producer of the trend towards managerial control enabling organizations to exert more power over community members through developing an ever greater understanding of their lives.

More critical perspectives by Hamann and Kapelus (2004) note that CSR is primarily about greenwash, or "the projection of a caring image without significant change to socially or environmentally harmful business practices". The authors urge more sincere forms of CSR, based on accountability and fairness. Lertzman and Vredenburg (2005) argue that it is unethical to sacrifice the viability of Indigenous cultures for industrial resource extraction. Murphy and Arenas (2010) state that any industry depending on access to natural resources needs a license to operate from local communities, in addition to national 
governments, which regulate the use of these resources. 'Social license' refers to a local community's acceptance or approval of a company's project or ongoing presence in an area.

It has been argued that CSR should incorporate more awareness of the historical and institutional dynamics of local communities. In other words, there is a need for a deeper and richer understanding of the community engagement experiences, and of the historical and social processes that have defined them (Yaacob and Wong, 2007). This, in turn, influences the type and range of responsibilities the firm can be expected to carry out. It also reveals the limitations of any universal codes of conduct (cf. Husted and Allen, 2006). At the same time, it requires the firm to go beyond the 'best practices', which can be seen as a product of managerialist thinking. (Ibid.) There is also a need for 'non-intimidating communication' with local constituencies, meaning that a firm must temper its power and influence by recognizing and responding to local concerns in the pursuit of its own objectives. New questions should be asked, for instance: "Who is doing the representing?" "What is represented?" and "Why is it represented as such?". (Ibid.)

Banerjee (2008) divides CSR research on two major groups holding divergent views: from the CSR-suspicious, corporatecentered 'Friedman camp' to a widely inclusive stakeholder framework. As some scholars have emphasized the need for a more restrictive stakeholder concept, the focus is placed on those stakeholders who can influence the firm's financial and competitive position. This approach makes CSR a kind of a service strategy to sustain the firm's competitive advantage. According to Hamann and Kapelus (2004), in any assessment of CSR policies and practices, the key criteria should be based on helping the most vulnerable. Reed (2002) reminds us of the political context of Southern nations; frequently neither markets nor the institutions of political democracy function in "ways that even nearly approximate the ideal". When firms seek to maximize shareholder values in these societal circumstances, it does not contribute to a common good. As seen in the Indigenous territories' question, as long as the institutions and practices of political democracy are deficient, governments cannot develop and enforce legislation encouraging more responsible business practices, which effectively protects citizens' rights or otherwise meets people's pressing needs. In addition, Reed poses an important normative question as to whether and to what extent deficiencies in markets and the institutions of political democracy impose greater responsibilities upon them to assist the needy and to develop their own standards of conduct:

The question whether firms should operate in non-democratic environments has been largely determined by firms themselves (rather than on the basis of public discourse and democratic

decision-making)... is normatively... a controversial question, a is the 'realist' understanding of legitimacy upon which it is based (Reed, 2002).

The voluntary character of CSR is a fundamentally problematic question. Firms may operate under a low level of government regulation, often not maintaining even adequate minimum standards and enforcement. This critical notion of existing standards will obviously pave the way for more stringent regulation of MNCs - as a response to societal messages that such corporate responses are no longer optional (Kapelus, 2002): "TNCs [transnational corporations] might be encouraged to apply their home standards abroad, when they move to locations with lower labor costs and less stringent environmental regulations" (ibid.). Hence the CSR debates have emphasized the strengthening of corporate regulation at the national and universal level, by developing legally binding criteria (cf. Husted and Allen, 2006; Yaacob and Wong, 2007; Banerjee, 2008), and moving from softer laws to harder laws. However, laws and other regulations are not enforced in many occassions:

...This leads to a paradox: despite the burgeoning number of international charters, state constitutions and national laws across the world that assert and protect the rights of indigenous peoples, the majority find themselves increasingly subjected to discrimination, exploitation, dispossession and racism... The study argues that public-private partnerships studied here eventually led to institutional capture, undermining the neutrality of the state and its capacity to protect indigenous communities. It stresses the need for governments and international agencies to create inclusive consultative platforms so that indigenous groups could have a say in decisions that affect them. (Sawyer and Gomez, 2008, p. iii.)

\section{The case study: What role do the Finnish companies} play in Brazilian society?

The Bahia region and its Indigenous history

Brazil was 'discovered' 500 years ago when the Portuguese fleet arrived at the Discovery Coast, at what is now the south of the State of Bahia. The region was covered by Atlantic rainforest, and its high point, Monte Pascoal - now a national park - was the first sight seen by the Portuguese, who claimed the territory for their crown. The coast was inhabited by native tribes, whose remaining descendents are the Pataxó and the Tupinambá Indians living in aldeias. Some of these villages have been officially recognized as Indian 'reserves', while others await official status.

The juridical position of the Brazilian Indigenous Peoples is very complex and delayed. ILO Convention No. 169 is the most important operative international law that is meant to guarantee the rights of Indigenous nations. The convention is a legally binding international instrument, which deals specifically with the rights of Indigenous and tribal peoples, and Brazil ratified the Convention in 2004. The 1988 Brazilian Constitution recognizes the inalienable right and ownership of Indigenous Peoples to lands they have traditionally occupied: the Indians are the first and rightful owners of Brazilian lands. 'Indigenous Lands' is a juridical concept established by the constitution, and it is also defined in specific legislation: the Statute of the Brazilian Indian (Law 6001/73), which has been under revision by the National Congress. This law regulates the rights of Brazil's Indigenous Peoples (Pires, 2011; Povos Indígenas no Brasil). The most recent version, the New Indigenous Statute (Bill 2057/91), has been awaiting a vote in Brazil's House of Representatives, because the legislation's parameters have been debated. This bill was introduced in 1991, delayed in 1994, and put back on the agenda in 2009. The legislation deals with issues such as laws mandating punishment for crimes against the Indigenous Peoples, the defining of land borders, the use of forest resources, and environmental protection. Since the new statute became outdated, it needed to be rewritten - an observation based on discussions between the Indigenous groups and the government. The role of Indigenous Peoples in the national debates is mandated by ILO Convention No. 169, which calls for the participation of interested parties whenever legislative or administrative measures are discussed that could affect the Indigenous Peoples. The Ministry of Justice presented a new statute text in 2009, based on ILO Convention No. 169 and the 
1988 Federal Constitution. However, the Indigenous movement and the National Commission of Indigenous Policies have been pushing for a substitute bill, because they claim that Bill 2057/91 has gaps. For instance, the shift in the regional composition of Indigenous villages needs to be taken into account: more than 40 percent of Brazil's Indigenous Peoples now live in large urban centers. According to the 2010 census, Brazil's Indigenous population numbers 800,000 , including 300,000 living in cities. Meanwhile, Law 6001/73 remains in effect. (Pires, 2011.)

For a territory to gain full protection, a multi-level process towards official registration of the Indigenous territories is carried out by the National Indian Foundation (FUNAI), which is a government body. Resolving territorial disputes has been one of FUNAI's priorities since 2011 (Pires, 2011). However, many native territories linger in a long-term ambiguous status as a result of FUNAI's delay in identifying and registering them. This has led to complex local disputes. For instance, many Indigenous lands are occupied by companies, mega-projects, ranches, and hotels, all which have led to human rights abuses against the Indians and protracted legal battles. Even after the legal title is secured, outsiders frequently encroach on the Indigenous territories. This is also the case with the Pataxó Indigenous community focused on in this article.

Before the arrival of the pulp mills and eucalyptus plantations, Bahia was already heavily deforested to make way for sugar and tobacco plantations. The remains of the Atlantic primary rainforest consist of an archipelago of strictly protected forest islands. Apart from forestry, the main livelihood activities of the Pataxó include low-yield livestock production, traditional fishing in the coastal zone, and tourism. The Pataxó villages are in diverse locations in relation to Veracel's eucalyptus plantations; while some are surrounded by them, some have less direct contact. The number of Pataxó villages has been increasing due to the spread of the population. In 2011 there were 14 Pataxó villages, consisting of 11,436 people.

\section{Veracel Celulose S.A.}

In 2005 Veracel's pulp mill started operations in the city of Eunápolis. Veracel Celulose S.A. is a joint venture formed by Fibria Celulose S.A. - previously Aracruz Celulose S.A. - and the Swedish-Finnish Stora Enso, in which both own a 50 percent stake. Concerning Veracel's background, in 2009 Aracruz merged with its Brazilian rival, Votorantim Celulose e Papel, and Fibria is a result of the acquisition of Aracruz by Votorantim; from now on I will refer to Fibria/Aracruz. Furthermore, Veracel led to a series of lucrative contracts for European and Nordic companies1. Veracel's annual production capacity is 1,2 million tons of cellulose, and about 90 percent of the pulp is produced for export. Veracel's total land area of 211,380 ha is distributed in ten municipalities in the south of the State of Bahia. Plantations occupy 94,866 ha. (Veracel Celulose, 2013, p. 4,11 .) The rest is destined for environmental recovery and preservation, and a small percentage for infrastructure. According to the company, expansion of production capacity will also impact Veracel's forest base, which "must be increased by a further 107,000 hectares, involving another six municipalities". Furthermore, they have licenses to continue with the company's expansion project, as decided by the shareholders; implementation of the program will enable the company to expand the factory's present capacity of 1,2 million to 2,7 million tons of cellulose a year (Veracel Celulose, 2013, p. 4) - that is, to double the production capacity, which illustrates the continuous growth logic of agribusiness.
Many scientists and civil society organizations have severely criticized Veracel for being involved in the global land grab and destroying the region's economic base by buying or renting small or medium-sized rural properties. The planting of eucalyptus, called the 'green desert', has caused numerous severe disputes with and between various local actors. (See e.g., Velame, 2010.) In the agribusiness debates, the Indigenous Peoples' situation has remained marginal compared to that of the landless rural workers movement (see Kröger and Nylund, 2011).

\section{Methods and materials}

The CSR discourses and definitions usually take place in a top-down manner, led by company managers, scientists, civic organizations, and various international institutions. In addition, the vast majority of local stakeholder studies tend to limit themselves to the statements offered by company management and NGOs, and do not include voices from the community. Furthermore, NGOs are not always the best representatives of the communities, due to their own stakes and mutual power struggles. It is ultimately a question of those people in whose backyard the multinational is located, and their viewpoints are barely presented in the business ethics studies in the global South contexts. Hence, instead of mainly relying on the CSR literature and corporate-based materials, the subject is examined here from 'below', at the grassroots level. The firsthand empirical material provides the basis for the generation of conceptual CSR model, in order to present accurate criteria for the local stakeholder-corporate relations in the global South.

Adapting the approaches from the Grounded Theory (GT) has several assets. First, it is ideal for "exploring integral social relationships and the behavior of groups where there has been little exploration of the contextual factors that affect individual's lives" (Crooks, 2001.) Second, as a constructivist methodology, GT arises from interaction between the researcher and participants, the researcher's perspective being part of the process. The researcher's task is to try to understand what the participants see as being significant and important. Third, GT allows the inductive construction of abstract categories developed from data, and not from pre-existing conceptualizations. GT enables theoretical sensitivity and gives space to a relevant, new theoretical framework or model, rather than verifying or falsifying any existing theory from the beginning. Fourth, the literature review takes a secondary role: it offers a point of reference, rather than predetermined ideas, so the researcher can be as sensitive to the data as possible. Hence the bulk of the literature review is conducted after the emergence of a new theoretical framework. The extant literature is integrated into the study as data. In addition, certain benefits can be found in combining the GT method with the case study method. It is an appropriate way to research a previously little-studied area. The research can also generate theories and models from practice. (See Fernández, 2004; Urquhart and Fernández, 2006; Strauss and Corbin, 1990, pp. 49-50.)

My aim was to generate a theoretical conceptualization - a CSR model - grounded in case study data, by adapting some GT elements, namely the data-based inductive method and conceptual categories, and by using the extant literature in later stages of the research process to support the empirical data. The initial research task was to understand the corporate impact and the CSR expectations from the Indigenous perspective in the case of the Pataxó Indians and Veracel Celulose. The data was collected by using ethnographic methods, which included open-ended face-to-face interviews, leaving space for free discussions and the interviewees' own narratives. Interviews were 
done among the Pataxó community members from 6 aldeias or villages, representing various ages and genders, and by individual and group discussions. These discussions were carefully recorded by taking written notes. Personal observations were also made during the visits to the villages. The field trips were made in two phases. The preliminary study was carried out in December 2006, when a few NGOs and villages were visited. In May 2011 the research began with discussions with the Brazilian anthropologists, who also helped in gaining access to the aldeias, most of which were closed to outsiders. Before starting the interviews, I had to receive permission from each of the village chiefs, the caciques. I chose villages to visit that were in a wide range of locations in relation to Veracel's plantations, as well as being accessible. Heavy rains and roads in bad repair hindered access to some of the villages.

This case study is part of my longitudinal research project on the Indigenous-corporate relationship in northeastern Brazil. In my previous field trips in 2004 and 2006, I examined another case study from the neighboring State of Espírito Santo, involving the same company: the Indigenous-corporate relations between Fibria/Aracruz and the allied Tupinikim and the Guaraní Indians (Myllylä, 2010; Myllylä and Takala, 2011). This reference case has been used as a part of the GT data. In addition to interviews and discussions with the Indigenous groups and with Brazilian scholars, I spoke with Stora Enso Sustainability Communications group in Finland. Extant literature, including corporate reports and press coverage, provided the rest of the data.

\section{Structure of the article}

After having introduced the research framework of my case study and the supporting extant literature, in the following I will present the empirical findings from the Brazilian case study. In the second and the third chapter Veracel's impact on the local communities is analyzed in terms of i) pulp production on the Pataxó Indians' livelihoods, ii) assessment of corporate social responsibility initiatives, and iii) grassroots CSR definitions. In the fourth chapter field research results are juxtaposed with corporate performance and reporting. In addition, I compare research findings to a reference case from another Brazilian state. Next I suggest a hierarchic, concentric CSR Roadmap model. Finally, I summarize the main conclusions of the article.

\section{Veracel's pulp production impacts}

Intensified land disputes and racism

In the initial phases of Veracel's establishment, the company announced that the area did not have Indians when it arrived. The Pataxó aldeias were approached differently; meetings took place with only certain villages and their chiefs. Concerning the company's land acquisition, the indirect role of the local planters or fazendeiros (cattlemen) in preparing lands for sales to Veracel has been critical. Specifically, a village that has had prolonged conflicts with these land subcontractors was not negotiated with. The fazendeiros have occupied and cultivated areas that have generally been known as Pataxó Indigenous Territory, in which they have used violence against the Indians and set up electric fences around the areas taken.

Veracel has also planted eucalyptus in the Indigenous territory. According to the company, this land area is 'only' 6 percent (approximately 3,120 ha) of the Pataxó Indigenous Territory $(52,000 \mathrm{ha})$. For instance, the Guaxuma village has had an ongoing dispute concerning 70 hectares of land that the company had purchased from the fazendeiros. In addition, it was claimed that the company has not obeyed the 12-kilometer buffer zone rule concerning the protected forest area.

The major problem underlying the land disputes has been the fact that FUNAI should have demarcated the Pataxó Indigenous Territory a long time ago. This would have secured the land tenure of the Pataxó and spared them from various forms of discrimination as well as from having to seek redress in court. FUNAI's researchers have identified the Indigenous territory on an official map, which also has been published in Bahia State and in the capital, Brasília. Two caciques pointed out:

The fazendeiros are constantly against the Indians in the court, or in conflict, and the land demarcation is too slow.

FUNAI is dependent on the actors in Brasília - they should come here but they "keep the paper at the bottom of the drawer". The fazendeiros are the obstacle, because they claim ownership of the land. The government should buy them out from the disputed land areas.

According to the villagers, the fazendeiros constitute a powerful counterforce to FUNAI, which is afraid of them, and this situation has actually slowed down the official registration of the Pataxó Indigenous Territory. As a result, some villages live under a constant state of insecurity due to threats of eviction by police. People often link the problematic situation to Veracel's presence:

Veracel is preventing the formalization of the Indigenous territory.

Veracel has misused the land.

The company brings more bad than good in any form - as a whole I do not accept it.

My big concern is that eucalyptus is important only for the company, but not for the people.

The continuous spread of eucalyptus plantations and diminishing land resources has also increased disputes between other actors: the Indians and the landless rural peasants. Hence another, albeit indirect, impact of Veracel's presence concerns the mutual relations of local actors. The official registration of the Indigenous territory will affect many local actors - not only the Monte Pascoal National Park, but also Veracel, since its plantations are situated within this area. Thus the company must soon withdraw and restore this land, all of which has financial implications for the company.

When defending their traditional land rights, the Pataxó pointed out that they are forced to encounter racism in various forms, which is again linked to the chain of impacts due to a spreading plantation economy:

We have faced racism - claims that we are not 'genuine Indians' - from the government's side. In the health centers we also experience it, since we are put last in line for treatment: some of the doctors are descendants of the fazendeiros. The reason for discrimination is that we are persistent about our land rights. We are very tired and depressed because of this situation.

Since the Indigenous territory is not demarcated, others besides the fazendeiros also attempt to claim these traditional lands by asserting that the Pataxó are 'false Indians'. The same ar- 
gument has also appeared in another land dispute case in the southern State of Espírito Santo, where Fibria's/Aracruz's one tactic was to claim that the Tupinikim do not represent 'authentic' Indian culture, based on the report prepared by the anthropologists of Aracruz (Myllylä, 2010; Myllylä and Takala, 2011).

Reduced livelihood opportunities and social problems

Before Veracel's establishment the Pataxó had subsistence from the remaining segments of the Atlantic forest. As if the reduction in Pataxó living opportunities over the last 500 years were not enough, the emerging new pulp investments have further reduced people's traditional means of subsistence. Massive monoculture plantations and their crude land-management practices have driven wildlife away, which has considerably affected the livelihood strategies of the Pataxó. They could hunt and fish without restrictions before Veracel's arrival. In addition, due to stricter environmental legislation, Bahia's remaining natural resources have come under tighter scrutiny by IBAMA (the Brazilian Institute for the Environment and Renewable Natural Resources). Thus road signs prohibiting hunting or fishing are common, and Veracel has even placed its own road signs on the borders of plantations to forbid hunting and fishing. These signs also warn against committing environmental crimes and request nature protection. Perversely, a pulp corporation has turned itself into a nature-protection authority in the region.

When plantations were founded, Veracel's armed security men prevented some Pataxó from fishing and evicted them, although this incident occurred in the Indigenous village territory. After the Pataxó contacted a lawyer, the company was not allowed to create any restrictions or place such road signs in that specific area.

Now we do not hunt or fish within our territory or a protected nature reserve, but we fish in the sea. Yet hunting is important for our living. After several years our grandchildren cannot see nature anymore. That is why some protected areas exist here. Before the new environmental law we hunted pacas and armadillos, for instance. These new laws are difficult for us - we cannot fully understand them, because since birth we have been used to hunting freely. The eucalyptus is a tree that birds do not enjoy staying in. In plantations you cannot find any pacas and armadillos, because they cannot survive well there. It is possible to walk a long way without finding any wild animals.

The above situation is very similar to the case of Espírito Santo State: Fibria's/Aracruz's eucalyptus plantations have been harmful to entire ecosystems, and scarce natural forests have prompted environmental officials to relentlessly scrutinize the Indians' livelihood practices (Myllylä, 2010; Myllylä and Takala, 2011). Declining natural resources have also pushed the Pataxó to overuse endangered hardwood species for tourism handicrafts. People have different approaches to the remaining forests: some prefer conservation, while others want logging for commercial purposes. Some villages have their own forest reserves, and tree-logging is regulated by IBAMA's permissions. The villagers have to reforest the logged sites. However, the divided situation has caused tensions among the Pataxó, particularly when the co-management of Monte Pascoal National Park by IBAMA and the Indians was temporarily introduced: it assigned some of the community members to supervise others.

Hence many of the livelihood-related problems in Bahia are quite similar to Espírito Santo, which Pataxó chiefs had earlier visited, and observed ecological problems in the TupinikimGuaraní Indigenous Territory. In Bahia, many chiefs shared a common view, but there were also different opinions:

Eucalyptus is bad because it dries up the rivers.

There are no benefits from plantations, which are harmful to health and nature. Veracel's plantations within the Pataxó territory dry the soil and destroy land - there is no benefit for us.

No negative impacts to this village due to long distance.

Plantations are located too close to the national park, which is illegal. The worst thing is that agrotoxins are used.

One of the chiefs gave a unique opinion, which raises a question whose rhetoric it was about after all:

Veracel is a company that protects forests in a larger scale.

Elder members in particular, who had subsistence from the forests, emphasized nature conservation values. In one of the villages, environmental education included awareness-raising on the negative impacts of plantations, and the youth were encouraged not to seek jobs at Veracel. It was also stated that the young generation does not yet understand the full extent of problems the company has caused. Additionally, a number of young schoolteachers in other villages were greatly concerned about nature conservation issues. However, other young adults living in urban areas were more interested in connecting themselves to the plantation economy and becoming employed by Veracel. For the company, in turn, the less-educated Indians have not played any important role in terms of labor. According to one urbanized young Pataxó man, 'progress' was manifested in Veracel's presence, as he pointed out about clearcut plantations:

If the Portuguese had not come here, we would stay wild. We could not have been able to develop this land by ourselves; it would be just all forest. Veracel has brought development, but destruction too. However, the situation today is better [than it would have been without external influences]

This type of 'subaltern rhetoric' may partly originate from the long-term ostracized position of the Indians. At some point, the Pataxó no longer considered themselves Indians, since they were so marginalized by the rest of society. They have had to struggle for ethnic recognition from the state (see Carvalho, 2009). The above citation also reveals some generational division within the community in regard to Veracel.

On the other hand, many young adults in the villages were concerned over the company's harmful impact on the Pataxó community, its subsistence and culture. It was pointed out that the standard of living was generally better before Veracel. For instance, the schools were full of pupils; people's movement was free; and more sources of livelihood were available.

Our way of movement is changed. Transpassing is prohibited, traditional trails to other villages have vanished, and roads have been built.

After Veracel's arrival many residents had to move away to seek employment. The level of poverty has risen, and children's nutrition in particular was a concern, since not all necessary 
meals could be offered. Youth who stayed in their villages had few livelihood prospects, but they wished to find education and a livelihood. When people's means of traditional subsistence have essentially diminished, some alternative livelihood methods have been generated. However, this has been limited, particularly because of poverty and the low level of education. The local Pataxó culture was thoroughly transformed by a commercial process, namely ethnic tourism. In the urban areas a number of market sites sold more or less traditional handicrafts and offered cultural spectacles. The Indigenous Pataxó reserve of Jaqueira has become an ultimate showcase, visited by 7,000 tourists annually. They expected to encounter 'Indians in the wilderness', a young schoolteacher stated. The reserve featured traditional architecture (kijeme); round buildings with straw roofs, comprising of living and cultural spaces, and a school.

Velame (2010) has criticized making the Indians into 'market fetishes' and the Indigenous Pataxó reserve into a Discovery Coast 'simulation' or time travel to 16th-century Brazil. Porto Seguro municipality has, in fact, used ethnic tourism as an instrument in the national and global economic competition between cities. Local travel agencies have constructed a brand for the city as a 'Terrestrial Eden' and an image of 'pure Indians'. Considering the effect of the aforementioned pulp-related incidents on the identities of the three Indian tribes, this type of public policy is questionable and may even lead to new incidents of racism. Furthermore, urbanization and tourism - less acknowledged side effects of Veracel - have led to drug abuse and prostitution among the youth.

In the congested [and urbanized] aldeia of Coroa Vermelha the situation is becoming difficult. There is a continuous in-migration because of deforestation. Veracel and other big companies distress us. They occupy lands that we could settle and use. The future prospects for youth here do not look good. Because of disagreements and drug abuse, people become afraid of their own family members, and the families break up.

The Pataxó had a few projects among the youth, in order to improve and monitor their situation, as well as maintain cultural traditions, such as language, costumes, festivals, and dances. Some schoolteachers expressed their concern over external threats, such as tourism and big corporations, despite the social initiatives of the latter. The Pataxó had a number of rules on how to encounter tourists.

To sum up, the dual societal processes - the urban in-migration pushed by Veracel and the commercialization of Pataxó culture - are less recognized but intertwined phenomena. Like land disputes between various local actors and related racism towards the Indians, all these direct and indirect societal impacts should be better acknowledged when discussing Veracel's corporate social responsibility or irresponsibility.

\section{What did Veracel's CSR actually entail, and what were} the grassroots CSR definitions and expectations

In this chapter Veracel's social performance is scrutinized from the grassroots viewpoint: as to what corporate social initiatives and people's needs were brought up and discussed by the Pataxó themselves. What, then, constitutes responsible business practice, and what does a good relationship entail according to the Pataxó? Their responses indicated a number of expectations from the company and its CSR policy. In addition to the viewpoints of the community, I utilize my observations in the aldeias and also in personal and group discussions with the Brazilian academics. I was also interested to know about the sustainability of the initiatives, that is, how successful or sustainable they have been in the long term. In the forthcoming chapter, I also scrutinize the way the Indigenous community and social initiatives have been presented in the corporate reporting, in order to conclude to what extent corporate words matched corporate actions.

\section{Change in the corporate strategy}

First of all, it is relevant to ask: why did the company suddenly change its policy towards the local Indigenous community, with whom it previously had land disputes? For instance, in 2004, during the critical time of the pulp factory's completion, 300 Pataxó blocked the BR-101 federal highway for 19 hours in order to make the authorities aware that Veracel had planted eucalyptus on the Guaxuma village's traditional lands. In my research one cacique brought up the issue:

\section{The new strategy of social projects is a result of the fact that}

Veracel has to give back the lands to us.

Also according to the Brazilian anthropologist Sampaio, the introduction of the new corporate strategy, after 2004, was clearly related to the land question: instead of giving back the disputed lands to the Indians, the company allegedly bribed certain caciques by introducing so-called 'social programs' that included various gifts to their villages (Dr. J. Sampaio, personal communication, 2011). The Guaxuma village became involved in Veracel's social initiatives much later than other villages. While in 2006 the chief of the poor village criticized the company's actions and claims of partnership with all the Pataxó, in 2011 he said that some collaboration, albeit at a low level, had started.

\section{Indigenous land rights and economic compensation}

First of all, despite diverse opinions and needs within the villages, the most common and most insistent demand was the legal recognition of the Pataxó Indigenous Territory by Veracel and its subcontractors, and consequently, their withdrawal from the native lands. Hence it is not sufficient that the company representative(s) merely visit the villages and introduce social projects; first, the Indigenous land areas ought to be given back to the community.

The entire territory will be demarcated, and the result will show that certain parts of the plantations are located within the Indian territory. The most important thing for us is that demarcation is accomplished.

The Pataxó had not yet decided on their claims concerning the native lands occupied by Veracel, but some 'terms of responsibility' (conditions) were mentioned. It was expected that Veracel would invite all chiefs to a meeting, where the scale of economic compensation, including land restoration, would be decided. The compensation was to be shared among the villages. Moreover, as long as the Indian territory awaits registration, the chiefs hoped that international pressure to Veracel also would assist in this target. However, a smooth procedure with the company may not be that obvious when comparing it to a similar case in Espírito Santo State - an issue to be discussed later in this article.

\section{Educational, cultural and livelihood support}

The most widespread Veracel's social initiative among the 
Pataxó villages was education support. Veracel has donated 'school kits' (containing books, pens, and notebooks) to the Indigenous villages through the Municipal Education Support Program since 2008, and in 2012 the company distributed 3,050 school kits (Veracel Celulose Sustainability Report, 2012, p. 66). It was mentioned in a few villages that the company should also help in organizing school transportation. Education was generally seen as the most important issue, in addition to land rights and health; it was critical that all youth attend school.

The villagers needed support for various old and new livelihood strategies, because their living conditions and prospects were considerably weakened. Some suggested that Veracel could donate fishing equipment such as boats and nets. In one village they planned to propose fish ponds as a social project to the company, while in another village assistance in agriculture was considered more important. Support in project management skills was also mentioned.

Since many were concerned about the severe unemployment and inactivity among youth and their exodus to the urban centers, a number of interviewees suggested that Veracel should offer the youth work opportunities and also create other activities. As mentioned earlier, some youth wished to become employed by Veracel but considered their low-level education a drawback. However, in some aldeias the interviewees addressed the importance of environmental education and wished the youth would get their living elsewhere than from Veracel. As we see again in this case, the opinions among the Pataxó are not homogenous.

Veracel also offered livelihood support to a few villages, such as funding the purchase of native tree seedlings. For instance, the head village, aldeia Barra Velha, received relatively large funding for a tree nursery project (R\$26,000, or EUR 11,000$)$. Veracel also gave eucalyptus for tourism craftswork in a number of villages. Furthermore, the Pataxó received financial support for annual cultural festivals, and the village chiefs got travel support for meetings held in Brasília.

Basic services, infrastructure and house construction support Interviewees often mentioned that Veracel could help much more, especially in health and education, which were among people's most important concerns after land rights. Many aldeias did not have any health services. There was a severe lack of doctors and medicines, and equipment was outdated. Coroa Vermelha, the biggest village with 6,000 people, was served by only one doctor, who was available on weekdays and for three hours a day. The villages of Aguas Belas, Meio da Mata, and Boca da Mata faced the most difficult situation in regard to education and health care. Traditional medicines could cure ailments with a long history in the region, but not the new ones (such as HIV/AIDS, respiratory illnesses, alcoholism, and drug addiction), and in these situations people had to seek modern health care. The situation was similar to Fibria's other plant in Espírito Santo State, where the pulp factory and plantations had created new illnesses among the Indigenous groups, which could not cope with new health problems. Moreover, the state of people's health was generally weak.

Many of the villagers could not have afforded to build a basic house by themselves. In Guaxuma village the company offered to pay 5 percent of building costs. In addition, since Veracel's big trucks used local small roads to transport eucalyptus from plantations, the roads to the villages were often in poor shape. Concerning people's energy needs, one chief considered requesting Veracel's assistance in negotiating gas from Petrobras, which has a gas pump near the village. Other concerns included library and the Internet, and computers for village offices, which handle people's concerns.

The scale, sustainability and institutionalization of social initiatives Veracel has highlighted its one-year social program among the Indigenous communities (Veracel Celulose Sustainability Report, 2010, p. 56): 'The Total Protection Space' or 'Protection 'Territory' for which the company invested R\$ 240.000 (EUR 88.265), and it targeted the Pataxó and Tupinambá communities. For whatever reason, this program and its outcomes were never brought up by any of the Pataxós I met. Thereby I will analyze the program setting in the forthcoming chapter (see Box 1.). In all, the program's name, 'Protection Territory', can be regarded as misleading and even ironic, since the Pataxó struggle to reclaim their traditional territory, and the company is their most powerful opponent.

Based on my study, the scale of Veracel's support was minimal, particularly for an affluent multinational company. The result became even more striking during my fieldwork, when news emerged of Fibria's and Stora Enso's huge business profits. A Pataxó chief added:

During the last two years Veracel has mainly organized school kits, which is not much compared to the overall destruction it has caused. The municipalities have the biggest economic profit from Veracel's presence here - for us there remains only a package of books!

Equality question between the company and the community in terms of distribution of economic benefits or royalties was not mentioned by the interviewees. According to the chiefs, the social initiative practices were not actually institutionalized with Veracel. Nor did the villages and chiefs have direct con tacts or discussions with the company management, but with an ombudsman.

The results of Veracel's social initiatives highlight the arbitrariness of the company's stakeholder relations. The aforementioned tree nursery case illustrates one of the core problems in funding community projects without supporting activities, namely the capacity-building to run a project. So Veracel do nated EUR 11,000 for a tree nursery initiative in Barra Velha village. However, the project did not last:

The reason for the failure was within ourselves. Thirty people were involved, and we had mutual debts and quarrels, so the group broke up.

Here the chief took the blame and did not criticize the company in any way. He just hoped that Veracel could continue its support and give assistance in accounting and other project management skills for new initiatives in the future. In another village, Veracel had donated a school car, but people could not afford to maintain it; hence it was no longer used.

My overall personal observation in the villages was that the residents were initially quite wary of discussing their relationship to Veracel openly. For instance, this could be noticed between the lines, through nonverbal communication, so people's concerns were probably not always directly expressed. The powerful corporation's existence thus addressed the ostracized societal position of the Indigenous community in Brazil in general. The Pataxó were obviously afraid to lose even small benefits, as one community member revealed:

We are aware how small the company's support is - it could afford to do much more. But we are weak and do not have the 
power to demand bigger amounts of assistance. Even a small bit makes us happy.

\section{Approach to the community}

When the company arrived, they did not come to talk to us. It has gradually started to open social programs, but we are not satisfied with the level of openness. They should really listen to us.

During the initial stages of a new investment, there was not enough communication with people. In some villages it was wished that Veracel's upper management would have a discussion with them and not merely visit the local governments. The main communication channel in the Pataxó-Veracel relationship seemed to be founded on the ombudsman system; a company representative received a 'wishlist' on a regular basis, particularly from certain villages. The chiefs with less communication with Veracel expressed a need for a honest, "genuine dialogue', meaning better authenticity its stakeholder relations.

It also became apparent that Veracel's social initiatives were not equally targeted. There were arguments that the company had divided the Pataxó community, because some villages got more assistance than others. A few villages were visited by the company representative more frequently and consequently received more support. Some members regarded this as merely a malevolent company tactic in which the company attempted to intentionally divide the Pataxó.

I can't criticize the company in any way. What we need we get.

We have a good partnership [sic] because the company assists us.

We feel as if we are divided: some groups get more than others.

Dialogue is difficult because even though the company representatives arrived here, listened to our complaints and saw our problems, they did not act - even though we tried to present the issues as clearly as possible. Veracel should become more humble and listen to our needs.

It happens here that the villages that do not have a plantation within their territory start to stand up for the pulp companies. Even within families, problems and conflicts arise when family members live in different places.

Hence a rather common opinion was that Veracel should aproach each village on an equal basis concerning discussions, decision-making, and social initiatives.

While the most of the caciques interviewed had defined various community needs, there were some exceptions. One chief had actually minimized his village's relations with Veracel because of its overall negative impact; recognition of the Indigenous territory was his only requirement. He also wanted to guarantee the continuation of cultural customs, as well as conservation of the remaining natural forests. In this case, a CSR definition addresses that a company should respect their position as Indigenous Peoples and refrain from any interference in their affairs.

Field research results juxtaposed with corporate performance and reporting
As demonstrated in the Brazilian case study, we can discern corporate impact in terms of pulp production and CSR performance. In this chapter I assess Veracel's social initiatives and local stakeholder relations, all of which are juxtaposed with my research findings. Since in Veracel's reports stakeholder management is discussed less than in those of the two partner companies, statements from Fibria/Aracruz and Stora Enso sustainability and responsibility reports are analyzed here. Viewpoints from Stora Enso's Sustainability Communications group in Finland are also included. In addition, the less-heard insights of the Brazilian academia and other experts are presented; namely the anthropologists from the Federal University of Bahia (UFBA), representing the Research Program on Indigenous Peoples of the Northeastern Brazil (PINEB). The anthropologists considered the continuous growth of massive eucalyptus plantations very problematic in Bahia and Espírito Santo (personal communication, Dr. J.A. Sampaio, Professor M.R. de Carvalho, and Researcher S. Miranda, 2011).

\section{The reference case: massive impacts on local livelihoods}

In Espírito Santo State, 40 year land dispute between the Indians and Fibria/Aracruz became to an end in 2007, when Brazil's minister of justice signed an administrative ruling to declare the disputed area $(11,000 \mathrm{ha})$ claimed by the Indians as an Indigenous territory. As a result, Fibria/Aracruz was ordered to withdraw from this land and pay the ethno-environmental study and compensation for the Indians. Since Fibria/Aracruz is also a co-owner in Veracel, the researchers listed many similarities in both cases - corporate history cannot be ignored. In its sustainability report, Fibria/Aracruz twisted the historical and other facts on what actually happened in Espírito Santo. During the prolonged land dispute, the company used violence multiple times against the unarmed Indians, as well as questioned and undermined their cultural identity. In the 1960s Aracruz destroyed Indigenous villages, evicted people from their homes, and logged primary rainforest from the region. Since then, the Indigenous protests have been suffocated by using force. In 2005-2006, the Tupinikim leaders were wounded by rubber bullets and illegal arrests by security forces. In addition, the company has used quasi-scientific reports by employing nonindependent anthropologists to, for instance, undermine the identity of the Tupinikim. (Myllylä, 2010; Myllylä and Takala, 2011.) Yet the corporate reporting presents a very different historical narrative: ... "the company's previous occupation of the land had been in good faith" (Fibria, 2011, 80-81).

Moreover, during the heated land dispute incidents in Espírito Santo State, Fibria/Aracruz still enjoyed membership within the United Nations Global Compact Initiative, whose basic principles include respect for the Indigenous Peoples' rights. On the other hand, in 2010 Veracel was expelled from the Global Compact Initiative, because the company failed to communicate progress by the required deadline (United Nations Global Compact, 2011), unbeknownst to Stora Enso Sustainability Communications group (personal communication, 2011). But disturbingly, companies can join various global CSR or good governance regimes and institutions, and even receive international awards for good CSR, despite having severe problems with local populations. Information from the local stakeholder level does not reach these types of global CSR institutions.

Considering that traditional communities often live off the land, the term 'livelihood' intertwines economic, social, and environmental issues in the contexts of the global South. Experiences from the Espírito Santo reference case offer scientific information on the ultimate, long-term impacts of eucalyptus 
plantations on local livelihoods. An extensive study was completed by a Brazilian multidisciplinary research group to assess corporate impacts, and the results were staggering (see Table 1). Fibria/Aracruz had to pay nearly R $\$ 4$ million (EUR 1.5 million) compensation to the Tupinikim/Guaraní. However, the sum is far from close to covering the damage the company has caused. The researchers estimated that the compensation should be at least 20 times more, thereby the actual cost is at least R\$ 80 million (EUR 30.6 million).

Fibria does not want to hear anything about the Tupinikim anymore (Sampaio, personal communication, 2011).

It is about capitalist logic: there are risks, but the profits are much bigger (Carvalho, personal communication, 2011).

The empirical findings of this study indicate that pulp production has also had a considerable social, economic, cultural, and environmental impact on the Indigenous community in Bahia State. What is noticeable is the fact that pulp production is a highly male-dominated and a mechanized sector; it requires trained employees, and does not recruit Indigenous Peoples, or rarely employs them. Veracel has not alleviated unemployment by hiring the Pataxó. In all, companies should support economic, social, cultural, and biological diversity among the host communities and their environments. In the current production model, massive monoculture development is dominating in the region.

The UFBA scholars addressed environmental degradation affecting people's nutrition: an external actor such as Veracel can damage the quality of food and potable water. As a result, people's health in the aldeias is generally weak (Sampaio, personal communication, 2011).

Table 1. The reference case: Ultimate impacts of eucalyptus plantations on the Tupinikim/Guaraní Indigenous territory in Espírito Santo State. This report was carried out by a Brazilian multidisciplinary research team, representing agronomy, biology, cartography, anthropology, and forestry.
Veracel's biggest impact on the Pataxó is the fact that plantations are located too close to the Indigenous lands, and the soil is destroyed. Even if a new plantation has not yet been established, the land is still neglected. Veracel is like a wound that does not become cured but spreads: the problem is the continuous expansion of plantations, which not only affects the Indigenous groups but also the Afro-Brazilian Quilombos and small rural farmers (anonymous representative of Brazil's Federal Public Ministry, personal communication, 2011).

The 'terra nullius' and whitewashing strategies

At least some parts of Veracel's initial land acquisition approach in Bahia seem to rely on the ancient Roman law 'terra nullius', referring to 'nobody's land' or 'empty land' (cf. Australian Indigenous politics, in Crawley and Sinclair, 2003):

In a short time, the company occupied vast land areas in a legal way and claimed that they were not aware of the Indigenous Peoples' territories - the company actually pushed people away and created poor areas (Sampaio, personal communication, 2011).

Brazil has a slow and bureaucratic legal system, which lacks the capacity to assess the impacts of MNCs (Sampaio, personal communication, 2011). As discussed earlier, although the land rights of Indigenous Peoples are recognized in the Brazilian Constitution, in practice the situation is complicated, because the federal government and FUNAI have diverse opinions on Indigenous issues. As a result, the legal basis directing the role and impacts of MNCs is very ambiguous. The registration of the Pataxó Indigenous Territory has been arduous, and Veracel's withdrawal is not yet clear. It was feared that instead of payment to the Pataxó, Veracel will most probably claim com-

\footnotetext{
1. Environmental impacts

-Extensive soil impoverishment and erosion.

- Pollution of water systems.

-Destruction of original flora and fauna.

- Of the remaining natural forests, 15 percent degraded (during the 1960s Atlantic Rainforest was extensively logged by Aracruz)

-The sewer system in the entire area - of Aracruz and the Indians - was never taken care of and thus caused a widespread contamination.

2. Socio-cultural and livelihood impacts

-During the 40-year existence of Aracruz Celulose, the Indigenous populations have become isolated and abandoned.

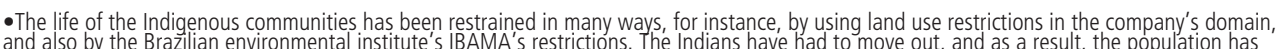
concentrated and to cities in search for employment.

-During the existence of the neighboring company and its plantations, the livelihoods of the Indians have drastically changed, consequently due to decreased land production capacity. The youth were better educated than before, but he older generation sought to return to its previous way of life after the Indigenous territory's restoration, for instance, by using rotation crops. In principle, this would be easible, but there were at leas know-how on agricultural methods has survived.

Even though much of the area was clear-cut land, consisting of a huge field of eucalyptus stumps after the company withdrew, the Indigenous territory area was not totally destroyed. Some better sites remained, in which forests and agricultural lands were in rather good condition while others needed help. Zoning was to identify areas of different condition and their needs. Eucalyptus was found to be a tricky plant, since after logging it started to grow again. All in all, the report shows that recuperation is possible, but it will be a complex process, requiring huge investments. According to the agreement betwe 1.5 million) to the Indians. 1.5 milion Ac the 30.6 million)

Source: Sampaio, personal communication, 2011; see Ferreira, et al., 2010.
} 
pensation to itself from the government - like Fibria/Aracruz did in Espírito Santo. There the company took "the role of a poor family that is being paid to move out" (ibid.). Veracel may also justify its compensation claims that it has increased the land value in the region. The company has not expressed any sign of voluntary withdrawal from the Indigenous territory. (Ibid.). In the interviews the Pataxó pointed out that FUNAI has hesitated to finalize the registration, because its staff is afraid of possible violence by the fazendeiros.

Legal CSR principles are mandatory, depending on the host country's legislation. Problematic situations emerge when the national and international, or/and partners of two nations' judicial systems and business practices differ much from each other. In the global South, the standards are often lower. Business decisions in ambiguous situations demand good ethical backbone, since the company management has to decide how to deal with them from the beginning. It should not simply carry out the minimum legally required corporate responsibilities; instead it should be a forerunner; 'do more', and take substantive voluntary steps. Stora Enso has apparently relied greatly on the leadership style of its Brazilian partner, whose occasional unethical actions towards local communities have caused 'surprises' for Stora Enso,

According to a Brazilian environmental lawyer working for the non-governmental organization SOS Mata Atlântica, firms that have a bad record or fail to provide an acceptable Environmental Impact Assessment (EIA) report often change their names and attempt to initiate business elsewhere in the country (Camargo, personal communication, 2004; on the complexities of the Brazilian EIA, see Kirchhoff, 2006; Biller, 1998). The Brazilian researchers were not surprised that Aracruz changed its name to Fibria after its reputation was badly tarnished in Espírito Santo. The company is apparently striving for a more positive, greener, and people-friendly image in order to get rid of its negative track record. This is indicated in Fibria's Sustainability Report 2011 (p. 74):

A good relationship with the residents of communities located in the vicinity of Fibria's operations is critical to the company's performance. Since it was founded, in 2009 [sic], it has invested in engagement and socioenvironmental projects aimed at supporting social inclusion and improved quality of life in these communities.

Veracel's stakeholder mapping and 'engagement' with the Pataxo Starting from the corporate establishing phase, various stakeholder 'consultations' or public hearings are procedures often required by the host country, for instance, in the event of an Environmental Impact Assessment (EIA). But what generally emerges is a top-down, corporate-led action in which local communities are relegated to being mere listeners. In addition to mistrusting corporations with a negative track record, the Brazilians rely little on authorities, and therefore public hearings also may not attract participants. In some instances, companies have intentionally organized public hearings in such a way that locals have difficulty in participating. The Espírito Santo case exemplifies that host communities and their supporting civil society organizations may lose trust in the corporation, and reject any dialogue, if corporate actions do not match its words. Hence a lack of trust represents a serious power distance between the people and institutions in the Brazilian society (cf. Hofstede, et al., 2010).

As is typical of multinational companies, Veracel, Fibria/ Aracruz, and Stora Enso have attempted to position themselves outside of Brazil's socio-political issues, but this has become increasingly difficult for them. Similarly, they perceive and identify corporate impact very narrowly:

Fibria maintains good relations with most of the communities neighboring its operations. However, there are some unresolved conflicts with certain communities in the poorest regions of the north of Espírito Santo and the south of Bahia, stemming from problems that are often unrelated to the company and beyond the management's capacity to resolve, regardless of its good intentions ... Some communities merit special attention from the company, which has been developing specific projects for social inclusion, often with the participation of government bodies and independent socio-environmental entities. (Fibria Sustainability Report 2011, p. 80.)

In particular, indirect consequences, or 'chain reactions' of pulp production in Brazilian society are not recognized. But establishing intensive business in the poorest regions of Brazil automatically creates a variety of conflicts of interest with the local population, who struggle to keep their livelihoods and scarce resources. Idahosa (2002) points out that firms do not usually appear willing to consider the possibility that their operations even if well intentioned - might be contributing to a deterioration in the situation at the community level, and that as a result, they should not be operating there on moral grounds.

However, by acknowledging and developing corporate social responsibilities, the companies also admit their roles and duties in the society, including the 'specific communities':

This refers to Indian and black communities, traditional fishing settlements and those of landless rural workers that are directly or indirectly related to the company's activities in the region. Several interviewees said that they had had problems in the past, particularly in regard to land ownership and eucalyptus cultivation in areas occupied by traditional communities, but that nowadays it is dialogue that prevails. (Fibria Sustainability Report, 2011, p. 90.)

Also Stora Enso uses a positive discourse and emphasizes Veracel's harmonious situation with all of the Indigenous groups:

In Brazil, our joint venture Veracel maintains good relations with the area's 17 Pataxó and Tupinambás communities, and supports programs designed to strengthen their cultural identity. (Stora Enso Global Responsibility Report, 2012, p. 29.)

But as my research findings illuminate, the actual situation is not that harmonious as the reports aim to offer to the public. In corporate stakeholder mapping, from establishing phase to execution of social initiatives, Veracel has used very divisive approach or tactics. Initially, Veracel allegedly bribed certain caciques by introducing social programs that included gifts to these villages; particularly those located further from the plantations and thus having less interest conflicts with the company. Thus Veracel has failed to approach the heterogeneity within the Pataxó in an equal manner by favoring certain groups and strengthening collaboration with them. In spite of the unequal and divisive approach, the companies have tended to maintain a public image that their joint venture has a partnership with the entire Pataxó community (e.g., Veracel Celulose Sustainability Report 2010, p. 67). The Brazilian research group stated that the positive discourse by the firms represents an interesting phenomenon, but it cannot continue forever as a business strat- 
egy (personal communication, 2011).

In recent years, Fibria/Ararcruz has attempted to develop corporate stakeholder relationship management, including participative programs, e-journals, radio, and 'EcoJournals' for schools to increase communication with the local communities throughout the country. These activities were not mentioned among the Pataxó in my study. Furthermore, the pulp companies have not only assumed the role of protectors of nature but also sought to present themselves as environmental educators for local communities (see e.g. Veracel Celulose Sustainability Report 2011, p. 89; Stora Enso Global Responsibility Report 2012, p. 89). Stora Enso Sustainability Communications group in Finland addressed that the company has an important regional role by protecting nature with Veracel's nature reserve2, Atlantic Forest Program, and the communities' tree nurseries (personal communication, 2011). Considering the huge eucalyptus plantations and their massive impact on local ecologies, these new green corporate roles are questionable. In addition, Fibria/Aracruz has made a 'Relationship model' for communicating with neighboring communities (Fibria Sustainability Report 2011, pp. 71-77). In the model's 'Engagement' approach it is stated:

Fibria assumes the role of local development partner and seeks to understand the communities, while engaging them in the company's activities and decision-making processes. The Engagement model takes place in those communities most impacted by Fibria's operations.

It is not clear what is meant by 'decision-making processes' and at what level they would take place. The model's adaptation in regard to Indigenous groups such as the Pataxó was not mentioned in the corporate reports. Veracel has often left out the communities most impacted by its operations. Concerning the employment question, Fibria/Aracruz openly admits that the change in its policy from direct employment to outsourcing prompted one of the major criticisms made by the communities in Espírito Santo and Bahia (ibid., p. 89).

Land rights of local communities are little discussed in the responsibility and sustainability reports. According to the Stora Enso Global Sustainability Report 2012, the company's eucalyptus plantation projects with intensive land use need to ensure that the rights of the Indigenous communities are fully respected. The company denied any problems:

We recognize the unique economic and cultural needs of indigenous peoples, their traditional uses of forests, and their legitimate rights to their traditional lands [sic]. We strive to en sure that our operations do not violate the rights of indigenous peoples who live near our operations. During 2012 we were not involved in any instances of violation of indigenous peoples rights. (Stora Enso Global Sustainability Report 2012, p. 29.)

It is notable that in Veracel's sustainability reports there is no clear recognition of the Pataxó Indigenous Territory question. On the contrary, the company covers up land disputes and inequalities related to its presence:

All the areas legally recognized and indigenous communities are fully respected by the Company and are treated equally. Veracel does not have plantations, whether own, or in the Forest Producer Program, located in marked indigenous lands. (Veracel Celulose Sustainability Report 2011, p. 103).
However, in the company newsletter the situation is described differently:

Regardless of the legal status of the indigenous lands in the municipalities where Veracel operates, the company is aware, respects and contributes for indigenous causes (Veracel

News, 2011).

What is notable is that Veracel has never taken any any active stance on the land question but has left the situation unresolved. In this regard, Stora Enso's Global Responsibility Report 2012, for instace, is only partly accurate and leaves out some important facts in two areas. First, land disputes and stakeholders' criticism in China are discussed at length in the report, while the situation of the Pataxó Indigenous Territory in Brazil is not mentioned at all. This is also the case for Stora Enso's Global Responsibility Web site, which was given the European Excellence Award in 2010. Stora Enso's Sustainability Communications group stated that they were not at all aware of the Pataxó Indigenous Territory question (personal communication, 2011), which may explain the lacking information. Nor were they aware of the tarnished reputation of Stora Enso's partner. This, in turn, raises a question of institutional memory and its sustainability: in both Finland and Brazil the managers in the CSR field change relatively often. Second, although Stora Enso was not directly involved in violent encounters with the Indigenous groups, Veracel affects people's well-being and human rights in diverse ways. Stora Enso has recognized the need to adopt new approaches to its local stakeholders, although the results have not been convincing and sustainable so far. In 2012 Stora Enso appointed acclaimed human rights expert, who after just 5 months with the company resigned due to disagreeing views on sustainable development and human rights. In the interview with the Sustainability Communications group (2011), they mentioned the need to increase knowledge and openness in the corporate culture of Veracel. According to the Stora Enso Global Responsibility Report 2012 (p.5),

As Stora Enso has tree plantations in densely populated areas in growth markets, this is a fundamental issue for us. We are actively looking into innovative ways to use land, improve the efficiency of forest use, and share value with local communities. In many cases this means working with local communities to find new land use solutions, and create new local business opportunities. Most of all, this means maintaining constant dialogues with local stakeholders to find ways for everyone to benefit. At Stora Enso we must be truly open to new initiatives, and prepared to rethink our business.

The sustainability reports list a number of social initiatives that have taken place in recent years, but it is difficult to ascertain what the impact of activities has been, since the outcomes are often stated in a very shallow manner. Hence the results, or actions, are mainly listed in impressive numbers:

In 2011, several environmental responsibility programs and actions undertaken by Fibria, including healthcare, education and training, environmental issues, economic and socio-cultural development, reached approximately 150 thousand people (Fibria Sustainability Report 2011, p. 77).

Merely listing activities does not represent a sufficient criterion of good CSR performance. Participation and training, for instance, are not results but mere activities; what matters 
is their impact. Certain evaluation questions can be asked; for instance, how did the training benefit the participants' livelihoods, and how relevant was it for the locals and their needs? (See Box 1 below)

Furthermore, a disturbing trend can be seen in corporate reporting, involving the use of local people as speakers or faces for the company. 'Content' Indigenous members are named and quoted (see e.g., Veracel Celulose Sustainability Report 2012, p. 71). Another is to publish pictures of the Indigenous and other traditional communities' members (e.g. Stora Enso, 2012, cover page). Using and publishing photos of the children and youth is particularly disturbing (see Veracel Celulose Sustainability Report 2010, p. 19, 56-57). This style, designed to appeal to the public, indicates a new strategy in reporting, which could have been influenced by some anthropologists working for the companies.

According to the 2010 sustainability report, Veracel donated native tree seedlings to two villages (p. 57). However, this social initiative and its results were not brought up by the villagers themselves during my interviews. The sustainability report also states that "in 2009, in partnership with FUNAI, Veracel also supported the construction of an indigenous school in the Jaqueira Reserve ... where 65 families live" (p. 57, author's emphasis). In 2012 the company "delivered the material for five buildings within the indigenous schools, including classrooms, cultural centers and a children's park" (Veracel Celulose Sustainability
Report 2012, p. 66). As I observed during my 2011 fieldwork, Veracel had merely donated cheap or basically free materials to the school located in the Jaqueira Reserve: eucalyptus trunks and piaçava leaves for a traditional kijeme round building, and a small toilet. For this modest donation, the company got its name placed in the list of donors on the billboard beside the road to the aldeia. It was a common sight all around the region, and it represents one of the company's tactics to publicize its partnership with the communities. The company allegedly donated a police car to the municipality, which is ethically questionable and contradictory - in comparison to social projects in the villages - since the police are usually involved in evicting the Indians from their traditional lands, which have been overtaken by fazendeiros. In all, Fibria/Aracruz and Veracel have a tendency to exaggerate their philanthropy results by offering only positive, successful descriptions, instead of more objective and self-reflective analyses expressing organizational learning. This can be seen as a common problem for corporate reporting and public presentation in general, despite serving the interests of shareholders and international business circles.

Among the main results were also mentioned partnerships with universities and NGOs. This is a legitimate result, but it should be stated transparently whether the company funded these actors, whether it influenced the research topics in any way, what type of partnership it was, and who exactly was involved. It should not be forgotten that, in recent years, Aracruz

Box 1. "Communities are given a Total Protection Space".

Veracel has highlighted one social program among the Indigenous communities (Veracel Celulose Sustainability Report, 2010, p. 56): 'The Total Protection Space' for which the company invested R\$240.000 (EUR 88.265). This one-year (2010-2011) public-awareness campaign focused on the 'violence risks' ('personal and social at-risk situation', e.g., abuse and sexual exploitation) experienced by the Indigenous Peoples and targeted five Pataxó villages and one Tupinambá village. The government of Bahia State, FUNAl, and NGOs, among many other actors, participated in the program. The program, focusing on child and teenage protection, was run by an NGO, Instituto Tribos Jovens. The campaign did not happen at the village level; instead, a number of education seminars were organized around the municipalities. The project raises many questions from the viewpoints of development studies and international development concerning the agency, project goals, transparency, processes, and impact on the communities. It is striking that although the program focused on violence experienced by the Indigenous Peoples, it did not include those villages that had faced conflicts and racism from the actors related to Veracel's presence and land acquisition.

Since the area is highly urbanized and has a great influx of tourists, these populations are culturally under pressure and at a greater risk of suffering violence and sexual abuse. To counter this reality Veracel, in partnership with public offices and native community representatives, has sponsored and supported programs to rescue their traditional way of life and citizen rights, one of which is the 'Total Protection Space'. (Veracel Celulose Sustainability Report, 2010, p. 56.)

Hence aldeias that already had a better relationship with the company participated in the program. It seemingly bypassed perhaps the most critical sources of human insecurity - discrimination, violence, prostitution, and the use of drugs - that were all at least partly caused by Veracel's plantations and the related repressive actors. The concentration of the Indians in urban centers due to the loss of livelihoods did not emerge in the program setting. By disregarding Veracel's negative impact on the communities, the whole program jeopardizes its credibility and objectivity. In addition, the program outcomes were again stated only quantitatively: "150 persons trained in a month: a total of 2,875 beneficiaries: In addition, the program outcomes were again stated only quantitatively: "150 persons trained in a month: a total of 2,875 beneficiaries;
1,981 attention and orientation sessions; and 894 leaders trained" - as if these impressive numbers explain the 'achieved results' and justify a 1,981 attention and orientation sessions; and 894 leaders trained" - as if these impressive numbers explain the 'achieved results' and justify a
huge amount of funding. No in-depth impacts of training were clearly assessed. Only a few results were explicitly mentioned, for instance, "10 percent increase in the number of reports regarding violence against children and adolescents"; while the rest were expressed ambiguously: "... strengthened social fabric and human capital; and differential in public policies of Bahia State and Brazil". What do these actually mean; how do they manifest in practice? Despite my request for more detailed information on the program results and impacts, and the use of funding among diverse actors, the NGO representative just referred me to the brochure summarizing the above results (Tribos Jovens, personal communication, 2012).

The program was based on educational and research activities such as "Integral Protection Space (i.e., mapping risky areas); Attention; Training Leadership; Campaign; Network Strengthening; Participative Management; Research - Situation of Violence; Multiethnic Team; Assessment and Monitoring System". This type of ambiguous program setting directs attention not only to the impact of these activities, but also to the allocation transparency of a very large amount of funds for a one-year public-awareness campaign program, in Brazil. So how much was actually spent for experts and consultants? What was done with the funds, which were very large compared to the results achieved and the community impact? In development project a common problem is that a disproportionate amount of funding is spent on experts and consultants, while only a small frapment project a common problem is that a disproportionate amount of funding is spent on experts and consultants, while only a small fraction actually benefits the target group. It raises further questions about community benefits, ownership, and transparency. In other words, could the EUR 88.265 donation - for just a one-year initiative - have been better used for the Indigenous communities? Did the Pataxo villages participate - and on equal terms - in the prioritization of assistance and hence the selection of this particular topic? Why did on certain villages participate? My research data indicates very different types of needs among the Pataxo than indicated in the above project. The youth problematic in urban areas was brought up in both, but in my study it was more linked to Veracel's impact as a consequence of losin livelihood opportunities. In addition, the personal security issue was primarily mentioned in regard to the actors organizing land reserves for Veracel. To sum up: when a firm is a main donor, it more or less affects the topic and approach of the program, and thus the participants find it difficult to make criticisms targeted at the donor itself. 
offered funding for the Espírito Santo State University staff and students to carry out research favorable to the company. This sparked some resistance on the university campus. In addition, the national-level civil society movement against eucalyptus plantations - the Brazilian Network against the Green Desert - has also involved numerous Brazilian academics, particularly social scientists.

Based on the experiences in various local development initiatives of the global South, material assistance has proved to be a problematic tool. It not only creates a dependency relationship between the donor and the community but also generates inequality within the community. In addition, disregarding property maintenance is a common deficiency in many philanthropic endeavors. Veracel is no exception, and hence it has room for improvement in the approach and sustainability of its social initiatives. For instance, the school car and the tree nursery cases were not successful. In the former, maintenance costs were not taken into account. In the latter, the community members lacked the capacity to run such a project, and internal powerrelated problems also hindered the success of the initiative.

In all, the following questions can be raised in corporate performance and reporting: How are the communities identified and their corporate relationships presented? Which social initiatives are suggested, and by whom? Who participates? Are the projects analyzed and by whom; what is exposed and emphasized, and what is left out or hidden? How is societal credibility sought? Is the report realistic, understandable, and accessible to the host community? Overall, does the report seek objectivity, or is it merely for 'greenwashing'?

Philanthropy may change entire community dynamics, as seen here, when conflicts and other power struggles arise not only between the aldeias, but also within (single) families. Trying to adopt new practices - such as administering increasing funds in projects - can cause tensions within the local community. These consequences are typical of international development situations between the donors and the low-income societies in the global South. It was also brought up in the village interviews that Veracel's lopsided approach to the villages represents a deliberate business tactic. The argument is supported by international background literature, according to which large oil corporations in particular and other external actors can knowingly use social projects as tactics to cause divisions in the host communities and hence weaken resistance movements (see Haller, et al., 2007; Eweje, 2007). In cultural policy, this phenomenon is called guided governance. Philanthropy also entails a serious dilemma when corporations fund or manage capacity-building efforts, they may wield, or be suspected of wielding, undue influence on the community. This problem reinforces the benefit of involving respected and independent third parties in capacity-building initiatives (Murphy and Arenas, 2010). Finding a competent, independent third party is a challenging task, since local governments can be oppressive towards the traditional communities and/or rely on corrupt practices and actors, which may endanger the basis of social initiatives. Non-governmental organizations may have goals that do not serve the community needs, and NGOs may not be accountable to any institution, or their actions are not assessed (see e.g. Myllylä, 1998, Rajak, 2011, p. 191). Some NGOs are only nominal and have been established by persons closely affiliated with a corporation. Hence the minimum that can be recommended is that i) the third party should have a good track record as well as experience in community work, ii) the community's priorities should have weight, and community members should be taken into account equally, and iii) the impact, ownership and sustainability of the social initiatives ought to be carefully assessed.

Social disintegration among the Pataxó has obviously caused fractures in their resistance movement against Veracel since its establishment:

Veracel has managed to take over the Pataxó, as Aracruz did

in Espírito Santo for the Tupinikim in the 1980s and 1990s

(Sampaio, personal communication, 2011).

Although it may seem that the Pataxó resistance movement against Veracel has ceased along with corporate philanthropy, several Indigenous movements have emerged to draw the attention of FUNAI, the National Institute for Colonization and Agrarian Reform, and Veracel toward the registration of the Indigenous land and local livelihood needs. For instance, in 2013, 70 families from several Pataxó villages occupied Veracel's ranch, on which eucalyptus was planted. Among others, Barra Velha, which is the oldest aldeia and has received a large part of Veracel's assistance, also participated in the occupation. These incidents demonstrate that since the company has not respected Indigenous rights, it also lacks people's trust and acceptance, despite its attempts to project a public image of a harmonious relationship and increasing philanthropic support. Thus, the company's attempts to offer ever more philanthropic assistance still do not resolve the most fundamental issues related to the demarcation of the entire Indigenous territory and the question of larger and equal community benefits.

To sum up, for the Pataxó Indians, Veracel does not actually represent anything new in the region. They and their forefathers have experienced similar situations on many occasions:

Concerning the Pataxó resistance movement, we should bear in mind the historical perspective of this Indigenous group and its numerous struggles, and their effects on the Pataxó identities. For 100 years the Pataxó were isolated, until the 1950s, when big companies came and the Monte Pascoal National Park was also established. The Indians have struggled against capitalism for over 50 years; before this, they fought for their right to education and health services, all which have both united and divided them to this day. It has been a very long process, in which the community has both converged and fragmented in fighting against external forces. Eucalyptus plantations simply represent a continuation of this history. Something good has also appeared alongside Veracel: the rights of the Indians have been brought up for public discussion. (UFBA Research group, personal communication, 2011.)

\section{A Concentric CSR Roadmap Model}

The goal of this study was to understand the corporate impacts and the CSR expectations from the Indigenous perspective to deconstruct the ambiguous CSR concept and reconstruct it from the grassroots. By using the Grounded Theory approach in an adaptive manner, a three-dimensional, Concentric CSR Roadmap Model was developed for corporate relations with the local community stakeholders in the global South context. A data-based inductive method was used, combined with a exploratory case from Brazil. Three main hierarchic CSR responsibilities (binding, ethical, and philanthropic) were identified, with 22 conceptual categories or principles, and 49 subprinciples. The field data was supported by the extant literature in the later stages of the research process. The typical CSR categories - legal, ethical, and philanthropic principles (cf. Carroll, 1991 ) - were considered, although in a different way than the extant theoretical literature. First, I named three main catego- 
ries: 'binding', 'ethical', and 'philanthropic' principles. Second, the GT approach brought up an observation that these three main categories should be understood and used hierarchically, rather than treated as equal principles. Third, my data offer new meanings for their contents, as discussed below.

The Brazilian case study and the Indians' opinions, especially in territorial issues, reflect well on the Indigenous People's rights of ILO Convention No. 169 (see articles 25, 26, 29, and 40). This is also the case concerning the issue of self-determination, stated in the United Nations Declaration on the Rights of Indigenous Peoples (2008). Hence Veracel's social performance can be criticized on multiple grounds; however, the company sees its position very differently (e.g., Veracel Celulose Sustainability Report 2010, p. 67):

There were no cases of violation of native population's rights recorded. The relationship between the Company and these traditional communities has been close to a partnership.

Compared to the extant literature, my model presents a new approach to CSR criteria when guiding and assessing corporate performance of the firms establishing themselves in the global South. Besides contributing to the theoretical discussions, the Concentric CSR Roadmap Model is meant for a mainstreaming code of conduct to guide and assess corporate performance in local stakeholder relations. The model specifies a multitude of societal circumstances and situations that corporations are most likely to encounter with the 'external' stakeholders - the host communities. Concurrently, the chosen business decisions concerning these situations determine whether the corporate impact on the host community is positive, neutral, or negative - or as my data shows, all of the above, showing that diverse corporate approaches can be mutually contradictory. Furthermore, there is a need to further develop the practical-level indicators for the CSR criteria.

The model is presented in two stages: as a table, and as a concentric model (see Table 2, p.46 and Figure 1, p.47). The outer circle, i.e., binding responsibilities are described here by 'in which frames' questions, while the middle circle of ethical responsibilities refer to how something is done. In the inner circle, philanthropic responsibilities, it is basically a question of what is done, and it is primarily regarded as government's sphere of responsibility. Cultural context in the global South forms the model's 'meta-framework'

Presenting the model as a hierarchical, concentric ringroad formation has several meanings (see Figure 1). First, the most urgent and binding issues have to be tackled first: in the global South, land and its resources are particularly important for people's livelihoods. When the land ownership conditions are ambiguous and disputed (not to mention when there are protracted legal battles), this should be taken as a strong warning sign and risk for the business - even when the host government welcomes new investment. In the era of social media, it does not take much to put a company into the global spotlight and tarnish its reputation.

My model points up the fact that if the most crucial local needs are not first solved in the outer circles, actions at other levels may merely cover up more urgent and sensitive issues in the corporation's stakeholder relationship. To cite some examples, Veracel should have, first of all, clarified the disputed boundaries of the Indigenous territory before starting philanthropic activities in the Pataxó villages. And even when the land disputes emerged, as well as accusations of violating protected forest areas, the company did not consider withdrawing, but kept its position. Veracel's corporate practices have been divisive in regard to the identification of stakeholders and their needs. The company may have operated for the most part within the minimal legal boundaries, but many of its acts raise critical ethical questions. Hence it is argued that the binding and ethical responsibilities should precede the philantropic ones. They are considered subordinate to the higher responsibilities guiding the scope and quality of impacts: before planning a philantropic initiative, both its binding and ethical entailments ought to be assessed, and business decisions and strategies should be made accordingly. However, the numbered principles are not to be considered hierarchically within the each circle.

The 22 principles - the 'traffic lights'- are guiding and alerting nodes where a company has to seriously assess its business decisions and strategies. To disregard any of the binding principles can easily spark a civil society movement to rectify the situation, but then it may be too late for the company and its brand reputation. While the model is composed of a set of guidelines and standards for business decisions and strategies, it is equally meant to be a protective shield for the host communities with few resources to defend their rights when encountering powerful corporations. Hence the ringroad structure contains an ethical, community-protecting purpose: there should not be unrestricted access and impact to the host communities' livelihoods and cultures by external actors, such as multinational corporations. That is, the corporate-community relationship should be based on more equal principles compared to the previous business-as-usual situations.

The model may help to reduce power imbalances in firms relations to local communities and also to pinpoint the ambiguous situations in which the corporation attempts to gain local acceptability by questionable means and aims. To sum up, the model is based on the idea that corporations require wider and deeper cultural knowledge of the societies before establishing a position in the global South. In addition, the model may be useful for the corporate-stakeholder relationships in the global North; for instance, concerning the recent cases in which multinational mining or oil industries operate in the Arctic region, and the local communities have been affected. In addition, the model can be expanded to comprise other stakeholders, as an expanding web of relevant actors at diverse geographical levels.

\section{Conclusions}

This article has demonstrated societal challenges that an MNC faces when establishing itself in the global South. The findings from Brazil identified a number of research gaps in the extant literature, which this paper attempts to fill. The Northern CSR ethos is clearly not relevant to the societal contexts in the emerging and developing economies. These nations often share certain features such as sharp socioeconomic inequalities, deep poverty and discrimination against low-income populations (particularly ethnic minorities), complex resource disputes with many stakeholders, and weak local governance capacity, reflected as severe deficiencies in public services. Governments, in turn, provide lavish benefits for international investments, while at the same time halfheartedly enforcing laws and regulations, and lacking proper CSR standards. These conditions offer MNCs a very flexible environment in which to operate but often impede local livelihoods. When traditional communities face radical changes in their living environments and attempt to adapt to new conditions, we can discuss 'livelihood resilience'. Due to rural communities' vulnerable judicial and socioeconomic positions, firms have an even greater responsibility, although they are very selec- 
Table 2. The basic elements of the CSR Roadmap model (source: the author)

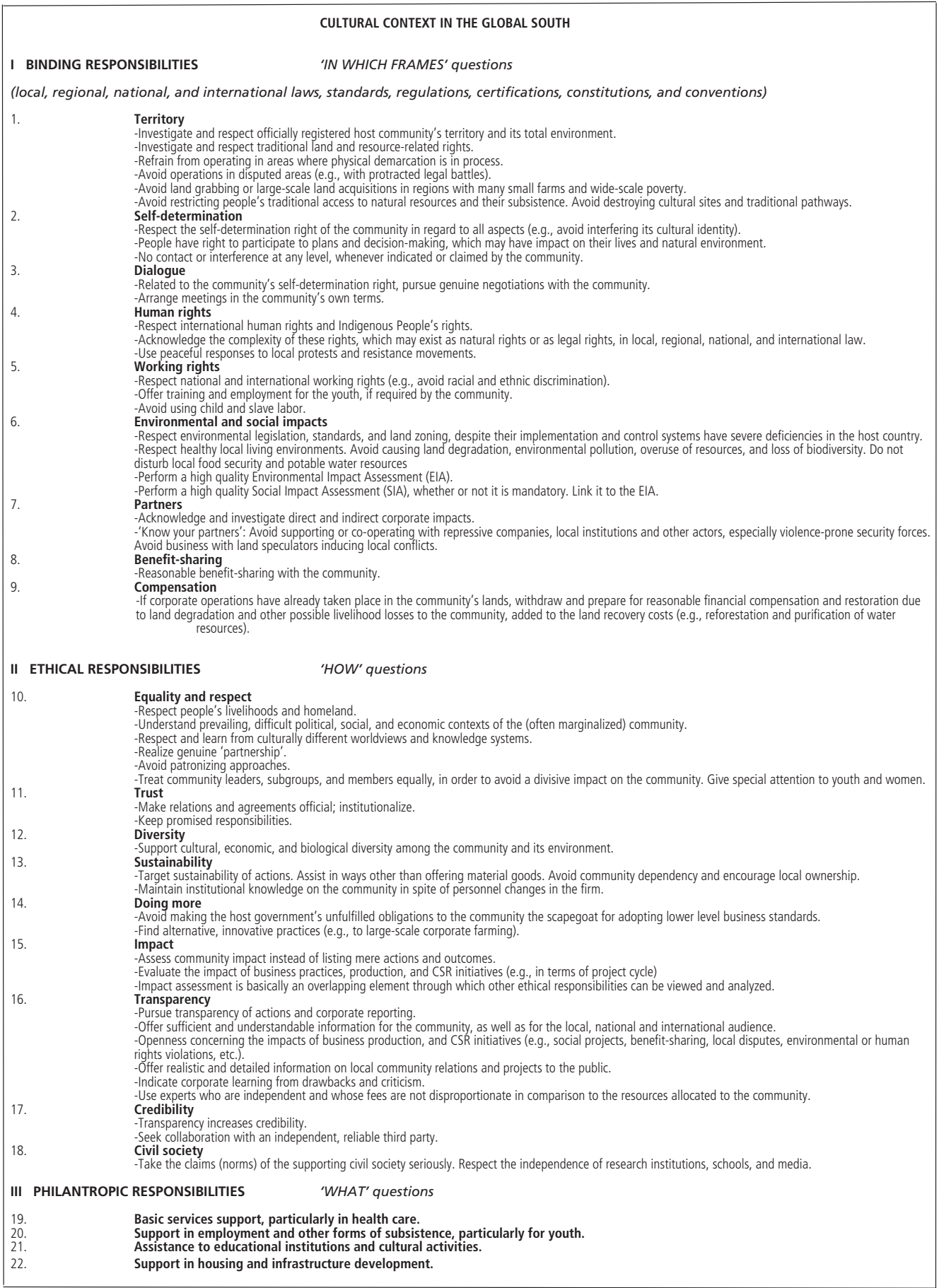


tive in which role they want to adopt when functioning as a significant societal or development agent. Moreover, there is a demand for a better culture-specific understanding of CSR. All this implies the need to obtain more bottom-up knowledge by incorporating fieldwork research practice in business ethics to a greater extent. Nevertheless, collecting in-depth, primary data on the viewpoints of the stakeholders at a grassroots level is rare in the field of business ethics. Despite the emerging new contexts in CSR discourses, little research has been done to connect business ethics with development studies - and especially development ethics - approaches. Yet this linkage is necessary when studying business ethics and local stakeholder relations in the contexts of the global South.

This article finds that firms can be considered responsible not only for their production impact, but also for the CSR performance per se, since its impact may not be always positive. Corporate philanthropy is usually considered a central CSR tool, and it is discussed rather uncritically in the bulk of the CSR literature. However, my data illustrates many problems entailed in philanthropic endeavors, regardless of whether it was a question of money, materials, or programs. Even though philanthropy is tending towards more expert-based assistance, for instance, it requires special capacities to work with local stakeholders, which, in turn, calls for third parties to step in. What is clearly emerging is that MNCs take on, and are expected to take on, various roles of the public sector, so firms have increasingly become 'gap-fillers' for the public sector in the nations struggling with governance crises or otherwise allocating too little resources to the sector. Some authors regard CSR as a positive development agent in countries "governed by weak or predatory states", where corporations may be more capable of delivering development than governments (see Rajak, 2011). On the other hand, the gap-filler situation also creates dependency on corporations and allows local governments to continue to evade their responsibilities. The actual end result may be that CSR supports bad governance structures. Corporate phi-

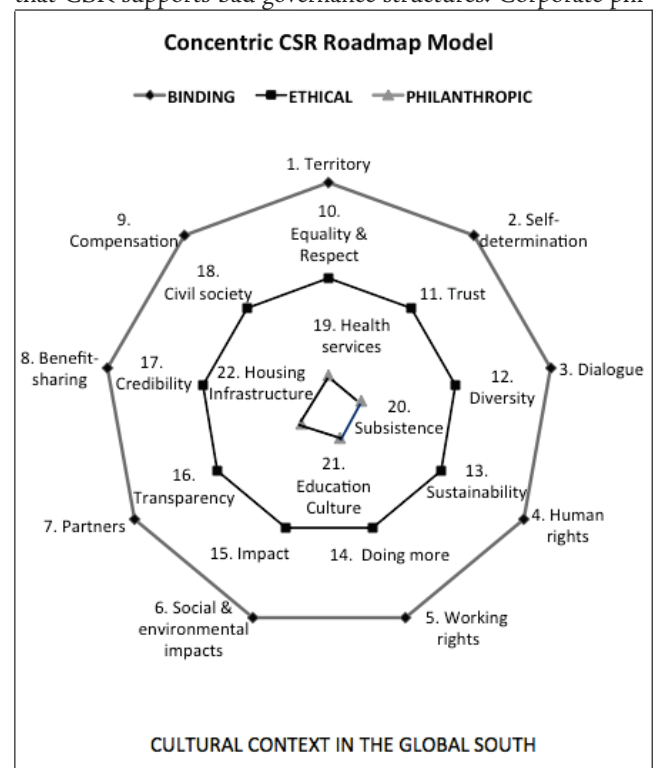

lanthropy is not closely scrutinized nor controlled: accordingly, the CSR field constitutes a gray, 'informal' sector in Southern societies.

In the global South, companies face considerable challenges in identifying and managing the stakeholder arena and heterogeneity within it. The term 'stakeholder' itself has a corporate 'top-down' or even Eurocentric ethos that has been challenged by the grassroots movements. Despite usually being treated as 'extremely external' stakeholders, the Indigenous Peoples and their movements can actually become powerful actors when networking with other national and international movements and publicizing their own agenda in global social media.

Philanthropic activities may have diverse and even contradictory impacts on local communities, in terms of ownership, equality, sustainability, and transparency. Donations of material and other benefits are problematic if they do not serve the larger community. As unintentional or intentional corporate tactics (known as 'guided inclusion'), firms can favor certain groups while excluding others, particularly when the latter criticize the company. Philanthropy is thus likely to create dependency and tensions among the community members, if the aspects of equality and local culture are not properly taken into account. These situations are familiar in international development projects, whose experiences can show the way in developing the CSR field. The lopsided business production impacts, and CSR activities of an MNC, can divide local communities, and even at the micro- or family level, since people possess diverse interests and expectations vis-à-vis the company. In order to calm local resistance and related incidents - actually indicating a serious mismanagement of local relations - companies tend to increase philanthropic assistance, but without solving the underlying problems that spark social unrest and resistance against the company. If the most critical questions, such as land titles, are not resolved, companies appear simply to be buying local acceptability. Thus philanthropy runs a considerable risk or dilemma of engaging in corporate social irresponsibility (CSI) actions in the global South.

My aim was to create a CSR model that reflects common societal circumstances of the emerging and developing economies, and consequently, to present relevant CSR principles. However, the model can be adapted to national contexts, and it is also targeted for other primary and secondary industries dealing with natural resources and local stakeholder relations. By combining the GT approach with a case study, a three-dimensional, Concentric CSR 'Roadmap' Model was developed for corporate-community stakeholder relations. Furthermore, the purpose of the model was to deconstruct the ambiguous CSR concept, and to contribute to the disciplinary bridge-building both theoretically and methodologically between business ethics and development studies, by offering the values of ordinary people. A roadmap is meant to assist in navigating unknown terrain; here its purpose is to help firms pursue more relevant CSR actions and to offer standards for corporate performance assessment in the global South. But the model is equally aimed at providing protection for local communities encountering powerful firms in their backyards. Moreover, the responsibilities should be understood hierarchically in relation to each other - an observation that emerged during my fieldwork. The model states that philanthropy should not be used as a CSR strategy when initially approaching local stakeholders. In other words, firms should not have direct access to the 'core' of the communities, that is, to impact their internal dynamics, culture

Figure 1. Concentric CSR Roadmap model for local community stakeholder relations in the global South (source: the author). 
and development; instead, judicial and other binding issues ought to be tackled first. In addition, the model directs how to plan and execute philanthropic activities so that ethical aspects are also considered. And as the corporations start to operate as gap-fillers, it requires more fundamental public-private debates, and clarification of roles and responsibilities. The Concentric CSR Roadmap Model can be used as a mainstreaming code of conduct to guide and assess corporate performance in local community stakeholder relations. The model also indicates the need to adopt new 'bottom-up' approaches in data collection in business ethics research concerning the global South.

Veracel's case epitomizes a business-as-usual approach, where the company has simultaneously operated in all three CSR levels, and in a very perfunctory manner. Before binding issues were tackled, the company started to offer financial and other support to certain Pataxó villages. The company has not been active in solving land dispute cases in the Indigenous territory. Veracel's stakeholder approach has targeted the host community in a biased, divisive manner, leading to social disintegration. The company has contributed to the congestion of the Indigenous population in urban centers by reducing local livelihoods and has sparked land-based conflicts between local actors. Nor has the company employed the Indians. Furthermore, Veracel has turned itself into a nature-protection authority in the region. The Indigenous schools have received modest assistance, but this type of philanthropy is an example of a societal gap-filler phenomenon and may strengthen corporate dependency in the long term. Sustainability and equality aspects in the community-level projects were ambiguous, and there was no more detailed information available. What is also notable is that Veracel has increased philanthropic assistance after the Indigenous protests, even though Indigenous demands were about resolving disputes over land areas. Overall assistance to the Pataxó communities was minimal in regard to huge financial profits that Veracel produced in the region. It can be questioned whether the 'partnership' (which became a CSR mantra in the Indigenous-corporate relationship) and the entire basis of Veracel's CSR approach were plausible, due to considerable asymmetry in power relations and unresolved Indigenous needs. Basically, the company aimed at compensating the contested parts of the Indigenous territory and its livelihood losses with 'a package of books', as one chief stated. The stakeholders were not involved in the business decision-making on the more equitable benefits, but neither did they claim this, except concerning the land issue. On the contrary, the Pataxó were afraid to lose even the small benefits. In conclusion, Veracel has violated many of the Indigenous Peoples' rights recognized in the Brazilian Constitution and international conventions.

One of the aims of this research was to assess to what extent corporate words were compatible with corporate actions concerning the CSR initiatives and the stakeholder relationships. Veracel's partner firms Stora Enso and Fibria/Aracruz were also included in the analysis of corporate reports. There were signs that the companies were interested in improving their stakeholder relations. These were described in varying ways and lengths in the reports, and some of them were verified in my study. Nevertheless, the CSR actions and stakeholder relationships were portrayed as more active and trouble-free than they were in reality. Overall, the reports exposed a tendency to either prettify or keep silent about the situations, so the presented facts were selective. One worrisome trend is to quote local villagers praising the company, or exposing their personal stories. Another is to publish pictures of the Indigenous and other (traditional) communities' members. Using and publish- ing photos of the children and youth is particularly unethical not to mention that the context is about 'responsible business'. Hence the corporate reports lack, above all, judgment capacity at the management level. 'Sustainability' is an ambiguous concept for corporate reports, since they deal very little with actual sustainable development, as the term entails an idea of positive, long-term impact, but its local application is far from clear in the reports. The implemented CSR measures were listed, but their impact on the stakeholders was not assessed or mentioned. It follows that the prevalent 'storyteller's style' - whether in producing reports, offering public statements, and innovating brand-uplifting projects in social media - is advantageous for the company. Stora Enso's Global Responsibility Web site was given the European Excellence Award in 2010, even though the site omits mention of the main problems with the Indigenous groups or the landless rural peasants in Bahia. In the worst cases, companies that violate human rights or environmental laws in the global South are simultaneously rewarded by national and international CSR institutions and/or participate in initiatives such as Global Compact. Hence information from the stakeholder level does not reach these types of global institutions. Furthermore, a global corporation's CSR performance should be thoroughly credible, implying that there are no significant discrepancies when comparing countries.

Unethical practices in business communications not only bring into question the ethics within the corporate management level per se but also undermine the credibility of the rest of the business. If one or two parts of the picture do not correspond to reality, what else may have been omitted? Do we want only positive stories and news, and whom do they ultimately serve? A realistic account of business performance available to shareholders, including governments, is a minimum prerequisite for the follow-up of risky situations when there are important economic, judicial or brand issues at stake. For instance, according to Stora Enso's Web site, the company is committed "to give adequate information to minimize the investor's risk". The wider public, including the taxpayers, also deserves better information about where and how their money is being spent, and what kind of consequences the investments and their financial support system have in the global South. And last but not least, reports and other necessary information should be available to the stakeholders in their own language.

This article has focused on the Indigenous-corporate relationship in the Brazilian context, which well illustrates the CSR problematic in other, rapidly industrializing regions. The legal basis directing the role and impacts of MNCs is very ambiguous. My study found that not only business production but also CSR practices are inclined to bring about wide-ranging and unseen, problematic societal impacts, which could be avoided by adopting more accurate, binding and enforceable codes of conduct. This article opens up a new agenda for work on CSR with Southern societies and their local communities.

\section{Endnotes}

1 International consulting and engineering company Pöyry produced a range of feasibility studies and an environmental impact assessment. Metso Automation (a subsidiary of the Finnish Metso Corporation) won a US\$7 million order to supply valves and online analyzers; Partek Forest (Finland) won a US\$25 million contract, its largest ever, to deliver harvesting equipment to Aracruz and Veracel. Pöyry's Brazilian subsidiary Jaakko Pöyry Tecnologia Ltd. subsequently won US\$16 million in engineering contracts on the construction of the Ve- 
racel pulp mill. (Lang 2008, 31-32.)

2 It is mandatory for firms to protect 20 percent of their land area in Brazil. Veracel Station protects over 6,000 hectares of Atlantic rainforest. According to a nature-survey specialist, Juha Honkala of the Finnish Museum of Natural History,

\section{References}

Astroulakis, N. (2013), "Ethics and international development: The development ethics paradigm", Journal of Economics and Business, Vol.16 No. 1, pp. 99-117.

Banerjee, S.B. (2008), "Corporate social responsibility: The good, the bad, and the ugly", Critical Sociology, Vol. 34 No 1, pp. 51-79.

Biller, D. (1998), Environmental impact assessment: The Brazilian experience. The World Management Portfolio Review, Environment Papers No. 58, The World Bank.

Brønn, P. and Vidaver-Cohen, D. (2009), "Corporate motives for socia initiative: Legitimacy, sustainability, or the bottom line?" Journal of Business Ethics, Vol. 87, pp. 91-109.

Bruijin, E. and Whiteman, G. (2010), "That which doesn't break us: Identity work by local Indigenous 'stakeholders', Journal of Business Ethics, Vol. 96, pp. 479-495.

Carneiro, M.S. (2008), Crítica social e responsabilizaçáo empresarial. Análise das estratégias para a legitimação da produçáo siderúrgicana na Amazonia oriental, CADERNO CRH, Salvador, Brazil, Vol. 21 No. 53, pp. 323-336.

Carroll, A.B. (1991), The pyramid of corporate social responsibility: Toward the moral management of organizational stakeholders, Business Horizons, July-August.

Carvalho, R.M. de (2009), “O Monte Pascoal, os Índios Pataxó e a luta pelo reconhecimento étnico", CADERNO CRH, Salvador, Brazil, Vol. 22 No. 57, pp. 507-521.

Chambers, R. (1997), Whose reality counts? Putting the first last, Intermediate Technology Publications, London.

Clark, D.A. (2002), "Development ethics: a research agenda", International Journal of Social Economics, Vol. 29 No. 11, pp 830-848.

Crawley, A. and Sinclair, A. (2003), "Indigenous human resource practices in Australian mining companies: Towards an ethical model", Journal of Business Ethics Vol. 45, pp. 361-373.

Crocker, D.A. (1998), "International development ethics", Twentieth World Congress of Philosophy, Boston, Massachusetts, August 10-15. Available http://www.bu.edu/wcp/Papers/OApp/ OAppCroc.htm

Crocker, D.A. (2008), Ethics of global development: Agency, capability, and deliberative democracy, Cambridge University Press, Cambridge.

Crooks, D.L. (2001), "The importance of symbolic interaction in grounded theory research on women's health", Health Care for Women International, Vol. 22, pp. 11-27.

Dunham, L., Freeman, R.E., and Liedtka, J. (2006), “Enhancing stakeholder practice: A particularized exploration of community", Business Ethics Quarterly, Vol. 16 No. 1, pp. 23-42

Escobar, A. (1995), Encountering development: The making and unmaking of the Third World, Princeton University Press, Princeton.

Eweje, G. (2007), “Multinational oil companies' CSR initiatives in Nigeria. The scepticism of stakeholders in host communities", Managerial Law, Vol. 49 No. 5/6, pp. 218-235.

Fernández, W.D. (2004), "The grounded theory method and case study data in IS research: issues and design", Paper presented at the Information Systems Foundations Workshop: Constructing and
Veracel Station has high-quality lowland forest, inhabited by rare bird species. Bahia is often regarded as a severely deforested region that is less important in terms of biodiversity. However, large intact mountain forests with recently discovered animal species can be found there. (Honkala, personal communication, 2010.)

Criticising, Canberra, Australia. Available http://epress.anu.edu.au/ info_systems/part-ch05.pdf

Ferreira, S. R. B., Gonçalves, A. C., Machado S. L., Maracci, M. T.

Mazzeto, C. E., Rocha, L. C., Sampaio, J. A. L., and Santos, M. L. F. (2010), Estudo etnoambiental Terra Indigena Tupiniquim e Terra Indígena Comboios, Anaí-BA, 3 volumes, Salvador, Brazil.

Fibria Sustainability Report 2011. Available http://www.fibria.com.br/ rs2011/Fibria_2011_Sustainability_Report.pdf

Freeman, R. E. (1984), Strategic Management: A stakeholder approach, Pitnam, Boston.

Frynas, J.G.(2005), "The false developmental promise of Corporate Social Responsibility: Evidence from multinational oil companies", International Affairs, Vol. 81 No. 3, pp. 581-598.

Global Reporting Initiative. Available https://www.globalreporting. org/

Goulet, D. (1996), “Authentic development: Is it sustainable?” In Pirages, D. C. (Ed.), Building sustainable societies, M.E. Sharpe, New York, pp. 189-205.

Goulet, D. (1997), "Development ethics: a new discipline”, International Journal of Social Economics, Vol. 24, No. 11, pp. 1160-1171.

Haller, T., Blochlinger, A., John, M., Marthaler, E., and Ziegler, S. (Eds.). (2007). Fossil, fuels, oil companies and Indigenous Peoples. Strategies of multinational oil companies, states, and ethnic minorities. Impact on environment and, livelihoods, and cultural change, Transaction Publishers, New Brunswick, Canada.

Hamann, R. and Kapelus, P. (2004), "Corporate social responsibility in mining in Southern Africa: Fair accountability or just greenwash?" Development, Vol. 47, No. 3, pp. 85-92.

Hess, D., Rogobsky, N. and Dunfee, T.W. (2002) “The next wave of corporate community involvement: Corporate social initiatives", California Management Review, Vol. 44, No. 2, pp. 110-125.

Hofstede, G., Hofstede, G.J., Minkov, M. (2010), Cultures and Organizations: Software of the Mind, 3rd Edition, McGraw-Hill, USA.

Husted, B. and Allen, D. B. (2006), "Corporate social responsibility in the multinational enterprise: strategic and institutional approaches", Journal of International Business Studies, Vol. 37, pp. 838-849.

Hyndman, D. (1988), "Melanesian resistance to ecocide and ethnocide: Transnational mining projects and the Fourth World on the island of New Guinea", in Bodley, J. (Ed.), Tribal Peoples and Development Issues. A Global Overview, Mayfield Publishing Company, Mountain view, CA, pp. 281-298.

Idahosa, P. (2002), "Business ethics and development in conflict (zones): The case of talisman oil", Journal of Business Ethics, Vol. 39, pp 227-246.

International Labor Organization (ILO). Available http://www.lo. org/indigenous/Conventions/no169/lang--en/index.htm

International Work Group for Indigenous Affairs (IWGIA). Available http://www.iwgia.org/culture-and-identity/identification-ofindigenous-peoples

Jenkins, H. and Obara, L. (2008), “Corporate Social Responsibility (CSR) in the mining industry - the risk of community dependency", CRRC 2008 Conference 7-9 September 2008,

Queen's University Belfast, available http://www.crrconference.org/ 
downloads/2006jenkinsobara.pdf

Jones, R., Bowd, R. and Tench, R. (2009), "Corporate irresponsibility and corporate social responsibility: competing realities", Social Responsibility Journal, Vol. 5, No. 3, pp. 300-310.

Kapelus, P. (2002), "Mining, corporate social responsibility and the "community": The case of Rio Tinto, Richards Bay Minerals and the Mbonambi", Journal of Business Ethics, Vol. 39, pp. 275-296.

Kirchhoff, D. (2006), "Capacity building for EIA in Brazil: Preliminary considerations and problems to be overcome", Journal of Environmental Assessment Policy and Management, Vol. 8, No. 1 pp. 1-18.

Kotchen, M.J. and Moon, J.J. (2011), Corporate social responsibility for irresponsibility, Working Paper 17254, National Bureau of Economic Research, Cambridge, MA.

Kröger, M. and Nylund, J-E. (2011), "The conflict over Veracel pulpwood plantations in Brazil - application of ethical analysis", Forest Policy and Economics, Vol. 14 No. 1, pp. 74-82.

Lertzman, D.A. and Vredenburg, H. (2005), "Indigenous peoples, resource extraction and sustainable development: An ethical approach", Journal of Business Ethics, Vol. 56, pp. 239-254

Murphy, M. and Arenas, D. (2010), “Through Indigenous lenses: Cross-sector collaborations with fringe stakeholders", Journal of Business Ethics, Vol. 94, pp. 103-121.

Myllylä, S. (1998.), "Development for whom? From Opportunist NGOs to People's Organiza-tions", in Hossain, F. and Myllylä, S. (Eds.), NGOs under challenge. Dynamics and drawbacks in develop $\urcorner$ ment, The Ministry for Foreign Affairs of Finland, Dept. for Interna 7 tional Development Cooperation, Helsinki, pp. 47-59.

Myllylä, S. (2010), "Ethnoterritoriality confronting multinationals: Indigenous Peoples' perceptions on eucalyptus plantation industries in Atlantic Coastal Brazil", Arctic \& Antarctic. International Journal of Circumpolar Sociocultural Issues, Vol. 4 No. 4, pp. 97-145.

Myllylä, S. and Takala, T., (2011), “Leaking legitimacies: The Finnish forest sector's entanglement in the land conflicts of Atlantic coastal Brazil", Social Responsibility Journal, Vol. No. 1, pp. $42-60$.

Pires, C. (2011), "Statute of Indigenous Peoples shelved by Congress", available http://infosurhoy.com/cocoon/saii/xhtml/en_GB/ features/saii/features/main/2011/07/21/feature-03

Povos Indígenas no Brasil, available http://pib.socioambiental.org/ en/c/terras-indigenas/introducao/o-que-sao-terras-indigenas

Rajak, D. (2011), In good company: An anatomy of Corporate Social Responsibility, Stanford University Press, Stanford.

Reed, D. (2002) "Introduction", Journal of Business Ethics, Vol. 39, pp. 199-226.

Reuveny, R.X. and Thompson, W.R. (2007), “The North-South divide and international studies: A Symposium", Studies Review, Vol. 9 No. 4, pp. 556-564

Sagebien, J.and Whellams, M. (2010), "CSR and development: Seeing the forest for the trees. Canadian Journal of Development Studies", Vol. 31, No. 3-4, pp. 483-510.

Sawyer, S. and Gomez, E.T. (2008), "Transnational governmentality and resource extraction. Indigenous Peoples, Multinational Corporations, Multilateral Institutions and the State", Identities, Conflict and Cohesion Programme Paper, No 13. UNRISD, Geneva.

Seton, K. (1999), "Fourth World Nations in the era of globalisation: An Introduction to contemporary theorizing posed by Indigenous nations", Fourth World Journal, Vol. 4 No. 1, Center for World Indigenous Studies, Washington, available http://nointervention. com/archive/pubs/CWIS/fworld.html

Stora Enso (2012), Rethink. People and Purpose, Vol. 3.

Stora Enso Global Responsibility Report 2012. Available http:// www.storaenso.com/media-centre/publications/annualreport/Documents/Stora_Enso_E_Global_Responsibility_
Report_2012.pdf

Strauss, A. and Corbin, J. (1990), Basics of qualitative research. Grounded theory procedures and techniques, Sage Publication, London.

United Nations' Declaration on the Rights of Indigenous Peoples (2008), available http://www.un.org/esa/socdev/unpfii/ documents/DRIPS_en.pdf

United Nations General Assembly (2012), "The report of the Special Rapporteur on the rights of indigenous peoples", available http:// daccess-dds-ny.un.org/doc/UNDOC/GEN/G12/162/70/PDF/ G1216270.pdf?OpenElement

United Nations Global Compact, available http://www. unglobalcompact.org/About TheGC/index.html

United Nations Global Compact, Communication on progress (2011), available http://unglobalcompact.org/participants/expelled/9934Veracel-Celulose-S-A.

Urquhart, C. (2001), "An encounter with Grounded Theory: Tackling the practical and philosophical issues", in Trauth, E. (Ed.), Qualitative research in information systems: Issues and Trends, Idea Group Publishing, London, pp. 104-140.

Urquhart, C. and Fernandez, W. (2006), "Grounded Theory method: The researcher as blank slate and other myths", in Straub, D. and Klein, S. (Eds.), Proceedings of the Twenty Seventh International Conference on Information Systems, Milwaukee, US, pp. 457-464

Velame, F. (2010), "KIJEMES: Arquiteturas Indígenas Pataxós da Resistência ao Espetáculo", in VI ENECULT: Encontro Nacional de Estudos Multidisciplinares em Cultura, Salvador, Brazil.

Veracel Celulose Sustainability Report 2010, available http://www. veracel.com.br $/$ LinkClick.aspx?fileticket $=92 \mathrm{FlaYPBHyI} \% 3 \mathrm{D} \&$ tabi $\mathrm{d}=151 \& \mathrm{mid}=1020$

Veracel Celulose Sustainability Report 2011, available http://www. veracel.com.br/LinkClick.aspx?fileticket=lvm8_4YZIVU\%3D\&ta bid $=1518 \mathrm{mid}=1020$

Veracel Celulose Sustainability Report 2012, available http:// www.veracel.com.br/LinkClick.aspx?fileticket $=Q q 4 p n 1 q$ Szc\%3d\&tabid $=1512 \mathrm{mid}=1020$

Veracel News (2011), "Indigenous students receive support back to school", 14 February, available http://www.veracel.com.br/en/ Press $/$ News.aspx?idNoticia $=84$

Vintró, C. and Comajuncosa, J. (2010), “Corporate social responsibility in the mining industry: Criteria and indicators", Dyna, Vol. $77 \mathrm{No}$ 161, pp. 31-41, Universidad Nacional de Colombia.

Walton, S. (2007), "Site the mine in our backyard! Discursive strategies of community stakeholders in an environmental conflict in New Zealand", Organization \& Environment

Vol. 20, pp. 177-204

Wheeler, D., Fabig, H. and Boele, R. (2002), "Paradoxes and dilemmas for stakeholder responsive firms in the extractive sector: Lessons from the case of Shell and the Ogoni", Journal of Business Ethics, Vol.39, pp. 297-318.

Whiteman, G. (2009), "All my relations: Understanding perceptions of justice and conflict between companies and Indigenous Peoples", Organization Studies, Vol. 30 No. 1, pp. 101-120.

Whiteman, G. and Cooper, W.H. (2000), "Ecological embeddedness", The Academy of Management Journal, Vol. 43 No. 6, pp. 1265 1282.

Yaacob, M.R. and Wong, L. (2007), “Stakeholders' activisms: Indigenous peoples' of Sarawak resistance against the state government and corporations", Social Responsibility Journal, Vol. 3 No. 2, pp. 39-51.

Yakovleva, N. and Vazquez-Brust, D. (2012), "Stakeholder perspectives on CSR of mining MNCs in Argentina", Journal of Business Ethics, Vol. 106, pp. 191-211. 


\section{Author}

Susanna Myllylä is currently working as a university researcher at the department of History and Ethnology in the University of Jyväskylä. She is also a member in the Responsible Leadership and Management (RELM) group at the Jyväskylä University School of Business and Economics. Myllylä has a PhD in administrative sciences (regional studies) from the University of Tampere. She has long-term experience in the field of development studies, for instance, in sustainable development, local livelihoods in urban and rural contexts, and new social movements. She has carried out extensive fieldwork in Brazil, Egypt, India, and Tanzania. In addition, she has worked as an evaluator in international development programs.

Contact email: susanna.b.myllyla@jyu.fi 